
de ensino de São Paulo: relatos de profissionais especializados 


\section{A inclusão de alunos com surdocegueira na rede municipal de ensino de São Paulo: relatos de profissionais especializados}

\section{Versão corrigida}

Dissertação de Mestrado apresentada ao Programa de Pós-Graduação do Instituto de Psicologia da Universidade de São Paulo para obtenção do título de Mestre em Psicologia

Área de Concentração: Psicologia Escolar e do Desenvolvimento $\mathrm{Hu}-$ mano (PSA)

Orientador: Prof. Dr. Lineu Norio Kohatsu 
AUTORIZO A REPRODUÇÃO E DIVULGAÇÃO TOTAL OU PARCIAL DESTE TRABALHO, POR QUALQUER MEIO CONVENCIONAL OU ELETRÔNICO, PARA FINS DE ESTUDO E PESQUISA, DESDE QUE CITADA A FONTE.

Catalogação na publicação

Biblioteca Dante Moreira Leite

Instituto de Psicologia da Universidade de São Paulo

\section{Emi, Lia Cazumi Yokoyama.}

A inclusão de alunos com surdocegueira na rede municipal de ensino de São Paulo: relatos de profissionais especializados / Lia Cazumi Yokoyama Emi; orientador Lineu Norio Kohatsu. -- São Paulo, 2017.

$163 \mathrm{f}$.

Dissertação (Mestrado - Programa de Pós-Graduação em Psicologia. Área de Concentração: Psicologia da Aprendizagem, do Desenvolvimento e da Personalidade) - Instituto de Psicologia da Universidade de São Paulo.

1. Surdocegueira 2. Educação inclusiva 3. História oral I. Título. 
Nome: EMI, Lia Cazumi Yokoyama

Título: A inclusão de alunos com surdocegueira na rede municipal de ensino de São Paulo: relatos de profissionais especializados

Dissertação apresentada ao Programa de Pós-Graduação do Instituto de Psicologia da Universidade de São Paulo para obtenção do título de Mestre em Psicologia

Aprovado em:

Banca Examinadora

Prof. Dr.

Instituição:

Julgamento:

Assinatura:

Prof. Dr.

Instituição:

Julgamento:

Assinatura:

Prof. Dr.

Instituição:

Julgamento:

Assinatura: 
Para Adalberto, por dar sustento à minha alma

Para TYS, in memorian 


\section{AGRADECIMENTOS}

Ao Prof. Dr. Lineu Norio Kohatsu, pela orientação absolutamente generosa e cuidadosa, pelos diálogos inspiradores e pelas correções sempre pertinentes e necessárias.

Às profissionais da Rede Municipal de Ensino, que colaboraram voluntariamente com esta pesquisa, compartilhando suas histórias, conhecimento e experiências, aqui identificadas como Sara, Lídia, Ester e Rute.

Às Prof. Dr. Marian Ávila de Lima Dias e Prof. Dr. Shirley Rodrigues Maia, pelas importantes contribuições durante o exame de qualificação. Todas as sugestões, observações, correções e apontamentos foram de grande valia para a finalização desta pesquisa.

Às minhas colegas de orientação, Adriana e Denise, pelas trocas a cada reunião. Em especial à Denise, por nos guiar em meio aos complexos caminhos da Plataforma Brasil.

Ao Instituto de Psicologia, por acolher uma historiadora.

Aos professores das disciplinas cursadas durante a pós-graduação: Adriana Marcondes Machado, Christina Joselevitch, Daniela Maria Oliveira Bonci, Dorothy Fragaszy, José Leon Crochík, José Sérgio Fonseca de Carvalho, Maria Isabel da Silva Leme, Maria Luisa Sandoval Schmidt, Marie Claire Sekkel e Mirella Gualtieri. Todos proporcionaram espaços para inúmeras discussões e compartilhamentos necessários

À Rosângela, que de colega, passou a ocupar um lugar de amiga e orientadora da vida!

Ao Alexsandro, professor que levo como guia-companhia em minhas reflexões.

À Sueli, por todas as conversas, que sempre provocam desconforto... porque pensar nunca é fácil.

À Sophia, pela leitura atenta do relatório de qualificação e pela parceria em nossos projetos historiográficos.

À Suzana, pelas importantes considerações relacionadas ao método e às discussões da História Oral. 
A todas as pessoas da Comunidade Surda com quem convivi e que me fizeram compreender a importância da Cultura Surda.

Aos meus tutores do curso de formação de Guias-intérpretes, em especial à Cláudia Sofia, ao Carlos Jorge e à Shirlei.

À Prof. Dr. Carla Biancha Angelucci, sempre disposta a estender a mão.

À Maria Nina Cormedi, que também deixou fortes alicerces para que eu pudesse traçar este caminho.

Aos meus alunos e alunas da UnYLeYa, que tornaram tantas outras leituras e discussões necessárias.

A tod@s da 32ª Bienal de São Paulo: Diran, Janaína, Flávio, Daiana, Rocío, Renato, Bruno, Cláudia, Carina, T(h)iagos, Lívia, Lucimara... impossível listar tod@s que alimentaram minhas reflexões enquanto eu escrevia este trabalho. Nossas conversas estão nas entrelinhas deste texto!

A toda minha família, que ocupa meu coração, em especial aos meus pais, que abdicaram de tantas coisas para me garantir tantos privilégios e facilidades, e à Emy, que desde a infância vem chamando minha atenção para as questões sociais e para as injustiças no mundo.

Ao Adalberto, pois a realização desta pesquisa não teria sido possível sem o seu suporte, principalmente emocional, regado de muita paciência. Companheiro, que há mais de duas décadas guia minha presença no mundo, sempre com muito bom humor e um cuidado especial. Todos os dias são plenos ao seu lado, e este trabalho, construímos juntos, como todas as demais conquistas que amealhamos, dia após dia.

Por fim, gostaria de deixar uma homenagem saudosa aos professores do Departamento de História da FFLCH-USP, que já nos deixaram, mas que plantaram sementinhas para várias reflexões teóricas presentes neste trabalho. Augustin Wernet, István Jancsó e Nicolau Sevcenko, gratidão e admiração. 


\author{
A Perfeição \\ O que me tranquiliza \\ é que tudo o que existe, \\ existe com uma precisão absoluta. \\ O que for do tamanho de uma cabeça de alfinete \\ não transborda nem uma fração de um milímetro \\ além do tamanho de uma cabeça de alfinete. \\ Tudo o que existe é de uma grande exatidão. \\ Pena é que a maior parte do que existe \\ com essa exatidão \\ nos é tecnicamente invisível. \\ O bom é que a verdade chega a nós \\ como um sentido secreto das coisas. \\ Nós terminamos adivinhando, confusos, \\ a perfeição.
}

Clarice Lispector 


\title{
RESUMO
}

\author{
EMI, L. C. Y. A inclusão de alunos com surdocegueira na rede municipal de ensino de São \\ Paulo: relatos de profissionais especializados. 2017. 163 f. Dissertação (Mestrado) - Instituto \\ de Psicologia, Universidade de São Paulo, São Paulo, 2017.
}

A presente dissertação tem como objetivo geral propiciar uma reflexão sobre as mudanças na educação a partir do olhar de profissionais especializados da Rede Municipal de Ensino de São Paulo que atuaram na inclusão de alunos com surdocegueira. Os objetivos específicos eram: pontuar elementos das histórias de vida das colaboradoras que participaram da pesquisa e sobre a sua atuação profissional, principalmente na EMEBS; problematizar as escolhas e ações durante o exercício de sua profissão, visando compreender seu olhar sobre o objetivo da educação; analisar os relatos dessas profissionais sobre as mudanças metodológicas, buscando reunir informações sobre esse processo. As questões que nortearam o estudo foram: Como se deu a chegada de alunos com surdocegueira nessas unidades? O que essa chegada causa nos professores especialistas? Como compreender a educação especial em uma perspectiva inclusiva, frente a uma escola bilíngue para Surdos? Qual o papel dos profissionais envolvidos nesse processo e qual a relevância de um espaço especializado? Optou-se pela abordagem qualitativa e as fontes primárias para a realização da pesquisa foram as histórias de vida de quatro colaboradoras, todas mulheres, todas da mesma unidade educacional. A coleta foi feita por meio de entrevistas orais e os critérios utilizados para a escolha das participantes foram: profissionais que atuassem ou tivessem atuado nas EMEBS; que soubessem Libras; que tivessem atuado direta ou indiretamente na inclusão de alunos com surdocegueira nessas unidades; e que tivessem interesse em contribuir, voluntariamente, com o estudo. Após da realização das entrevistas, todo o material em áudio foi transcrito, mas apenas parte das informações foram utilizadas em uma discussão que teve como base teórica as obras de Arendt, Adorno e Horkheimer. Foi possível propor e aprofundar algumas reflexões sobre a educação a partir da inclusão de alunos com surdocegueira. Pudemos constatar que a chegada desses alunos provocou, em um primeiro momento, resistência por parte de alguns profissionais. Entretanto, ações coletivas garantiram a entrada e a permanência desses alunos, com qualidade, na rede municipal de ensino. As reflexões seguiram duas categorias de análise: a concepção de educação dessas profissionais especializadas e a questão de como a ideia de "normalidade" comparece na EMEBS. Foi possível propor palavras-síntese para representar o olhar dessas educadoras: direito, acolhimento, respeito e responsabilidade. A soma desses diferentes olhares propiciou a inclusão, libertando esta palavra de sua origem etimológica, que remete à ideia de clausura. A reestruturação das EMEBS, a opção pelo exercício da profissão na rede pública e as experiências passadas dessas educadoras, favoreceram o estabelecimento de um repertório que permitiu a formulação de respostas novas. Foi possível perceber que a EMEBS é um lugar que tem estabelecido teias de relações, não apenas com outros profissionais da rede municipal de ensino, como também com pessoas da Comunidade Surda e pessoas com surdocegueira adultas, constituindo-se como um espaço bicultural. Essa reflexão passou a apresentar-se como chave para a compreensão da perspectiva inclusiva. Este trabalho também buscou registrar uma versão que se afasta do discurso do fracasso da educação pública.

Palavras-chave: surdocegueira; educação inclusiva; história oral. 


\begin{abstract}
EMI, L. C. Y. The inclusion of students with deafblindness in the municipal school system of São Paulo: specialized professionals narratives. 2017. $163 \mathrm{f}$. Dissertation (Master Degree) - Instituto de Psicologia, Universidade de São Paulo, São Paulo, 2017.
\end{abstract}

The general objective of the present dissertation is to propitiate a reflection on the changes in education from the view of specialized professionals who took part in the process of the inclusion of students with deafblindness in the municipal education network of São Paulo. Its specific goals are to point out the cooperators life history and their professional performance, especially in the EMEBS (Municipal School of Bilingual Education for the Deaf); question their choices and actions as professionals, in order to comprehend how they understand education; analyze their stories on the methodological changes, trying to gather information about this process. The guiding questions of this study were: How do the students with deafblindness get to these educational units? What do their arrival cause in the specialized professionals? How can we understand the special education in an inclusive perspective, facing a bilingual school for the Deaf? What is the involved professionals' role and what's the importance of a specialized space? We've chosen the qualitative approach and the primary sources for the execution of the research were the life histories of four cooperators, all women, all from the same educational unit. The collection was done through oral interviews and the criteria for the selection of the participants were: professionals who work or had worked in the EMEBS; who knew Libras; who had worked directly or indirectly in the inclusion of students with deafblindness in these units; and who had the interest to contribute, voluntarily, with this study. After recording the interviews, all the audio material was transcribed, but only part of the information was used in a discussion that had as a theoretical basis the studies of Arendt, Adorno and Horkheimer. It was possible to propose and to deepen some of the ideas related to the education from the inclusion of students with deafblindness. We could ascertain that the arrival of these students caused, in a first moment, resistance of some of the professionals. However, collective actions guaranteed the entrance and the permanence of these students, with quality, in the municipal education network. The reflections followed two categories of analyses: the notion of education of the specialized professionals and the question of how the idea of "normality" is present in the EMEBS. It was possible to propose some synthesis-words to represent the point of view of these educators: right, welcoming, respect and responsibility. The sum of these different views fostered the inclusion, making this word get free from its etymological origin, that refers to the idea of enclosure. In the very structure of the EMEBS, the option to work as a professional in the public schools, and the past experiences of these educators, promoted the establishment of a repertoire that enabled the shaping of new answers. With the reflections, it was possible to comprehend that the EMEBS are places where a web of relations are being settled, not only with other professionals of the municipal education network, but also with adult people from the Deaf Community and adult persons with deafblindness, arising as a bicultural space. These thoughts became a key for the comprehension of the inclusive perspective. This research aimed to register a version that gets apart from the failure discourse of public education.

Keywords: deafblindness; inclusive education; oral history. 


\section{LISTA DE ABREVIATURAS E SIGLAS}

ADEFAV Centro de Recursos em Deficiência Múltipla, Surdocegueira e Deficiência Visual (anteriormente identificada como Associação para Deficientes da Áudio-Visão)

AHIMSA Associação Educacional para Múltipla Deficiência

ATE Auxiliar Técnico de Educação

AEE Atendimento Educacional Especializado

AEC Atividades de Enriquecimento Curricular

AVE Auxiliares de Vida Escolar

CAEE Centros de Atendimento Educacional Especializado

CEFAI Centros de Formação e Acompanhamento à Inclusão

CEI Centros de Educação Infantil e Creches Conveniadas

CENESP Centro Nacional de Educação Especial

CENTRAU Centro de Atendimento e Reabilitação da Audição

CEP Comitê de Ética em Pesquisa

CONADE Conselho Nacional dos Direitos da Pessoa com Deficiência

Confenen Confederação Nacional dos Estabelecimentos de Ensino

DOT-EE Diretoria de Orientação Técnica-Educação Especial

DOT-P Diretoria de Orientação Técnico Pedagógica

DRE Diretoria Regional de Educação

EDAC Educação do Deficiente da Audiocomunicação

EFAL Estimulação da Fala, Audição e Linguagem

EJA Educação de Jovens e Adultos

EMEBS Escola Municipal de Educação Bilíngue para Surdos

EMEE Escola Municipal de Educação Especial

EMEF Escola Municipal de Ensino Fundamental

EMEI Escola Municipal de Educação Infantil

ERDAV Escola Residencial para Deficientes Auditivos e Visuais

FENEIS Federação Nacional de Educação e Integração de Surdos

FFLCH Faculdade de Filosofia, Letras e Ciências Humanas

FMU Faculdade Metropolitanas Unidas

FUND I Ensino Fundamental I (do primeiro ao quinto ano) 
FUND II Ensino Fundamental II (do sexto ao nono ano)

IDH-D Índice de Desenvolvimento Humano ajustado à Desigualdade

IMT Iniciação ao Mundo do Trabalho

JEIF Jornada Especial Integral de Formação

LDB(EN) Lei de Diretrizes e Bases (da Educação Nacional)

Libras $\quad$ Língua de Sinais Brasileira

NEHO Núcleo de Estudos em História Oral

ONCE Organização Nacional de Cegos da Espanha

PAAI Professor de Apoio e Acompanhamento à Inclusão

PCN Parâmetros Curriculares Nacionais

PDI Plano de Desenvolvimento Individualizado (ou Individual)

PEI Plano Educacional Individualizado

PUC - SP Pontifícia Universidade Católica de São Paulo

RME Rede Municipal de Ensino

SAAI Salas de Apoio e Acompanhamento à Inclusão

SAS Secretaria Municipal de Assistência Social

SME Secretaria Municipal de Educação

SEDAV Setor de Educação de Deficientes Audiovisuais

SEESP Secretaria de Educação Especial

TCLE Termo de Consentimento Livre e Esclarecido

TCUD Termo de Compromisso de Utilização dos Dados

UE Unidade Educacional

ULAC União Latino Americana de Cegos

USP Universidade de São Paulo 


\section{LISTA DE TABELAS}

Tabela I - Nome fictício adotado para cada colaboradora e respectivo cargo (p.56)

Tabela II - Tempo médio de gravação e de conversa com cada colaboradora, listada segundo a sequência de realização das entrevistas (p.58) 


\section{SUMÁRIO}

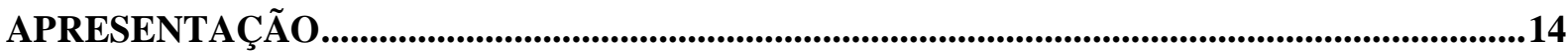

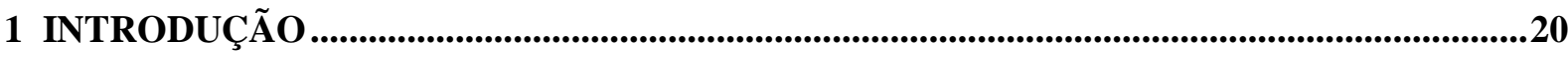

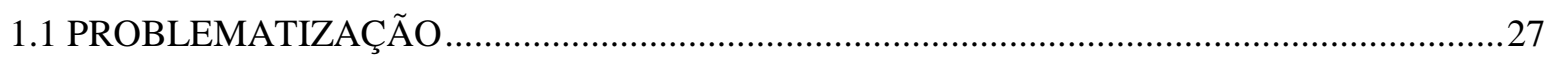

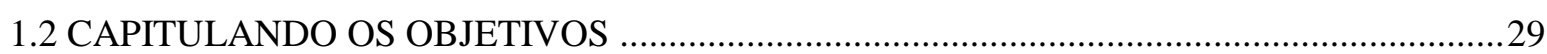

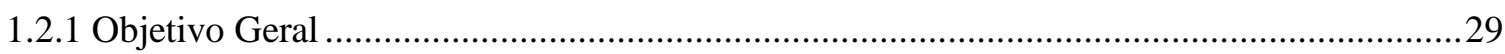

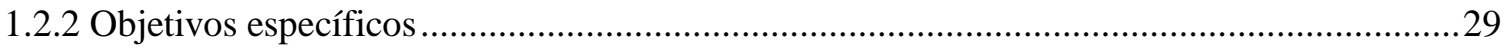

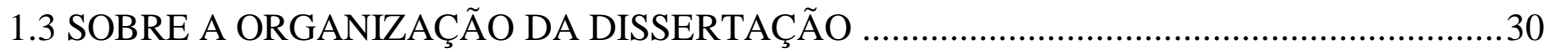

2 A EDUCAÇÃO DE PESSOAS COM SURDOCEGUEIRA …..................................................32

2.1 AS ESCOLAS MUNICIPAIS DE EDUCAÇÃO BILÍNGUE PARA SURDOS (EMEBS) ........38

2.2 PLANOS INDIVIDUALIZADOS: UM CAMINHO PARA A EQUIDADE..............................47

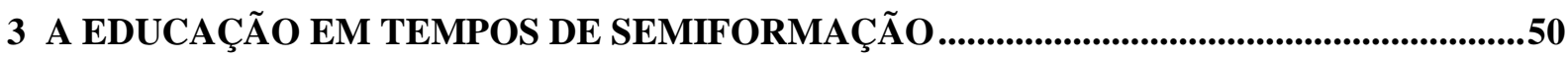

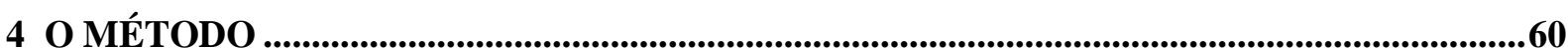

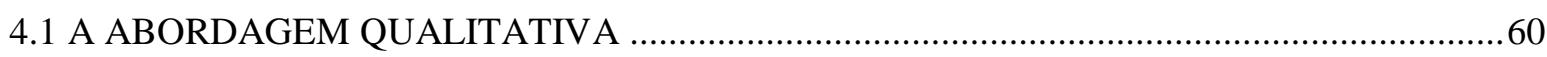

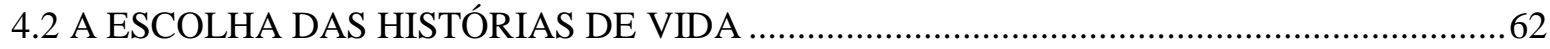

4.3 SOBRE A ORALIDADE EM TRAJETÓRIAS VISUAL-MOTORAS …..................................63

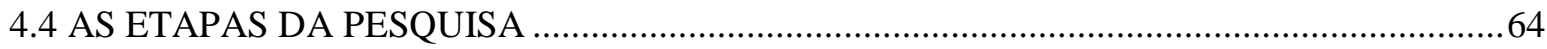

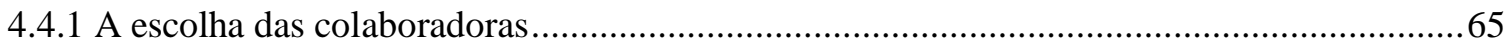

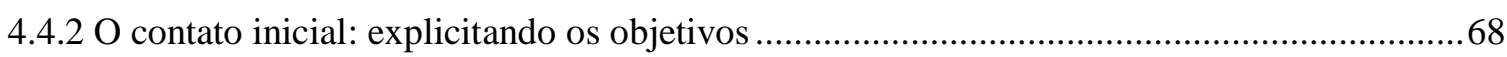

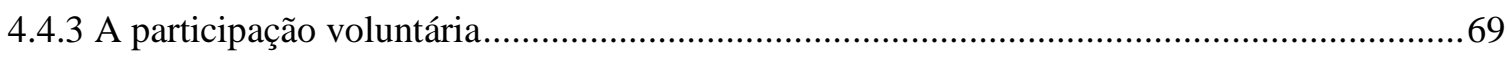

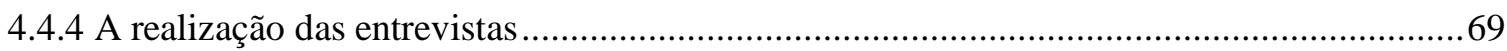

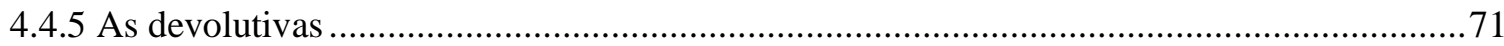

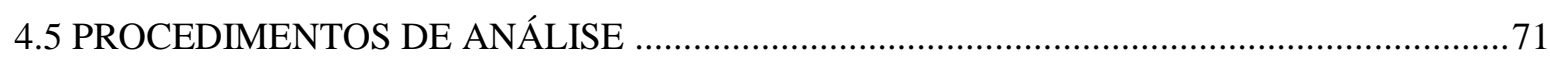

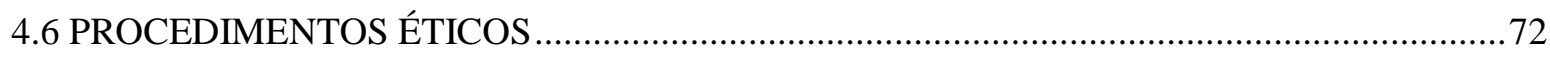

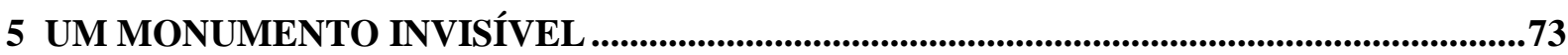

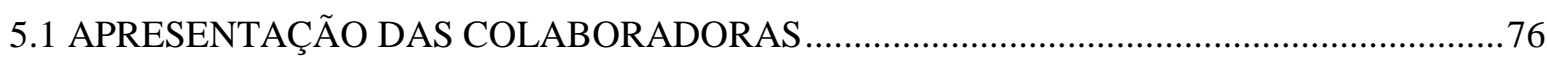

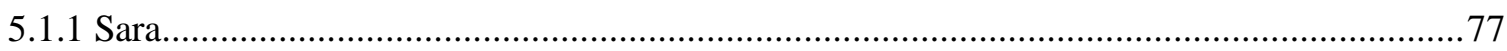

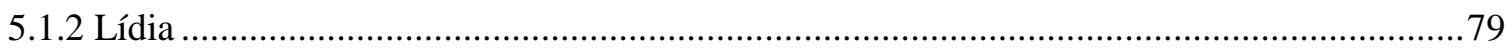

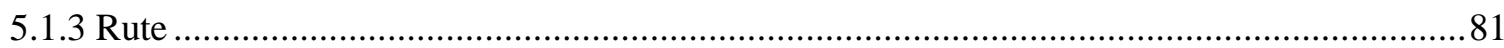

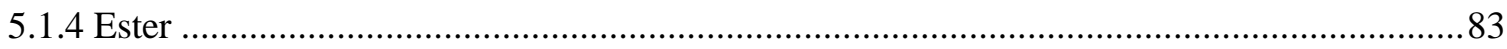




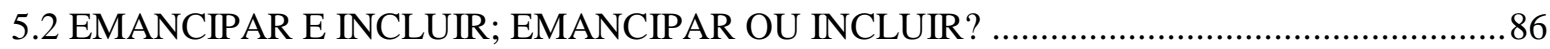

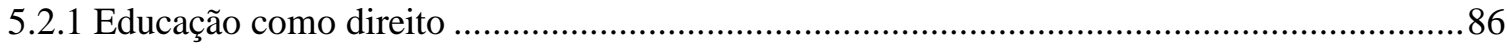

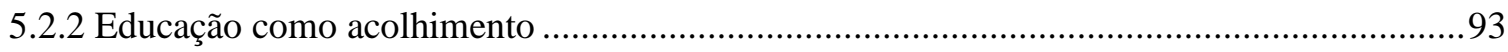

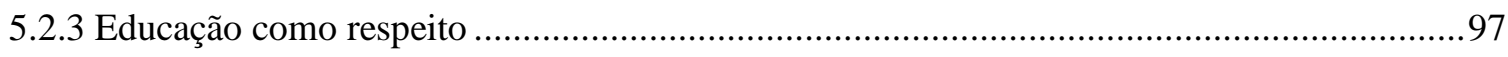

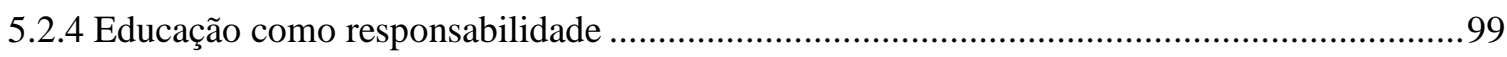

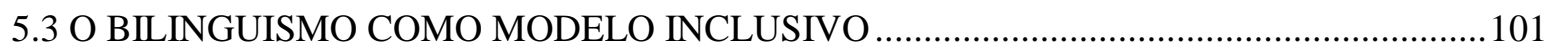

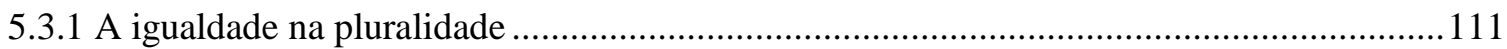

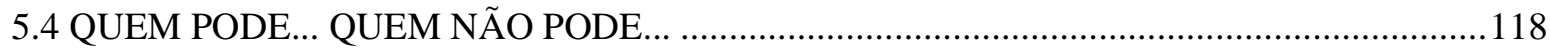

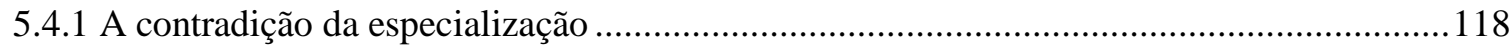

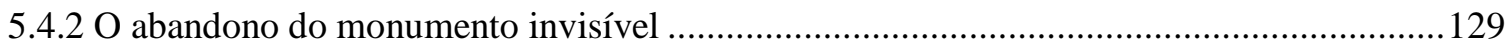

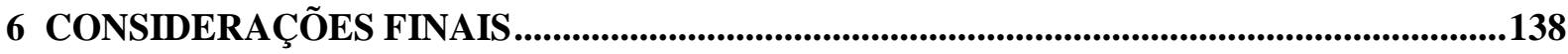

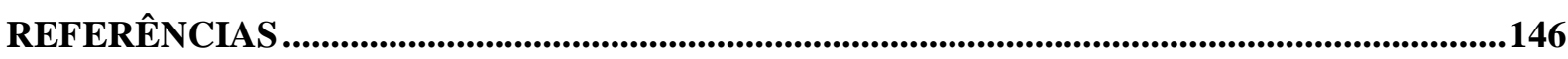

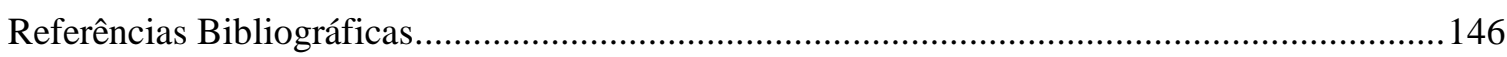

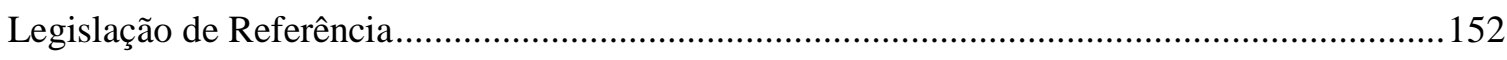

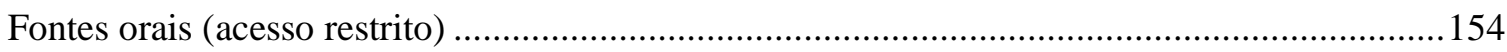

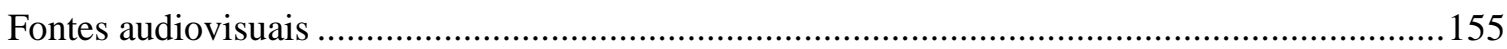

APÊNDICE I - Termo de Consentimento Livre e Esclarecido (TCLE) .....................................156

APÊNDICE II - Termo de Compromisso de Utilização dos Dados (TCUD)...................................159

APÊNDICE III - Quadro-síntese do levantamento realizado no Banco de Teses USP ................160 


\section{APRESENTAÇÃO}

O ingresso na Pós-Graduação do Instituto de Psicologia é o resultado de uma trajetória de mais de vinte anos de experiências práticas e de estudos teóricos em busca de uma compreensão sobre a diversidade humana. Essa questão perpassa minhas investigações desde a graduação em História, quando iniciei, sob orientação do Prof. Dr. Augustin Wernet, estudos sobre os imigrantes japoneses.

Ao estudar a questão da imigração, deparei-me com a potência presente no impulso humano para e pela vida, e em minha trajetória profissional e acadêmica posterior, encontrei pessoas completamente diferentes, que mesmo frente às maiores adversidades, mostravam a manutenção desse impulso pela vida, sem nenhum titubeio. Compreender essa certeza, ou pelo menos pensar sobre ela, é algo que dá sentido a este trabalho.

Sobre o mestrado em História Social, o mesmo foi iniciado logo após o término da graduação, mantendo o tema da imigração. A pesquisa buscou compreender como se deu a conversão dos imigrantes japoneses para o catolicismo, na cidade de São Paulo, antes da II Guerra Mundial $^{1}$. Foi uma experiência profícua e extremamente importante, mas o caráter "restrito" da produção acadêmica - ao menos devido às características da redação, que restringe o número de leitores - provocou uma grande insatisfação, possivelmente devido à minha própria imaturidade. Sentia uma lacuna: faltava-me a prática, algo sobre o que falar, a partir de vivências incorporadas, o saber decor - de sua origem latina de+cor, isto é, a partir do coração.

Iniciei, nesse período, estudos sobre a Comunidade Surda ${ }^{2}$ junto ao Núcleo de Estudos em História Oral (NEHO), o que me impulsionou a procurar cursos de Língua de Sinais Brasileira (Libras) ${ }^{3}$. Deste período, não podemos deixar de registrar nossos agradecimentos ao Prof.

\footnotetext{
${ }^{1}$ YOKOYAMA, Lia Cazumi. A Conversão ao Catolicismo: Os imigrantes japoneses e seus descendentes em São Paulo. Dissertação (Mestrado em História Social) - Faculdade de Filosofia, Letras e Ciências Humanas Universidade de São Paulo, 2002, 2v. Essa pesquisa contou com uma bolsa de dois anos da Fundação de Amparo à Pesquisa do Estado de São Paulo (FAPESP).

${ }^{2}$ Optamos pela grafia de Comunidade Surda e Surdos com inicial maiúscula, fazendo referência à identificação cultural das pessoas com perda auditiva, e em respeito à mesma, conforme discutido por Padden e Humphries (1999).

${ }^{3}$ A Língua de Sinais Brasileira (Libras), segundo o Art. $1^{\circ}$ da Lei $n^{\circ} 10.436$ de 24 de abril de 2002, é a "a forma de comunicação e expressão, em que o sistema lingüístico de natureza visual-motora, com estrutura gramatical própria, constituem um sistema lingüístico de transmissão de idéias e fatos, oriundos de comunidades de pessoas surdas do Brasil."

Na legislação, utiliza-se Língua Brasileira de Sinais (LIBRAS), com a sigla toda em caixa alta. Contudo, seguimos a grafia proposta por Capovilla e Raphael (2005), que segue o padrão mundial e utiliza o termo língua se sinais como uma expressão única em "Li", seguida de adjetivações como americana, francesa, e no caso, brasileira ("bras").
} 
Dr. Leland McCleary, que me apresentou as primeiras referências bibliográficas para as inúmeras leituras que também compõem a presente pesquisa. E vale lembrar, ainda, que esse contato com a Comunidade Surda me reaproximou com uma experiência que tive, como voluntária, na Associação para Deficientes da Áudio Visão (ADEFAV) - atualmente identificado como Centro de Recursos em Deficiência Múltipla, Surdocegueira e Deficiência Visual -, no início da década de 1990. Na ocasião, Helena Burges foi uma pessoa com quem aprendi muito.

Após a apresentação da dissertação de mestrado na Faculdade de Filosofia, Letras e Ciências Humanas (FFLCH) da Universidade de São Paulo (USP), voltei-me para o estudo das pessoas com deficiência ${ }^{4}$ e matriculei-me no curso de especialização em "Formação de Educadores para Pessoas com Deficiências Sensoriais e Múltiplas Deficiências" ${ }^{5 \%}$, na Universidade Presbiteriana Mackenzie. Nessa instituição, tive contato com grandes especialistas nessa temática, tanto do Brasil como do mundo.

Paralelamente, passei a atuar como professora de inglês no Projeto Educação do Instituto Intercultural, em um curso voltado para estudantes da rede pública. Essa experiência me colocou frente a uma nova realidade: adolescentes que, em sua grande maioria, deslocavam-se para a região central da cidade de São Paulo, vindos inclusive de outras cidades, para assistir a aulas de inglês aos sábados. O Instituto, sob a coordenação da Profa. Karla Bley e gestão de Sérgio Melo, teve papel fundamental para a compreensão de novas abordagens educacionais focadas na comunicação e na formação para além da educação acadêmica - escolarização.

Nesse mesmo período, com a especialização no Mackenzie, surgiram novas oportunidades. Como estava cursando o nível III (avançado) de Libras da Federação Nacional de Educação e Integração de Surdos (FENEIS), comecei a atuar como intérprete ${ }^{6}$ em uma instituição privada de ensino regular que atende alunos Surdos, com uma proposta inclusiva, nos níveis fundamental, médio e superior.

O curso de especialização da Universidade Presbiteriana Mackenzie exigia uma carga horária de estágios em instituições especializadas. Foi quando conheci a AHIMSA - Associação Educacional para Múltipla Deficiência. Ao final do estágio, passei a atuar como educadora de

\footnotetext{
${ }^{4}$ Pessoa com deficiência seguindo a orientação da portaria $\mathrm{n}^{\mathbf{o}} 2.344$, de 3 de novembro de 2010 - CONADE.

${ }^{5}$ Multiple Disabilities foi traduzido inicialmente como Múltiplas Deficiências. Atualmente, utiliza-se deficiência múltipla. Soares (s/d), nos lembra que, desde a década de 1950, essa nomenclatura passou por várias mudanças: "Dupla Deficiência Sensorial, Múltipla Privação Sensorial (MPS), Deficiência Audio-Visual (DAV), Surdez-Cegueira e Surdocegueira (Sc).”

${ }^{6}$ Nesse contexto, ainda não havia a Pró-Libras e a regulamentação no que diz respeito à atuação dos intérpretes de Libras era incipiente. Por ter formação na área de educação e a certificação de uma importante instituição da Comunidade Surda, fui admitida para atuar como intérprete educacional no nível superior.
} 
três alunos que eram atendidos individualmente. Nesse novo contexto, ficava evidente a mudança de foco, que antes apenas parecia um incômodo: não se tratava de enxergar as "difículdades", nem do fato de um aluno com deficiência ter alguma incapacidade (de ver, de ouvir ou de caminhar de forma independente). Minha experiência nessa instituição e o curso de especialização fizeram com que eu, educadora, percebesse a necessidade de re-conhecer o mundo, tendo cada aluno como um novo guia, para então, acolhê-los e fazer o caminho de volta para o nosso mundo social da cultura paulistana, brasileira, ocidental, capitalista e industrializada. Foram aprendizados extremamente importantes, convivendo com profissionais que trabalham há décadas atendendo pessoas com deficiência múltipla sensorial e surdocegueira, das quais não poderia deixar de citar Shirley Rodrigues Maia, Lília Giacomini, Regina Maria de Jesus e Francisca Soares Carneiro, que tanto me ensinaram.

Ao redigir o trabalho de conclusão do curso de especialização ${ }^{7}$, ficou evidente a importância do vínculo no atendimento das crianças com surdocegueira ou com deficiência múltipla sensorial e, diretamente relacionado a esse vínculo - porque o possibilita e é por ele possibilitado - a comunicação-interação. Com essas crianças, o papel do educador como aquele que as introduz ao mundo, tomou um sentido diferente. Arendt (2011, p.238) pensa a escola como a instituição "entre o domínio privado do lar e o mundo". No caso dos alunos com surdocegueira, a escola muitas vezes passa a fazer parte do domínio privado porque precisa atuar diretamente com a família, à medida que aprende com as especificidades de cada aluno, uma forma diferente de vivenciar o mundo e de estar nele.

Minha atuação como professora e como intérprete não exigiam dedicação exclusiva. Sendo assim, foi possível mantê-las simultaneamente, o que, ao meu ver, foi muito rico já que eram, de certa forma, complementares por ampliarem minha compreensão sobre diferentes contextos: a educação especial em instituição especializada, a educação especial em uma perspectiva inclusiva dentro de uma instituição privada, e a educação complementar - ensino de um segundo idioma - em um curso livre.

Esse período de intensa atividade profissional prática alimentou minha ânsia por reflexões teóricas, o que coincidiu com a possibilidade de trabalhar na empresa do escritor e sociólogo Jorge Caldeira. Tratava-se da realização de pesquisas como historiadora, realizando a coleta e organização de fontes documentais que fornecessem dados para a redação de livros e, em

\footnotetext{
7 YOKOYAMA, Lia Cazumi. Reflexões sobre a relevância dos vínculos no processo de aprendizagem do múltiplo deficiente: um estudo de caso. Monografia (Trabalho de Conclusão de Curso) - Especialização em Formação de Educadores de Pessoas com Deficiências Sensoriais e Múltiplas Deficiências - Universidade Presbiteriana Mackenzie, São Paulo, 2003, 79f.
} 
um dos projetos, a produção de um site ${ }^{8}$. Nesse momento, foi possível conciliar essa atividade com minha atuação na AHIMSA, com uma carga horária menor. Alguns anos depois, desligueime desta instituição para dedicar-me somente à pesquisa, por cerca de cinco anos.

Em 2009 fui chamada para atuar na Rede Municipal de Ensino (RME) de São Paulo, como professora de história, devido a um concurso realizado anos antes. Ser professora era o sonho que tinha motivado minha opção na graduação. Fui, então, para a escolha de vagas e ingressei no corpo docente da EMEF Luiz Gonzaga do Nascimento Jr. - Gonzaguinha, na região do Sacomã. Como historiadora, as reflexões sobre a educação e sobre a cidade de São Paulo passaram a fazer parte do meu cotidiano frente a muros culturais difíceis de transpor.

Sendo fruto da rede privada de ensino, a rede municipal era um universo novo. Um lugar onde tive que enfrentar a minha evidente restrição reflexiva no que diz respeito à democracia, e uma tendência a responder às necessidades cotidianas com "soluções privadas". Talvez por isso, contraditoriamente, a sala de aula, apesar da enorme realização pessoal, causava desconforto. Ler obras de Arendt e Adorno, entre vários outros autores que discutem a educação e a sociedade de forma geral, reforçava minha ânsia por compreender melhor as questões políticas e morais, que evidenciavam o "erro" das respostas privadas.

Em 2011, fui convidada pelo Centro de Formação e Acompanhamento à Inclusão (CEFAI) da Diretoria Regional de Educação (DRE)-Ipiranga, para atuar como Professora de Apoio e Acompanhamento à Inclusão (PAAI), por ter em meu currículo a especialização em deficiências sensoriais e múltipla, além de meus conhecimentos em Libras. Devido ao desconforto que vinha sentindo, esse convite foi recebido com um misto de surpresa, insegurança e ânimo: não sabia exatamente o papel do CEFAI, mas abria-se uma possibilidade de crescimento. Minha então ignorância sobre políticas públicas fazia com que eu não tivesse clareza da organização da RME como um todo. Dessa forma, foi no CEFAI que pude conhecer e compreender questões relacionadas ao funcionamento da gestão em instituições públicas, por meio do contato direto com profissionais da Diretoria de Orientação Técnico-Pedagógica (DOT-P) e Supervisores Escolares. Receber formações e orientações da equipe de profissionais da Diretoria de Orientação Técnica de Educação Especial (DOT Educação Especial), além da oportunidade de eu mesma oferecer formações para professores da RME, foram de grande importância em termos de apren-

\footnotetext{
${ }^{8}$ As obras em que atuei como pesquisadora, todas de autoria de Jorge Caldeira, foram: O Banqueiro do Sertão. São Paulo: Mameluco, 2006; Votorantim 90 anos: uma história de trabalho e superação. São Paulo: Mameluco, 2007; Brasil: a História contada por quem viu. São Paulo: Mameluco, 2008. E a elaboração do site: <www.obrabonifacio.com.br>.
} 
dizado profissional e, principalmente, para ampliar minha compreensão sobre a Educação Pública e sua relação com a democracia. Seria impossível listar todas as pessoas, mas não poderia deixar de mencionar Andrea Costa Garcia, então Diretora da DOT-P; Ana Luiza Sodero, então Coordenadora do CEFAI; e a equipe de PAAI, Rosangela Nezeiro Jacob, Sueli Massaro, Renata Garcia e Olga Lebrão.

Durante as formações, ou mesmo em visitas que realizava nas unidades educacionais, as questões relacionadas à finalidade da educação voltaram a causar desconforto e angústia, fazendo com que eu solicitasse o retorno à unidade educacional de lotação. Note-se que me refiro a um descontentamento pessoal, mais relacionado ao contexto. Volto-me contra a estrutura capitalista neoliberal, com características específicas na cidade de São Paulo. Há um forte rechaço, por parte de determinados segmentos sociais, a um empreendimento que deveria ser comum: a consolidação de uma sociedade democrática. Um rechaço ativo, que cria condições objetivas de impedimento ao andamento de ações legais a favor de mudanças. Uma dificuldade para parar esses "dentes de engrenagem", que agem de forma tendenciosa, mesmo quando o foco não é fazer o mal ao outro, mas a garantia do próprio bem e do bem dos seus. Uma forma de agir e de pensar alicerçada na crença de uma suposta meritocracia e de uma falsa justiça, da qual eu também venho tentando me libertar. E essa angústia aparece resumida na citação de Gonçalves Filho por Mendes (2014, p.14): “[...] a comunicação com cidadãos das classes populares pede muitos deslocamentos. Estes deslocamentos culminam, por sua vez, em outro ponto de onde nossa visão vai ver o que não via antes".

Após um ano e meio como PAAI, retornei à minha unidade de origem, apesar da forte identificação com as atividades realizadas na Diretoria de Ensino. Foi uma decisão difícil, principalmente tendo em vista o aprendizado inegável que esse ambiente proporciona. Mas era necessário superar o desconforto: a falta de algo que sanasse o conflito entre uma memória de escola, uma ideia sobre o que é a educação, e a nova realidade em que estava inserida.

Ao voltar para a sala de aula como professora substituta, ou como somos chamadas na RME, como "professora módulo", sem turmas definidas, o desconforto se evidenciou mais fortemente. A inabilidade pessoal de lidar com essa condição, culminou com uma decisão: o pedido de exoneração. Faltava-me a serenidade para lidar com tantas questões: Qual o sentido da educação? Qual o meu papel como educadora? Reprodutora e disseminadora de conhecimentos aceitos e considerados necessários? Apresentar o mundo? Mas qual mundo? Esse que eu não via antes e que estava sendo apresentado a mim? Como apresentar o "meu mundo", sem reproduzir a opressão? Como apresentar o mundo para crianças e adolescentes que evidenciavam serem muito mais maduros do que eu? 
A formação acadêmica não havia garantido conhecimentos para que eu pudesse responder a essas questões de forma assertiva. Nesse momento, era necessário parar para pensar sobre a minha própria história, como propõe Arendt (2004, p.160) ao afirmar que "para os seres humanos, pensar no passado significa mover-se na dimensão da profundidade, criando raízes e assim estabilizando-se para não serem varridos pelo que possa ocorrer”.

A partir dessas reflexões iniciais, foi elaborado um projeto sobre o processo de adoecimento e pedidos de exoneração de professores da rede pública municipal ${ }^{9}$. Com as reuniões de orientação, houve uma reestruturação da questão sob um novo olhar, resgatando minhas experiências na Educação Especial e uma constatação seguida de uma nova dúvida: há mudanças ocorrendo nas escolas da rede pública de ensino. Elas nos permitem pensar sobre a educação que queremos em nossas escolas?

Fui desenvolvendo a pesquisa e, em 2016, por conta de algumas mudanças profissionais, tive a oportunidade de integrar a equipe de educadores que atuaram na mediação da $32^{\mathrm{a}}$ Bienal de São Paulo. Foram quatro meses de formação, seguidos de quatro meses de ações educativas. Além do fato da pesquisa e da escrita desta dissertação terem sido concomitantes à essa formação, ela nos proporcionou conversas com vários artistas convidados para a exposição, e também com os curadores. Essa experiência passou a ter influência direta sobre nossas reflexões, permitindo, inclusive, uma melhor compreensão de textos de Arendt, Adorno e Horkheimer. E essa influência poderá ser notada em todo o texto, principalmente no capítulo teórico "Um Monumento Invisível", cujo título foi retirado de uma conversa com Donna Kukama. Alguns outros artistas são citados nominalmente no decorrer do texto, mas podemos afirmar que outros artistas e curadores que participaram da $32^{\mathrm{a}}$ Bienal, assim como os educadores com quem trabalhei, comparecem neste texto.

Todo esse percurso é apresentado porque essas experiências perpassam o presente estudo. Foi esse deslocamento para esse outro ponto, o "ver o que não via antes", que proporcionou esse retorno à academia. E é com esse novo olhar que se propõe a apresentação de reflexões sobre a inclusão de pessoas com surdocegueira a partir de relatos de profissionais especializados da RME de São Paulo.

\footnotetext{
${ }^{9}$ Esse projeto inicial foi reformulado e transformado em um artigo, apresentado no X Colóquio Internacional do LEPSI, realizado com o $5^{\circ}$ Congresso da RUEPSY e com o I Congresso Brasileiro da Rede INFEIES - Crianças Públicas, Adultos Privados (6-8/nov/2014), com o título "A escola pública em uma cidade regida pela lógica do privado: motes para discussões e reflexões".
} 


\section{INTRODUÇÃO}

A educação na cidade de São Paulo, principalmente relacionada à educação de pessoas com deficiência na rede municipal básica de ensino, vem passando por mudanças que foram ampliadas e fortalecidas desde o final do século XX, quando a perspectiva inclusiva começou a ser difundida. Tendo como um marco importante a Constituição da República Federativa do Brasil de 1988, essas mudanças fazem parte de uma transformação mais ampla: o processo de redemocratização do país ${ }^{10}$.

Podemos ilustrar esse cenário com outras ações relacionadas à garantia dos direitos das pessoas com deficiência e que vêm sendo construídas, em grande parte, com a participação ativa das próprias pessoas com deficiência, tendo como base uma política de estado que, como tal, abrange todo o território nacional. É o caso do reconhecimento da Libras como meio legal de comunicação e expressão, conforme a Lei Federal n ${ }^{\circ}$ 10.436, de 24 de abril de 2002, que resultou de ampla mobilização da Comunidade Surda ${ }^{11}$. Ao mesmo tempo, essa conquista não pode ser compreendida de forma isolada e não se restringe aos direitos das pessoas com deficiência, mas sim a um movimento em defesa dos direitos civis, com a universalização do direito ao voto nos países democráticos, e dos direitos humanos em todo o mundo.

Não é preciso lembrar que as pessoas com deficiência são homens ou mulheres, que também carregam em si as questões de gênero, como qualquer outra pessoa. Têm diferentes posicionamentos políticos e crenças religiosas; são de origem social diversa, e por isso, com necessidades econômicas próprias; enfim, a deficiência é apenas uma entre outras características que precisam ser consideradas ${ }^{12}$. Essa riqueza se evidencia quando atentamos para os movimentos de autodefensoria. Estes estão, em grande parte, relacionados com o surgimento, em

\footnotetext{
${ }^{10}$ Mazzotta e Sousa (2000) trazem mais elementos para se pensar essa questão é apenas pontuada aqui.

${ }^{11}$ Conforme apontado na Apresentação, utilizamos Surdos com a inicial maiúscula quando nos referimos a um grupo específico de usuários da língua de sinais e que se identificam como parte da Comunidade Surda. Note-se que a "definição" e quantificação dessa Comunidade é difícil mesmo nos Estados Unidos e Canadá. Não se trata de um dado estatístico objetivo, como a quantificação de pessoas com um laudo que refere perda auditiva. Uma das características para ser considerado parte da Comunidade Surda é a utilização da língua de sinais, o que implica uma série de aspectos culturais. Para mais discussões sobre a questão, ver Padden e Humphries (1999).

12 Um exemplo que evidencia a importância da associação de fatores distintos é o caso da África do Sul, onde a luta pelo fim da segregação racial acabou se entrelaçando com a luta pelos direitos das pessoas com deficiência, com a presença de personagens como Phindi Mavuso e William Rowland (FAGIN, 2011, p.22-28). Pode parecer inicialmente estranha essa aproximação, mas quando Rowland (2001) nos lembra que, a cada morto na luta contra o apartheid, outros três ficavam com alguma sequela ou deficiência, essa associação parece inevitável. No contexto sul-africano durante o período do apartheid, qualquer característica assumia diferentes significados de acordo com a raça; e ser uma pessoa negra com deficiência implicava em assistência nula por parte do governo.
} 
1981, do Disabled People's International (DPI) com o seu slogan "Nothing About Us - Without $U s^{\prime \prime 13}$ (FLOOD, 2005, p.184).

Uma retrospectiva e análise da história da educação das pessoas com deficiência no Brasil foi elaborada por Silveira Bueno (2011), que já apontava para questões relacionadas aos aspectos econômicos associados à deficiência. Seu trabalho será trazido repetidas vezes como referência para as reflexões que serão estabelecidas neste trabalho e, por isso, dispensamos a elaboração de uma apresentação-síntese do mesmo. Outros estudos acadêmicos como os de Bazon (2009) e Castro (2007) também podem ser citados para se pensar a história da educação especial. Da mesma forma, os artigos mais recentes de Mazzotta (2008), e de Mazzotta e D'Antino (2011) não poderiam deixar de ser citados por destacarem aspectos mais atuais da temática.

Em se tratando da educação bilíngue, as obras de Souza (1998) e Brito (1995) foram escolhidas porque, dentre outras pioneiras que discutiram essa temática, trazem pontos que nos interessam mais diretamente. Sendo assim, ao invés de elencar marcos em uma linha do tempo, importa, aqui, um foco sobre as diretrizes do processo de inclusão de pessoas com deficiência na RME de São Paulo e uma reflexão sobre os seus desdobramentos dando ênfase às escolas bilíngues.

As diretrizes que norteiam as ações atuais foram estabelecidas no Decreto Municipal $n^{\circ}$ 45.415, de 18 de outubro de 2004, e o tomamos como um ponto de partida, pois ele permite uma contextualização mais direcionada às questões aqui estudadas. Suas especificações, alterações e complementações podem ser acompanhados nas ações posteriores da Secretaria $\mathrm{Mu}$ nicipal de Educação. ${ }^{14}$ Destas, podemos citar a realização de vários cursos para professores, coordenadores, diretores, agentes escolares e supervisores, sobre as diferentes deficiências, cursos de Libras, de formação para guias-intérpretes ${ }^{15}$ e, em 2014, tivemos a primeira turma de

\footnotetext{
${ }^{13}$ Nada Sobre Nós, Sem Nós, deriva da expressão política em latim Nihil novi nisi commune consensu.

${ }^{14} \mathrm{O}$ Decreto $\mathrm{n}^{\mathrm{o}} 45.415$ foi alterado pelo Decreto n. $^{\circ} 45.652$, de 23 de dezembro de 2004, e foi regulamentado pela Portaria n. ${ }^{\circ}$ 5.718, de 17 de dezembro de 2004. Esta portaria foi modificada pela Portaria n. ${ }^{\circ}$ 5.883, de 27 de dezembro 2004. A elaboração desses decretos e portarias tiveram como referências nacionais o Estatuto da Criança e do Adolescente (ECA - Lei Federal no 8.069 de 1990) e a Lei de Diretrizes e Bases da Educação Nacional (LDBEN - Lei Federal no 9.394 de 1996), assim como a Resolução n. ${ }^{\circ} 02$ de 2001 do Conselho Nacional de Educação e Câmara de Educação Básica. Tais informações constam no Portal da Secretaria Municipal de Educação: <http://portalsme.prefeitura.sp.gov.br>. Acesso em 21 de janeiro de 2014.

Mais recentemente tivemos o Decreto no 51.778, de 14 de setembro de 2010, "Institui a Política de Atendimento de Educação Especial, por meio do Programa Inclui, no âmbito da Secretaria Municipal de Educação e dá outras providências", tendo uma sequência de Portarias complementares como as de $\mathrm{n}^{0} 2.496$, de 02 de abril de 2012, que regulamenta as Salas de Apoio e Acompanhamento à Inclusão, e a de no 2.963 , de 15 de maio de 2013, que organiza o quadro de Auxiliares de Vida Escolar - AVEs e de Estagiários de Pedagogia.

${ }^{15}$ Segundo informações constantes na página do Portal da Secretaria Municipal de Ensino da Prefeitura de São Paulo, só no ano de 2013, "cerca de seis mil educadores estiveram em formação continuada" e essa é a meta mínima anual, conforme informações nessa mesma página. "Política Municipal de Ed. Especial na Perspectiva da Ed. Inclusiva". Disponível em: <http://portalsme.prefeitura.sp.gov.br/AnonimoSistema/MenuTexto.aspx? MenuID=277\&MenuIDAberto=162 >. Acesso em 23 de março de 2015.
} 
Especialização com ênfase em Deficiência Múltipla ${ }^{16}$, após cerca de dez anos de formações de vários grupos de professores em cursos de Especialização em Deficiência Intelectual e, mais recentemente, em Deficiência Auditiva, por meio de convênio estabelecido entre a Secretaria Municipal de Educação (SME) com grandes universidades.

Outras diretrizes estabelecidas no referido decreto encontram-se objetivadas na organização dos recursos humanos e atendimentos, tais como:

1) uma equipe multidisciplinar na Secretaria Municipal de Educação (SME), composta por especialistas em educação especial que atuam na Diretoria de Orientação Técnica (DOT)Educação Especial;

2) a composição de Centros de Formação e Acompanhamento à Inclusão (CEFAI $)^{17}$ nas Treze Diretorias Regionais de Educação (DRE);

3) uma equipe de especialistas em educação especial nessas Diretorias Regionais de Educação (DRE) para atuar nesses CEFAI como Professor de Apoio e Acompanhamento à Inclusão (PAAI);

4) o atendimento educacional especializado (AEE) complementar oferecido no contra turno nas salas de apoio e acompanhamento à inclusão (SAAI);

5) a possibilidade dos alunos com deficiência frequentarem, também no contra turno, instituições conveniadas à Prefeitura de São Paulo, onde são oferecidas atividades de enriquecimento curricular (AEC) e de iniciação ao mundo do trabalho (IMT);

6) a existência de centros de atendimento educacional especializado (CAEE);

\footnotetext{
A mais recente publicação no portal foi o Espaço Virtual de Educação Bilíngue, em comemoração ao Dia Nacional dos Surdos, e que consiste em um "espaço de pesquisa e compartilhamento de materiais que ajuda Professores Bilíngues, Intérpretes de Libras, Guias-Intérpretes, Instrutores de Libras e toda a comunidade escolar a se informar e se formar para atuar em favor da educação bilíngue para surdos". Disponível em: <http://portal.sme.prefeitura.sp.gov.br/Main/Noticia/Visualizar/PortalSMESP/Espaco-Virtual-de-Educacao-Bilingue>. Acesso em $27 \mathrm{de}$ setembro de 2015 .

Com relação aos cursos de Pós-Graduação em nível de Especialização, de 2006 a 2008, foram formados 250 professores da Rede Municipal de Ensino, em parceria com a UNESP-Marília. Ver dados disponíveis em: <http://www.portalsme.prefeitura.sp.gov.br/anonimo/edesp/acoes.aspx>. Acesso em 10 de fevereiro de 2014.

${ }^{16}$ Esta especialização está sendo oferecida pela Prefeitura Municipal de São Paulo aos servidores da rede, em parceria com a Universidade Presbiteriana Mackenzie. Ver comunicado $n^{\circ}$ 659, de 03 de abril de 2014, publicado no Diário Oficial da Cidade de São Paulo no dia 04 de abril de 2014, p.39.

${ }^{17}$ As diretrizes para essa estrutura, com o CEFAI, o cargo de PAAI e as SAAI, já constavam no Decreto Municipal 45.415, de 18 de outubro de 2004. Isto mostra como a questão da inclusão independe do partido político. Há diferenças e alterações, mas ao menos na esfera administrativa, a relevância e necessidade da inclusão de pessoas com deficiência não parecem mais ser questionadas, ficando o foco das discussões nas ações complementares necessárias para a garantia da qualidade do atendimento de todas as crianças e adolescentes.
} 
7) a contratação de auxiliares de vida escolar (AVE) e de estagiários de pedagogia especificamente para aprendizado sob orientação dos CEFAI, entre outras ações envolvendo transporte, saúde, alimentação, acessibilidade arquitetônica e tecnologia assistiva ${ }^{18}$.

Sabe-se que não basta uma legislação formalizando estruturas se elas não funcionarem de forma efetiva e assertiva. Porém, esses suportes e recursos deixam clara uma postura que não vê apenas na figura dos professores a responsabilidade sobre a inclusão. Pelo contrário: evidencia a percepção da complexidade, em termos de suportes e serviços necessários, com a chegada dos alunos com deficiência na rede regular de ensino. Uma percepção para além do compartilhamento físico de um espaço comum, que ampliou a discussão sobre a inclusão. Não se trata de uma ação isolada de um professor, não se trata de responsabilidade exclusiva da escola, mas sim, exige a responsabilização e participação de toda a sociedade.

A inclusão dos alunos com deficiência chamou a atenção para necessidades mais amplas, que transparecem na Portaria Intersecretarial n ${ }^{\circ} 22$ de 10 de dezembro de 2004. Essa Portaria, envolvendo quatro Secretarias - Educação, Assistência Social, Subprefeituras e Saúde institui um grupo de apoio à inclusão no âmbito de cada subprefeitura de São Paulo. Pode parecer algo de pouca importância, mas quando se percebe as possibilidades de ações voltadas à acessibilidade física, essa visão intersecretarial tem suma importância, pois aponta para uma mudança comportamental, uma ação conjunta por uma política pública de acessibilidade.

Seis anos depois, a SME, por meio do Decreto 51.778, de 14 de setembro de 2010, institui o Programa Inclui ${ }^{19}$, que contém sete projetos:

1. Identificar;

2. Apoiar;

3. Formar;

4. Acessibilidade;

5. Rede;

6. Reestruturação das Escolas Municipais de Educação Especial - EMEE;

7. Avaliar.

\footnotetext{
${ }^{18}$ Sobre o conceito Tecnologia Assistiva, conforme Ata da VII Reunião do Comitê de Ajudas Técnicas - CAT, realizadas nos dias 13 e 14 de dezembro de 2007: "Tecnologia Assistiva é uma área do conhecimento, de característica interdisciplinar, que engloba produtos, recursos, metodologias, estratégias, práticas e serviços que objetivam promover a funcionalidade, relacionada à atividade e participação, de pessoas com deficiência, incapacidades ou mobilidade reduzida, visando sua autonomia, independência, qualidade de vida e inclusão social." Disponível em: <www.infoesp.net/CAT_Reuniao_VII.pdf>. Acesso em 05 de junho de 2015.

19 Vale lembrar que desde 2008 temos a Política Nacional de Educação Especial na Perspectiva da Educação Inclusiva, alicerçada em documento elaborado pelo Grupo de Trabalho nomeado pela Portaria Ministerial $\mathrm{n}^{\circ} 555$, de 5 de junho de 2007, prorrogada pela Portaria n ${ }^{\circ}$ 948, de 09 de outubro de 2007. Esse documento, disponível integralmente na internet pelo Ministério da Educação (MEC), reúne os marcos históricos e normativos, sendo importante referência para uma revisão mais ampla.
} 
Destes, o sexto projeto nos interessa diretamente, pois resultou na criação das Escolas Municipais de Educação Bilíngue para Surdos (EMEBS), com a reestruturação das antigas escolas de educação especial - EMEE - para escolas bilíngues. Voltaremos a falar mais detalhadamente sobre as EMEBS um pouco adiante, quando será discutido o decreto $\mathrm{n}^{\circ} 52.785$, de 10 de novembro de 2011.

O que se deve notar é que, atualmente, o Programa Inclui, com essa estrutura, não está mais em vigência, e o sexto projeto, de reestruturação, já foi concretizado. Os demais projetos continuam em andamento, de forma integrada, sem essa identificação segmentada, tendo como norte a execução da Meta 54 do Plano de Metas do Governo (2013-2016): "Revitalizar os Centros de Formação e Acompanhamento à Inclusão - CEFAI assegurando a formação de professores e o acompanhamento aos educandos com deficiência matriculados na Rede Municipal de Ensino". ${ }^{20}$

Há, pois, uma série de ações sendo realizadas. Por outro lado, perdura um discurso que questiona a presença dos alunos com deficiência na rede regular, principalmente quando se trata de escolas particulares. Afirmar que é um discurso preconceituoso seria uma simplificação que levaria à perda de muitos aspectos importantes. A crença na validade e importância da "sala especial" ou da "escola especial" tem, não raras vezes, origem em falas de familiares de pessoas com deficiência, que exigem o atendimento especializado, por ser esse o modelo predominantemente conhecido e considerado protegido.

Andrew Solomon (2013) elenca inúmeros relatos de pais que se posicionam contra ou a favor da inserção de alunos com deficiência na rede regular de ensino. São falas de norte-americanos, mas cabem aqui por trazerem registros diversos que remetem a diferentes formas de lidar com a deficiência. Formas boas? Ruins? Não vem ao caso. Assim como nos Estados Unidos, e em todo o mundo, há diferentes formas de lidar com a questão da deficiência.

Analisando a realidade brasileira, Silveira Bueno (2004, p.99-115), no já referido estudo sobre o histórico da educação especial, faz uma retrospectiva do período imperial ao final da década de 1970. Seu estudo destaca algumas características como a força das instituições filantrópico-assistenciais e das entidades privadas. Hoje, trazendo ações realizadas na esfera municipal, relacionadas à política de estado, vemos um cenário diferente do apresentado por Silveira Bueno - ainda que com traços herdados desse período estudado por ele - e que ainda não consegue fornecer uma resposta às perguntas lançadas em sua pesquisa:

\footnotetext{
${ }^{20}$ Conforme apresentação em <http://portal.sme.prefeitura.sp.gov.br/Main/Page/PortalSMESP/Apresentacao-2〉. Acesso em 15 de junho de 2015.
} 
De que adianta a manutenção, por exemplo, de crianças deficientes em classes especiais se, ao fim de 4, 5 e até mesmo 10 anos, elas não conseguem ultrapassar os níveis iniciais de escolaridade? De que adianta considerar que a "classe X, Y ou Z" atingiu níveis de $3^{\mathrm{a}}$ ou $4^{\mathrm{a}}$ séries, se uma avaliação um pouco mais refinada comprova que essas crianças não conseguiram incorporar um mínimo de conteúdo correspondente a essas mesmas séries?” (Silveira Bueno, 2011, p.125)

A partir dessas questões, esse autor apresenta o seguinte argumento: "Se esses são os resultados de sistemas especiais de ensino, não resta dúvida de que os processos de inclusão acarretarão poucos prejuízos à população deficiente.” (Silveira Bueno, 2011, p.126)

Evidentemente, o autor desenvolve com uma discussão muito mais profunda e valiosa para questionar a segregação. Trazer apenas essa colocação acaba sendo um tanto traiçoeiro, porque deixa aberta uma porta que pode levar a interpretações que eram comuns na primeira metade do século XX, e o trecho citado não deixa claro que essas interpretações "científicas" que circunscrevem o fracasso dos alunos com deficiência no âmbito individual ou que delegam às condições socioeconômicas, as causas de uma suposta anormalidade, foram criticadas pelo próprio autor em seu estudo sobre os marcos históricos (Silveira Bueno, 2011, p.109).

Devemos ressaltar o fato de que as próprias pessoas com deficiência, seja como parte de coletivos que defendem o "Nada Sobre Nós - Sem Nós", seja como indivíduos com experiências de vida próprias, passaram a lutar pelo direito de ocupar espaços públicos e comuns, e de agir publicamente. Ouvir o que eles têm a dizer, aqui, parece ser urgente. Se por um lado há aspectos significativos em termos de conquistas e ampliação da participação política direta, por outro, no que se refere à educação especial, essa perigosa ideia de uma suposta normalidade perdura. O que vemos é a criação de níveis de aproximação a essa normalidade e quando se trata de pessoas com comprometimento físico severo ou de pessoas com surdocegueira, a crença na necessidade de uma "escola especial" perdura.

Não negamos que é possível enxergar as ações voltadas para um alinhamento da educação especial, em nível nacional, com a perspectiva inclusiva. Porém, as “exceções”, apesar dos inúmeros estudos existentes, apesar das publicações tanto científicas quanto direcionadas ao público em geral, a favor da inclusão de pessoas com deficiência na rede regular, continuam e mostram que ainda faz-se necessário reforçar que o direito de participar, de ocupar os mais diversos espaços, é um direito de todos. Não é seletiva e, como dizia Anísio Teixeira, sobre a educação, ela não é um privilégio. Portanto, não é para "aqueles que dá” ou para "os menos graves".

A lógica da valorização de escolas com altos índices de aprovação nas melhores universidades, evidencia a necessidade de uma discussão muito mais ampla, e a urgência de um res- 
gate mesmo do sentido da Educação, não apenas nas escolas públicas, como também nas escolas privadas. Como defende Silveira Bueno (2011), a extensão e qualificação da escola pública deve romper com o discurso democratizante que não luta de forma eficaz pelo acesso universal ao conhecimento por parte das camadas populares. Isto é, tenham ou não tenham alguma deficiência, sejam ou não sejam ricos, a educação deve deixar de ser privilégio para se tornar efetivamente pública, para todas as pessoas, e gratuita.

Essas reflexões sobre a análise do cenário educacional municipal, que pensa a educação especial em uma perspectiva inclusiva, nos levaram a propor o presente estudo que tem como tema a inclusão de alunos com surdocegueira nas EMEBS da Rede Municipal de Ensino de São Paulo.

Esta pesquisa mostrou-se necessária porque, se na última década a inclusão de alunos com deficiência nas escolas municipais da cidade de São Paulo vem sendo fortalecida e vem crescendo quantitativamente, a inclusão de alunos com surdocegueira tem sido pouco referenciada em estudos acadêmicos. Esse dado se evidencia quando se leva em consideração a ampla produção sobre o tema da educação de forma geral.

Dois estudos nos trazem dados específicos para a definição de nossa pesquisa: Maia (2011, p.113) traz a fala de pais e pessoas não especializadas que atendem crianças com surdocegueira em outros municípios, que não São Paulo, com informações importantes referentes a esses contextos e indica caminhos para pensarmos sobre os profissionais não especializados que atuam no cenário inclusivo da cidade de São Paulo. Já o trabalho de Cormedi (2011, p.132) traz entrevistas com profissionais que atuaram ou atuam com alunos com surdocegueira ou com deficiência múltipla em instituições especializadas, em programas de inclusão em escolas regulares e que tivessem experiência em educação especial, sem citar em qual cidade ou o estado.

Partindo desses estudos para a definição de nosso tema, vimos a necessidade de pesquisar o cenário de produção acadêmica de forma mais ampla. Um levantamento inicial no Banco de Teses USP ${ }^{21}$, com uma leitura rápida de estudos sobre a educação especial, fez com que encontrássemos dois trabalhos que apresentam quantificações relacionadas a alunos com surdocegueira. Martins (2010, p.106) faz referência ao atendimento de alunos com surdocegueira em Escolas Municipais de Educação Especial (EMEE) e na Tabela 2 (Martins, 2010, p.111), traz uma somatória de vinte e dois alunos com surdocegueira atendidos na rede municipal de

\footnotetext{
${ }^{21}$ Quadro-síntese anexo (Apêndice III - Quadro-síntese do levantamento realizado no Banco de Teses USP). As buscas foram realizadas com o uso dos termos surdo-cego, surdocego, surdocegueira e deficiência múltipla sensorial).
} 
São Paulo. Essa informação diverge de Gonzalez (2013, p.134-135), que informa que haviam apenas dois alunos com surdocegueira nessa mesma rede, no ano de 2011.

Tendo em vista essa discrepância nos dados, foi solicitada à SME a quantificação atual de alunos com surdocegueira matriculados na rede. Segundo documento recebido em 2015, havia, então, vinte e três alunos com surdocegueira matriculados. Destes, dez estão em EMEBS, cinco em Unidades-Polo da RME, dois frequentam a rede regular na modalidade de Educação de Jovens e Adultos (EJA), dois em instituições conveniadas à RME, três frequentam o ensino fundamental na rede regular e um, o ensino médio, na rede regular.

Continuamos a análise quantitativa do cenário de produção acadêmica ${ }^{22}$ - pois procedemos apenas à leitura dos resumos, da introdução e das considerações finais - e foram identificados, ainda, dezenove trabalhos especificamente sobre a surdocegueira, e um sobre a deficiência múltipla sensorial. Deparamo-nos, ainda, com a publicação organizada por Masini (2011), que não apenas lista, mas também discute e apresenta grande parte dos estudos localizados. Essa descoberta foi extremamente relevante por confirmar o que havíamos notado: as pesquisas sobre surdocegueira e deficiência múltipla no Brasil são recentes. A mais antiga é uma dissertação de mestrado apresentada em 1999. Já a primeira tese de doutorado sobre pessoas com surdocegueira que foi defendida no Brasil, data de 2003, na Universidade de São Paulo.

Outro dado que pudemos confirmar com a leitura de Masini (2011, p.17) diz respeito a algo que havíamos percebido a partir da leitura dos resumos: predominam nessa produção, estudos de caso, e as entrevistas são a forma mais utilizada para coleta de dados. Além disso, o tema "comunicação" perpassa todos os estudos e o mais significativo, o perfil da maioria dos pesquisadores: profissionais especializados que atuam ou atuavam com o atendimento educacional e/ou terapêutico a pessoas com surdocegueira antes de ingressarem nos cursos de pósgraduação stricto sensu e realizarem essas pesquisas acadêmicas.

\subsection{PROBLEMATIZAÇÃO}

As questões que nortearam o estudo foram: como se dá a chegada de alunos com surdocegueira nessas unidades? O que a chegada desses alunos causa nesses professores especialistas? Como compreender a educação especial em uma perspectiva inclusiva, frente a uma escola

\footnotetext{
${ }^{22}$ Banco de Teses e Dissertações Mackenzie; Biblioteca Digital Brasileira de Teses e Dissertações; Biblioteca Digital da UNICAMP; BIREME - Biblioteca Virtual em Saúde; Banco de Teses CAPES; SCIELO.
} 
bilíngue para Surdos? Qual o papel dos profissionais envolvidos nesse processo? Qual a relevância de um espaço especializado ${ }^{23}$ ?

Para reunir informações sobre a educação de alunos com surdocegueira e sobre essas EMEBS, a presente pesquisa se propôs a ouvir relatos de profissionais que atuam ou atuaram nessas unidades, que sabem Libras, que atuaram direta ou indiretamente na inclusão de alunos com surdocegueira e que apresentaram interesse em contribuir, voluntariamente, com o presente estudo.

Há cento e oitenta e quatro educadores, entre equipe gestora, equipe docente e agentes de apoio, inspetores e auxiliares técnicos, atuando nas seis EMEBS de São Paulo ${ }^{24}$. Por muitos anos, alguns professores, principalmente o que atuavam no Ensino Fundamental II nessas escolas, eram pedagogos que assumiam as aulas, nas mais diversas disciplinas, como matemática, português, geografia, história, entre outros, para suprir a falta de professores licenciados com a referida especialização. Atualmente, o cenário é outro. Portanto, nos pareceu importante buscar uma professora do Ensino Fundamental I e uma professora do Ensino Fundamental II, para ouvirmos esses profissionais mais novos, que também tiveram contato com alunos com surdocegueira.

Por que ouvir esses profissionais, incluindo esses professores? Para não nos atermos a uma ideia, a um pré-conceito de profissional da educação da Rede Municipal de Ensino de São Paulo no início do século XXI. Para ouvirmos a canção olhando para o cantor, atentando para o palco onde ele se encontra, sem deixar de lado o seu contexto individual, conforme pensado por Goodson (2000, p.67), em referência às reflexões de Robin Morton, estudioso da canção popular.

Por que profissionais e não pais ou outros alunos? Porque acreditamos na importância do papel dos educadores no que diz respeito à transformação social, e porque é na fala desses profissionais que encontramos pistas para compreender como essas transformações, que ocorreram no nível das políticas públicas da Rede Municipal de Ensino, foram recebidas no cotidiano escolar e, ainda, como ações e mobilizações dessas comunidades interferiram na elaboração das políticas públicas.

\footnotetext{
${ }^{23}$ A escolha dessas unidades para lotação e exercício, exige a Especialização em Deficiência da Áudio Comunicação (EDAC) ou, atualmente, outras especializações na área da Educação Especial, com ênfase em surdez e profissionais com Especialização em Deficiência Múltipla Sensorial e Surdocegueira. Vale uma consulta à portaria $\mathrm{n}^{\mathrm{o}} 3.560$, de 27 de junho de 2014, que "Estabelece procedimentos para designação para a função de professor regente de classe/aulas nas Escolas Municipais de Educação Bilíngue para Surdos - EMEBS e Unidades Polo da Rede Municipal de Ensino nos casos que especifica."

${ }^{24}$ Quantificação retirada de dados disponíveis no portal da Prefeitura de São Paulo: <http://portalsme.prefeitura.sp.gov.br/AnonimoSistema/BuscaEscola_google.aspx>. Acesso em 16 de julho de 2015.
} 
Interessava-nos reunir, também, dados sobre diferentes percepções frente às transformações metodológicas e à coexistência, ou não, de diferentes abordagens no ensino de pessoas com deficiência auditiva, do oralismo ao bilinguismo. Os estudos conceituais geralmente simplificam aspectos extremamente complexos sobre uma única linha do tempo, como se tudo ocorresse de forma sequencial e com conflitos bipolarizados - e entendemos que isso ocorre como excelente estratégia didática e explicativa. Porém, a multiplicidade que pode se notar nas discussões entre Surdos - que se identificam como parte de uma comunidade específica - e pessoas com deficiência auditiva, fez com que nos deparássemos com uma complexa e dinâmica rede de relações. O cotidiano real dessas pessoas, para além das teorias sobre eles, é um misto de todas as abordagens de ensino e metodologias.

\subsection{CAPITULANDO OS OBJETIVOS}

Partindo dessas considerações, importa capitular os objetivos - geral e específicos - do presente estudo.

\subsubsection{Objetivo Geral}

- Propiciar uma reflexão sobre as mudanças na educação a partir do olhar de profissionais especializados da Rede Municipal de Ensino de São Paulo frente à inclusão de alunos com surdocegueira.

\subsubsection{Objetivos específicos}

- Pontuar elementos das narrativas sobre as histórias de vida das colaboradoras que participaram da pesquisa e sobre a sua atuação profissional, principalmente na EMEBS.

- Problematizar as escolhas e ações durante o exercício de sua profissão, visando compreender seu olhar sobre o objetivo da educação.

- Analisar os relatos dos profissionais das EMEBS sobre as mudanças metodológicas, buscando reunir informações sobre esse processo. 


\subsection{SOBRE A ORGANIZAÇÃO DA DISSERTAÇÃO}

A presente dissertação foi organizada em quatro capítulos. O primeiro, intitulado A Educação de Pessoas com Surdocegueira, procura apresentar um breve histórico sobre a educação de pessoas com surdocegueira na cidade de São Paulo. Resgatam-se experiências próximas, em outras cidades, que influenciaram as instituições paulistanas. Breves discussões teóricas sobre metodologias de ensino de pessoas com surdocegueira também serão trazidas para iluminar as discussões. Em seguida, apresentamos o cenário: As Escolas Municipais de Educação Bilíngue para Surdos (EMEBS), assim como as discussões sobre a educação de Surdos, no que diz respeito às metodologias e abordagens educacionais, pois estas convergem, em vários aspectos, com a educação dos alunos com surdocegueira. No final do capítulo, apresentamos uma breve discussão sobre os Planos Individualizados como um caminho para a equidade e uma ação que já vem sendo implantada tanto em escolas da rede municipal, como em escolas da rede estadual e em escolas privadas.

O segundo capítulo introduz reflexões relacionadas à Educação em Tempos de Semiformação, e enuncia a discussão que se pretende desenvolver paralelamente à pesquisa empírica: a produção de uma consciência verdadeira contra qualquer forma de violência, a formação de sujeitos autônomos e a ideia de crise como oportunidade. Para tanto, as referências teóricas utilizadas podem ser localizadas nas obras de Adorno: Educação e Emancipação e Teoria da Semicultura; de Adorno e Horkheimer: Dialética do Esclarecimento; e de Arendt: Entre o Passado e o Futuro, A Condição Humana e Responsabilidade e Julgamento.

O terceiro capítulo traz uma apresentação detalhada do Método: desde a opção pela abordagem qualitativa e pelas histórias orais de vida, até os procedimentos de análise e éticos. As principais referências bibliográficas para essas discussões foram as obras sobre e pesquisas em história oral de Meihy (2000; 2015), Meihy e Ribeiro (2011) e Ribeiro (2007); e as reflexões éticas levantadas por Schmidt (2008) e Portelli (1997).

O quarto e último capítulo, intitulado Um Monumento Invisível, foi dividido em quatro partes. Na primeira, apresentamos as quatro colaboradoras que foram entrevistadas para esta pesquisa. A partir dessa apresentação, estabelecemos três eixos principais para a discussão teórica com excertos retirados das entrevistas: Emancipar e incluir; emancipar ou incluir?, que buscou compreender como essas educadoras entendem a educação e a inclusão; $\underline{O}$ bilinguismo como modelo inclusivo, que se une à luta dos Surdos para a garantia de uma educação bilíngue, procurando mostrar como esse modelo é efetivamente inclusivo ao assegurar a igualdade na pluralidade; e por fim, Quem pode... quem não pode..., onde refletimos sobre a categoria de 
normalidade, trazendo a especialização dos professores como um norte para se pensar a educação de Surdos fora da educação especial, mantendo a perspectiva inclusiva com um foco cultural. 


\title{
2 A EDUCAÇÃO DE PESSOAS COM SURDOCEGUEIRA
}

\begin{abstract}
Uma das [desvantagens] que mais senti, e ainda sinto, é a falta de tempo. Eu e minha mente costumávamos ter tempo para pensar, refletir. Sentávamos juntas ao anoitecer e ouvíamos as melodias interiores do espírito, que se ouve apenas em momentos de lazer, quando as palavras de algum poeta amado tocam uma corda profunda e doce na alma até então silenciosa. Na faculdade, porém, não há tempo para comungar com os próprios pensamentos. Parece que se vai para a faculdade para aprender, não para pensar. Ao se entrar pelos portais do aprendizado, deixam-se os mais caros prazeres - solidão, livros e imaginação - do lado de fora com pinheiros sussurrantes. Acho que devo encontrar algum conforto na ideia de que estou amealhando tesouros para usufruto futuro, mas estou imprevidente o bastante para preferir a alegria atual a estocar as riquezas para um dia de chuva.
\end{abstract}

(Keller, 2008, p.93)

As palavras de Helen Keller, descrevendo angústias decorrentes de reflexões sobre sua vida na faculdade, na década de 1900, denunciam questões que dialogam diretamente com o presente estudo. Estamos falando em educação, de forma ampla e, em educação para pessoas com surdocegueira, de forma específica. Na realidade, a distinção é apenas necessária enquanto o princípio da educação democrática não demonstra maturação suficiente, exatamente por ter sido objetivado, em forma de lei, recentemente - a Constituição de 1988 ainda não completou nem trinta anos - e por isso deve abarcar ações políticas, culturais, sociais e pedagógicas, para que possa efetivamente ser consolidada.

Falamos em falta de maturidade e caracterizamos as discussões democráticas como sendo recentes, tendo em vista a Constituição de 1988. No entanto, deve-se compreender a importância de ações que a antecederam e que criaram as condições para sua consolidação e existência. O processo de redemocratização em si não ocorreu instantaneamente, em uma data. Pelo contrário, resultou de discussões e lutas de diferentes setores da sociedade, mais notadamente nas décadas que 1970, 1960, 1950 e já transparecia em diferentes situações na primeira metade do século XX e nos séculos anteriores. Esse aspecto aparece de forma significativa em Silveira Bueno (2004, p.125), que resgata aspectos históricos trazendo como exemplo as ações políticas legais e, portanto, documentadas, do Centro Nacional de Educação Especial (Cenesp). Essas ações constatam como, na década de 1970, a educação especial é pensada como priori- 
dade na política educacional nacional. É nessa década que a educação especial passa a ser organizada de forma integrada e planificada (Silveira Bueno, 2004, p.126) ${ }^{25}$. Uma educação especial que propunha uma educação segregada e recorria a instituições filantrópicas e privadas - atualmente criticada por muitos defensores da inclusão. Porém, se não tivesse existido dessa forma, talvez não teria sido possível encontrar o caminho que possibilitou a formulação de reflexões e estudos que hoje nos fazem pensar sobre a importância da perspectiva inclusiva.

A defesa de princípios democráticos pode ser constatada, agora no universo da política educacional, no documento "Política Nacional de Educação Especial na Perspectiva da Educação Inclusiva", que está fundamentada, como consta em sua introdução, na concepção de direitos humanos e "avança em relação à ideia de equidade formal ao contextualizar as circunstâncias históricas da produção da exclusão dentro e fora da escola” (Brasil, 2008).

É interessante resgatarmos o exemplo de Helen Keller, pois o risco da produção da exclusão a partir de seu exemplo se faz muito presente. Devemos reconhecer seu mérito no que diz respeito ao seu domínio de diferentes idiomas, de diferentes formas de comunicação e até mesmo da oralização ${ }^{26}$. Mas será necessário tê-la como referência para o aprofundamento das reflexões nas discussões sobre a produção da exclusão quando o modelo "que se deve atingir" acaba ficando preso a padrões machistas, heteronormativos, brancos, oralistas e "de sucesso".

O risco a que nos referimos está no fato de se utilizar o sucesso de uma única pessoa como base para a definição de um destino ideal comum, para justificar o julgamento daqueles que optam por percursos diferentes. Isto é, quando mantemos um único padrão, no caso, o oralismo, como o parâmetro para o "sucesso", criticando e imputando a responsabilidade de um eventual "fracasso" a uma suposta "falta de esforço" daqueles que não conseguiram - ou não quiseram - ser oralizados. Portanto, a importância histórica de Helen Keller e sua inteligência

\footnotetext{
${ }^{25}$ Uma das ações importantes do Cenesp, conforme Silveira Bueno (2004, p.132) foi o levantamento e organização de dados estatísticos que permitiram uma visualização da situação da educação especial, focada, inicialmente, no atendimento ao excepcional. Em seu histórico, é importante notar as mudanças na forma como eram nomeados os sujeitos, que retrata uma preocupação com as palavras que será o tema de parte de nossas discussões teóricas no capítulo "A educação em tempos de semiformação". De "atendimento a educandos com problemas de aprendizagem", "excepcionais", "deficiente mental", "deficiente intelectual", "pessoa com necessidade especial", "deficiente" ou "pessoa com deficiência", tanto na legislação como em formações, há divergências e discussões. Por exemplo, para refletir sobre a excepcionalidade, Silveira Bueno (2004, p.55-69) dedica um capítulo onde discute A Relação entre Normalidade-Excepcionalidade que introduz suas reflexões sobre a institucionalização.

${ }^{26}$ Em sua biografia, Keller (2008) faz várias menções a seu contato com Alexander Graham Bell. Logo em sua infância, sua família foi ao encontro dele, procurando respostas sobre possibilidades de encontrar uma educação para Helen Keller. Foi ele quem aconselhou o pai de Helen Keller a escrever para o diretor da Perkins School for the Blind solicitando uma professora para Helen. Desde então, sua proximidade com Graham Bell é registrada em diferentes passagens de sua biografia e, inclusive, na dedicatória de seu livro: "A Alexander Graham Bell que ensinou os surdos a falar e capacitou quem ouve a escutar as palavras do Atlântico às Rochosas, dedico esta história da minha vida".
} 
são inquestionáveis, exatamente por ser um caso de "sucesso" dentro dos padrões então impostos. Keller passou a ser cada vez mais ouvida e admirada por conseguir apropriar-se dos códigos dominantes. Contudo, sem deixar de valorizar suas qualidades, é necessário compreender as mudanças sociais e os avanços no sentido da equidade formal, algo pelo que ela própria lutava - não utilizando essa palavra, mas ao que nos parece, com esse mesmo conceito.

Vale destacarmos, ainda, que na citação apresentada no início desta parte, ao notar a falta de tempo para a fruição, para a escolha e para o pensamento, Keller posiciona-se de forma poeticamente indagadora frente a esse código e ritmo que incorpora para sobreviver e se destacar. Mesmo cedendo a ele, a consciência fica evidente, e não espanta quando vemos que é essa personagem que desperta o Brasil - e não seria errado dizer, o mundo - para a educação das pessoas com surdocegueira.

Como começa essa influência? Em 1953, Keller visita o Brasil. ${ }^{27}$ Nessa ocasião, Nice Tonhozi Saraiva, professora de pessoas cegas que conheceu Helen Keller, recebeu o convite para especializar-se na área de surdocegueira na Perkins School for the Blind, nos Estados Unidos. Ao retornar para o Brasil, Nice fundou o Setor de Educação de Deficientes Audiovisuais (SEDAV), que por dois anos funcionou no Instituto Padre Chico, para então passar a funcionar, por pouco tempo, na Fundação para o Livro do Cego no Brasil. A busca por uma estruturação e pela ampliação das ações mais específicas fez com que esses primeiros atendimentos, apoiadas em outras instituições, munisse essa profissional com conhecimentos para dar o passo seguinte. Em 1968, surge a primeira escola para pessoas com surdocegueira no Brasil: a Escola Residencial para Deficientes Auditivos e Visuais (ERDAV), por uma lei municipal (Santos, 2014, p.31). Mas não se tratava de uma escola pública, apesar de contar com apoio governamental. À professora Nice, juntou-se Neusa Basseto, e mais tarde outras profissionais. Foram cerca de dez anos de ações para, em 1977, com o apoio do Professor Geraldo Sandoval, ser realizado o I Seminário Internacional sobre Surdocegueira, que chamou a atenção das autoridades para a educação das crianças com surdocegueira, a partir de modelos internacionais. En-

\footnotetext{
${ }^{27}$ Há registros de pessoas com surdocegueira em instituições de ensino para cegos ou para Surdos, em outros países, desde o século XIX. Julia Brice, em 1835, no asilo de surdos e mudos de Hartford - Estados Unidos; Laura Bridgeman, em 1830, na Perkins School for the Blind - Estados Unidos; Germaine Cambon, em 1860, na escola para meninas surdas em Larnay - França; Helen Keller, em 1887, com sua professora Anne Sullivan, também da Perkins School for the Blind (AMARAL, 2002, p.121). Esta última teve papel importante, pois viajou por todo o mundo e, por ter sido a primeira pessoa com surdocegueira com formação universitária, ao se apresentar publicamente e inclusive falar - pois aprendeu a oralizar - difundiu as possibilidades de desenvolvimento das pessoas com surdocegueira quando recebiam o suporte adequado.

Santos (2014, p.29) cita Victoria Mourriseau na França, no final do século XVII e lista nomes de adultos ativos na luta pela causa das pessoas com surdocegueira: "Maria Francisca da Silva, Claudia Sofia Indalécio Pereira Rodrigues, Carlos Jorge Rodrigues, Alex Garcia, entre outros" (FREDERICO, 2006 apud SANTOS, 2014, p.30).
} 
tretanto, foi em um município vizinho, em São Caetano do Sul, que a primeira instituição pública voltada para pessoas com surdocegueira foi criada: a Fundação Municipal "Anne Sullivan”, que continua atuando na área da educação (Maia, 2002, p.233-234).

Com o passar dos anos, houve o surgimento de novas instituições. Em 1983, foi fundada a Associação para Deficientes da Áudio Visão (ADefAV), e em 1991, foi criada a AHIMSA Associação Educacional para Múltipla Deficiência ${ }^{28}$. As duas instituições foram formadas por educadoras que tiveram influência direta das professoras Nice e Neusa, e continuam atuando no atendimento a crianças com deficiência múltipla sensorial e com surdocegueira. Suas sedes atuais estão localizadas no Ipiranga e na Vila Mariana, respectivamente, e são mencionadas neste trabalho porque mantêm convênio com a Secretaria Municipal de Educação de São Paulo, onde desempenham um papel importante tanto no atendimento complementar - o AEE - como na formação de educadores dessa rede, que recebem alunos com deficiência múltipla, deficiência múltipla sensorial e surdocegueira.

Importa abrir um parêntese para compreendermos o que é a deficiência múltipla, a deficiência múltipla sensorial e a surdocegueira. A legislação, como por exemplo o Decreto Federal n $\mathrm{n}^{\circ}$ 5.296, de 2004, que "regulamenta as Leis nos 10.048, de 8 de novembro de 2000, que dá prioridade de atendimento às pessoas que especifica, e 10.098, de 19 de dezembro de 2000, que estabelece normas gerais e critérios básicos para a promoção da acessibilidade" das pessoas com deficiência ou com mobilidade reduzida, refere apenas as deficiências física, auditiva, visual, mental e múltipla, sem maiores especificações sobre esta última. Já o material produzido pelo Ministério da Educação, distingue Deficiência Múltipla de Surdocegueira e Múltipla Deficiência Sensorial - que atualmente vem sendo utilizado com mais frequência como Deficiência Múltipla Sensorial -, em dois volumes distintos, na sua coletânea intitulada Saberes e Práticas da Inclusão.

Segundo o volume organizado por Francisca Roseneide Furtado do Monte e Idê Borges dos Santos (Brasil, 2006a, p.11):

O termo deficiência múltipla tem sido utilizado, com frequência, para caracterizar o conjunto de duas ou mais deficiências associadas, de ordem física, sensorial, mental, emocional ou de comportamento social. No entanto, não é o somatório dessas alterações que caracterizam a múltipla deficiência, mas sim o nível de desenvolvimento, as

\footnotetext{
${ }^{28}$ Há, também, o CENTRAU em Curitiba, no Paraná. Como focamos a cidade de São Paulo, restringir-nos-emos às instituições desta cidade voltadas ao atendimento educacional de pessoas com surdocegueira. Vale ressaltar que além da parceria com a Perkins, há uma rede de organizações internacionais que participam ativamente de ações diversas, como Seminários e Fóruns internacionais. São elas a Organização Nacional de Cegos da Espanha (ONCE); a União Latino Americana de Cegos (ULAC) do Uruguai, a SENSE International e a The National Deafblind and Rubella Association, da Inglaterra.
} 
possibilidades funcionais, de comunicação, interação social e de aprendizagem que determinam as necessidades educacionais dessas pessoas.

Um pouco adiante, nessa mesma página, há um esclarecimento sobre o conceito de necessidade educacional especial, que "vem romper com essa visão reducionista de educação especial centrada no déficit, na limitação, na impossibilidade do sujeito de interagir, agir e aprender com os demais alunos em ambientes o menos restritivos possíveis."

Já o volume sobre Múltipla Deficiência Sensorial e Surdocegueira (Brasil, 2006a, p.11), traz a seguinte definição para Múltipla Deficiência Sensorial, partindo de Perreault:

Considera-se uma criança com múltipla deficiência sensorial aquela que apresenta deficiência visual e auditiva associadas a outras condições de comportamento e comprometimentos, sejam eles na área física, intelectual ou emocional, e dificuldades de aprendizagem. Quase sempre, os canais de visão e audição não são os únicos afetados, mas também outros sistemas, como os sistemas tátil (toque), vestibular (equilíbrio), proprioceptivo (posição corporal), olfativo (aromas e odores) ou gustativo (sabor).

E sobre a surdocegueira (Brasil, 2006a, p.11-12), resgatando a definição de McInnes e Treffy:

A criança surdocega não é uma criança surda que não pode ver e nem um cego que não pode ouvir. Não se trata de simples somatória de surdez e cegueira, nem é só um problema de comunicação e percepção, ainda que englobe todos esses fatores e alguns mais.

Essa discussão é importante para que a especificidade da privação sensorial seja compreendida como um fator que define práticas pedagógicas e sociais específicas. Portanto, vale pontuar rapidamente algumas discussões sobre as referências teóricas utilizadas na educação de pessoas com surdocegueira e deficiência múltipla sensorial.

Podemos listar algumas abordagens teóricas listadas por Amaral ${ }^{29}$ (2002, p.125-127) como principais influências na educação de crianças com surdocegueira, principalmente até conquistarem o domínio de alguma forma de comunicação autônoma: de Piaget, da modificação comportamental, funcional e de van Dijk. Atente-se para o fato das referências teóricas e metodológicas de ensino utilizadas nas instituições conveniadas ${ }^{30}$ serem necessárias para nossas

\footnotetext{
${ }^{29}$ Isabel Amaral é Consultora do Instituto Hilton Perkins para a América Latina e compunha o corpo docente da especialização em Deficiência Múltipla da Universidade Presbiteriana Mackenzie. Continua tendo influência direta nos países da América Latina, em sua função de Consultora, além de realizar palestras e participar de eventos internacionais.

${ }^{30}$ Parte da equipe da AHIMSA fez uma primeira visita à Perkins School em 1989, quando iniciaram uma parceria com essa instituição (Maia, 2002, p.238). A ADefAV refere o início de uma parceria com o Programa Hilton/Perkins para a América Latina em 1991 (Silva, 2002, p.227). Trata-se da mesma instituição onde Nice Tonhozi Saraiva recebeu treinamento cerca de 20 anos antes.
} 
discussões teóricas, no que diz respeito à educação das pessoas com surdocegueira, principalmente sobre os conceitos. Portanto, apesar de nosso estudo não focar as metodologias de ensino, devemos compreender os seus alicerces, que apareceram nas entrevistas.

Amaral (2002, p.126) concentra a teoria de van Dijk em três bases: o movimento, a comunicação e o desenvolvimento e estrutura do tempo. Ela busca os cinco níveis de desenvolvimento desse autor: ressonância, movimentos coativos, referência não representativa, imitação diferida e gestos/sinais ${ }^{31}$. Em cada um dos níveis, as três bases - movimento, comunicação e desenvolvimento e estrutura do tempo - devem ser desenvolvidas para que a criança possa “adquirir consciência própria separada do ambiente", interagindo com pessoas e objetos de forma significativa (Amaral, 2002, p.127). Isto é, o desenvolvimento tem por objetivo a interação significativa e a autonomia; e autonomia implica em escolhas e pensamento.

Já MacFarland (1993), há mais de uma década, resumiu a teoria de van Dijk, de forma mais detalhada, visando sua implementação por professores. MacFarland (1993, p.24-26) lembra que há dez componentes norteadores quando se pensa em uma pessoa com surdocegueira: a privação sensorial, a integração da informação sensorial, a formação de conceitos, o vínculo, o distanciamento progressivo, a estruturação (do próprio mundo), a antecipação, os símbolos naturais (centrados na pessoa com surdocegueira), comunicação pragmática (em diferentes contextos, para adquirir consciência da linguagem), linguagem simbólica (com a capacidade de utilizar tanto funções conotativas como denotativas dos símbolos).

Outros estudos sobre as discussões de van Dijk foram desenvolvidos desde então, mas importa-nos perceber que, para van Dijk, não há uma metodologia única e sim um conjunto de estratégias metodológicas que precisam ser resgatadas e utilizadas de acordo com as características de cada pessoa, com o uso, por exemplo, do resíduo visual ou auditivo, quando possível. Mas alguns aspectos que deveriam ser universais e "óbvios" para todas as pessoas, em qualquer relacionamento profissional ou pessoal, merecem destaque aqui: antecipação (comunicar e explicar o que irá acontecer e como), comunicação (informar, comentar, falar sobre o que irá acontecer, o que está acontecendo e o que já aconteceu) e respeito (reconhecer limites e diferenças entre as pessoas e aceitar essa diferença sem qualquer julgamento).

O trabalho com pessoas com surdocegueira, deficiência múltipla sensorial ou deficiência múltipla, pode, também, recorrer ao uso de estratégias de planificação. Ao focarem o futuro,

\footnotetext{
${ }^{31}$ Em material disponibilizado pelo Projeto Horizonte, ao descrever "O crescimento da criança não-verbal em direção ao mundo dos símbolos”, Van Dijk lista, antecedendo o nível da ressonância, o afeto. Disponível em: <http://www.ahimsa.org.br/centro_de_recursos/projeto_horizonte/DESENVOLVIMENTO_DA_COMUNICACAO_VAN_DIJK.pdf $\geq$. Acesso em 25/jul/2015.
} 
essas estratégias oferecem importantes subsídios para a educação de pessoas com deficiência múltipla sensorial e surdocegueira - na realidade, para a educação de todas as pessoas. Tratase dos "MAPas" (Making Action Plans, "Fazer Planos de Ação") ${ }^{32}$ e a Planificação Centrada na Pessoa, que convivem, de forma complementar, com os currículos funcionais que partem de inventários ecológicos.

A chegada desses mapas na escola pública municipal de São Paulo acontece com as formações proporcionadas pelas instituições conveniadas à RME. Eles são importantes porque fomentam a criação de uma rede de adultos que convivem com a criança, para trocas e compartilhamento de informações sobre o seu repertório, olhando-se para a pessoa e não para a deficiência. Pode parecer algo simples e fácil de realizar, mas exige exercício e atenção constantes para que não se perca em relatórios médicos e descrições negativas, baseadas no “ideal”.

Nas discussões teóricas, essa ideia da rede de adultos voltará a ser aprofundada quando pensaremos sobre a questão da responsabilidade coletiva e a importância do não isolamento para a realização da ação e efetivação do discurso, conforme pensado por Arendt (2010).

E a discussão sobre metodologias, filosofias de ensino e abordagens não se encerra aqui. Precisa ser ampliada, pois com a perspectiva inclusiva, em nível federal, há uma transformação das antigas EMEES que deixam de ser Escolas Especiais, para transformarem-se em Escolas Municipais de Educação Bilíngue para Surdos (EMEBS) da cidade de São Paulo ${ }^{33}$.

\subsection{AS ESCOLAS MUNICIPAIS DE EDUCAÇÃO BILÍNGUE PARA SURDOS (EMEBS)}

As EMEBS são unidades educacionais da rede pública que atendem crianças, adolescentes, jovens e adultos com deficiência auditiva/surdez. Foram criadas em 10 de novembro de 2011, pelo Decreto n ${ }^{\circ}$ 52.785, substituindo as antigas EMEE.

A inclusão de alunos com surdocegueira ou com deficiência múltipla sensorial começa ainda nas EMEE e continua sendo efetivada nas EMEBS. Nesta parte, assim como nas discussões teóricas do último capítulo, buscaremos apresentar argumentos que permitam a compreensão dessas unidades como modelos inclusivos. Para tanto, propomos reflexões sobre o conceito de inclusão partindo de algumas considerações históricas.

\footnotetext{
${ }^{32}$ Utilizamos como referência um folheto elaborado por Glória Rodriguez, datado de maio de 1999, da California Deaf-Blind Services. Este consta traduzido no Projeto Horizonte (tradução de Shirley R. Maia e Lilia Giacomini) e está disponível em: <http://www.ahimsa.org.br/centro_de_recursos/projeto_horizonte/MAPAS.pdf>. Último acesso em 18/jul/2015.

${ }^{33}$ Em nenhum momento especificaremos qual unidade, a fim de garantirmos o sigilo e anonimato dos profissionais que se voluntariarem para as entrevistas.
} 
Quando pensamos em inclusão como um conceito, e não apenas como uma palavra, buscamos uma separação de sua origem etimológica que remete à clausura. Nesse sentido, inclusão não pode ser compreendido como conformação ou adequação. Recorremos, portanto, ao que Adorno e Horkheimer (1985, p.57-58) pensaram sobre a astúcia de Ulisses:

A astúcia, contudo, consiste em explorar a distinção, agarrando-se à palavra, para modificar a coisa. Surge assim a consciência da intenção: premido pela necessidade, Ulisses se apercebe do dualismo, ao descobrir que a palavra idêntica pode significar duas coisas diferentes. Como o nome Oudeis pode ser atribuído tanto ao herói quanto a ninguém, Ulisses consegue romper o encanto do nome. As palavras imutáveis permanecem fórmulas para o contexto inexorável da natureza.

Isto é, para além da imutabilidade, estamos propondo um agarrar a palavra para modificar a coisa: a inclusão. E como seria possível fazer isso? Um pouco adiante, ao analisarem a fase homérica e a "oposição entre a palavra e aquilo ao qual ela se assimilava", esses autores lembram que essa oposição se torna determinante nessa fase. E é então que:

Ulisses descobre nas palavras o que na sociedade burguesa plenamente desenvolvida
se chama formalismo: o preço de sua validade permanente é o fato de que elas se
distanciam do conteúdo que as preenche em cada caso e que, a distância, se referem a
todo conteúdo possível, tanto a ninguém quanto ao próprio Ulisses. (ADORNO;
HORKHEIMER, 1985, p.58)

É assim que optamos por deixar o sentido de clausura da palavra inclusão e, assim, como com a astúcia de Ulisses, esperamos "romper o encanto do nome" e permitir que a relação entre a palavra e a coisa seja uma relação dinâmica. Assim, deve-se ir contra uma tendência generalizada à simplificação - que é sempre um recurso didático válido, mas acaba por empobrecer as discussões.

O bilinguismo não pode ser estudado como se tratasse do ponto final de uma linha histórica evolutiva que teve um passado oralista. Nem deve ser compreendido como a única resposta possível. A realidade é muito mais rica ${ }^{34}$.

Como ponto de partida, podemos pensar sobre a dificuldade em se saber quais os nomes ou adjetivos corretos a serem utilizados pelas pessoas ouvintes para identificar as pessoas que têm uma perda auditiva. Não é incomum, até mesmo hoje, encontrar ouvintes que não sabem qual termo utilizar. Pessoa com deficiência auditiva? Surdos? Mudos? Ou surdos-mudos?

A grande maioria dos profissionais que atuam com esse grupo, assim como familiares e amigos ouvintes, têm clara consciência de que a surdez não acarreta a mudez. Recentemente, a

\footnotetext{
${ }^{34}$ Não cabe listar todos os estudos existentes, mas importa trazer ao menos três: o de Souza (1998), Lacerda (1998) e Silveira Bueno (2011), que apresentam uma reflexão mais complexa sobre as diferentes abordagens e metodologias de forma contextualizada, e a obra de Capovilla e Raphael (2005, p.253-255), que explicita essa complexidade quando se trata das EMEBS de São Paulo.
} 
própria Comunidade Surda passou a utilizar as redes sociais e a mídia para esclarecer as pessoas em geral sobre essa questão. Basta ver a campanha "apague esta ideia" em que cartazes com a expressão surdo-mudo trazem o termo "mudo" rasurado.

Além da questão do uso incorreto da palavra "mudo", é necessário ressaltar o fato de que, com o reconhecimento da Libras como língua e com a disseminação da utilização da mesma, apesar das pessoas com deficiência auditiva poderem falar, a não oralização - falar utilizando a voz - passou a ser um direito. Portanto, não se trata de uma “evolução" metodológica e nem de uma incapacidade, e sim de uma opção.

A partir do momento em que o bilinguismo é proposto, compreendendo-se o domínio da Libras como primeira língua, e do português, na modalidade escrita, como segunda língua, não oralizar passa a ter um caráter político e não se trata de uma incapacidade e, o mais importante, deixa - ou deveria deixar - de ser uma desvantagem. Este é um aspecto relevante quando pensamos nas pessoas com deficiência auditiva de forma mais ampla, pois há grupos, dentro desse conjunto de pessoas, que defendem o oralismo e que não se identificam como Surdos ${ }^{35}$. Já na década de 1960, Goffman (2008, p.33) alertava para o fato de que:

Os grupos de ação que servem à mesma categoria de pessoas estigmatizadas podem, às vezes, estar em ligeira oposição uns em relação aos outros e essa oposição frequentemente reflete uma diferença entre a direção a cargo dos "nativos" e a direção a cargo dos normais.

E esse autor traz uma citação de Warfield, que desenvolve essa questão ao apresentar as discussões em torno dos rótulos e dos termos, pensados a partir das redes de ajuda mútua, ligas e outras formas de organização, que implicam em categorização, mas de forma positiva na medida em que implicam na "formação de grupo mas sem que seu conjunto total de membros constitua um grupo" (GOFFMAN, 2008, p.33):

\begin{abstract}
Atuando segundo essa crença, o corpo de membros da Liga [Liga Nova-Iorquina para as Pessoas com Dificuldades de Audição] concordou em só usar certos termos, como pessoa com dificuldades de audição, com audição reduzida ou com perda de audição, e em eliminar a palavra surdo de suas conversas, correspondência e outros escritos, de seu trabalho de ensino e de seus discursos em público. O procedimento deu resultado. A cidade de Nova York em geral começou gradualmente a usar o novo vocabulário. [...] (WARFIELD, 1948, p.78, apud GOFFMAN, 2008, p.33-34) (W6 $^{36}$
\end{abstract}

\footnotetext{
${ }^{35}$ A legislação é clara nesse sentido. O decreto n ${ }^{\circ} 5.296$, de 02 de dezembro de 2004, especifica deficiência auditiva como sendo a "perda bilateral, parcial ou total, de quarenta e um decibéis (dB) ou mais, aferida por audiograma nas frequências de $500 \mathrm{HZ}, 1.000 \mathrm{HZ}, 2.000 \mathrm{HZ}$ e 3.000 HZ." Porém, quando se trata da Libras, a lei no 10.436 , de 24 de abril de 2002, especifica no seu parágrafo único: "Entende-se como Língua Brasileira de Sinais - LIBRAS a forma de comunicação e expressão, em que o sistema linguístico de natureza visual-motora, com estrutura gramatical própria, constituem um sistema linguístico de transmissão de ideias e fatos, oriundos de comunidades de pessoas surdas do Brasil." [grifo nosso]

${ }^{36}$ Warfield, F. Keep Listening. Nova York: The Vicking Press, 1955, p.78.
} 
O estudo de Warfield remete a um período caracterizado como oralista, antes da publicação de Stokoe, em 1960, de Sign Language structure, que revolucionou as discussões em torno das línguas de sinais e da Comunidade Surda (SACKS, 1998, p.88-89). Porém, é importante notar que, ainda hoje, principalmente nos Estados Unidos, há uma série de instituições e redes de ajuda voltados para os que têm dificuldade de audição, e estas geralmente estão separadas daquelas que têm os Surdos como público e membros.

Nas redes sociais do Brasil, há grupos de "Deficientes Auditivos" ou "Surdos oralizados", e grupos de "Surdos". Souza (1998, p.105), há quase vinte anos, registrou suas observações sobre as discussões relacionadas a essas divergências, presentes entre os surdos brasilei$\operatorname{ros}^{37}$. Isto é, antes do reconhecimento da Libras como língua. Vale reproduzirmos suas considerações:

Compreensivelmente líderes surdos, principalmente aqueles oralizados, temem que a proposta bilíngue elimine de vez o direito do surdo a ter acesso à oralidade, o que os distanciaria dos próprios pais. Outros surdos, também líderes, esses em geral não oralizados, defendem que o mais importante é o acesso à escrita e citam o modelo sueco como exemplo de democracia e respeito pelo surdo, enquanto, como dizem, membro de uma minoria. (SOUZA, 1998, p.104)

Um pouco posterior, o material publicado pelo MEC (MINISTÉRIO DA EDUCAÇÃO, 2006c, p.19-20) é muito rico em vários aspectos, apesar de já contar com dez anos. Porém, peca ao propor uma diferenciação entre parcialmente surdo (com deficiência auditiva - DA) e surdo restrita ao grau de perda auditiva, sem levar em consideração os estudos sobre a Comunidade Surda - e por isso mantivemos surdo com minúscula. E neste ponto, concordamos com Skliar (2013) que defende que é necessário "discutir a educação bilíngue numa dimensão política", pois a Comunidade Surda precisa ser compreendida como uma minoria cultural.

A complexidade da questão se evidencia, ainda, quando resgatamos um exemplo de um passado mais remoto. Referimo-nos ao caso do padre Juan Pablo Bonet, que em 1620 publicou uma obra dividida em dois livros intitulados Reduction de Las Letras y Arte para Enseñar a Ablar los Mudos $^{38}$. Esse padre é frequentemente citado dentro de uma categoria oralista ou, às vezes, multissensorial, mas pouco se questiona ou se discute o fato de se tratar de um padre, em pleno século XVII, publicando um método voltado para o ensino de "mudos" - isto é, com uma

\footnotetext{
${ }^{37}$ E aqui mantivemos surdos com a inicial minúscula, porque seu estudo abrange não apenas a Comunidade Surda, mas também surdos oralizados, entre outros.

${ }^{38}$ A obra de Bonet está disponível, página a página, no site da Universidad de Sevilha (disponível em: <http://fondotesis.us.es/fondos/libros/91/8/reduction-de-las-letras-y-arte-para-ensenar-a-ablar-los-mudos/>. Último acesso em 18 jul. 2011), e também na Biblioteca Digital Hispanica (disponível em: <http://bibliotecadigitalhispanica.bne.es/view/action/>. Último acesso: 18 jul. 2011) em um total de 363 imagens.
} 
ênfase na mudez. Portanto, é importante uma reflexão historiográfica para não ficarmos presos aos mesmos ciclos de discussões.

Quando Bonet imprimiu sua obra, a Espanha era regida pelas Ordenações Filipinas, também válidas em Portugal, pois vigorava a União Ibérica (1580-1640). A leitura dessas leis nos permite perceber as necessidades das pessoas com deficiência auditiva, de famílias nobres, no século XVII: a ênfase na mudez tinha relação direta com a aptidão para testemunhar em testamentos e a fazer testamento. Essa mesma questão foi levantada em outro trabalho (EMI, 2011, p. 16-7) a partir da reprodução do seguinte excerto:

Hoje [...] os indivíduos nestas condições aprendem a ler e escrever, parece que se torna
inapplicavel para esses a nossa Lei, visto como, segundo a razão da mesma Lei, podem
taes surdos-mudos expressar sua vontade por meio da escripta. Entretanto a letra da
lei, que neste caso luta com o seu espírito, he muito positiva excluindo os surdos-
mudos de nascença do direito de testarem. (ORDENAÇÕES FILIPINAS, Livro 4,
Títulos LXXXI e LXXXV apud EMI, 2011, p.17-18)

E é interessante notar onde essa lei pretende abrir uma brecha: aos que "aprendem a ler e escrever”. Isto é, assim como o modelo bilíngue que prevalece atualmente no Brasil, remete à modalidade escrita como prioridade, e não à fala, evidenciando como algo que para muitos parece revolucionário, reproduz um modelo de cerca de quatrocentos anos.

Poder-se ia questionar: mas é apenas o texto de uma lei. Sim, mas se as leis não determinam de forma universal as ações e atitudes das pessoas, ao menos servem como uma fresta para vislumbrarmos características objetivas do passado. Deve se compreender que mesmo as leis, em diferentes contextos históricos, estavam relacionadas a grupos específicos. Isto é, até o século XVIII, os direitos políticos eram privilégios. Analfabetos e mulheres, por exemplo, não eram considerados cidadãos, não tinham direito ao voto e não tinham acesso à educação acadêmica formal. Estas são conquistas posteriores à elaboração das constituições republicanas e democráticas modernas. Quando, à questão do gênero, somavam-se aspectos sociais como a pobreza, ou características físicas como alguma deficiência, ou culturais, como a adesão a alguma religião que não a majoritária, a situação de vulnerabilidade crescia exponencialmente e isso refletia na expectativa de vida dessas pessoas. Portanto, deve-se ter em mente, a todo momento, os contextos. Nesse sentido, não podemos esquecer que Bonet redigiu sua obra para um

\footnotetext{
${ }^{39}$ Elaboradas do final do século XVI, as Ordenações Filipinas somente entraram em vigor em 1603 e eram baseadas nas Ordenações Manuelinas. O texto integral está disponível no site: <http://www1.ci.uc.pt/ihti/proj/filipinas/ordenacoes.htm>. Acesso em 21 de julho de 2011.
} 
público específico: não eram todos os "mudos", mas somente os descendentes de famílias nobres. Souza (1998, p. 130) reforça nossas considerações e amplia a questão ao nos trazer mais dados:

\begin{abstract}
Até 1760 apenas surdos provenientes de famílias abastadas tinham acesso à educação. Cada tutor desenvolvia sua própria práxis pedagógica e a guardava em absoluto segredo. Um segredo que, quando convertido em sucesso, conferia fama e muito dinheiro a quem o dominasse. Sucesso, por sua vez, que se traduzia em conseguir que o surdo escrevesse e lesse mais do que em fazê-lo falar.
\end{abstract}

Sim: apenas surdos de famílias abastadas ${ }^{40}$. Mas então, Souza nos fala sobre o sigilo em torno das práticas pedagógicas e nos leva de novo à pergunta: o que faz com que Bonet publique uma obra sobre o método de ensino para surdos? E agora, podemos detalhar a mesma: o que faz com que Bonet publique uma obra sobre o método de ensino para surdos quando esse conhecimento era tão caro?

Uma análise do universo "editorial" de então oferece pistas suficientes para uma discussão sobre a questão, como já desenvolvido no estudo referido anteriormente (EMI, 2011). Importa focarmos o que Souza apresenta sobre a restrição do acesso à educação às crianças de famílias ricas. Isto porque a redução da análise histórica apenas à perda auditiva faz com que muitos outros aspectos, como os sociais e de classe, sejam ignorados. No Brasil, isso implicaria em uma falha grave, pois o acesso à educação formal, seja em um modelo oralista, seja com a Libras como primeira língua, está, não raras vezes, relacionado à classe social e à possibilidade financeira das famílias pagarem por atendimentos especializados ou até mesmo de terem acesso às informações.

Silveira Bueno pode ser trazido novamente, pois já alertou para esse fato ao apresentar observações sobre a ampliação da rede privada de atendimento ao excepcional. Esse autor evidenciou o aumento da importância dessas entidades e explica:

\begin{abstract}
A segunda característica marcante dessa ampliação foi a distinção crescente entre as entidades filantrópico-assistenciais, que se dirigiram à população deficiente oriunda dos extratos mais baixos da classe média e das classes baixas, e as empresas prestadoras de serviços de reabilitação e educação voltadas à população de poder aquisitivo elevado e que, no âmbito da educação especial, representou a concretização do processo de privatização que ocorreu no país nos campos da saúde e da educação. Essa distinção deixa patente que, enquanto os excepcionais das camadas populares continuavam sendo objeto da assistência e caridade públicas, passou-se a oferecer aos excepcionais das elites serviços que garantiam seus direitos em relação à saúde $e$ educação. [grifo nosso] (SILVEIRA BUENO, 2011, p.111-112)
\end{abstract}

\footnotetext{
${ }^{40}$ Nesta parte da discussão, mantivemos surdos com inicial minúscula, pois não conseguimos visualizar uma organização por parte dos surdos, como uma comunidade, e sim uma imposição de um espaço socialmente privilegiado.
} 
Portanto, trata-se de vulnerabilidade social em uma sociedade regida pela lógica do privado, onde, geralmente, quem pode pagar, tem acesso aos atendimentos e serviços - escolas, atividades extra-curriculares como dança e outros esportes, terapias fonoaudiológicas, psicoterapias, entre outros. Um cenário que, como notou Caldeira (2000) já nas últimas décadas do século XX, forja uma sociedade muito mais segregada e desigual.

É neste ponto que as EMEBS, como escolas públicas e gratuitas, têm um papel essencial quando pensamos em valores como democracia e direitos.

Ressalte-se que, nos últimos vinte anos, houve uma rica produção acadêmica voltada à questão da Surdez. Maria Cecília de Moura, Fernando Capovilla, Ronice Müller de Quadros, Regina Maria de Souza e Cristina Broglia Feitosa de Lacerda, são alguns dos pesquisadores que vêm destacando a importância das línguas de sinais, mais especificamente da Língua de Sinais Brasileira (Libras), assim como da educação bilíngue para Surdos. Muitos desses estudos tiveram uma participação direta ou indireta nas ações que levaram ao reconhecimento da Libras pela Lei Federal no 10.436, de 24 de abril de 2002, como meio legal de comunicação e expressão. Portanto, restringiremos nossas considerações sobre a questão a esses breves apontamentos, buscando focar o tema específico que nos propomos a estudar.

Sendo assim, vale apresentarmos uma nova questão que permeou as discussões deste estudo: em se tratando de pessoas com surdocegueira, a importância de se compreender que cada um é único, exige outros requisitos dos educadores que vão recebê-los? E em caso afirmativo, quais requisitos são esses?

Atuar com alunos com surdocegueira não diz respeito apenas a aprender ou saber uma outra língua, no caso, a Libras. Afinal de contas, há uma série de outras formas de comunicação que precisam ser considerados: há pessoas com surdocegueira ou deficiência múltipla sensorial que utilizam Libras Tátil ${ }^{41}$, outras recorrem ao Tadoma ${ }^{42}$. Há, ainda, pessoas que usam o alfabeto datilológico ou a escrita alfabética na palma da mão ${ }^{43}$. Algumas pessoas com surdocegueira ou deficiência múltipla sensorial congênita, sem uma linguagem simbólica, necessitam

\footnotetext{
${ }^{41}$ Libras tátil consiste no uso da Língua Brasileira de Sinais com as mãos do receptor sobre as mãos daquele que enuncia a informação, ficando seu polegar entre a palma e o polegar desse receptor.

42 Tadoma: geralmente utilizado mais por pessoas com surdocegueira pós-linguística e com resíduo auditivo. A pessoa com surdocegueira coloca o polegar na frente (no canto) dos lábios do interlocutor ou intérprete, os demais dedos ficam estendidos sobre a face, o maxilar e o pescoço. O mindinho, no pescoço, fica próximo à região das cordas vocais para captar as vibrações durante a fala.

43 A escrita alfabética na palma da mão implica exatamente em escrever as letras, geralmente na forma bastão, sobre a palma da mão da pessoa com surdocegueira. Geralmente utilizado por pessoas com surdocegueira póslinguística que já haviam sido alfabetizados.
} 
de formas de comunicação que recorrem a objetos de referência ${ }^{44}$, partes de objetos e/ou fotografias. Há, inclusive, crianças surdas que conseguem organizar as rotinas com músicas. Não há, pois, uma única solução pedagógica, independentemente do tão ansiado diagnóstico clínico. Isto é, não há uma especialização com receitas de como fazer, nem do que fazer. Há, sim, conhecimentos consolidados por profissionais que contam com anos de atuação, principalmente em instituições especializadas ${ }^{45}$, voltadas para garantir, em primeiro lugar, a autonomia e a independência na locomoção - orientação e mobilidade - nas atividades de vida diária, entre outros aspectos que invadem todos os espaços frequentados pelo aluno, e também, o desenvolvimento acadêmico e o aprendizado de tudo o que envolve sua presença no mundo, não apenas na escola, mas também na casa, na igreja, na lanchonete, na casa do amigo ou da amiga, entre outros espaços públicos e privados. Então, de qual formação de professores estamos falando?

Quando se nota como as possibilidades de formas de estar no mundo são infinitas, parece-nos evidente que a verdadeira especialização implica em uma formação de pessoas predispostas a enxergar a diferença e aceitá-la plenamente. E aceitar significa estar presente, com disponibilidade para aprender e com uma tendência à criação e à libertação de rotinas, o que é de certa forma, irônico e contraditório, já que muitas dessas rotinas são essenciais para a organização das atividades das crianças com surdocegueira ou com deficiência múltipla sensorial. Talvez fique mais claro se afirmarmos que é necessário perceber a diferença entre o que é uma "rotina padrão" ou "ideal”, imposta de forma automática, e as rotinas significativas, construídas com a criança, com a participação dos familiares, com os demais colegas da sala, entre outros. E, como já foi apontado mais de uma vez, essa possibilidade, esse olhar diferenciado, deveria se estender a todas as crianças e a todas as pessoas. Não há um recurso metodológico, uma abordagem de ensino que seja absoluta e universalmente eficaz. Cada método tem um objetivo específico e serve para os fins elegidos - seja o preparo para o vestibular, seja a capacitação para o trabalho, seja a formação de cidadãos críticos. E é essa eleição de fins para a educação que têm provocado várias questões. Como Adorno (1995, p.140) nos lembra, citando Hegel, havia tempo em que o conceito de educação era substancial e compreensível por si mesmo, a partir da totalidade de uma cultura. Com essa afirmação, esse autor nos alerta para a gravidade de uma sociedade que lança a questão: "Educação - para quê?"

\footnotetext{
44 "Objetos de referência são objetos que têm significados especiais associados a eles. Eles estão para alguma coisa, praticamente da mesma forma que as palavras." Tradução de Sylvia Miguel, do texto Objects of Reference, de Adam Ockelford.

${ }^{45}$ Pois, tradicionalmente, no Brasil, eram essas instituições que recebiam a atendiam pessoas com deficiência.
} 
Um pouco adiante, Adorno (1995, p.141) traz uma reflexão que evidencia como nossas colocações nada têm de original. Pelo contrário, chegam a parecer conservadoras quando percebemos que já em 1966, Adorno afirmava que a Educação não deve ter um fim, um objetivo. O conceito criticado por ele é o de "modelo ideal (Leitbild)", e para discuti-lo, oferece-nos uma reflexão importante sobre a heteronomia:

[...] o momento autoritário, o que é imposto a partir do exterior. Nele existe algo de usurpatório. É de se perguntar de onde alguém se considera no direito de decidir a respeito da orientação da educação dos outros. As condições - provenientes do mesmo plano de linguagem e de pensamento ou de não-pensamento - em geral também correspondem a este modo de pensar. Encontram-se em contradição com a ideia de um homem autônomo, emancipado, conforme a formulação definitiva de Kant na exigência de que os homens tenham que se libertar de sua auto-inculpável menoridade. (Adorno, 1995, p.141)

Vale destacar que, novamente, quando pensamos sobre a heteronomia, com a criação das escolas bilíngues públicas e a inclusão dos alunos com surdocegueira nas mesmas, não há mais necessidade de, como Helen Keller, preocuparem-se em dedicar horas e horas para sentir, por meio do tato, a vibração da garganta, o movimento dos lábios e da língua, e o movimento facial, com o intuito de aprender a falar. Pelo contrário. Com a inclusão de alunos com surdocegueira ou com deficiência múltipla sensorial, e com as formações oferecidas pela SME ou por profissionais das instituições conveniadas, as estratégias centradas em cada aluno passam a ser dominados por um novo olhar. E o mais interessante, esse novo olhar não deixa de aceitar a possibilidade de trabalhar a oralidade, com um fonoaudiólogo, quando determinado aluno demonstra interesse nesse sentido - mas neste caso, esse atendimento fonoaudiológico cabe à área de saúde, e não à educação.

A opção pelas EMEBS, para a inclusão desses alunos, se deu porque a Libras Tátil ou o uso da datilologia sobre a palma da mão do interlocutor, entre outras formas de comunicação, mostrava-se como um aprendizado mais fácil e possível para profissionais fluentes em Libras - hipótese esta que também foi desenvolvida no decorrer dos capítulos. Porém, o mais importante, e que devemos ter em mente para a compreensão desta dissertação: trata-se de uma narrativa sobre a chegada de alunos com surdocegueira, na rede pública, mais especificamente na RME de São Paulo, e que aconteceu nas EMEBS. 


\subsection{PLANOS INDIVIDUALIZADOS: UM CAMINHO PARA A EQUIDADE}

A predominância de estudos de caso nos estudos acadêmicos existentes sobre a surdocegueira aponta para uma questão que nos parece ser central: sendo a equidade um princípio defendido pela Política Nacional de Educação Especial na Perspectiva da Educação Inclusiva, os estudos de caso refletem um cenário marcado pelo respeito à singularidade. Mais do que uma linha metodológica, retrata uma mudança na visão de mundo, uma libertação de padrões e buscas de semelhanças ou regras, para um olhar focado na riqueza do singular. Acreditamos que isso representa a opção em busca da equidade.

Assim como os estudos de caso, os planos individualizados ${ }^{46}$, muitas vezes identificados como plano de desenvolvimento individualizado ou individual (PDI), ou ainda, como programa educativo individual (PEI), estão centrados no(a) aluno(a) e exigem uma equipe para sua elaboração. Não se trata de uma equipe presencial de profissionais das mais diversas áreas, mas quando há uma rede forte onde os terapeutas mantém uma relação dialógica com a família e os especialistas das instituições conveniadas, das SAAI, e/ou com as PAAI, e estes com os professores que estão diariamente na sala de aula com o(a) aluno(a), é possível elaborar um plano que estabeleça metas específicas e possíveis.

Há planos que apontam para currículos funcionais, que conversam muito bem com os parâmetros curriculares nacionais (PCN), de forma mais ampla, quando se pensam os diferentes conteúdos escolares do currículo regular, e de forma mais pontual, porque há um volume dos PCN voltado particularmente para as "Adaptações Curriculares: estratégias para a educação de alunos com necessidades educacionais especiais", onde um dos capítulos, intitulado "Adaptações Individualizadas no Currículo”, faz referência ao PDI. Mas tendo em vista que os parâmetros são exatamente o que o nome diz, e que há certa maleabilidade no trabalho com os conteúdos, os PDI devem condizer com a realidade de cada aluno - e não seria ideal que fosse utilizado com todos os alunos?

Deve se atentar para o título "Adaptações Individualizadas no Currículo", isto é, no currículo e não do currículo. Esse é um aspecto que, no caso da inclusão, quando se conhece uma instituição, há uma tendência a se pensar no atendimento educacional especializado como modelo, com atividades e conteúdos próprios e distintos da turma. Entretanto, na sala de aula, em

\footnotetext{
${ }^{46}$ Interessa notar que grandes empresas vêm utilizando o Plano de Desenvolvimento Individualizado (PDI), dentro de outra concepção de formação, apesar da coincidência do nome, como instrumento de planejamento de carreira. Seria necessária uma análise mais atenta desse cenário para compreender as origens, as características e o uso desse instrumento nesses outros cenários, mas vale atentar para as etapas do PDI em ambiente corporativo, desde a avaliação até o feedback.
} 
uma perspectiva inclusiva, o aluno deve participar das atividades com os colegas, compartilhando o mesmo currículo. Não se trata de criar um novo currículo, mas de adaptar a forma, que exige muito mais funcionalidade e contextualização. Por exemplo, sendo o conteúdo matemática, pode ser utilizada uma receita para que haja uma contagem real e contextualizada, o que propicia a compreensão do que é o número e a soma, não apenas pelo aluno com surdocegueira, mas por todos os alunos.

Essa observação é importante porque em seu estudo, Cormedi (2011, p.145-147) notou que para os professores, currículo e programa educativo individual eram sinônimos. Erro este muito comum.

Quando se pensa em alunos com surdocegueira, se eles dominam a leitura e escrita do braile, e alguma forma de comunicação como o Tadoma ou a Libras tátil, a única adaptação necessária é a do material.

Tomando novamente o exemplo de Helen Keller para pensarmos sobre essa discussão, em sua biografia, ela nos dá uma noção do que é o currículo estudado na faculdade:

Meus estudos no primeiro ano foram francês, alemão, história, composição de inglês
e literatura inglesa. No curso de francês li alguns trabalhos de Corneille, Molière, Ra-
cine, Alfred de Musset e Sainte-Beuve, e no de alemão, os trabalhos de Goethe e
Schiller. Passei rapidamente em revista todo o período da história da queda do Império
Romano ao século XVIII, e na literatura inglesa estudei criticamente os poemas de
Milton e a Aeropagitica. (KELLER, 2008, p.93-94)

Isto é, um currículo invejável e inalcançável para muitos ouvintes e videntes. Ler Molière em francês e Goethe em alemão? Portanto, a elaboração de um PDI não significa "facilitar" e "simplificar", pois ter uma deficiência não significa ter mais dificuldade que os outros. Elaborar um PDI significa compreender as potencialidades e especificidades de cada um. E, novamente, cabe a questão: não seria o ideal para todos os alunos e todas as alunas?

Além disso, poderíamos pensar como tantos adolescentes questionam "para que estudar a história de Roma"? Isso evidencia a necessidade de se ter clareza do direito ao acesso a currículos amplos, que abarquem diferentes temáticas e contextos, mesmo que a partir da aprendizagem os alunos decidam que se trata de um discurso opressor ou colonialista. A verdadeira crítica só é possível a partir do conhecimento.

Arendt (2011, p.260-261), em “A Crise na Cultura”, provoca uma reflexão sobre esse aspecto:

A cultura relaciona-se com objetos e é um fenômeno do mundo; o entretenimento relaciona-se com pessoas e é um fenômeno da vida. Um objeto é cultural na medida em que pode durar; sua durabilidade é o contrário mesmo da funcionalidade, que é a qualidade que faz com que ele novamente desapareça do mundo fenomênico ao ser usado e consumido. O grande usuário e consumidor de objetos é a própria vida, a vida 
do indivíduo e a vida da sociedade como um todo. A vida é indiferente à qualidade de um objeto enquanto tal; ela insiste em que toda coisa deve ser funcional, satisfazer alguma necessidade. A cultura é ameaçada quando todos os objetos e coisas seculares, produzidos pelo presente ou pelo passado, são tratados como meras funções para o processo vital da sociedade, como se aí estivessem somente para satisfazer alguma necessidade - e nessa funcionalização é praticamente indiferente saber se as necessidades em questão são de ordem superior ou inferior.

E nesse sentido, os museus paulistanos que vêm promovendo a acessibilidade são de extrema importância. Sim, a funcionalidade e a contextualização são importantes para todo e qualquer aluno, mas a fruição, o relacionamento com objetos que não têm "função", também deve fazer parte dos planos, seja individualizado, seja de uma turma de quarenta alunos. Relacionar-se sem consumir: explorar uma escultura com o tato, ouvir ou sentir a vibração de uma música, conhecer e ter experiências. Relacionar-se, ainda que seja para notar a exclusão, a ausência de uma representação de si mesmo e então, exigir a própria presença, como o fez Dalton Paula em sua série de pinturas em óleo sobre a capa de enciclopédias, de 2010, intitulada $R e$ trato Silenciado. Segundo suas próprias palavras (PAULA, 2014), uma produção que "perpassa basicamente a temática do corpo silenciado" e que traz uma resposta nova, ao propor o uso da capa da enciclopédia, uma publicação que visa a "sistematização e materialização do conhecimento científico", como um novo suporte para a inclusão daqueles que não estão entre as suas páginas.

Portanto, relacionar-se para perceber-se, e perceber-se leva à capacidade de agir e discursar, direitos que devem ser garantidos a todos, em sua peculiaridade e em sua maneira de estar no mundo. Somente assim, poderemos falar em equidade: o reconhecimento de direitos que garantam o acesso de todos a todos os espaços, respeitando-se a pluralidade e a singularidade - e esses conceitos, conforme pensados por Arendt (2010, p. 219-220). 


\section{A EDUCAÇÃO EM TEMPOS DE SEMIFORMAÇÃ̃ ${ }^{47}$}

No início, quando a professora contava sobre uma coisa nova, eu fazia muito poucas perguntas. Minhas idéias eram vagas e meu vocabulário inadequado; mas à medida que meu conhecimento das coisas crescia e eu aprendia cada vez mais palavras, meu campo de interrogações se ampliou e eu voltava repetidamente ao mesmo assunto, ávida por mais informação. Às vezes uma palavra nova revivia uma imagem que alguma experiência anterior gravara no meu cérebro.

Lembro-me da manhã em que perguntei pela primeira vez o significado da palavra "amor". Isso foi antes que eu conhecesse muitas palavras. Eu encontrara algumas violetas precoces no jardim e as trouxera para a srta. Sullivan. Ela tentou me beijar mas naquela época eu não gostava que ninguém me beijasse, exceto minha mãe. A srta. Sullivan me abraçou gentilmente e soletrou na minha mão:

- Eu amo Helen.

- O que é amor? - perguntei.

Ela me puxou mais para perto e disse:

- Está aqui - apontando para o meu coração, de cujas batidas tive consciência pela primeira vez.

Suas palavras me intrigaram muito, porque no momento eu não entendia nada que eu não tocasse.

Senti o cheiro das violetas em sua mão e fiz, meio em palavras meio em sinais, uma pergunta que significava:

- Amor é a doçura das flores?

- Não - disse a srta. Sullivan.

Pensei novamente sobre o assunto. O sol quente brilhava sobre nós.

- Isso não é amor? - perguntei, apontando na direção de onde vinha o calor. - Isso não é amor?

Eu achava que não poderia haver nada mais bonito que o sol, cuja tepidez faz todas as coisas crescerem. Mas a srta. Sullivan sacudiu a cabeça e fiquei muito intrigada e desapontada. Achei estranho que minha professora não pudesse me mostrar o que era amor.

Um ou dois dias depois, eu estava enfiando contas de diferentes tamanhos em grupos simétricos num fio - duas contas grandes, três pequenas, e assim por diante. Cometera muitos erros, e a srta. Sullivan os apontava repetidamente, com uma suave paciência. Finalmente notei um erro muito óbvio na sequência e, por um instante, concentrei minha atenção na aula e tentei pensar como devia ter arrumado as contas. A srta. Sullivan tocou minha testa e soletrou com decidida ênfase:

- Pense.

Num relâmpago, eu soube que a palavra era o nome do processo que estava acontecendo em minha cabeça. Essa foi a minha primeira percepção consciente de uma idéia abstrata.

Fiquei parada por um longo tempo - não estava pensando nas contas no meu colo, e sim tentando entender um significado para "amor" à luz daquela nova idéia. $\mathrm{O}$

\footnotetext{
47 O título deste capítulo, "A Educação em Tempos de Semiformação", resgata o termo que dá título ao texto original de Adorno, "Theorie der Halbbildung". Há traduções que optam por pseudoformação para Halbbildung. Aqui, nossa escolha por semiformação se justifica pelo fato de acreditarmos em uma incompletude - halb possui a mesma origem etimológica de half em inglês, que significa uma parte, uma metade que não são necessariamente duas metades iguais - e não em uma falsidade, como o termo pseudo nos leva a pensar (IRMEN; KOLLERT, 1995, p.841). Bildung, por sua vez, pode ser traduzido como educação, formação, instrução e cultura (IRMEN; KOLLERT, 1995, p.721). Optamos por formação, para evitar confusões com o termo educação, muitas vezes associado apenas à formação acadêmica, assim como ocorre com o termo instrução. Descartamos a tradução "semicultura", por sua vez, por ser comumente associado a aspectos relacionados às artes, ao teatro, à música, entre outros elementos que compõem um tipo de formação que, no Brasil, acaba por ser vinculado a um determinado comportamento ou classe social. Some-se a isso o fato de compreendermos formação como algo que supera o espaço acadêmico, conectando as esferas públicas e privada, e que passa a ser constitutiva dos sujeitos.
} 
sol tinha estado encoberto o dia todo e alguns rápidos aguaceiros já haviam desabado; mas subitamente o sol irrompeu de novo em todo seu esplendor do Sul.

Mais uma vez perguntei à minha professora:

- Isso não é amor?

- Amor é algo como as nuvens que estavam no céu antes do sol aparecer respondeu ela. Então, em palavras mais simples do que essas, que naquela época eu não poderia ter entendido, ela explicou: - Você sabe que não pode tocar as nuvens, mas sente a chuva e sabe como as flores e a terra sedenta ficam contentes de recebêla depois de um dia quente. Da mesma forma, não pode tocar o amor, mas sente a doçura que ele derrama em tudo. Sem amor, você não seria feliz nem ia querer brincar. A bela verdade irrompeu em minha mente - senti que havia linhas invisíveis estendidas entre meu espírito e o espírito dos outros. [grifo nosso]

(Keller, 2008, p.28-30)

O texto trazido como epígrafe para a presente discussão teórica também foi retirado da biografia de Helen Keller e é importante por remeter à ideia de emancipação, presente tanto em Adorno (1995) como em Arendt (2004), quando resgatam o horror do nazismo para falar sobre a formação de pessoas autônomas.

Arendt (2004, p.166) chama a atenção para a importância e necessidade de pensar e lembrar. Já Adorno (1995, p.170) acredita na necessidade "de uma oferta formativa bastante diferenciada e múltipla, em todos os níveis”. Pensamento e multiplicidade.

Não espanta o fato de que a primeira ideia abstrata que Helen Keller consegue perceber conscientemente é o processo que estava acontecendo em sua cabeça: o pensamento. E também parece muito óbvio quando Helen Keller afirma que "à medida que meu conhecimento das coisas crescia e eu aprendia cada vez mais palavras, meu campo de interrogações se ampliou e eu voltava repetidamente ao mesmo assunto, ávida por mais informação.”

Mas no trabalho educacional com pessoas com surdocegueira, a comunicação passa a ser um tema recorrente e que não pode ser deixado de lado, porque sem comunicação, não há formação possível.

Anne Sullivan já havia estabelecido uma comunicação com Helen Keller, que já tinha um considerável repertório de palavras, quando houve o questionamento: o que é amor? Sendo assim, a professora utilizou recursos como a descrição e a exemplificação, trazendo esse repertório anterior, para responder a Helen. E esse repertório era necessário para a educação; e ele próprio já é componente da educação.

Comunicação tem relação com a ação comum: communis + actio. E essa ação comum é requisito para a educação. Quando a teoria de van Dijk traz as estratégias de ressonância e de movimentos coativos, é de estratégia comunicativa que se está falando.

A educação encontra barreiras quando não se fala a mesma língua - e não só o idioma, mas até os regionalismos e aspectos culturais podem interferir no bom andamento dessa ação 
comum. Quando essas barreiras não são notadas, a educação pode ter a aparência de educação, mas ser apenas memorização ou ocorrer de forma distorcida, dando-nos a ilusão de missão cumprida, mas sequer chegando às falsas concepções de educação criticados por Adorno (1995, p.141) de "mera transmissão de conhecimentos" ou de "modelagem de pessoas".

É na necessidade de um código comum que reside a importância das palavras, não apenas as verbais, mas também as escritas, as soletradas em alfabeto manual, as sinalizadas, as concretizadas em objetos de referência, as desenhadas, entre outros. Elas são o requisito para a educação, para que se possa apresentar o mundo que representam e no qual estamos. Como nos lembra Vigotski (2009, p.409), “o pensamento não se exprime na palavra mas nela se realiza”.

Em suas cartas, Anne Sullivan (Keller, 2008, p.295) registra que, no início, Helen Keller aprendia muitas palavras e as soletrava, mas não sabia usá-las, como se a soletração fosse uma sequência de movimentos manuais a ser decorado. Mas somente quando Helen Keller realmente compreende que a sequência $a+g+u+a$ representava a água, coisa, de forma individual e distinta da caneca ou leite, "uma nova luz surgiu em seu rosto". Ao compreender que aqueles movimentos, naquelas sequências específicas, correspondiam ao nome das coisas, Helen Keller passa a perguntar o nome de tudo, deixando de fazer a soletração apenas como uma atividade automatizada.

É possível arriscar uma associação com as palavras de Adorno (1996, s/p), parafraseando sua afirmação: Helen Keller deixa o "estado informativo pontual, desconectado, intercambiável e efêmero, e que se sabe que ficará borrado no próximo instante por outras informações" para permitir a constituição de sua subjetividade por meio da experiência e do conceito.

Há inúmeras passagens em sua biografia que poderiam ser trazidas, mas de forma muito resumida, o que Helen Keller nos fala é a exploração incessante da multiplicidade: de tudo e de cada coisa. Esquilos, vivos ou mortos; insetos, vivos ou mortos; flores, plantadas na terra ou em vasos; girinos, na água do aquário e sapos, no chão. Anne Sullivan lhe entregava tudo nas mãos, para explorar, sentir o movimento, quando vivos, sentir o não movimento, quando mortos ou inanimados, acompanhar o crescimento e a transformação, como no caso dos girinos e borboletas, sentir os odores, as texturas. Não havia medo ou nojo. Tudo era apresentado e explorado de forma tátil e pelo olfato; no caso de alimentos, pelo paladar. E a cada nova flor, era dado o nome, o tipo, a cor. A cada nova textura, o adjetivo correspondente. Experiência e conceitos, a todo momento.

Pensamento, multiplicidade, experiência e conceitos. Elementos importantes para educação, mas, como nos lembra Adorno (1996, s/p), pensar a formação de maneira desconectada e isolada, poderia levar à ilusão de que a educação, por si só, acabaria com a exclusão. Contudo, 
a escola não é uma entidade alheia à sociedade. E como pensar sobre o nosso contexto para propor mudanças à escola? Convém partir dos anseios de Adorno em "A Educação contra a Barbárie” (1995, p.165):

Com a educação contra a barbárie no fundo não pretendo nada além de que o último adolescente do campo se envergonhe quando, por exemplo, agride um colega com rudeza ou se comporta de um modo brutal com uma moça; quero que por meio do sistema educacional as pessoas comecem a ser inteiramente tomadas pela aversão à violência física.

Se é necessário pensar de maneira conectada com o mundo, imaginemos isto que Adorno almeja: um sistema educacional que rejeite a violência. Qual a viabilidade de conexão com o mundo?

Apesar de tudo o que se refere, no que diz respeito à violência nas escolas públicas, acreditamos que sim. É possível uma educação que rejeite a violência dentro de um mundo que rejeite a violência. E isso não está tão distante. Um sistema educacional que rejeita a violência, condiz com a educação democrática, principalmente se tomarmos a educação inclusiva como foco - e aqui estamos falando em termos de princípios e valores.

E em termos práticos? Se as palavras são um requisito para a comunicação, necessária para a efetivação da educação, quando, no passado, aqueles que conviviam com pessoas com deficiência pararam para rever como se referiam a elas, mais uma possibilidade de não violência foi criada. Quando elas atentaram para o fato de estarem ou não sendo verbalmente agressivos ou incorretos com esse outro, havia aí uma busca no sentido da superação da dominação. Havia aí, a busca por uma multiplicidade de palavras e conceitos que pudessem ser utilizadas.

As palavras que nos unem para a troca de informações e para a comunicação, também nos mostram que estão se formando possibilidades objetivas de transformação. E educação, como formação, e sociedade, estão originariamente conectadas. Arendt resgata uma discussão presente em Górgias, que traz a mesma aspiração de Adorno, mas na política. “A preocupação política não é saber o que é mais vergonhoso: se o ato de atacar alguém injustamente ou de ser atacado injustamente. A preocupação é exclusivamente com a possibilidade de ter um mundo em que esses atos não ocorram.” (ARENDT, 2004, p.157)

Envergonhar-se com a agressão, ser tomado pela aversão à violência física, no espaço político e no espaço escolar, implica em rejeitar a agressão no espaço público. E isso faz todo o sentido quando não confundimos a finalidade da educação: ela não é para a aprovação em uma universidade. O fim dela é a formação de pessoas para o mundo, e por isso engloba todos os espaços, porque formação não é um objeto que se carrega, mas algo que se incorpora. 
Quando a educação especial passou a ser efetivada em sua perspectiva inclusiva, a preocupação com a não violência verbal foi fortalecida. Pais, profissionais da saúde, professores e pesquisadores, que atuavam com pessoas com deficiência, objetivavam, por meio do cuidado com os termos utilizados, uma consciência - e aqui não questionamos a plenitude da mesma, mas valorizamos sua existência, por mais incipiente que seja.

Na realidade, essa consciência não está na simples preocupação com as palavras. Há estudos de diferentes épocas que, mesmo utilizando expressões hoje consideradas preconceituosas, trazem em si uma postura acolhedora, receptiva e perscrutadora frente ao preconceito real, porque crentes nas possibilidades dos educandos com deficiência. Portanto, enxergamos as palavras como instrumentos que podem nos dar indícios de uma forma de pensamento que busca a autonomia, mas com o cuidado de não nos atermos à sua forma; isto é, atentando para o seu sentido e uso, para as ações ligadas a elas.

A liberdade de escolha, associada ao princípio da aversão à violência, é o que pode realmente fazer diferença. $\mathrm{O}$ uso de clichês, por si só, talvez não represente um preconceito, e sim uma soletração como a de Helen Keller; uma sequência de movimentos manuais ainda sem sentido, que podem ser um passo a caminho da formação. E o que fazer para que o aluno dê esse passo do clichê para a consciência, contra o conformismo vigente? E como fazer com que a soletração de uma sequência de letras se torne um conceito, uma objetivação de algo?

Pelo pensamento.

Anne Sullivan (Keller, 2008, p.319-321) narra, em uma de suas cartas, uma situação em que Helen Keller, aos sete anos de idade, agredia Viney, que trabalhava na residência dos Keller. A professora diz que precisou conter Helen Keller segurando suas mãos e acalmando-a, mas depois, quando esta foi ao seu quarto, triste e tentou dar-lhe um beijo, ela recusou: "Não posso beijar menina levada". Helen tentou se justificar dizendo que é boa, sendo Viney, a má. Mas Anne Sullivan não cedeu: "Você bateu em Viney, chutou-a e a machucou. Você foi muito levada e eu não posso beijar menina levada".

O que se seguiu foi uma insistência de Anne Sullivan, incentivando o pensamento de sua pupila, e merece ser trazido sem recortes:

[Helen] ficou imóvel por um momento e era evidente por seu rosto congestionado e perturbado que travava uma luta em sua mente. Então disse: "Helen não amou (ama) professora. Helen ama mãe. Mãe vai chicotear Viney". Eu lhe disse que era melhor que ela não falasse mais nisso, mas pensasse. Ela sabia que eu estava muito perturbada e teria gostado de ficar perto de mim; mas achei melhor para ela ficar sozinha. À mesa do jantar ela ficou profundamente tocada porque eu não comi e sugeri que "cozinheira faz chá para professora". Mas eu lhe disse que meu coração estava triste e não tinha vontade de comer. Ela começou a chorar, a soluçar e se agarrou a mim. 
Estava muito agitada quando subimos; então tentei interessá-la num curioso inseto chamado bicho-pau. É a coisa mais esquisita que já vi - um feixezinho de gravetos amarrados no meio. Não acreditei que estivesse vivo até que o vi se mover. Mesmo assim ele parecia mais um brinquedo mecânico do que uma criatura viva. Mas a pobre menina não conseguia fixar sua atenção. Seu coração estava muito perturbado e ela queria falar sobre isso. Ela disse: "Inseto pode saber sobre menina levada? Inseto está muito feliz?" Então, me abraçando pelo pescoço, disse: "Eu sou (vou ser) boa amanhã. Helen é (vai ser) boa todos dias". Eu disse: "Você vai pedir desculpas a Viney por têla arranhado e chutado?" Ela sorriu e respondeu: "Viney não (sabe) soletrar palavras". Eu disse: "Vou dizer à Viney que você pede desculpas. Você vai comigo procurar Viney?". Ela mostrou muito boa-vontade em ir e deixou Viney beijá-la, embora não retribuísse o carinho. [grifo nosso]

Envergonhar-se. Travar uma luta na própria mente. E não podemos deixar de dar crédito a essa professora que enxergou o erro e buscou de maneira até teatral, passar valores simples: respeitar o próximo e não agredir as pessoas. Não houve uma imposição de força, um "não pode" porque a regra diz isso ou aquilo. Não houve um castigo. Anne Sullivan ofereceu tempo para Helen Keller ficar consigo mesma e pensar. Tempo e pensamento.

Em “Educação após Auschwitz", Adorno (1995, p.125) chama a atenção para a necessidade de autonomia e poder. Poder para a reflexão, para a autodeterminação e para a nãoparticipação. E em “Educação - para quê?” (1995, p.141-142), Adorno apresenta resumidamente sua concepção inicial de educação para nos inspirar a pensar sobre a função da escola para além do espaço escolar:

Evidentemente não a assim chamada modelagem de pessoas, porque não temos o direito de modelar pessoas a partir do seu exterior; mas também não a mera transmissão de conhecimentos, cuja característica de coisa morta já foi mais do que destacada, mas a produção de uma consciência verdadeira. Isto seria inclusive de maior importância política; sua ideia, se é permitido dizer assim, é uma exigência política. Isto é: uma democracia com o dever de não apenas funcionar, mas operar conforme seu conceito, demanda pessoas emancipadas. Uma democracia efetiva só pode ser imaginada enquanto uma sociedade de quem é emancipado.

Talvez fique mais fácil de compreender esse poder, resgatando a discussão de Arendt (2004, p. 142-143) sobre as personalidades morais, que foram "os muito poucos, que no colapso moral da Alemanha nazista permaneceram completamente intactos e livres de toda culpa". Pessoas conscientes o suficiente para saberem "que os crimes permaneciam sendo crimes mesmo se legalizados pelo governo, e que era melhor não participar desses crimes em qualquer circunstância."

Pensamento, emancipação e democracia, para que haja reflexão e autodeterminação. Arendt (2004, p.160) fala na necessidade de pensar no passado, pois isso gera um movimento na dimensão da profundidade, na criação de raízes. Já Adorno (1996, s/p) aponta para o problema da formação cultural rasa, quando se pensa em ajustes de conteúdo, que levam à negação dos bens culturais, na medida em que negam o processo real da formação. Para este autor, o 
objetivo da formação é a autonomia. Esta ideia conversa com o que Arendt (2004, p. 156) escreve sobre a consciência, resgatando Sócrates, para quem todos os homens são seres pensantes, e para quem "pensamento é um diálogo travado pelo espírito consigo mesmo sem som”. Quando Adorno fala de autonomia e Arendt de pensamento, visualizamos Anne Sullivan dizendo para Helen Keller para não falar mais sobre a briga com Viney, mas pensar. A professora estimulou esse diálogo interno e não tinha pressa. O pensamento exige tempo. E ser capaz de dialogar consigo mesmo, não seria a conquista da autonomia?

Já Adorno (1995, p.151) acredita que o que caracteriza a consciência é "o pensar em relação à realidade, ao conteúdo", mas não apenas em termos de conhecimentos acadêmicos. Para Adorno, "a educação para a experiência é idêntica à educação para a emancipação" 48 .

Neste ponto, vemos possibilidades importantes a serem resgatadas no desenvolvimento que se deseja dar a este capítulo, que buscará, ainda, trazer reflexões sobre a educação a partir do conceito de crise de Arendt.

Quando ao menos uma pessoa para e pensa sobre o preconceito presente nas antigas “designações”, há uma crise, e talvez não seja coincidência que a crise na educação tenha emergido com mais força desse contexto reflexivo, quando as pessoas já discutiam esses assuntos em espaços públicos, quando fachadas vinham sendo dilaceradas e preconceitos, obliterados, em uma exata reprodução das palavras de Arendt (2006, p.223):

É a oportunidade, proporcionada pelo próprio fato da crise - que dilacera fachadas e oblitera preconceitos -, de explorar e investigar a essência da questão em tudo aquilo que foi posto a nu, e a essência da educação é a natalidade, o fato de que seres nascem para o mundo. $\mathrm{O}$ desaparecimento de preconceitos significa simplesmente que perdemos as respostas em que nos apoiávamos de ordinário sem querer perceber que originariamente elas constituíam respostas a questões. Uma crise nos obriga a voltar às questões mesmas e exige respostas novas ou velhas, mas de qualquer modo julgamentos diretos. Uma crise só se torna um desastre quando respondemos a ela com juízos pré-formados, isto é, com preconceitos. Uma atitude dessas não apenas aguça a crise como nos priva da experiência da realidade e da oportunidade por ela proporcionada à reflexão.

Essa crise vem exigindo a exploração e a investigação da essência de todas as questões, porque as antigas respostas perderam sua função. É a crise que nos faz pensar sobre como nomear, porque os velhos conceitos já não mais satisfazem; não têm mais validade.

Entretanto, faz-se necessário compreender que a educação inclusiva não é o ponto de partida dessas transformações, e sim um ponto a meio caminho da reflexão crítica ansiada por Adorno (1996, s/p). Sem pensamento crítico, não teria sido possível uma ação, a elaboração de

\footnotetext{
48 Aqui, deixamos este recorte simplificado que mereceria um desenvolvimento muito mais profundo. Seria necessário todo um estudo para que houvesse um resgate do sentido hegeliano de consciência e para desenvolvermos uma discussão sobre esse conceito em Adorno. Deixamos, pois, essa possibilidade para estudos futuros.
} 
uma Política de Estado propondo a inclusão. Esta se tornou possível devido às condições herdadas. A uma Constituição que a legitima.

E como já foi exemplificado, as novas respostas à crise transparece na substituição de termos como mongoloide por pessoas com síndrome de Down; de surdo-mudo ou mudinho, por Surdo, e mesmo as classificações da área de saúde passaram por transformações.

A apropriação de palavras e conceitos, do desenvolvimento dos mesmo para a formação da consciência, é importante porque a maneira de nomear, qualificar e descrever podem retratar mudanças concretas na forma de objetivar as relações. Mas nada é tão simples. Vivemos em um tempo de semiformação, onde a nova maneira de nomear, qualificar e descrever também podem ser mera conformidade. Um soletrar sem sentido. E o inverso também precisa ser considerado: vivemos em um tempo de semiformação que, ele mesmo, possibilita a alteração do que nos é apresentado, doutrinariamente, como inalterável, e fortalece a existência daqueles que não aceitam a dominação, na medida em que se apresenta como objeto passível de questionamento. Semiformação é barbárie: agressividade primitiva, ódio primitivo, impulso de destruição. E por isso Adorno (1995, p.155) aposta na urgente necessidade de desbarbarizar, para evitarmos que "toda esta civilização venha a explodir".

De forma similar, a alteração real, e não apenas nominal, da educação especial de um modelo segregacionista para uma perspectiva inclusiva, traz em si aspectos dialéticos que merecem atenção e cuidado. Aqui, parece-nos necessário resgatar um trecho de Marx (1956, p. 17) para caminharmos em nossa discussão sobre a educação democrática brasileira, e sobre a educação especial como parte dela:

Os homens fazem sua própria história, mas não a fazem como querem; não a fazem
sob circunstâncias de sua escolha e sim sob aquelas com que se defrontam direta-
mente, legadas e transmitidas pelo passado. A tradição de todas as gerações mortas
oprime como um pesadelo o cérebro dos vivos. E justamente quando parecem empe-
nhados em revolucionar-se a si e às coisas, em criar algo que jamais existiu, precisa-
mente nesses períodos de crise revolucionária, os homens conjuram ansiosamente em
seu auxílio os espíritos do passado, tomando-lhes emprestado os nomes, os gritos de
guerra e as roupagens, a fim de apresentar a nova cena da história do mundo nesse
disfarce tradicional e nessa linguagem emprestada.

Portanto, cabe mantermos a dúvida: na cidade de São Paulo, a educação inclusiva é revolucionária ou é apenas um desastre? Ela resgata os "espíritos do passado" e responde com juízos pré-formados? Manter a dúvida é importante para tomarmos cuidado com exemplos como o da educação democrática alicerçada na "meritocracia", que apenas reproduz a mesma lógica dos antigos sistemas oligárquicos e justifica a permanência da diferença, tendo por base uma nova retórica mascarada na ideia do "talento" (Arendt, 2011, p.228-229). Mesmo Adorno 
(1995, p.170) fala sobre a necessidade de "superar, por meio do esclarecimento, o falso conceito de talento". Reservadas as diferenças entre os Estados Unidos de meados do século XX - cenário estudado por Arendt - e a São Paulo das primeiras décadas do século XXI, encontramos aspectos que devem ser considerados quando se pensa sobre a universalização do ensino. Até que ponto ela é discurso? E onde ela é real?

E se Arendt nos alerta sobre os riscos dos juízos pré-formados, ao mesmo tempo, defende que a educação precisa ser conservadora. A complexidade está no equilíbrio entre a transformação e a conservação do mundo, e o cuidado para se evitar o mero restauro: quando a aparência de algo novo resgata, com tintas novas, a mesma imagem do passado. Ou ainda, quando se propõe uma revolução na arte, mas com os mesmos materiais: tela e tinta.

E em que sentido a educação precisa ser conservadora para Arendt (2011, p.243)?

Exatamente em benefício daquilo que é novo e revolucionário em cada criança é que a educação precisa ser conservadora; ela deve preservar essa novidade e introduzi-la como algo novo em um mundo velho, que, por mais revolucionário que possa ser em suas ações, é sempre, do ponto de vista da geração seguinte, obsoleto e rente à destruição.

E sua colocação nos faz pensar sobre a educação especial na perspectiva inclusiva. Existe uma proposta nova além da "tela e tinta"? Ela significa seguir um percurso novo, liberto dos modelos ideais impostos a todas as pessoas? Algo como as capas de enciclopédia ou os alguidares pintados por Dalton Paula? Ou seria isso uma distorção do foco, já que a educação, como pensada por Adorno, está associada diretamente à emancipação? Neste caso, a educação inclusiva não deveria tirar o foco da "inclusão" para que se possa voltar para a educação?

Segundo Adorno (1996), a educação não deve ter como referência uma formação cultural que seja mera semiformação socializada. A escola não precisa ser apenas um espaço físico a ser compartilhado, onde muita informação é transmitida e pouca reflexão é provocada. E é na aposta das possibilidades da educação que pretendemos nos aprofundar nas obras de Adorno e Arendt: produção de uma consciência verdadeira; formação de personalidades morais; a crise como oportunidade. Esses conceitos serão mantidos como referência para nortear nossa análise e para o desenvolvimento deste capítulo teórico, que buscará dialogar com os dados empíricos coletados por meio de entrevistas para, a partir desses modelos teóricos, refletir sobre a concepção de educação que prevalece nas escolas estudadas.

Sendo assim, deixamos para o aprofundamento teórico do quarto capítulo, sempre com foco na questão da inclusão de alunos com surdocegueira, as seguintes questões: qual o papel da escola em uma sociedade que se identifica como democrática? Como o conceito de inclusão 
dialoga com o modelo educacional bilíngue para Surdos e como esse cenário tem ou não relevância quando se pensa nos alunos com surdocegueira? E se estamos falando em inclusão, qual a formação necessária para "preparar” os educadores? 


\section{O MÉTODO}

\begin{abstract}
Mover-se é viver, dizer-se é sobreviver. Não há nada de real na vida que o não seja porque se descreveu bem. Os críticos da casa pequena soem apontar que tal poema, longamente ritmado, não quer, afinal, dizer senão que o dia está bom. Mas dizer que o dia está bom é difícil, e o dia bom, ele mesmo, passa. Temos pois que conservar o dia bom em uma memória florida e prolixa, e assim constelar de novas flores ou de novos astros os campos ou os céus da exterioridade vazia e passageira.
\end{abstract}

(Fernando Pessoa, O livro do desassossego)

A pesquisa que aqui se apresenta diz sobre presenças, sobre formas de estar e agir, portanto, sobre formas de mover-se... e "mover-se é viver". Trabalhamos com entrevistas orais de profissionais que atuaram ou atuam na RME de São Paulo, mais especificamente, nas EMEBS, a fim de "conservar o dia bom".

Em um contexto que valoriza a educação especial na perspectiva inclusiva, focamos nossa pesquisa em relatos sobre a chegada de alunos com surdocegueira nessas unidades. Sim, um "dia bom", independentemente dos conflitos enfrentados. Afinal de contas, a perfeição dos dias bons está na complexidade dos acontecimentos, e nos movimentos das pessoas envolvidas em busca de resoluções para as questões que surgem.

\subsection{A ABORDAGEM QUALITATIVA}

No presente estudo, fez-se uma opção pela abordagem qualitativa, na medida em que levou em consideração o contexto estudado, buscando o "significativo em sua singularidade", como afirmam Minayo e Sanches (1993, p.244).

As fontes primárias escolhidas para esta pesquisa foram as histórias de vida de profissionais da RME, todas educadoras. Essas histórias foram coletadas por meio de entrevistas orais semiestruturadas. Paralelamente, foram levantados materiais secundários. Tratam-se de documentos oficiais públicos, tais como publicações do Diário Oficial do Município de São Paulo, e os artigos e notícias das páginas virtuais da Secretaria Municipal de Educação ${ }^{49}$. Estes foram utilizados para a reunião de informações que permitiram o estabelecimento de diálogos com as narrativas ou, em alguns casos, serviram apenas como material ilustrativo e informativo sobre determinados temas - jamais sendo uma "prova" ou "contestação" a qualquer uma das falas. Quanto aos referenciais teóricos, as obras que compõem, com os excertos das entrevistas, a

\footnotetext{
${ }^{49}$ O Diário Oficial do Município de São Paulo tem suas edições disponíveis no site: <http://www.docidadesp.imprensaoficial.com.br/BuscaAvancada.aspx $>$. Já o endereço da Secretaria Municipal de Educação pode ser acessado em <http://portal.sme.prefeitura.sp.gov.br/Main/Page/PortalSMESP/home〉.
} 
base para as reflexões mais amplas sobre a educação e a perspectiva inclusiva, encontram-se: em Adorno, Educação e Emancipação, Teoria da Semicultura; em Adorno e Horkheimer, Dialética do Esclarecimento; em Arendt, Entre o Passado e o Futuro, A Condição Humana e Responsabilidade e Julgamento. As categorias centrais que irão nortear as discussões e reflexões são Educação e Normalidade, para compreendermos o que as educadoras que colaboraram com a presente pesquisa compreendem como sendo Educação e como a ideia de Normalidade comparece mesmo em uma unidade que teve um passado como escola especial e está constituindo e fortalecendo sua identidade como escola bilíngue.

No que diz respeito à abordagem qualitativa, Schmidt (2008) nos inspira a parar para pensar sobre a pesquisa participante e a formação ética do pesquisador na área da saúde. Lendo seu artigo e trazendo-o para este estudo, as considerações poderiam ser ampliadas, e o título não se restringe apenas para a área da saúde. Poderíamos propor, com este resgate: “A pesquisa e a formação ética do pesquisador”. Essa ampliação da discussão ética, para além da área da saúde e do universo dos instrumentos burocráticos para uma reflexão moral, é atual e mostrase necessária. Schmidt fomenta a prática científica consciente, em todas e a cada nova etapa da pesquisa, e defende: a "ética é morada, modo de habitar o mundo e lugar de atualização de valores e atitudes" (SCHMIDT, 2008, p.392). A cada contato, a cada encontro, e a cada entrevista, esperamos seguir suas orientações, aqui reproduzidas integralmente:

1. Busca de interlocução e diálogo no trabalho de campo, visando compreender o sentido e os significados da experiência de outros próximos ou distantes.

2. Distribuição democrática de lugares de escuta, fala e decisão entre pesquisador e colaboradores ou interlocutores.

3. Disposição para negociar e refazer os contratos ou pactos de trabalho compartilhado entre pesquisador e colaborador sempre que necessário.

4. Empenho no esclarecimento, fidelidade, respeito e solidariedade às formas de viver desenhadas pelos colaboradores e cuidado em sua transcrição em texto.

5. Embora os efeitos políticos e ideológicos da divulgação e recepção de uma pesquisa não possam ser planejados ou controlados pelo pesquisador, a antevisão e a ponderação destes eventuais efeitos podem fazer parte do horizonte de preocupações presentes no momento da escrita, direcionando escolhas sobre o quê, como e para quem escrever.

6. Abertura para sempre que possível e como atitude metódica da pesquisa de campo realizar revisão conjunta com os colaboradores de transcrições de relatos orais e de observações, bem como de textos interpretativos.

7. Atribuição de créditos, por ocasião de publicações, aos colaboradores, bem como uso de nomes próprios de narradores e interlocutores quando eles assim desejarem e omissão sigilosa de nomes e outras informações que possam identifica-los quando eles assim preferirem ou precisarem.

8. Discussão de formas de divulgação de resultados de pesquisa que possam interessar aos colaboradores. (SCHMIDT, 2008, p.397)

A presente pesquisa não pôde contemplar plenamente os dois últimos itens - 7 e 8 devido ao TCLE, que especifica o sigilo como característica prévia. Entretanto, a postura ética, 
dialógica, alicerçada em valores como respeito e ponderação, foi perseguida a todo momento. Nesse sentido, o uso das histórias de vida como fontes para uma reflexão teórica pautada na abordagem qualitativa, foi perpassada por reflexões, que por sua vez procuraram ir ao encontro das normas e modelos de pesquisa estabelecidos pela própria área de produção de conhecimento. Os pesquisadores que utilizam a história oral reforçam essa discussão. Basta resgatarmos os trabalhos de Portelli (1997) e Meihy (2000; 2015). Portanto, os protocolos, ou melhor, as atitudes éticas que vêm sendo construídos há décadas, alicerçaram esta pesquisa.

\subsection{A ESCOLHA DAS HISTÓRIAS DE VIDA}

A escolha pelo registro das histórias de vida justifica-se pela ênfase na subjetividade, onde buscaremos a força desses relatos, como apontado por Meihy (2000, p.61). Tal metodologia condiz com nossas expectativas, pois não se trata apenas de reunir, de forma temática, respostas para questões pré-estabelecidas - apesar de deixarmos claro, a todo momento, qual o tema de nossa pesquisa: a inclusão de alunos com surdocegueira nas EMEBS da RME de São Paulo.

Nesse sentido, seguimos as orientações de Meihy (2000, p.62), para quem o colaborador tem "liberdade para dissertar o mais livremente possível sobre sua experiência pessoal" e foi dado "espaço para que sua história seja [fosse] encadeada segundo sua vontade." Buscamos interferir o mínimo possível, deixando nossos entrevistados definirem os aspectos considerados relevantes em seu percurso, a partir do tema norteador desta pesquisa.

A opção pelas histórias de vida justifica-se, ainda, pela nossa expectativa de encontrar nas narrativas de experiências passadas, o substrato para as ações desses profissionais em sua prática. Dessa forma, esperamos traçar suas trajetórias individuais, desde a infância até a chegada dos alunos com surdocegueira nas EMEBS, verificando quando e onde compareceram dados relacionados à história da educação de pessoas com deficiência na cidade de São Paulo, tendo em vista a perspectiva inclusiva que vem se consolidando, principalmente nesta última década. 
Apesar da liberdade que foi dada no momento da coleta, e mesmo tendo como base metodológica o trabalho de Meihy (2000), entendemos que na individualidade pode ser resgatado o social. É o que Ferrarotti (1988 apud BUENO, 2002, p.19) ${ }^{50}$ defende: "podemos conhecer o social a partir da especificidade irredutível de uma práxis individual”.

Portanto, reunimos quatro narrativas individuais que compõem um cenário específico e o moldam, sendo, ao mesmo tempo, moldadas por esse contexto. Conforme as palavras de Clandinin e Connely (GOODSON, 2000, p.68) "tentaram compreender o conhecimento prático pessoal dos professores", apesar de atentarmos para essa individualidade, levamos em consideração o alerta de Goodson sobre o fato de muitos desses estudos trazerem o professor como a própria prática, e não como uma pessoa que trabalha como professor ${ }^{51}$.

Ainda sobre esse aspecto, Nóvoa (2000, p.17) reproduz uma questão de Laborit que enxerga essa confusão e propõe uma reflexão: "Será que a educação do educador não se deve fazer mais pelo conhecimento de si próprio do que pelo conhecimento da disciplina que ensina?"

Elegemos as histórias de vida em uma tentativa de valorizar a pessoa, antes do profissional; a unicidade, antes da categoria; tendo ciência de que essas unidades compõem um corpo social mais amplo, que influencia essa prática individual e esta é, da mesma forma, influenciada por esse contexto.

\subsection{SOBRE A ORALIDADE EM TRAJETÓRIAS VISUAL-MOTORAS}

Cabe uma reflexão sobre a opção metodológica em áudio. Sendo uma pesquisa que tem como tema a surdocegueira, por que não vídeos? A opção pelas histórias de vida se deu visando retomar elementos da subjetividade de profissionais ouvintes. Sabíamos que seríamos nós, pesquisadores, que estaríamos à frente dos participantes que aceitassem contribuir com suas narrativas de forma voluntária. Como nos lembra Bueno (2002, p.20) “a situação interacional vivenciada, isto é, o modo mediante o qual a narrativa ou as narrativas foram produzidas, não pode ser ignorado no processo de análise". E acreditávamos que seria uma situação interacional que traria experiências auditivas anteriores ao bilinguismo, estabelecida entre duas pessoas

\footnotetext{
${ }^{50}$ FERRAROTTI, F. Sobre a autonomia do método biográfico. In: NÓVOA, A.; FINGER, M. (orgs.) O métodos (auto)biográfico e a formação. Lisboa: Ministério da Saúde. Depart. de Recursos Humanos da Saúde/Centro de Formação e Aperfeiçoamento Profissional, 1988, p.17-34.

${ }^{51}$ Mas vale uma ressalva: essa confusão não é regra. Nóvoa (2000, p.21-23) lista e distingue diferentes objetivos e enfoques, com respectivos teóricos. Estudos com objetivos teóricos, práticos e emancipatórios, relacionados com a investigação e/ou formação da pessoa (do professor) por meio das práticas, da profissão ou da pessoa.
} 
adultas ouvintes que têm na modalidade oral da língua portuguesa, sua primeira língua, e também sua língua natural ${ }^{52}$. Contudo, a entrevista com profissionais de uma escola bilíngue que tem na Libras sua primeira língua, provocou reflexões sobre esse aspecto que serão retomadas nas considerações finais. Por ora, importa registrarmos que algumas colaboradoras comunicavam algumas palavras ou expressavam pequenos detalhes em Libras, e uma delas utilizava-se muito das expressões faciais - possivelmente por ser uma característica própria, mas que o ambiente bilíngue fortalece.

\subsection{AS ETAPAS DA PESQUISA}

A pesquisa teve início com o levantamento de dados quantitativos sobre alunos com surdocegueira na RME, por meio de ofício enviado ao então Secretário Municipal de Educação. Paralelamente, foi feito um levantamento dos estudos acadêmicos - teses, dissertações e artigos - sobre surdocegueira no Brasil. As bases de dados consultadas foram: Banco de Teses e Dissertações USP; Banco de Teses e Dissertações Mackenzie; Biblioteca Digital Brasileira de Teses e Dissertações; Biblioteca Digital da UNICAMP; BIREME - Biblioteca Virtual em Saúde; Banco de Teses CAPES; SCIELO.

A partir dos dados recebidos da Secretaria Municipal de Educação e com as informações constantes nas dissertações e teses localizadas, procurou-se criar uma rede de contatos para identificar profissionais que poderiam ser convidados para a realização das entrevistas, tendo como base os critérios estabelecidos no projeto de pesquisa.

Apesar de iniciarmos contatos com as equipes gestoras das EMEBS ${ }^{53}$, deixamos essa opção para seguirmos por um caminho via redes sociais, para que a identidade de qualquer pessoa que contribuísse com a pesquisa pudesse ser preservada, inclusive dentro de cada unidade. Isto é, mesmo as equipes gestoras das EMEBS têm conhecimento ou sabem se estão ou não participando da pesquisa. Tal decisão fez com que todos os contatos e entrevistas fossem

\footnotetext{
52 Quando utilizamos "língua natural” neste trabalho, fazemos referência a estudos relacionados à Surdez, que afirmam ser a língua de sinais a língua natural dos Surdos. Para os ouvintes, geralmente a língua natural é também a língua materna e a primeira língua aprendida. No caso de Surdos, filhos de pais ouvintes, a sua língua natural difere da língua materna, o que pode ter uma série de implicações. Um estudo que introduz a questão é o texto de Lacerda (2000).

${ }^{53}$ No caso, seguimos a Circular Normativa no 01/12 - SME-G "Dirigida aos Diretores Regionais de Educação, Supervisores Escolares, Gestores dos Centros Unificados-CEUs e Diretores de Escolas das Unidades Educacionais da Rede Municipal de Ensino", com instruções relacionadas aos procedimentos comuns estabelecidos frente às solicitações para a realização de pesquisas acadêmicas. Chegamos a entregar toda a documentação exigida, porém, tendo em vista a demora na formalização de respostas, foi necessário tomar decisões sobre novos processos que se mostrassem livres de uma resposta formal das unidades.
} 
realizados fora do espaço escolar, tendo ocorrido ou nas residências das colaboradoras, ou na residência da entrevistadora, ou em espaços públicos, conforme opção de cada participante.

Após o contato e o aceite, foi realizada a entrevista, transcrição e análise. Não foi estabelecido um roteiro fixo, nem questionários, seguindo as referências da História Oral, conforme informado anteriormente. As entrevistas foram guiadas por perguntas abertas, ficando garantida total liberdade para que os voluntários respondessem ou não às questões, assim como para abordarem outros assuntos, ou até mesmo, manterem silêncio.

Faça-se a ressalva de que, em nenhum momento as unidades educacionais foram identificadas, visando a garantia do sigilo e do anonimato de todos os voluntários que participaram da pesquisa segundo procedimento de pesquisa utilizado pela instituição e aprovado pelo CEP. A única identificação será "EMEBS da Rede Municipal de Ensino”. Da mesma forma, algumas datas foram omitidas, sendo mantidas apenas aquelas que servem como ponto de referência temporal, a fim de garantir a compreensão do contexto. A identificação de algumas instituições citadas pelas pessoas entrevistadas também foi evitada, ficando no texto uma descrição geral. A título de exemplo, o nome das escolas onde estudaram somente foram descritas como escola particular ou escola pública, posto que esta delimitação parecia ao mesmo tempo genérica e relevante a este estudo, mais que outras que indicassem outras características como localidade ou antiguidade. Todos os nomes, tanto dos voluntários como o de alunos ou outras pessoas citadas nas entrevistas, foram alterados por nomes fictícios.

\subsubsection{A escolha das colaboradoras}

A escolha das colaboradoras que participaram da pesquisa teve como norte a soma das seguintes características: profissionais - professores e/ou gestores - da Rede Municipal de Ensino (RME) da cidade de São Paulo, que:

- atuam ou atuaram nas atuais EMEBS, portanto sujeitos adultos;

- saibam Libras;

- tenham atuado direta ou indiretamente na inclusão de alunos com surdocegueira em alguma EMEBS;

- tenham interesse em contribuir, voluntariamente, com o presente estudo.

Interessa esclarecermos o fato de, inicialmente, contarmos com outras três características que foram abandonadas como requisitos, mas permaneceram como aspectos importantes para a análise e discussão. A saber: 
- aprenderam outras formas de comunicação, voltadas especificamente a pessoas com surdocegueira;

- estejam próximos da aposentadoria ou que já se aposentaram, tendo um tempo de experiência mínimo de oito anos nessas unidades;

- tenham realizado formações específicas na área de surdocegueira - seja de forma independente ou por meio de ações da SME.

O requisito relacionado à aposentadoria foi descartado porque ele limitava a pesquisa a um perfil de profissionais, o que consideramos uma restrição à nossa análise, já que foi possível notar mudanças nas EMEBS, cujos protagonistas eram os "professores novos". Apesar de sabermos se tratar de uma análise-narrativa que não busca uma suposta universalidade, a potência de uma reunião mais diversificada de falas nos pareceu pertinente já que, ao considerarmos o funcionamento de uma unidade educacional como um todo, notamos a complexidade das equipes envolvidas.

A opção pelo abandono do primeiro e do último requisitos - sobre as formas de comunicação e formações específicas na área de surdocegueira - se deu porque, durante o exame de qualificação, foi apontada a possibilidade de uma melhor compreensão do contexto ao ouvir aqueles profissionais que não tivessem realizado formações específicas - subespecializações. Estes sujeitos poderiam, como adultos presentes a partir de um outro lugar, fornecer elementos diferenciados para a compreensão da dinâmica dessas unidades e de opções pessoais.

A partir da primeira entrevista piloto - definida por Meihy (2000, p.84) como ponto zero - foi realizada uma análise para o estabelecimento de prioridades ou de parâmetros para a escolha dos demais entrevistados e o estabelecimento da rede ${ }^{54}$. Isto ocorreu, também, porque ao deixarmos o espaço institucional, do contato direto com as equipes gestoras das unidades educacionais, e optarmos pelo espaço virtual das redes sociais, deparamo-nos com uma rede de indicações que ampliou a escolha dos demais colaboradoras.

A opção por esse procedimento teve em conta o fato de estarmos frente a uma colônia limitada. Conforme Meihy (2000, p.83), a colônia é estabelecida tendo como base histórias com "traços preponderantes que ligam a trajetória de pessoas". Identificamos essa colônia como sendo o de profissionais da RME de São Paulo - funcionários concursados e com uma carreira pública. No caso específico desta pesquisa, a rede, subdivisão dentro dessa colônia (MEIHY,

\footnotetext{
${ }^{54}$ Foi nesse momento, com a orientação dos participantes da banca de qualificação, que os critérios passaram a ser revistos.
} 
2000, p.84), é uma rede dispersa em diferentes partes da cidade, composta por apenas seis unidades educacionais - as EMEBS - em um universo muito mais amplo que é a RME. Com a formação da rede, após a realização dos contatos, todas as entrevistadas acabaram sendo pessoas da mesma unidade educacional. Isto também justifica a opção pelo não compartilhamento da identificação da mesma, a fim de assegurar o sigilo previsto no TCR.

Importa-nos lembrar que a própria pesquisadora participou dessa rede, com a qual teve contato direto durante o período de atuação como professora na RME de São Paulo. Nesse sentido, o surgimento desta pesquisa está diretamente relacionado com essa experiência e uma percepção de uma questão que surgiu de uma problemática vivida.

\begin{abstract}
Assim, os temas são selecionados a partir da formulação de uma problemática do presente. Isso garante à história um constante movimento, um processo dinâmico, que se afasta de conceitos cristalizados como verdade e neutralidade. A história oral, por sua vez, potencializa esse movimento, na medida em que o pesquisador passa a se relacionar com seres vivos que influenciam, emocionam e transformam o papel do pesquisador. (RIBEIRO, 2007, 194)
\end{abstract}

Portanto, apesar do estabelecimento de estratégias que visavam a neutralidade e distanciamento, devemos chamar a atenção para esse relacionamento real prévio com essas pessoas, alunos e educadores, que nos influenciaram, emocionaram e transformaram. Foi essa proximidade, também, que nos permitiu uma compreensão de vários sentidos e significados, inclusive em termos burocráticos, como inúmeras siglas e abreviaturas utilizadas nas entrevistas pelas colaboradoras. Esse lugar de ex-professora da RME, também facilitou o contato inicial, pois havia sempre alguém próximo que podia fazer a indicação ou nos apresentar, e fez com que o tempo anterior e posterior às entrevistas fosse muito mais longo, com conversas informais sobre a educação e sobre a RME como um todo.

Foram definidas quatro colaboradoras e as entrevistas foram realizadas entre os meses de outubro de 2015 e novembro de 2016. Sobre as colaboradoras, importa sublinharmos o fato de que são todas mulheres, duas da equipe gestora e duas professoras, todas da mesma EMEBS. Buscamos evitar essa restrição a uma única unidade, porém, as indicações convergiram para ela.

Da equipe gestora, uma era diretora, e a outra era coordenadora, ambas com conhecimentos de Libras, e que ocupavam esses cargos no momento da chegada daquele que se considerava ser "o primeiro aluno com surdocegueira". A primeira encontra-se, hoje, aposentada; a segunda solicitou remoção e está atualmente em uma EMEI.

Das professoras, foram entrevistadas uma de Ensino Fundamental I, que já tinha um percurso de mais de dez anos na unidade em questão quando da chegada desse aluno na escola, 
e que tinha fluência em Libras antes mesmo de seu ingresso na EMEBS. A outra professora, de Ensino Fundamental II, chegou nessa unidade educacional após o ingresso desse aluno com surdocegueira, mas acompanhou-o durante o ciclo II. As duas professoras continuam nessa mesma unidade.

Tabela I - Nome fictício adotado para cada colaboradora e respectivo cargo:

\begin{tabular}{|r|l|}
\hline SARA & Diretora \\
\hline LÍDIA & Coordenadora \\
\hline RUTE & Professora de Ensino Fundamental II \\
\hline ESTER & Professora de Ensino Fundamental I \\
\hline
\end{tabular}

\subsubsection{O contato inicial: explicitando os objetivos}

O contato inicial com os profissionais foi realizado individualmente por telefone, ou por mensagem de texto eletrônica via e-mail, WhatsApp ${ }^{55}$ ou Facebook Messenger ${ }^{56}$ visando garantir a manutenção do sigilo em todas as etapas da pesquisa. Nessa ocasião, foram explicitados os objetivos e, caso o(a) voluntário(a) demonstrasse interesse, uma cópia do projeto aprovado pelo CEP foi enviado para leitura e análise prévios ${ }^{57}$.

Autores como Meihy e Ribeiro (2011, p.193) chamam esse momento de pré-entrevista, definindo-o como o

momento no qual se apresenta, em linhas gerais, o projeto de pesquisa para os colaboradores, se elucida os procedimentos, a necessidade de utilização de equipamentos eletrônicos para o registro da entrevista e se agendam datas, horários e os locais onde elas serão gravadas.

\footnotetext{
55 Aplicativo gratuito para troca de mensagens (em texto, imagens, vídeo ou áudio) disponível para uso em aparelhos de telefonia móvel. Permite o envio de mensagens, inclusive para pessoas que não fazem parte dos contatos, ficando ao receptor a liberdade de abrir ou não a mensagem.

${ }^{56}$ Aplicativo gratuito do Facebook para troca de mensagens de texto. Também permite que sejam anexados imagens, arquivos ou links para páginas virtuais. Possibilita o contato, inclusive com pessoas que não fazem parte do "círculo de amigos", ficando ao receptor a decisão de ler e responder cada mensagem.

${ }^{57}$ Havendo interesse e solicitação por parte dos sujeitos convidados para participar da pesquisa, ficamos à disponibilidade para realizar encontros anteriores às entrevistas, para que eventuais dúvidas pudessem ser sanadas da melhor forma possível.
} 


\subsubsection{A participação voluntária}

Tendo em vista o caráter científico-acadêmico desta pesquisa, vinculada a uma instituição pública de ensino superior que não visa o lucro, e a ausência de financiamento, seja público ou privado, a participação na pesquisa e a cessão das entrevistas ocorreu de forma voluntária. Esta informação consta no TCLE e foi explicitada oralmente e por escrito desde o primeiro contato com cada participante.

\subsubsection{A realização das entrevistas}

Com o consentimento para a participação na pesquisa, o local para a realização das entrevistas foi definido em comum acordo, não sendo nas dependências das unidades educacionais.

Inicialmente e conforme o próprio TCLE, pensamos em dois encontros com cerca de uma hora e meia, mas cada participante apresentou um perfil diferenciado e seguimos a disponibilidade de cada pessoa. Isso fez com que acontecessem encontros de uma hora e meia até cinco horas de duração, incluindo uma conversa inicial, a montagem do equipamento de gravação, a realização da entrevista e a desmontagem. Cabe uma observação sobre a discrepância no cômputo total da extensão das gravações e sobre a mudança da metodologia.

Ao iniciarmos a pesquisa, pensávamos na necessidade de um primeiro encontro quando realizaríamos uma apresentação nossa para o voluntário ou a voluntária, explicitando os objetivos do projeto e para sanarmos qualquer dúvida. Entretanto, com o desenrolar dos contatos, como uma ex-profissional da RME e como uma pessoa que atuou nas instituições conveniadas à RME, pudemos notar que já havíamos encontrado todas as pessoas envolvidas na pesquisa. Mesmo não tendo proximidade e não sendo pessoalmente próximas, já no contato prévio informal, via redes sociais ou e-mail, foi possível notar uma disposição para a conversa e a ausência de qualquer receio, talvez pelo fato da pesquisadora identificar-se como antiga professora da rede, uma ex-colega. Isto permitiu a realização das entrevistas de forma mais direcionada sendo, em alguns momentos, muito mais rápida.

As duas colaboradoras iniciais que atuaram mais diretamente na inclusão do aluno com surdocegueira, contribuíram, cada uma, com cerca de duas horas de entrevista. A primeira, que fazia parte da equipe gestora e nos forneceu esclarecimentos inclusive sobre a legislação; e a segunda, que foi a professora que acompanhou esse primeiro aluno com surdocegueira por mais tempo. 
Tabela II - Tempo médio de gravação e de conversa com cada colaboradora, listada segundo a sequência de realização das entrevistas:

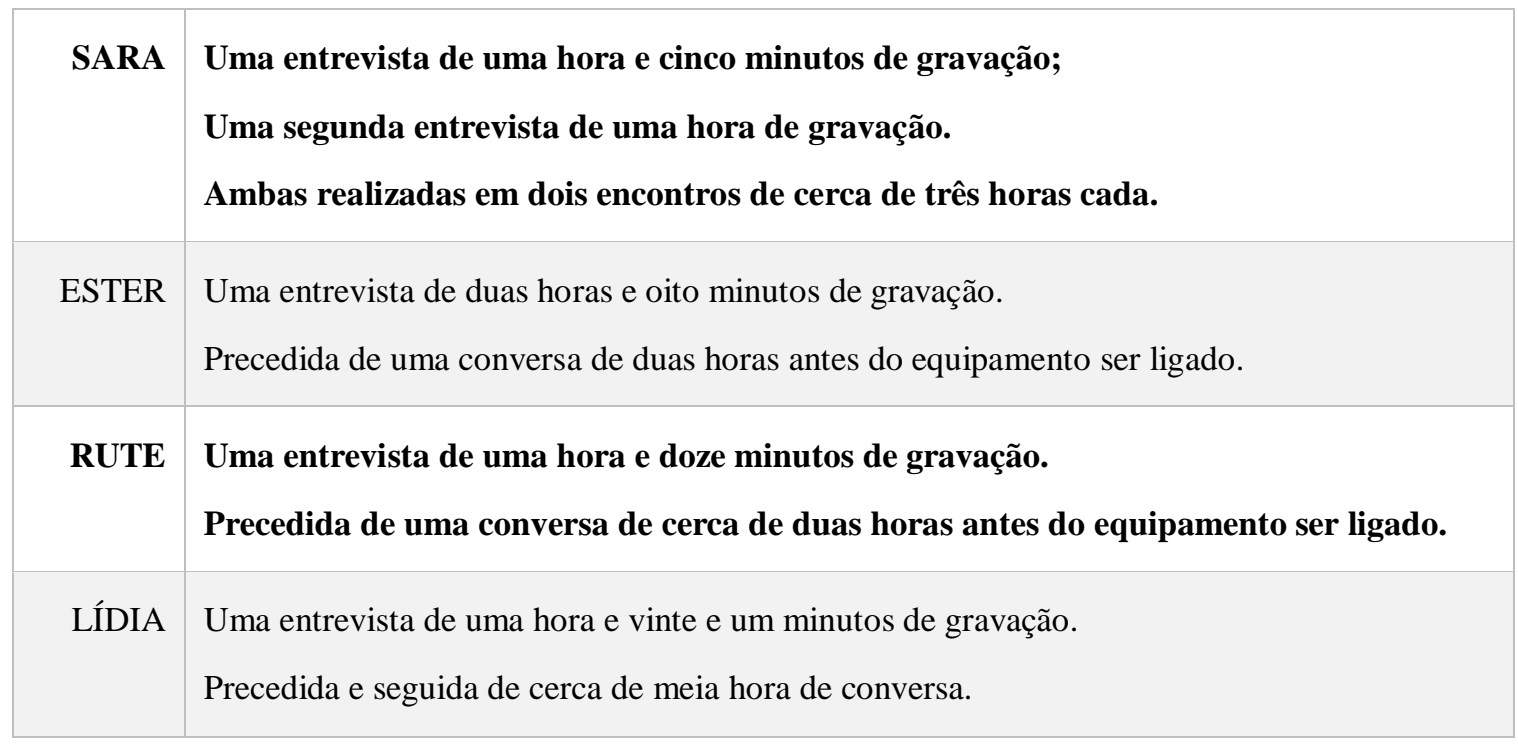

Relembrando, a história de vida, que tem como objetivo retomar a trajetória do entrevistado, requer um tempo mais longo. Entretanto, as entrevistas de história de vida podem não seguir divisões cronológicas que abarquem toda a vida, desde o nascimento. Foi o que houve nesta pesquisa: as conversas tiveram como norte acontecimentos e/ou lembranças da trajetória de vida de cada colaboradora, relacionados com a temática da formação - não apenas acadêmica, mas também ética, moral, religiosa, entre outros - e pautados pelo tema: a inclusão dos alunos com surdocegueira nas EMEBS. Foi dada ênfase, também, aos fatos ou episódios considerados relevantes nessas trajetórias para a definição da forma de atuação profissional. Assim como propõe Ribeiro (2007, p.214-215), tentamos evitar impor uma temporalidade alheia a elas, permitindo-nos lançar "questões mais pontuais, necessárias para o entendimento de uma ou outra passagem, ou resultantes da curiosidade motivada pela conversa. Assim, o que se apresentou no texto é o resultado de um diálogo" que, como essa autora nos lembra trazendo Bosi, não está livre de "uma divagação, uma descontração do espírito".

Ressalve-se que, apesar de alguns direcionamentos temáticos, cada uma das colaboradoras decidiu o que e como seria relatado. Se, por um lado, isso dificultou a análise conjunta das entrevistas, por outro, essas diferenças evidenciaram a pluralidade, que tanto nos é cara. 


\subsubsection{As devolutivas}

Após cada entrevista, a versão em áudio foi transcrita para que o texto pudesse ser enviado por e-mail para cada participante. Inicialmente, pensávamos em realizar a leitura em conjunto, em data, horário e local acordados previamente. Entretanto, o intenso ritmo que o período letivo escolar imprime sobre os profissionais da educação, mostrou-se como um obstáculo. Mais do que profissionais da educação, devemos lembrar que tratam-se de pais, mães, irmãos, irmãs, filhos, filhas, pessoas que além do trabalho devem ter garantidos tempos sociais, familiares, livres... e entretempos. Por isso, a opção pelo envio do texto por e-mail, para que cada um pudesse ler e fazer eventuais considerações, buscou a garantia do conforto de cada participante da pesquisa. Quando possível, foi realizado um encontro pessoal para a realização da devolutiva e essa possibilidade foi explicitada a todas as voluntárias, cabendo a elas decidir pelo encontro pessoal ou não.

Por fim, importa sublinharmos que, nesta pesquisa, não foram realizadas as etapas da textualização e da transcriação propostas por Bom Meihy (2000, p.90-91).

\subsection{PROCEDIMENTOS DE ANÁLISE}

A partir das entrevistas transcritas, demos início a uma leitura atenta de todo o material, tendo como pano de fundo as categorias de análise trazidas de nosso referencial teórico. Foi redigida, então, uma breve apresentação de cada participante, em forma de texto em terceira pessoa, com informações mais objetivas sobre o percurso acadêmico e profissional. Essa apresentação buscou destacar trechos das entrevistas que mantivessem algumas expressões e "entonações" peculiares a cada participante, a fim de preservar "o acervo fraseológico e a caracterização vocabular de quem contou a história"(MEIHY, 2000, p.89).

Não foi reproduzida e não será disponibilizada nenhuma entrevista em sua totalidade. Optamos pelo uso híbrido dessas entrevistas (MEIHY, 2000, p.92). Isto é, como já apresentado anteriormente, com outras documentações como as publicações do Diário Oficial do Município de São Paulo e materiais publicados nas páginas virtuais da Secretaria Municipal de Educação, mas, principalmente, em diálogo com o referencial teórico listado anteriormente. 


\subsection{PROCEDIMENTOS ÉTICOS}

Tendo em vista a participação de seres humanos, o projeto do presente estudo foi submetido ao Comitê de Ética em Pesquisa com Seres Humanos do Instituto de Psicologia da Universidade de São Paulo e, conforme orientações, a pesquisa de campo somente foi iniciada após receber aprovação do mesmo.

Explicitamos a todas as participantes a plena liberdade de aceitar ou recusar participar da pesquisa, ficando garantidos em ambos os casos - tanto no do aceite como no da recusa -, a privacidade e a confidencialidade da identidade dos convidados e/ou das convidadas. Da mesma forma, ficou clara a possibilidade de se interromper as entrevistas e a participação na pesquisa, a qualquer momento, sem qualquer prejuízo ao voluntário e/ou à voluntária.

No texto final, foram utilizados nomes fictícios e apenas cada participante teve acesso à identificação do nome fictício que lhe corresponde ${ }^{58}$. O Termo de Consentimento Livre e Esclarecido (TCLE) ${ }^{59}$ especifica os objetivos, informa sobre a garantia do sigilo e as possibilidades de interrupção ou retirada do consentimento.

A análise e uso dos dados partiu da autorização, por meio de assinatura do TCLE, e pelo envio digital do texto por e-mail. Foi ofertada a todas as colaboradoras a possibilidade de um encontro pessoal final para qualquer esclarecimento que pudesse vir a ser necessário. Apesar das gravações ficarem guardadas por um período de dois anos ${ }^{60}$, conforme acordado no TCLE, justificamos a opção pelo uso da versão transcrita por um lado, pelo interesse na seleção de partes da entrevista; por outro, porque a transcrição permitiu uma avaliação contextual para evitarmos seleções imprecisas.

Após o uso da entrevista, pela pesquisadora, a partir da primeira transcrição, trechos do texto da dissertação foram enviados para cada participante, possibilitando eventuais intervenções ou correções. Essa postura tinha como interesse evitar que, expressões retiradas de um contexto oral, pudessem gerar interpretações equivocadas.

\footnotetext{
${ }^{58}$ Foi oferecida a cada participante a possibilidade de escolher o nome fictício. Para mais reflexões sobre a questão do sigilo, ver também MEIHY (2015).

${ }^{59}$ Ver Apêndice 2.

${ }^{60}$ As gravações serão guardadas por um período de dois anos e estarão em posse da pesquisadora, com livre acesso por parte do voluntário. Após esse período, serão destruídas.
} 


\section{UM MONUMENTO INVISÍVEL}

The question of education is a more recent one, where I began looking at notions of monuments, and how they occupy space, more specifically in South Africa. It then struck me that the heaviest colonial monument, and one that we do not necessarily "see" or identify, but rather experience, is the structure of Education. That is my relationship to Institutionalized Education. It's looking beyond the physical structures, and identifying how it performs itself in various spaces.

(Donna Kukama, 2016 ${ }^{61}$ )

Um elemento onipresente na nossa sociedade, compreendido como um dever inquestionável em uma democracia que preza o bem comum, é a educação. Mas de que educação estamos falando? Quais as implicações relacionadas a ela?

As palavras de Donna Kukama nos fazem pensar a educação como um monumento invisível que experienciamos mesmo fora das estruturas físicas, por não ser algo material - apesar de estar materializado e objetivado em prédios, documentos, livros, entre outros. Ela evidencia, a partir de seu olhar sobre essa instituição na África do Sul, o potencial de violência presente na mesma.

Se por um lado a educação acolhe e protege as pessoas "normais" - e aqui emprestamos a definição de Goffman (2008, p.14) que em seu trabalho assim identifica "nós e os que não se afastam negativamente das expectativas particulares em questão" - essa mesma instituição pode apresentar aspectos negativos, ao excluir a diferença. E isso engloba situações em que ela age movida por uma suposta benevolência, mas esta se restringe ao compartilhamento físico de um espaço comum, sem a apropriação efetiva, por todos, desse espaço. Porém, quando segue efetivamente os princípios democráticos, a educação tende a um caminho diverso.

Estudar o ambiente educacional público paulistano exige atenção porque, se há aspectos que podem ser negativos, há também algo que não podemos deixar de perceber: um potencial de efetiva transformação da sociedade. Nesse sentido, quando a escola deixa de ser um espaço de mera reprodução - e aqui pensamos no trabalho de Bourdieu e Passeron (2010) sobre o sistema de ensino como reprodutor e mantenedor da estrutura das relações entre as classes -, ela pode auxiliar na desconstrução dos preconceitos e das respostas antigas para as quais Arendt

\footnotetext{
61 Tradução livre: “A questão da educação é uma que é mais recente, onde eu comecei a olhar para noções de monumentos, e como eles ocupam o espaço, mais especificamente na África do Sul. E então me impressionou o fato de que o monumento colonial mais pesado, e um que nós não precisamos necessariamente "ver" ou identificar, mas ao invés disso experienciar, é a estrutura da Educação. Essa é a minha relação com a Educação Institucionalizada. É o olhar para além das estruturas físicas, e identificar como elas se realizam em vários espaços." Resposta enviada pela artista, em e-mail para a equipe de mediadores, durante o período de formação da $32^{a}$ Bienal de São Paulo, no ano de 2016. Foi solicitada autorização para uso do trecho citado.
} 
(2011, p.223) chama nossa atenção. É com esse cuidado que buscamos estabelecer a discussão teórica a partir dos excertos das entrevistas.

Vale lembrar, ainda, que já desenvolvemos um capítulo intitulado "Educação em tempos de semiformação", onde pontuamos as ideias de Adorno e Arendt que deram base para as nossas reflexões. Nesta parte do trabalho buscaremos, em primeiro lugar, apresentar as colaboradoras para, então, aprofundarmos a discussão tendo dois eixos-questões principais:

1. Qual a concepção de educação dessas profissionais?

2. Como a ideia de "normalidade" comparece nas EMEBS?

E quando perguntamos sobre a concepção de educação, lembramos de Adorno, que a vincula à emancipação e à consciência, tendo a não violência como requisito. As discussões buscaram atentar para a relação violência - não-violência, para além da obviedade. Isto porque, apesar de considerar a existência de situações extremas em que "sem violência não é possível", Adorno reforça que

é preciso haver clareza de que até hoje ainda não despertou nas pessoas a vergonha acerca da rudeza existente no princípio da cultura. E que somente quando formos exitosos no despertar desta vergonha, de maneira que qualquer pessoa se torne incapaz de tolerar brutalidades dos outros, só então será possível falar do resto. (ADORNO, 1995, p.165-166)

Devemos reler com atenção: "de maneira que qualquer pessoa se torne incapaz de tolerar brutalidades dos outros". Tornar-se incapaz de tolerar brutalidades, sejam elas verbais, sejam elas físicas, sejam elas intangíveis - afinal de contas, ignorar o outro ou não reconhecer o outro, também é uma forma de violência, muitas vezes imperceptível. E é necessário ter clareza que uma instituição escolar que perpetua qualquer forma de desigualdade, é brutal, como nos lembra Becker em sua conversa com Adorno (ADORNO, 1995, p.170) em uma discussão que parte do argumento prévio da "falência da cultura" (ADORNO, 1995, p.164); uma cultura que nada fez além de dividir os homens.

E qual a contribuição de Arendt? Essa autora entende a educação como uma postura frente ao mundo, e o educador como um representante desse mundo. Mas não se trata de um representante inerte. $\mathrm{O}$ educador é um representante que assume a responsabilidade por esse mundo. Uma responsabilidade que, por sua vez, é, ou deveria ser, coletiva. Vale reproduzirmos suas palavras:

Na medida em que a criança não tem familiaridade com o mundo, deve-se introduzila aos poucos a ele; na medida em que ela é nova, deve-se cuidar para que essa coisa nova chegue à fruição em relação ao mundo como ele é. Em todo caso, todavia, o educador está aqui em relação ao jovem como representante de um mundo pelo qual deve assumir a responsabilidade, embora não o tenha feito e ainda que secreta ou 
abertamente possa querer que ele fosse diferente do que é. Essa responsabilidade não é imposta arbitrariamente aos educadores; ela está implícita no fato de que os jovens são introduzidos por adultos em um mundo em contínua mudança. Qualquer pessoa que se recuse a assumir a responsabilidade coletiva pelo mundo não deveria ter crianças, e é preciso proibi-la de tomar parte em sua educação. (ARENDT, 2011, p.239)

Sendo assim, interessa-nos compreender a inclusão de alunos com surdocegueira no contexto educacional atual, sem mantermos nossos limites dentro dos antigos padrões - o dito ideal de "normalidade". Tal proposta conversa diretamente com a perspectiva inclusiva assumida pela RME de São Paulo ${ }^{62}$. Portanto, quando falamos em educação, deve ficar claro que reconhecemos o requisito proposto por Adorno de não violência e, como característica essencial do educador, a capacidade de assumir a responsabilidade coletiva pelo mundo.

Dito isto, cabe uma breve explicação sobre a organização deste capítulo em quatro partes:

1. Apresentação das colaboradoras, onde foram organizadas informações sobre o percurso formativo e profissional de cada uma delas;

2. Emancipar e incluir; emancipar ou incluir?, que tem como foco a compreensão que cada uma das colaboradoras tem da educação, principalmente a educação na perspectiva inclusiva que nos deixa sempre frente à possibilidade da soma (e) ou da exclusão (ou);

3. O bilinguismo como modelo inclusivo, que parte da fala das colaboradoras sobre a Libras, para propor um olhar atento para a complexidade do modelo inclusivo presente nas escolas bilíngues;

4. Quem pode... quem não pode, propomos discussões sobre a categoria de normalidade dentro de uma escola que teve um passado como "escola especial" e que vem construindo sua identidade como "escola bilíngue". Nesse cenário, é importante pensar sobre a contradição da especialização, quando se analisa o perfil do educador em uma escola bilíngue.

Passemos, então, à apresentação das voluntárias que participaram da pesquisa e ao desenvolvimento das demais partes.

\footnotetext{
${ }^{62}$ É oportuno e necessário ao menos citar o Decreto no 57.379, de 13 de outubro de 2016, que "Institui no Sistema Municipal de Ensino a Política Paulistana de Educação Especial, na Perspectiva da Educação Inclusiva", regulamentado pela Portaria $\mathrm{n}^{\circ}$ 8.764, de 23 de dezembro de 2016. Uma análise aprofundada desses documentos, entretanto, ficará para estudos futuros.
} 


\subsection{APRESENTAÇÃO DAS COLABORADORAS}

Quatro mulheres, quatro educadoras, e utilizamos profissionais da educação porque, apesar de terem formações na área de Educação, como professoras, temos duas pessoas da equipe gestora ${ }^{63}$ - uma da direção, que identificamos como Sara, e outra da coordenação, aqui chamada Lídia - e duas professoras - uma do Ensino Fundamental II, Rute, e uma do Ensino Fundamental I, Ester.

Essa configuração merece atenção quando pensamos no bom funcionamento de qualquer unidade educacional. O papel do professor é importante, sem dúvida alguma, mas sem uma estrutura, sem a presença de uma gestão atuante, as ações pedagógicas podem acabar limitadas a um mínimo possível para sujeitos adultos independentes. Ou ainda, como Becker argumenta (ADORNO, 1995, p.177) "não tem sentido uma escola sem professores, mas [...] o professor precisa ter clareza quanto a que sua tarefa principal consiste em se tornar supérfluo".

A inclusão de alunos com surdocegueira envolve mais do que a ação individual de um professor, mas relevância dessas ações individuais não pode ser deixada de lado, já que compreendemos o ambiente escolar como um sistema, e acreditamos que algumas mudanças somente são possíveis em um sistema saudável. Na realidade, percebemos a sociedade como um sistema, e o bom funcionamento de uma unidade educacional - um sub-sistema -, exige elementos externos, muitas vezes invisíveis para quem vivencia o cotidiano escolar.

No caso da EMEBS estudada, não a estamos comparando com uma situação hipotética ideal. Estudamos uma situação específica que nos dá pistas sobre o sistema como um todo. E mesmo um sistema saudável pode, sim, ter conflitos internos, discordâncias - basta termos em mente o alerta de Adorno (1995, p.165) sobre a "passividade inofensiva", que também não deixa de ser barbárie - e até falhas no funcionamento. Tentamos trazer, em nossa análise, falas que ilustram formas de lidar com essas situações-problemas e que nos ajudaram a pensar sobre os dois eixos-questões principais.

Vamos, pois, à apresentação de cada uma dessas pessoas que nos cederam suas experiências profissionais e suas histórias, assim como parte de seu tempo, para compartilhar as informações que aqui são trazidas.

\footnotetext{
${ }^{63}$ As Unidades Educacionais da RME que atendem alunos nos três turnos - matutino, vespertino e noturno - têm uma composição de cinco gestores: uma pessoa na direção, duas pessoas que atuam como assistentes de direção e dois coordenadores. Quando esses cargos não são ocupados por profissionais concursados, eles podem vir a ser temporariamente ocupados por professores que atendam os requisitos necessários, por meio de votação do Conselho de Escola.
} 


\subsubsection{Sara}

Sara era a diretora da EMEBS - ainda então EMEE - quando chegou aquele que acreditava ser o primeiro aluno com surdocegueira. Sua fala traz inúmeras informações importantes, desde aspectos da educação, de forma geral, até esclarecimentos mais pontuais sobre o funcionamento da RME.

Sobre sua infância e adolescência, ela nos disse que estudou em uma escola particular, ainda na década de 1970. Porém, uma escola que tinha uma proposta diferenciada, sem a utilização de cartilhas como material didático e com uma organização espacial da sala de aula que já não era em fileiras de carteiras.

Sara: [...] a gente já não usava Caminho Suave, já era outro tipo de alfabetização, as salas não eram em... um atrás do outro, eram círculos, que eram formados. Isso, imagina, na década de 70. [...] a dinâmica das aulas era completamente diferente do que as aulas comuns. Então, um aluno era o secretário, o outro era o que cronometrava o tempo, e outro... então, a gente tinha assim, funções.

A escolha por essa escola se deu por conta da experiência materna como educadora. Sua mãe foi uma das professoras pioneiras da rede municipal e continuou tendo influência sobre a sua atuação profissional como educadora na rede pública.

Apesar de possuir especialização em administração escolar e ter cursado a pós-graduação em Inclusão da Pessoa com Deficiência, com ênfase em Surdez, já estando na EMEBS, foram os aprendizados durante sua vida escolar, como aluna, e durante sua atuação prática profissional, como professora e gestora, que tiveram maior destaque.

Sobre essas experiências, podemos trazer outros trechos de sua fala:

Sara: [...] então acho que essa minha formação de colégio, ela foi muito importante e a, também, as conversas em casa sobre educação pública, porque eu sempre, minha mãe sempre atuou na educação pública, e eu estudei na escola particular [...] mas eu acho por minha mãe ter escolhido por conta dessa educação inovadora. [...] E a gente sempre conversou muito em casa sobre a educação pública. Então, acho que isso fez muita diferença. 
Nesse contexto educacional vale destacar que, como aluna, Sara teve contato com pessoas com deficiência incluídos na sala de aula regular, em um tempo em que as salas especiais eram muito mais comuns. Segundo suas palavras,

Sara: E você sabe que no Colégio [...] a gente tinha alunos com deficiência incluídos na década de 70.

Essa lembrança era uma referência em sua atuação como educadora, paralelamente às conversas familiares referidas anteriormente. Sua fala reforça uma postura clara frente a todos os alunos, com ou sem deficiência, e que podemos resumir em uma frase: todos podem e devem estar na escola.

Sobre sua atuação profissional, importa registrar que Sara iniciou sua carreira como professora em 1984 e atuou na sala de aula até 1997, quando passou a compor a equipe gestora de uma Escola Municipal de Educação Infantil (EMEI) como assistente de direção, onde permaneceu por quinze anos. Desde então, sua atuação na gestão escolar perdurou até sua aposentadoria, envolvendo a aprovação em concurso específico para cargo de gestão.

Quando passou a atuar como parte da equipe gestora dessa EMEI, após dez anos como professora, a recepção de alunos com deficiência não lhe parecia algo a se questionar. Sara nos traz o seguinte relato sobre esse período.

Sara: [...] foi uma escola que teve assim, uma projeção muito grande na região como uma escola de excelência, e também pelo trabalho que fazia na inclusão das crianças com deficiência. Então nós tínhamos, né, histórias de pais que contavam que andavam uma peregrinação pelas EMEIs da região, que sempre diziam não ter vaga, ou dificuldade de atendimento, etc, e ao chegar lá na nossa escola, como a gente já tinha na equipe essa vontade de atender os alunos com deficiência, eles encontraram, então, um porto seguro nessa escola. Então, o meu trabalho com crianças com deficiência começou, na verdade, mais intensivamente aí, porque na minha história como professora, eu tive um caso de um aluno com deficiência, que foi meu aluno, e um caso de um aluno com superdotação. Então, era essa a minha experiência na sala de aula. Já na gestão, a gente conseguiu, nessa EMEI, atender vários alunos com deficiência. Era uma escola que tinha certa acessibilidade, apesar de ter dois andares, mas a gente também tinha, assim, funcionários, etc, que toparam compartilhar desse sonho com a 
gente. E eu fiquei quinze anos como assistente de diretor nessa escola. Então, foi assim, um trabalho que a gente conseguiu colher os frutos, né, da... do trabalho.

Após 25 anos na rede, Sara prestou um concurso para o cargo de Direção. Aprovada, optou por uma Escola Especial e continuou atuando nessa unidade até sua aposentadoria, cerca de seis anos depois. Conhecia apenas alguns sinais da Libras, aprendendo efetivamente a língua já como diretora dessa unidade.

Acompanhou ativamente a transformação de EMEE para EMEBS, assim como a inclusão dos alunos com surdocegueira nessa unidade educacional.

\subsubsection{Lídia}

Lídia se formou em Pedagogia, em meados da década de 1980, com foco em Orientação Educacional. Cursou uma pós-graduação em Psicopedagogia e deu continuidade à sua formação com outras três habilitações: em Administração Escolar, Supervisão e Deficiência Mental. Foi então, nos primeiros anos da década de 1990, que teve os primeiros contatos com pessoas com deficiência intelectual e física, durante os estágios dessa habilitação. E é ela mesma que esclarece: "o contato com o deficiente intelectual, que na época a gente falava mental, já começou nos estágios naquela época”.

Paralelamente a todas essas formações complementares, Lídia iniciou sua carreira como professora de turmas de educação infantil em uma escola particular, logo ao se formar. Atuou como professora da rede privada por dez anos, até 1996. Deixou a escola ao ser aprovada em um concurso para Coordenação Pedagógica na RME de São Paulo. A sua primeira escola, de lotação e exercício, na RME, foi uma Escola Municipal de Ensino Fundamental (EMEF) na região oeste da cidade de São Paulo, próximo ao local onde então residia. Nessa unidade educacional, trabalhou com a coordenação de professores do Ensino Fundamental I (FUND I), do Ensino Fundamental II (FUND II) e da Educação de Jovens e Adultos (EJA). Após dois anos, por conta de uma mudança de residência, solicitou remoção para uma unidade mais próxima a sua nova casa, onde ficou por mais dois anos, também atuando como coordenadora.

Cerca de quatro anos após seu ingresso na RME, no ano de 2000, Lídia foi convidada a trabalhar em uma das Diretorias de Orientação Técnica (DOT), na então Coordenadoria de 
Educação ${ }^{64}$. Entretanto, tratava-se de um trabalho no setor de compras e, segundo suas palavras, "não gostei muito de trabalhar porque era muito administrativo". Nesse mesmo ano, foi aprovada em um concurso para Supervisão Escolar em São Bernardo do Campo, um município vizinho à capital. Como se tratava de "uma experiência, também, que eu queria passar", e a convocação coincidiu com a saída, da coordenadoria, da pessoa que lhe havia convidado, Lídia também saiu, solicitou licença da RME de São Paulo e assumiu esse cargo de Supervisora Escolar.

Apesar de não ter um contato direto com o cotidiano escolar, pois como supervisora realizava visitas e acompanhava cinco ou seis escolas, dessa experiência, ela tem a lembrança de que a discussão sobre a educação das pessoas com deficiência "era muito adiantada, comparando com São Paulo". Porém, a distância e todas as funções relacionadas a esse cargo, fizeram com que optasse por retornar à RME de São Paulo, no último ano do governo de Marta Suplicy.

Nessa ocasião, a mesma equipe que já havia feito um convite para que atuasse em DOT, voltou a lhe propor a ida para uma coordenadoria que estava sendo criada. Este novo convite propunha uma atuação no setor de formação pedagógica e não mais em setores administrativos, o que lhe interessou. Ela voltou para a RME de São Paulo já nessa coordenadoria, onde participou como formadora, entre outras atividades mais relacionadas ao acompanhamento das unidades educacionais e de suas equipes.

Com o final do governo Marta, deixou a coordenadoria e passou a assumir a coordenação de um CEI (Centro de Educação Infantil), em um contexto em que a integração dessas unidades à SME era muito recente ${ }^{65}$. Porém, novamente, devido à mudança de residência, solicitou remoção e foi quando assumiu a coordenação de uma EMEBS, então ainda denominada EMEE, onde permaneceu por oito anos, também acompanhando a chegada dos primeiros alunos com surdocegueira nessas unidades.

Aprendeu Libras já como coordenadora dessa unidade, em um curso livre ofertado por uma instituição tradicional especializada em surdez.

Atualmente continua ativa na coordenação de uma EMEI, pois há dois anos solicitou remoção e saiu da EMEBS.

\footnotetext{
${ }^{64}$ Durante o governo de Marta Suplicy (2001-2004) na prefeitura de São Paulo, houve uma reestruturação que visava a descentralização administrativa intramunicipal, tendo as Subprefeituras como centros administrativos regionais. Podemos afirmar, de forma muito simplificada, que a Coordenadoria de Educação corresponderia às atuais DRE. Porém, estas são, hoje, treze e as subprefeituras atualmente somam um total de trinta e duas. Uma análise rica sobre essa questão pode ser encontrada em Grin (2015).

${ }^{65}$ Os CEI, antes denominadas creches, receberam essa nova denominação e passaram para a gestão da Secretaria Municipal de Educação em 2001. Ver decreto n 40.268, 31 de janeiro de 2001, que "dispõe sobre a efetivação de diretrizes de integração das creches ao Sistema Municipal de Ensino".
} 


\subsubsection{Rute}

Rute não pensava em fazer faculdade, por conta da realidade em que vivia: "Aquela preocupação em trabalhar, ajudar em casa, ajudar na família, e tal.” Porém, quando terminava o ensino médio, "surgiu a possibilidade de fazer o primeiro vestibular com gratuidade" 66 , conforme suas próprias palavras:

Rute: [...] resolvi entrar num cursinho popular na Poli, né, da Lapa, só que aí, sai da Zona Leste, vai pra Paulista, trabalha na Paulista, à noite, vai pra Lapa, acabou ficando tudo muito confuso, e aí veio o momento mesmo, né. Ou eu trabalho ou eu estudo. Sem trabalho não dava pra pagar o cursinho, então eu ia desistir, ... é, um amigo meu me ofereceu uma bolsa, no cursinho, pra trabalhar no cursinho em troca do... dos estudos, e foi uma decisão junto com a minha mãe, assim. Então, não posso mais ajudar em casa, não tenho mais dinheiro, mas vou ficar o dia inteiro fora, e vou estudar, e acabei fazendo um ano de cursinho assim, ficando o dia inteiro lá, e acabei passando na lista de espera da UNESP.

Ela graduou-se em 2004, em uma universidade pública, em um curso na área de humanidades, e, no mesmo ano, logo ao voltar para a capital, foi aprovada em um concurso público para atuar como professora da rede estadual de ensino de São Paulo. Rute assumiu o cargo e ingressou nesse mesmo ano. Depois de alguns anos, foi aprovada em um concurso da RME de São Paulo, para o cargo de Professora de Ensino Fundamental II e Médio.

Iniciou na rede municipal com um cargo, e depois, com dois, deixando o trabalho no Estado. Nesse meio tempo, chegou a atuar, também, como professora em instituições privadas de ensino e, paralelamente, de acordo com sua própria fala, nunca parou de estudar: "Tudo o que aparecia, e dava para eu fazer, eu fazia".

\footnotetext{
${ }^{66}$ Vale abrir um parêntese para destacar de sua fala a questão da isenção de pagamento da taxa de inscrição. O ENEM teve início em 1998. Essas medidas relacionadas às isenções foram um pouco posteriores. Porém, como nosso estudo está diretamente relacionado com a temática da democratização de acesso à educação, esses elementos precisam, ainda que brevemente, ser sublinhados.

$\mathrm{O}$ artigo intitulado "Políticas Públicas de democratização do acesso ao ensino superior e estrutura básica de formação no ensino médio regular" (CARMO et al., 2014), sistematiza várias informações relacionadas a esse tema. Sobre o ENEM e a isenção de pagamento, ver p.306-7.
} 
Realizou uma sequência de cursos de pós-graduação, sendo a primeira em História, Sociedade e Cultura, em uma universidade particular na cidade de São Paulo. A segunda especialização foi em Formação de Professores, em uma universidade pública no interior de São Paulo - em parceria com a Secretaria Estadual de Educação de São Paulo. O outro curso de especialização foi em deficiência auditiva, também em uma universidade pública paulista - em parceria com a SME-São Paulo. Sobre esta especialização, ela esclarece:

Rute: Na realidade, junto com esse de deficiência auditiva, tinha o de deficiência intelectual, né, eram as duas áreas. É... aí, eu me interessei pelo de deficiência intelectual, e acabei descobrindo que não podia fazer porque era voltado só pra professor de Fund I, e eu como professora de Fund II, só podia fazer o de deficiência auditiva. Então, já tava ali, né, eu já tinha me interessado no processo, e uma amiga minha ia fazer de deficiência auditiva, também, aí a gente acabou optando e fazendo juntas, que ia ser, seriam aulas aí na Sé. [...] o curso já tinha como pré-requisito [...] ir trabalhar nas EMEBS. Então, tanto que a entrevista pra conseguir a vaga do curso, era direto nas EMEBS. Então a gente foi, fizemos a entrevista, fomos selecionados, e aí começamos a fazer o curso. E aí muitos, durante o percurso, já foram na EMEBS, já foram conseguindo ou fazer estágio, ou conhecer, é... ou indo, né, até, trabalhar, antes e eu fui só depois do término do curso, porque eu morava na zona leste e era muito longe. E aí, fui, sem língua, né, sem língua de sinais totalmente apropriada, e foi bem difícil, no primeiro ano, e aí que começou todo o processo de conhecer esse mundo novo.

Foi durante esse curso de especialização que começou a aprender Libras, um dos componentes curriculares dessa especialização. Chegou a frequentar, também, um curso livre de Libras, mas deixou o mesmo porque não atendia às suas necessidades como professora na sala de aula.

Mas a formação continuada não se encerrou aí. Já como professora da EMEBS, Rute cursou outra especialização, agora para alunos com deficiência múltipla e surdocegueira. Dessa forma, passou a atuar, em um cargo, como professora e, no outro cargo, como guia-intérprete educacional de alunos com surdocegueira, e continua atuando em EMEBS. 


\subsubsection{Ester}

Ester sempre estudou em escola pública. Tem boas lembranças das escolas, desde quando ingressou no pré, em 1976, até o magistério. Ela reforça: "eu tive professores muito bons. É... escolas boas também."

Devido a essas experiências positivas, a vontade de ser professora surgiu no fundamental I e perdurou como uma convicção:

Ester: Sempre gostei muito de criança, então eu falei, ah, eu quero ser professora. E aí, depois, quando eu terminei o fundamental, fui direto pro magistério, consciente mesmo, que eu queria fazer isso, então, já, parti para o magistério, né, na parte técnica. Eu nem fiz o colegial normal, [...] na época eram quatro anos de magistério, o primeiro ano era básico, o colegial básico, depois já ia para o magistério.

Logo depois do magistério, Ester iniciou o curso de pedagogia em uma universidade particular: "foi pra firmar mesmo, a mesma faculdade, a mesma área, porque é isso que eu gostava. Pra ter a parte de nível superior, né, não ia fazer outra coisa. Era convicção mesmo."

Conciliou o ensino superior a um trabalho como professora em uma escolinha particular, com crianças pequenas, o que lhe garantia o pagamento da mensalidade da faculdade $-\mathrm{e}$ a escolha por essa universidade particular se deu por conta da localização, pois ficava mais próxima à sua residência.

Não teve dificuldades, pois contava com uma boa base vinda de sua formação no magistério e com a experiência prática de seu trabalho.

Seu contato com a língua de sinais teve início em 1988, na Igreja Batista, em um curso oferecido na igreja.

Ester: Pois é... e aí começou, teve o curso lá, tal, movimento do curso de Libras, naquela época, e eu meio curiosa, né, no segundo curso de Libras que teve, eu entrei, para saber o que que era. Ah! Eu quero saber que negócio é esse curso, tal, e aí comecei a gostar, muito, assim, da questão, de, né, de sinais. Naquela época nem era tanto, só Libras, era mais... ah... português sinalizado, ainda tava caminhando, né. 
Ester ainda nos lembra que na época não se falava em língua de sinais, muito menos em Libras. A nomenclatura então utilizada era "linguagem de sinais". O seu interesse pela língua passou a crescer, pois com o curso, alguns Surdos passaram a frequentar sua igreja. Apesar de ainda não ser reconhecida como língua, Ester defende "é, não deixa de ser, é uma língua. Já era. Não era tão estabelecida como língua, mas já era língua, né?"

Em sua narrativa, Ester traz informações ricas sobre outras questões, a partir de sua vivência. A discussão sobre gênero e deficiência aparece como marcas do contexto que mereceriam uma consideração, mas apenas apontamos rapidamente, trazendo suas palavras sobre as pessoas que começaram a frequentar a igreja. Eram, principalmente, homens:

Ester: porque nessa época, as mães não liberavam ainda, as meninas. Porque não sabiam o que que era. Não era muito comum. O homem não. Por si mesmo, o rapaz surdo, andava sozinho, então, aí eles começaram a chegar, e... lá na igreja, tal, a gente fazendo como intérprete. Já comecei, né, caminhar como intérprete. Que é assim, eu sou uma pessoa que não tenho vergonha, né.

E em uma identificação natural com a Cultura Surda, Ester passou a relacionar-se com Surdos:

Ester: Não tenho vergonha, não tenho nada. Então onde tinha Surdos, eu via Surdos na rua, eu falava com eles. "Oi oi!’. "Ah, cê é surda?” E eu falava: “não, sou ouvinte”. “Ah! Cê tá...” Ai eu falava: “calma, tô aprendendo”. Mas aí eu ia mesmo. Não tinha medo, né. Se eu via que era Surdo, eu me metia e conversava, tal. Para conhecer. E aí, assim, fui pegando esse contato, e esse contato.

Mas o seu convívio não se limitava a esses encontros eventuais. Passou a frequentar, junto com sua professora da igreja, as festas juninas das escolas de Surdos tanto das escolas municipais de São Paulo - então EMEE -, como algumas instituições particulares: "cada uma fazia num sábado, então a gente ia em todas, para ter contato com Surdo”.

Ester continua com um olhar crítico à própria atuação junto aos Surdos que frequentavam sua igreja: "então a gente começou já a interpretar daquele jeito que era, antigamente, né, mais assim, ainda sentado, sem muito conhecimento, né”. Ao mesmo tempo, mostra a importância desse espaço que promovia ações que propiciavam o uso da língua de sinais e, desta 
forma, a aquisição da mesma pelos próprios Surdos, pois além dos cultos na igreja, eram promovidos passeios, viagens e acampamentos.

Esse contato com a língua de sinais e com as escolas, fez com que Ester decidisse buscar, em 1996, uma especialização, com a duração de um ano, na área de pedagogia chamada EDAC - Educação do Deficiente da Áudio-Comunicação. Tratava-se de um curso específico sobre a deficiência auditiva: "Todas as matérias voltadas só para o surdo. Então era anatomia, era fono... audiologia, tudo relacionado ao surdo. Didática. Tudo, porque era próprio, só pro surdo. " 67

O seu conhecimento prévio na língua fez com que um grupo de colegas dessa especialização organizasse, informalmente, em um horário vago comum, um curso de língua de sinais com ela. Isso porque, durante os estágios, o fato dela saber a língua, lhe permitia contato direto com os alunos, pois a comunicação acontecia e isso chamava a atenção de seus colegas.

No ano seguinte, a nova turma voltou a cobrar o ensino da língua de sinais: "Porque não tinha mesmo, na grade curricular [...] aí, alguém disse: Ah! Mas tinha uma aluna, tal, que no ano passado, deu curso... é."

Ester recebeu, então, um convite para dar aulas nesse curso:

Ester: Aí, eu acabei indo, e fiz o plano pra ir pro MEC, para entrar na grade curricular, que é o plano de três anos. Você tem que dar aula daquela matéria, pra depois ela poder entrar. E aí eu fiz esse plano, lá, com a faculdade, e comecei a dar [...] só que aí, em noventa e nove, eu entrei na prefeitura. E aí, o que que acontecia, eu tava lá também, ainda, mas eu tive que deixar.

Sua fala e tom de voz demonstram muito orgulho e gratidão ao falar dessa experiência, que define como “ótima”. E sua opção pelos dois cargos na rede municipal, não foi precedida de uma busca por outra pessoa que pudesse assumir as aulas de língua de sinais nesse curso de especialização. Na ocasião, Ester defendeu e explicou a importância de se buscar uma pessoa surda, e indicou uma pessoa, com as especificações necessárias: formação universitária.

Com a aprovação no concurso, Ester escolhe, já inicialmente, para os dois cargos, uma EMEBS, então EMEE, onde continua como professora nos dias atuais.

\footnotetext{
${ }^{67}$ Neste trecho da transcrição, mantivemos surdos em minúscula, porque apesar de fazer referência aos surdos, pela fala de Ester, é possível notar que tratava-se de uma especialização em deficiência auditiva. Essa diferenciação será importante na discussão teórica que propomos na segunda parte do capítulo final. E vale atentarmos para o fato dessa professora ter provocado transformações nesse curso de especialização que, após sua turma, passou a voltar-se mais para a questão dos Surdos ao incluir a disciplina de Libras.
} 


\subsection{EMANCIPAR E INCLUIR; EMANCIPAR OU INCLUIR?}

Nesta parte da pesquisa, buscamos excertos das falas das colaboradoras, que permitem pontuar, a partir de cada uma das conversas, qual a concepção de educação que se nota nos relatos sobre suas ações e histórias. Interessava-nos identificar se, em algum ponto, essa compreensão evidenciava uma preocupação com o princípio da não violência e como ou se isso se objetivou no cenário inclusivo escolhido.

A partir da leitura das transcrições das entrevistas, foram elegidas palavras que sintetizam a concepção de educação e, ao mesmo tempo, analisam esse conceito de forma conectada com a rede municipal como um todo ${ }^{68}$. São elas: direito, acolhimento, respeito e responsabilidade. Nós as utilizamos como subtítulos que têm uma personagem-colaboradora como foco central para as discussões - respectivamente Sara, Lídia, Rute e Ester -, mas todas as colaboradoras estão presentes, de forma entrecruzada, direta ou indiretamente.

Essas palavras nos permitiram pensar sobre as conjunções $e$ e $o u$, respectivamente aditiva e alternativa, propostas no título. Emancipação e inclusão são complementares? Ou são escolhas excludentes? Que se alternam?

O mote para a discussão será a inclusão dos alunos com surdocegueira na RME de São Paulo, tendo como ponto de partida a chegada do "primeiro" aluno com surdocegueira em uma das EMEBS.

\subsubsection{Educação como direito}

Quando da chegada desse "primeiro" aluno com surdocegueira na EMEBS, então ainda denominada EMEE, Sara, a diretora, nos relata a importância do contato entre as equipes gestoras da EMEE com a de uma instituição conveniada à Prefeitura de São Paulo, que atende alunos com deficiência múltipla e surdocegueira. Foi a diretora desta instituição que procurou Sara e lhe perguntou sobre a possibilidade de atender um aluno com surdocegueira, que até então frequentava apenas a referida instituição, em sua modalidade escolar. Sara nos conta:

Sara: eu de pronto falei: "Nossa, um desafio, assim, muito legal”.

\footnotetext{
${ }^{68}$ A leitura do decreto $\mathrm{n}^{\circ}$ 57.379, de 13 de outubro de 2016, e da Portaria $\mathrm{n}^{\mathrm{o}} 8.764$, de 23 de dezembro de 2016, nos fornecem argumentos para esta afirmação. Evidentemente, uma análise mais aprofundada permanece como uma etapa a ser considerada posteriormente.
} 
Como diretora, logicamente, eu vi que fazia parte do público alvo de atendimento da EMEE, na época, que não era EMEBS, né?! Mas já como EMEE, estava previsto o atendimento ao surdocego e ao Surdo com outras deficiências associadas. Quando transformou em EMEBS, carregou essa mesma, ah... o mesmo público alvo, mas na EMEE já estava previsto isso. Então, eu estando com a legislação me amparando para trazer esse aluno, com o apoio da Mariana, que era diretora da [nome da instituição], e com a obrigação, na verdade, que eu tinha de receber esse aluno, mais o desafio que eu gosto muito de enfrentar, a gente, então, optou pelo acolhimento do Fábio naquele momento, na escola.

De um lado, Mariana, diretora dessa instituição conveniada à Prefeitura, com anos de experiência em educação especial. Do outro, Sara, diretora de uma escola da rede pública que assumia um posicionamento pela inclusão de alunos com deficiência. Ruptura, desafio e imprevisibilidade.

Apesar das orientações legais, ainda hoje vivemos em um contexto onde há falas contra a inclusão de alunos com deficiência, ou de alunos vindos de comunidades periféricas, ou que apresentam comportamentos considerados inadequados, baseadas no argumento de que alguns não podem ser incluídos porque "vão prejudicar os demais" - uma suposta maioria homogênea -, e porque vão atrasar a sala, ou vão “onerar” os gastos, ou ainda, porque é melhor mantê-los protegidos e tutelados, já que os professores não estão preparados ${ }^{69}$.

Há algo de traiçoeiro nesse discurso com o qual Sara não se mostrou conivente e sua postura, inicialmente contra a "tradição", merece consideração, pois há cerca de dez anos, a crença na segregação refletia uma fala ainda majoritária, uma resposta pronta e aceita pela grande maioria da sociedade.

A chegada dos alunos com surdocegueira provoca uma crise, como compreendida por Arendt (2011, p.223): que "nos obriga a voltar às questões mesmas". Não basta afirmar que a sociedade era preconceituosa, ou que as pessoas não aceitavam mudanças.

A segregação e a discriminação nada mais fizeram do que impor anseios às pessoas, que hoje sabemos serem artificiais, tendo como referência um ideal de vida de minorias privilegiadas. Poderíamos traduzir anseios também como necessidade de consumo para a garantia do

\footnotetext{
${ }^{69}$ Basta fazer uma busca na internet sobre um conjunto de notícias deste ano de 2016 sobre um "pedido da Confederação Nacional dos Estabelecimentos de Ensino (Confenen) para derrubar obrigação de as escolas privadas se adaptarem para receber pessoas com deficiência no ensino regular”. (RAMALHO, 2016)
} 
prazer e da felicidade. Já em 1969, quando Adorno e Horkheimer (1985, p.168) escreveram sobre o progresso da sociedade industrial, da qual deriva a mentalidade do ticket, puderam perceber a loucura presente nesse tipo de mentalidade. A pauperização, compreendida como uma dor que poderia ter sido eliminada, passa, de forma oposta, a ser alimentada. Isto porque a irracionalidade, a escolha do ticket, "significa adaptar-se a uma aparência petrificada como uma realidade e que se prolonga a perder de vista graças a essa adaptação.” (ADORNO; HORKHEIMER, 1985, p.169)

A tradição dizia: "vamos mantê-los nas instituições", mas com a "crise", a volta à questão mesma trouxe uma nova resposta. Hoje, muito mais pessoas acreditam que todos, sem exceção, devem ter acesso à educação formal em instituições de ensino públicas.

É essa reflexão, que se objetivou por meio de ações concretizadas nas EMEBS, que nos interessa. Ações que caminharam em sentido oposto ao de uma adaptação à "realidade" como estava posta, transformando-a. Ações que evidenciaram a "mentira manifesta" (ADORNO; HORKHEIMER, 1985, p.171) contida na lógica da mentalidade do ticket. As reflexões sobre a inclusão devem atentar para a necessidade de se romper e se libertar dessa mentira; pois ela abre uma via possível para a emancipação ao evidenciar o valor de toda e qualquer pessoa, de toda e qualquer vida. Ela alerta para a necessidade de desprendimento dessa "aparência petrificada como uma realidade" de que nos falam Adorno e Horkheimer (1985, p.169).

A análise de Adorno e Horkheimer (1985, p. 51-52) sobre a troca como a secularização do sacrifício, abarcam essa herança histórica de segregação das pessoas com deficiência. No caso, a aparência petrificada é, entre outras crenças, a de que é correto separar os melhores alunos para assegurar a sua excelência, o seu rendimento. O sacrifício de uns - a exclusão -, para o sucesso de uma parcela que a sociedade industrial acredita ser necessária e que deve receber o devido mérito pelo seu esforço e talento. O sacrifício, "marca de uma catástrofe histórica, um ato de violência que atinge os homens e a natureza igualmente" (ADORNO; HORKHEIMER, 1985, p.52).

E se as instituições educacionais têm apostado no desempenho e competitividade, não podemos deixar de perceber que tal pensamento reflete, também, a busca dessas instituições por pais e responsáveis que coadunam com esses valores. Sim, o ingresso em cursos superiores é importante e necessário; no entanto, quando se pensa em formação, a educação não pode se resumir a uma etapa acadêmica da vida, principalmente quando algumas instituições envolvidas passam a ter como foco o tornarem-se negócios rentáveis. 
A tão exigida "educação de qualidade" deve contemplar a pluralidade humana, pois a qualidade não pode funcionar seguindo a lógica dos privilégios de uns, em detrimento dos outros. Em um cenário excludente, a perspectiva inclusiva sofre o risco de manter-se refém da origem etimológica latina da palavra inclaudere, que remete à ideia de colocar dentro de uma clausura. Isto é, acreditar em um único modelo universal de educação significa manter-se preso ao significado estrito da palavra, sem conseguir acessar o conceito de forma conectada com o princípio democrático, com a verdadeira liberdade.

Acreditar que o sucesso da educação de uma pessoa com deficiência é o seu ingresso em uma universidade, significa continuar preso a um padrão único, a uma "aparência petrificada". E o outro extremo também deve ser considerado: restringir a vida de uma pessoa com deficiência a um espaço "protegido", com atividades limitadas a trabalhos manuais, não seria mais do que perpetuar a herança assistencialista que Silveira Bueno (2011) critica de forma complexa em sua pesquisa. E retomando novamente as palavras de Adorno e Horkheimer, não seria mais do que um sacrifício, uma catástrofe histórica, um ato de violência.

Para que se possa superar a catástrofe e a violência, é necessário romper as fórmulas. Adorno e Horkheimer (1985, p. 136-138), ao pensarem sobre a publicidade e a indústria cultural, já alertavam para o momento em que "a palavra, que não deve significar mais nada e agora só pode designar, fica tão fixada na coisa que ela se torna uma fórmula petrificada.” E é nesse sentido que inclusão não pode ser um mero termo da moda, repetido e reproduzido de forma vazia. Essa palavra exige um resgate do laço entre a experiência e a linguagem, e é este laço que permite a sua não petrificação, a sua compreensão para além do consumo de uma ideia em voga. Afinal de contas, não se trata de ser livre para fazer o mesmo; e não se trata da "liberdade de escolher o que é sempre a mesma coisa".

Portanto, quando Sara tem por base a legislação e não questiona "se" poderia incluir esse aluno, assume seu papel de gestora, de forma condizente com os princípios da educação para todos. E não se trata de "passividade inofensiva" (ADORNO, 1995, p.164), e nem utilizamos aqui "papel de gestora" com o sentido de não-identidade, ou como uma "versão normativa do conceito de papel” (ADORNO, 1995, p.178). Sua narrativa nos faz crer em uma persecução dos interesses dos alunos excluídos. Isto pode parecer pouco e óbvio, mas sabemos que, ainda hoje, o para todos, em muitos contextos, traz uma série de requisitos que restringem o "todos" apenas a parte do todo. Tendo em vista que as EMEBS seguem um sistema diferenciado de matrícula para evitar alunos que não tenham perda auditiva, essa atitude de Sara tornase mais significativa. 
As demais unidades educacionais da RME de São Paulo recebem alunos cadastrados automaticamente em um sistema único virtual automatizado que indica as vagas de acordo com a proximidade da residência e a data do cadastro. Já as EMEBS, para assegurar o controle das matrículas vinculado à condição da perda auditiva, apesar de seguir esse sistema geral do município, tem uma "lista de espera" própria, pois é solicitada, entre os documentos para a matrícula, os resultados de um exame audiométrico. Isso dá à secretaria de cada uma das seis unidades considerável autonomia para a efetivação das matrículas.

Se a perspectiva inclusiva vem sendo difundida desde a década de 1980, não podemos deixar de perceber como a efetivação das matrículas precisaria fazer parte do sistema virtual, pois como Silveira Bueno (2011) evidencia em seu estudo, nossa história foi marcada por modelos que valorizaram entidades filantrópicas assistencialistas especializadas em deficiências, seguindo modelos segregacionistas. Portanto, o sistema de matrículas é um ponto importante a se pensar e Sara, como gestora, percebia essa importância.

Sara: Isso também era uma coisa que eu quis mudar e não consegui, que era a demanda da EMEBS ser igual à demanda que é feita na rede. Porque a demanda da EMEBS não é aberta, infelizmente. Então, se fosse, o aluno era matriculado automaticamente, e não é.

E ela complementa:

Sara: Eu não acho correto, também. Acho que devia que ter uma mudança ... assim, né?! A entrada é essa, a matrícula. Se você tá brecando ali na entrada, alguma coisa tá errada, né?! Tem que estar aberto, isso aí, que... pelo que eu sei, não tá aberto até hoje.

Essa característica confere duas facetas à questão: a discriminação pode ser uma forma de se assegurar direitos, mas pode, também, privar de direitos. Possivelmente isso fez com que a ideia da chegada de um aluno com surdocegueira soasse preocupante, ou, no mínimo, estranha para os professores acostumados com um público consideravelmente homogêneo de alunos Surdos, já que com o critério, que até então era entendido como sendo a surdez, poucos alunos com outras deficiências associadas eram matriculados. Isto é, conforme o histórico estudado por Silveira Bueno (2011), as EMEE eram escolas para Surdos, com professores especialistas nessa condição. A partir do momento em que a educação começa a perceber que não precisa de 
especialistas em deficiências e sim em educação de pessoas, essa lógica tão bem descrita por Silveira Bueno passa a ser mais e mais questionada. Nesse sentido, é importante notar que nos deparamos novamente com a necessidade de desprendimento daquela "aparência petrificada como uma realidade", à qual todos estamos submetidos.

Sara: Num primeiro momento, os professores tiveram a mesma reação que o professor da rede comum tem em receber um aluno com deficiência. Eles falavam: não temos formação para trabalhar com cegos, não sabemos braile, não sabemos especificidades dessa deficiência, e não queremos trabalhar com alunos cegos. Estudamos para trabalhar com Surdos, apenas.

Dessa forma, certamente, a chegada desse aluno não se deu de forma passiva e tranquila, sendo que passividade e tranquilidade não podem ser compreendidos como reações necessariamente positivas. Sem a mobilização dos profissionais da EMEBS - e não importa se por conta da insegurança ou medo - conquistas significativas, com o apoio da Secretaria de Educação, para assegurar o direito dos alunos com surdocegueira, talvez não tivessem ocorrido.

\begin{abstract}
Sara: Nós conseguimos junto com a Secretaria da Educação, fazer com que esse aluno surdocego fosse considerado como se fosse uma classe pra atribuição de aula. Então, quem tinha o curso, podia escolher esse aluno pra ser guia-intérprete dele, como se fosse uma classe.
\end{abstract}

O que nos parece significativo, nesses excertos, é a garantia do direito desse aluno estar nessa escola. Garantir essa presença, é uma forma de se opor ao sacrifício como compreendido por Adorno e Horkheimer (1985, p.52):

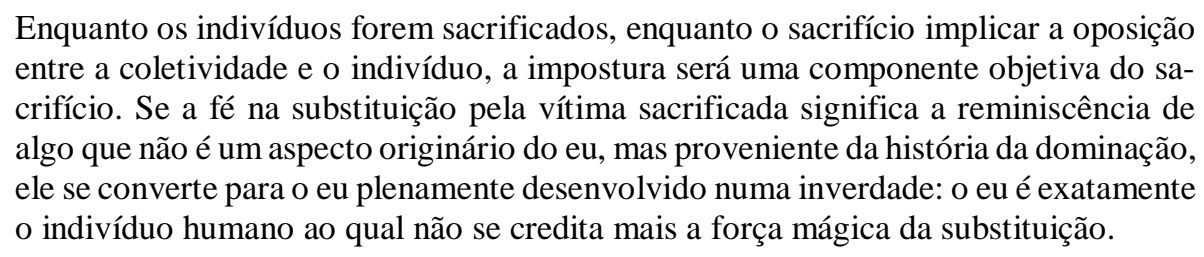

E um pouco adiante, esses autores nos permitem compreender quando as próprias pessoas com deficiência acreditam nessa mentira imposta. 
[...] A fé venerável no sacrifício, porém, já é provavelmente um esquema inculcado, segundo o qual os indivíduos subjugados infligem mais uma vez a si próprios a injustiça que lhes foi infligida, a fim de poder suportá-la. (ADORNO; HORKHEIMER, 1985, p.52)

A fala de Lídia reforça essa atitude de Sara para garantir a chegada desses alunos com surdocegueira.

Lídia: Porque é assim: a Sara era uma pessoa muito legal, assim, muito interessante. Porque ela entrou, mas ela entrou pra... é como se ela quisesse abrir as portas do [nome da escola]. Então, acho que ela foi revolucionária, no meu ponto de vista, porque antes dela tinha um caminho e, depois dela, um outro caminho do tipo: escola para todos. E nessa escola para todos, incluía até o múltiplo e o deficiente intelectual. Não foi muito fácil, porque uma coisa é você trabalhar com... só Surdo, que elas falam, até hoje elas falam "Surdo puro”, o Surdo. Assim, você ter o Surdo associado a uma outra deficiência, é uma outra... um outro trabalho. Um desafio. Isso começou a ser muito falado na época, que a escola tinha que acolher, mas não foi muito fácil. Porque é a questão da inclusão. Seria uma inclusão dentro da nossa escola. "Ai, como que eu vou trabalhar com uma criança autista, surda?" "Como que eu vou trabalhar com uma criança deficiente intelectual?" Ai, então, muito difícil. Ai, começaram as parcerias. Ela falou: "Vamos abrir a escola mas vamos procurar parcerias. " Então eu falo que a Sara foi revolucionária porque ela começou a fazer mil contatos. Então, sempre ela, ali. Contatos... e os contatos cada vez mais intensos e principalmente com a Mariana.

O acesso à educação como um direito, como uma possibilidade de rompimento com os antigos sacrifícios, como um combate a atos de violência silenciosos e generalizados inspirados em antigas respostas. E se essa atitude inicial da equipe gestora provocou incômodo, as professoras mostraram-se pessoas dotadas de resiliência, capazes de estabelecer novos julgamentos e de constituir novas respostas. Mas antes de trazermos as falas das professoras, veremos o que nos disse a coordenadora Lídia. 


\subsubsection{Educação como acolhimento}

Lídia atuava, quando da chegada de Fábio nessa unidade educacional, na coordenação. Em parceria com o restante da equipe gestora - direção e assistência de direção, assim como com a outra coordenadora - e com os professores, começou a buscar respostas para o desenvolvimento do trabalho com esse aluno.

Lídia: A única coisa que pegou foi isso: a gente acolhe, como é que faz? Aí, foi o seguinte combinado. Ele vai vir, e a gente dá a formação pros professores. Beleza. Então, aconteceu a coisa simultânea: a chegada do Fábio e a formação das educadoras. No caso, a gente começou pela formação da professora que ia pegar, que o Fábio ia entrar. Então, ele ia entrar na sala da Ester, na época, então a Ester recebeu a formação.

Mas, como qualquer situação de mudança, houve uma série de conflitos. Talvez por isso, a informação de que Ester, que acabou assumindo a turma na qual Fábio foi incluído ${ }^{70}$, já tinha realizado um curso sobre surdocegueira, no ano anterior, sequer tivesse sido passada à equipe gestora.

Se por um lado Sara pensava na garantia dos direitos dos alunos, seguindo as orientações legais, por outro, sua convicção não era, desde o início e de imediato, compartilhada por todos.

Lídia: Eu sei que no começo, quando a gente avisou os professores de que teríamos um surdocego, foi bem difícil, essa notícia. Porque as coisas foram acontecendo e ela, a Sara: "Vai ser assim. Tem que ser assim. A escola tem que estar aberta. " Então não teve uma preparação prévia. Ai, gente, olha, precisamos dar uma notícia, vai acontecer isso... não. A gente foi recebendo e foi fazendo, e foi tudo muito rápido, e foi tudo também muito sofrido, em alguns aspectos, né?! Eu acho que, por parte dos professores, meio assustador.

\footnotetext{
70 "Acabou assumindo" porque a professora que havia escolhido essa turma precisou ser readaptada por questões de saúde. Ester, que estava em módulo e era a primeira a escolher na sequência, assumiu como professora regente. Sobre o módulo de docentes, ver Portaria ${ }^{\circ}$ 4.194/08 da SME de São Paulo.
} 
Novamente, Arendt (2011, p.223) nos fornece elementos para pensarmos sobre a crise: a necessidade de se romper com antigas respostas; a urgência de enxergar na experiência, a oportunidade de reflexão. E reflexão gera conflitos, porque é o retorno à questão mesma.

No cenário estudado, o “assustador” estava sendo alimentado por considerações de uma outra professora da unidade que já havia tido experiências com alunos com surdocegueira.

Lídia: [...] ela tinha uma experiência com surdocegueira, e essa, ela é uma professora que eu sei que tinha, ela... comentava: "Não é fácil." Porque, o caso do Fábio, a gente diz que é um caso à parte, porque o surdocego geralmente tem uma complexidade. Não vem... não é só surdocego, ele tem outras questões, né. [...] Mas o que ela trazia pra gente: "Ai, muito dificil, uma coisa complexa, muitas questões..."

Isto é, essa professora que já tinha atuado com alunos com surdocegueira, compartilhava comentários sobre as especificidades desses alunos, de forma generalizada, sem sequer ter tido qualquer contato prévio com Fábio.

Aqui, podemos abrir um parêntese para reforçar: o atendimento educacional de qualquer aluno com surdocegueira implica, antes de qualquer "comentário" ou "caracterização", em uma avaliação pedagógica e uma conversa com os familiares. Essa professora que já conhecia alunos com surdocegueira, trazia a versão única ${ }^{71}$ de uma história que considerava representativa. Recorrendo às palavras de Amaral (1998, p.16), essa versão única era uma "generalização indevida", um mito com direito a um castelo cercado por crocodilos.

A chegada de Fábio e o contato direto com ele, fez com que os falsos mitos e essa "versão única" fosse apagada. As palavras de Lídia mostram como acontece uma rápida revisão desses juízos pré-formados e herdados da fala daquela professora:

Lídia: A gente começou também imaginando, antes do Fábio chegar, um milhão de coisas. Já começou a sofrer por antecipação. O que é natural. Surdocego... não... não sei... e aí, quando o Fábio chegou, e começou o trabalho com o Fábio,

\footnotetext{
${ }^{71}$ Fazemos referência à fala de Chimamanda Adichie na TedTalk intitulada "O perigo de uma única história". Dessa fala, podemos trazer um trecho onde ela afirma: "A história única cria estereótipos. E o problema com estereótipos não é que eles sejam mentira, mas que eles sejam incompletos. Eles fazem uma história tornar-se a única história.[...] Faz o reconhecimento de nossa humanidade compartilhada difícil. Enfatiza como nós somos diferentes ao invés de como somos semelhantes." Disponível em: https://www.ted.com/talks/chimamanda_adichie the danger_of a single story?language=pt-br. Último acesso em: 7 nov. 2016.
} 
as coisas começaram a ficar muito mais tranquilas, porque o Fábio respondia a tudo. Ele é um menino maravilhoso. [...] aí, começou, todo mundo a ficar apaixonado por ele.

“E começou o trabalho com o Fábio." Educação como acolhimento, que remete não apenas ao sentido mais comum de receber, mas também de levar o outro em consideração, conhecer e romper juízos pré-formados. Afinal de contas, quando resgatamos sua origem etimológica, percebemos que acolher é também aceitar e encarregar-se de (TORRINHA, 1994, p.730).

E foi isso que Ester, a professora regente da sala em que Fábio foi incluído, fez: acolheu. Lídia chama a atenção para essa personagem.

Lídia: a Ester é uma pessoa que foi fundamental, também, pra essa acolhida. Por quê? Porque ela é uma pessoa muito bem vista na escola, tem o domínio da língua, muito grande, intérprete também, então, ela começou. "Ai, será que eu vou dar conta?" Ela começou a dar conta e viu essa, como é que eu vou dizer... do Fábio, essas respostas do Fábio. E ela fala isso pro grupo: "Gente, vocês não sabem! Gente, olha!' Ela começou a ficar tão feliz, tão feliz daquilo que ela fazia que aí, não teve jeito. [...] Contaminou. Contaminou. Talvez se fosse, eu fico pensando, se fosse uma outra profissional...

Ela, realmente, a Ester, ela abraçou, né?! Ela estudou, se formou. Ela e a Luciana, elas foram, acho que, eu penso que foram... como professoras, precursoras.

Note-se a percepção de Lídia quando traz a fala de Ester, ainda insegura “Ai, será que eu vou dar conta? " E a partir dessa insegurança, as ações, as reflexões, e as respostas do aluno, que passaram a alimentar novas ações e o envolvimento de outras profissionais. Sim, envolvimento de outras professoras. E envolver é viver, porque é estar entre! (ARENDT, 2010, p.9)

Arendt nos lembra: "uma vida sem discurso e sem ação [...] é literalmente morta para o mundo; deixa de ser uma vida humana, uma vez que já não é vivida entre os homens.” Talvez, o papel fundamental de Ester tenha sido a desse compartilhamento; dessa "contaminação". Pelo discurso e pela ação: “Gente, vocês não sabem! Gente, olha!” Com palavras e com atos. E não deve ser coincidência o fato de que agir "em seu sentido mais geral, significa tomar iniciativa, iniciar”. (ARENDT, 2010, p.221) 
Sara nos conta sobre as mudanças percebidas nos professores que foram realizar formações complementares junto à instituição conveniada e sobre a atuação conjunta que contou com a mobilização de toda a equipe, e não apenas por aquelas que estavam atendendo o aluno com surdocegueira. Isto é, a mobilização de uma equipe que era composta por especialistas em educação:

Sara: Ele foi para a formação e voltou diferente. Isso que foi legal. Quando ele ia pra formação, ele voltava com outro olhar pro atendimento desse aluno. E a adaptação de materiais foi bárbara porque a coordenadora pedagógica iniciou um projeto em JEIF, onde os outros professores ajudavam na confecção de materiais que não existiam. Esse material não existia. Então... Livros, por exemplo, o professor da classe lá do Ensino Fundamental tava trabalhando "Menina bonita do laço de fita". O "Menina bonita do laço de fita" foi feito o livro inteiro em braile e tátil. Outro livro era trabalhado, o livro inteiro era feito... tanto que até hoje a gente tem lá na escola esse material e o material também em braile que nós fizemos em EVA, nós começamos bem grandão porque ele foi alfabetizado em braile. E as professoras viram também, nesse aluno e nesse novo atendimento, uma possibilidade de, ... crescimento, vamos dizer assim, profissional, e reconhecimento do trabalho.

Isto é, apesar do receio e da insegurança - que nos parece compreensível -, e mesmo do rechaço inicial, a ação coletiva permitiu uma construção pedagógica extremamente significativa para todos. E isso é acolher de forma respeitosa. Isso é tomar consciência. Tomar no sentido de pegar em suas próprias mãos, e dessa forma gerar uma energia que pode assumir aspectos políticos, como nos provoca a pensar o artista Víctor Grippo com sua instalação Analogía I, o Energía [1977/2014]. (GIL, 2016)

Essa obra nos interessa particularmente, pois vemos exatamente o coletivo de educadores gerando uma transformação. Há disputa de espaços, há conflitos de valores, há insatisfação, mas há permanência coletiva e há ação coletiva. Isto é, não se tratava apenas de um adulto, mas de adultos dispostos a aprender uma nova forma de estar no mundo e compreender essa diferença, para então apresentá-lo para o aluno. 


\subsubsection{Educação como respeito}

Se acolher bem é respeitar, como se pode "medir" se se respeita um aluno com deficiência incluído em uma escola?

Quando pensamos em escolas regulares da rede, é muito comum a associação entre os alunos com um profissional específico: a professora da SAAI, a AVE, ou a professora "que sabe lidar", a "professora que o aluno gosta". Talvez, esse dado seja um bom ponto de partida relevante. A fala da professora Rute nos traz informações sobre esse aspecto:

Rute: a gente tava até conversando, né, que tem muitos professores em muitas escolas que falam "não, esse não é meu aluno, esse é o aluno da professora tal... eu não tenho... não sei trabalhar com ele...” e a gente não assumiu essa posição, né?! Eu sempre vou usar a gente, porque é o grupo [de professores de Ensino Fundamental II].

[...] a gente acabou assumindo uma posição realmente de... não, peraí, deixa eu tentar. Né?! Deixa eu tentar conversar com ele. Me apresenta pra ele. E ela fazia muita questão que isso acontecesse. A Ester sempre fez muita questão. Então ela chegava na sala, falava pra ele ir lá cumprimentar. Ele ia cumprimentar a gente. [...] Então, isso também foi muito importante. Isso também abriu pra gente querer: "deixa eu tentar explicar isso pra ele”. Ou alguma coisa que ela não tava conseguindo entender muito bem, ela falava: tó, explica você que você vai conseguir explicar melhor. É. E aíforam mais quatro ou três anos com ele, né, porque foi da sexta até... da quinta-sexta série até o último ano, que ele se formou, e foi um grande aprendizado pra todo mundo. Foi uma loucura.

Respeito, em um cenário inclusivo, implica no reconhecimento da diferença sem discriminar. E não discriminar, também, implica em assumir a responsabilidade, de forma coletiva. Assumir coletivamente que todo e qualquer aluno é nosso aluno ou nossa aluna, é algo que pouco a pouco vemos mais e mais educadores fazerem. Falas como "peraí, deixa eu tentar", que revelam o rompimento de uma postura passiva, que delega, para uma postura ativa, que assume a responsabilidade. E também, quando o especialista afirma "tó, explica você que você vai conseguir explicar melhor", há aí uma aposta no compartilhamento da responsabilidade. E 
isso nos remete à educação como pensada por Arendt (2011): como uma responsabilidade coletiva. Uma responsabilidade coletiva aberta para o inesperado, para a renovação: "Foi uma loucura".

Vale notarmos que o respeito, na educação, também implica em uma possibilidade de diálogo e de estabelecimento de combinados. Sobre sua experiência na rede regular de ensino, Rute nos relata:

Rute: É, eu lembro muitas vezes, por exemplo, de chegar na sala de aula, eu tinha uma sala que tinham muitos meninos, no primeiro ano de ensino médio, assim. E eram muitos meninos. E eles tavam naquela fase do truco. Aí eu entrava na sala, e aí, várias mesas assim, né?! E eu adoro jogar truco. Adoro jogar truco, né?! Eu acho muito legal. E aí, às vezes, assim, eu abria a porta e eles escondiam as cartas e ficavam né... aquela sensação, né?! Aí eu falava: "não, relaxa! Vamos! Vamos fazer assim. A gente joga hoje e amanhã eu corro com a matéria. Vocês me ajudam?” “Ajudo”. Então vamos. E era uma sala que dava problema com todos os professores! E eu conseguia dar conta do meu conteúdo tranquilamente. Porque a gente tinha esses momentos de troca. A gente tinha esses momentos de respeito. Eu acho que é principalmente isso, né?! É respeitar um ao outro. Então, por exemplo, dessa sala que tinha um monte de meninos, eu fiquei sabendo da primeira vez de muitos deles. É... quando eles tinham, é, por exemplo, eu lembro que tinha um menino que tava com medo de ter engravidado a menina, e ele veio contar pra mim. E eu acho que isso é um relacionamento íntimo, assim, né?! É uma questão de respeito mútuo, de confiança, e eu acho que isso é importante no papel do professor. Em qualquer ambiente. Se você é professor, você tem que ter isso com as crianças. E eu acho que você tem que ter isso também com a criança, é... independente de se ela é surda, surdocega, se ela é uma criança, se é um adulto. Você, enquanto professor, tem que ter esse papel, também, né?! Não é só ser obrigado a passar o conteúdo, principalmente aquele conteúdo que você não acredita muito, né, tipo, sei lá. Formação da monarquia europeia. Não. Eu não ensino a formação da monarquia europeia, cê me desculpa. Não ensino. Não vou ensinar isso. Família Tudor. Não vou ensinar. Olha, tem um seriado hoje em dia, muito legal. Assistam o seriado. Não, não acho necessário. Sabe? 
Possibilidade de renovação. O mundo para além dos conteúdos elegidos em alguns livros didáticos e em determinados currículos pré-estabelecidos - o que não implica em ignorar esse conhecimento, mas de não permanecer limitado a ele. Isso nos faz lembrar das considerações de Arendt (2011, p.247): "É muito fácil, porém, ensinar sem educar, e pode-se aprender durante o dia todo sem por isso ser educado." Ensinar conteúdos, datas, nomes... ou educar sobre o mundo, sobre pessoas, sobre acordos e sobre estar entre outras pessoas.

\subsubsection{Educação como responsabilidade}

Quando Rute começa a nos contar sobre sua experiência com Fábio, ao chegar na escola, permite pensarmos sobre o que caracteriza essa assunção coletiva da responsabilidade.

Rute: E aí, quando a gente [professores de Ensino Fundamental II] entrou, tinha um aluno, que na época tava na $6^{a}$ série, né. Antiga $\sigma^{a}$ série, que era surdocego, que era inclusive o aluno da Ester, que era o Fábio. E aí, no primeiro momento foi aquele choque, né. Que você, ai meu Deus. Como assim? Mas ele tinha toda a facilidade pela guia-intérprete dele, que é fora de série, assim, ela é fantástica. Ela tem uma troca muito grande com a gente. Ela conversa, ela pergunta, quando ela não sabe, ela não tem vergonha. Então, assim, a gente conseguiu trocar muito em relação ao Fábio. [...] Porque é assim, você fazia uma proposta de trabalho... é, dificilmente a gente diminuía ou trocava alguma coisa do currículo pra ele. Ela [Ester] conseguia fazer as adaptações, e a gente pensava muito junto, né. Então, por exemplo, é... sei lá. Eu lembro que a gente estava falando sobre a Independência dos Estados Unidos, então eu falava pra ela, o que que é importante ele saber, desses conceitos? Como que é mais fácil? Então, todo o texto que era dado para os alunos, pra ele era dado em braile. Ele que fazia em braile enquanto que os alunos estavam copiando. As imagens, ela adaptava todos em... no tátil, pra ele. Mapa, é... se tivesse alguma imagem de pessoa, ela dava um jeito de tentar adaptar. Então era muito gostoso o trabalho.

Assumir a responsabilidade como uma pessoa adulta, representante deste mundo. "Mas ele tinha toda a facilidade pela guia-intérprete dele”, e é a essa guia-intérprete que essa professora, e todos os demais, se juntam. E o convívio em sociedade não seria isso? A troca? O 
estar entre? A presença do outro com quem posso compor e buscar soluções para as questões que se apresentam?

E quando Ester nos conta sobre a chegada de Fábio em sua sala, suas palavras retratam como essa assunção se deu desde o início.

Ester: Eu era a professora da sala. Regência. E a Luciana, ficaria com ele. Como se fosse guia-intérprete, né?! [...] mas eu falei com a Luciana o seguinte. Luciana... ela ficaria o tempo todo com ele. Mas como ela também é professora, eu falei. Vamos fazer o seguinte? Vamos combinar entre nós e fazer assim: uma semana, eu fico com o Fábio, dentro da sala, e uma semana você fica com a sala. E a outra semana, a gente trocava. Por quê? Porque pra ter contato com o Fábio, direto. Porque eu como regente da sala não teria contato diretamente com ele. Quer dizer, de estar ali todo o dia, de aprender, de como fazer. Eu estava vendo. Lógico, ele sabia. Mas... ter o contato. Como eu queria ter esse contato, então a gente trocava. Então, era muito legal, porque assim, uma semana... nesta semana eu tava com a regência da sala. Dando as aulas, e tal, tal, tal. Ela seguia meu plano lá. Na outra semana, ela ficava na regência e eu ficava com ele. Então ele tinha minha presença ali, sempre junto. Professora e guiaintérprete. Sempre junto. Muito perto.

E assim como Rute exemplifica em sua fala, Ester também reforça a questão do respeito ao assumir que o aluno era parte de sua sala. Por isso, “ter contato com o Fábio, direto." Sem delegar a um especialista ou à guia-intérprete. Assunção coletiva da responsabilidade: "Professora e guia-intérprete. Sempre junto. Muito perto."

Mesmo as demais educadoras que não se envolveram diretamente, assumiram essa responsabilidade coletiva. Isto porque, apesar das dissensões presentes na unidade educacional, como em qualquer outro espaço coletivo, é possível perceber que a comunidade escolar organizou-se para que, desde o início, a professora em módulo acompanhasse essa sala, o que não é pouco. Quem conhece a dinâmica das escolas públicas e da organização da rotina dos professores em módulo, certamente consegue vislumbrar as possíveis barreiras que poderiam ter sido geradas pelas outras professoras.

Tendo garantido o direito de estar na escola, com a matrícula; tendo sido acolhido pelas pessoas, por meio das ações coletivas; tendo sido respeitado em sua singularidade: vimos aí um cenário inclusivo para Fábio, onde a educação encontrou "uma época de esclarecimento", como 
afirma Adorno ao recuperar a resposta de Kant, para quem o esclarecimento e a consequente emancipação, não remetem a algo estático, e sim "como um vir-a-ser", como uma possibilidade (ADORNO, 2012, p.181).

Assumir a responsabilidade, de forma coletiva, é superar uma função ou um papel. É ser adulto e não apenas representar ser um adulto (ADORNO, 2012, p.178-179) e isso exige dinamismo, flexibilidade e abertura para a mudança. Não basta seguir um roteiro pré-estabelecido e fazer o que esperam que se faça, ser um exemplo de conduta, como se acreditava na essência da atitude romana (ARENDT, 2011, p.244). E também não se trata de inventar tecnologias mirabolantes nem de investir milhões. Como Arendt (2011, p.247) propõe, diz respeito à "nossa atitude face ao fato da natalidade: o fato de todos nós virmos ao mundo ao nascermos e de ser o mundo constantemente renovado mediante o nascimento." É a possibilidade de renovação, que ocorre apenas enquanto sociedades de seres humanos, vivos, entre os homens (Arendt, 2010, p.9). E é nessa condição, entre outros adultos, em uma pluralidade de seres únicos em ação (Arendt, 2010, p.220) que a possibilidade da emancipação se evidencia. Quando um conjunto de pessoas adultas assumem, coletivamente, a responsabilidade de apresentar o mundo a toda e qualquer criança, há aí um "vir-a-ser" possível. E o "vir-a-ser" não tem relação com o que se fala sobre sucesso ou fracasso escolar, porque ele é dinâmico, e não tem um ponto final, pois deve manter o caráter processual.

Portanto, no momento em que a inclusão é compreendida para além de qualquer "fim", para além do "para quê?", pode ser colocada lado a lado com a emancipação, e deixa de ser uma alternativa à ela. E ainda, poderíamos pensar em uma inversão com o uso de uma conjunção conclusiva: inclusão, logo emancipação.

\subsection{O BILINGUISMO COMO MODELO INCLUSIVO}

Tendo compreendido a importância do papel dessas pessoas adultas envolvidas na educação dos alunos com surdocegueira, importa perguntarmos: o que é uma escola bilíngue e, mais especificamente, o que são as EMEBS da RME de São Paulo?

No capítulo intitulado "A Educação de Pessoas com Surdocegueira”, apresentamos informações mais gerais sobre os projetos, a legislação e alguns aspectos históricos para situarmos esse cenário. Aqui, resgatamos trechos das falas das colaboradoras que nos permitiram pensar sobre o significado da transformação de EMEE para EMEBS e como este espaço acolhe os alunos com surdocegueira. Essas falas nos forneceram dados para a compreensão da complexidade desse espaço. 
Antes de qualquer questão, é importante notarmos que a mudança maior está no reconhecimento da Libras, que já havia sido oficializada em 2002, pela Lei ${ }^{\circ} 10.436$. O decreto $\mathrm{n}^{\circ}$ 52.785, de 10 de novembro de 2011, que cria as EMEBS apenas reconheceu algo que historicamente já estava presente. E é interessante perceber como as narrativas que reproduzem uma trajetória linear histórica positivista, do oralismo ao bilinguismo, introduz muitas falas. A título de exemplo, escolhemos um trecho da entrevista de Ester:

Ester: Eu acho que é assim: foram momentos de fase, né. Fases da educação. Então... antigamente que era o Oralismo, Comunicação Total, tal, foi caindo... aí veio o bilinguismo.

Lia: Português sinalizado...

Ester: Português sinalizado, isso foram as épocas. O que aconteceu na escola, porque todo mundo acreditava naquilo, lógico, né?! Tudo que acontece, você acredita naquilo, até que mude ou que você veja que teve uma mudança mesmo, né?! Como aconteceu com a Libras.

Porém, a continuação de sua fala, com exemplos e argumentações, evidencia sua consciência sobre a complexidade da questão, livre desse discurso linear:

Ester: Então, mas... a todo tempo, estava sempre presente. A língua [Libras], aí, na escola. Sempre tava presente, sempre, não sei, assim, com vários nomes que eu te falei antes, linguagem de sinais, uma coisa errada, antes, mas era o que se tinha na época, anteriormente, e depois com os estudos e tudo, com as pesquisas, eu acho assim, eu acho que veio ter mais força, na verdade. Mas dentro de uma EMEBS, já existia, essa língua. Sempre existiu, né?! Não assim, talvez, tão divulgada. Não é tão divulgada... como posso dizer, é... tão estudada, mas já existia, porque surdo sempre fez sinais. Sempre fez, a língua. Sempre teve a língua, os surdos daí, né?! Mesmo os antigos, sempre tiveram. Alguns foram banidos, porque não podia fazer, na época, não podia. Que nem o Luís fala que ele não podia fazer, mas sempre existiu, quer dizer, sempre teve a Libras, sempre teve a língua. Só que aí, eu acho que a questão da educação bilíngue, o que vem reforçar, é realmente essa questão da língua mesmo. Libras como língua.

Lia: De uma forma oficial. 
Ester: Oficial e não Libras como sinal, como gesto, como qualquer coisa de apontar. Não. Como língua. Como eu te falei, assim, os estudos, mostrando que tem uma gramática, que é uma língua, igual qualquer outra. Só que ela muda porque é gestual-visual... só, mas ela é língua.

Isto é, de um “antigamente era", temos um "sempre existiu”, e apesar de iniciar falando sobre fases, ao final, ela conclui:

Ester: Na verdade eu acho que... veio só reforçar, né, e reforçar pra dizer que é uma língua, reconhecimento, eu acho que os próprios alunos também não tinham essa ideia.

A partir dessas reflexões, Ester mostra a importância da escola como um espaço de formação de cidadãos como trazido a seguir. São as professoras que, inicialmente, recebem a formação e passam a ter contato com as discussões teóricas, muitas delas estabelecidas com Surdos adultos - e foi possível notar um florescimento dessas discussões, na última década, tanto nas universidades como em espaços políticos como Conselhos Municipais, Câmara Municipal, entre outros. Quando se trata de Surdos, filhos de pais ouvintes, muitas vezes é a escola que estabelece esse vínculo com a Comunidade Surda e com a Cultura Surda. Isso também fica evidente quando Ester afirma:

Ester: Quando eu fiz a pós de Surdos, eu cheguei a dar aula de Libras, aí na escola mesmo, pro oitavo ano, já começava a colocá-los nessa questão da língua, de estudo mesmo. A falar: "olha, a língua é de vocês". Mas eles não tinham esse conhecimento. Não tem mesmo. Então eu acho que é o momento também da gente estudar com eles a língua, como essa língua se formou. Assim, desse jeito. Não só os parâmetros, que é coisa comum. Que isso se estuda. Ah... eles sabem, também. Mas assim, algo de que, é... estabelecer com eles, que realmente eles têm que adquirir, que é uma língua deles. Que é a língua mesmo oficial, como outra qualquer. Como o inglês, que tem essa validade. Que eles têm que saber entender. Então esses processos que eu estou estudando na Libras, que eu falei que eu utilizo, a interpretação, como isso ocorre, eu passava isso pra eles, algumas coisas, eu passava pros alunos maiores. Eles diziam: "puxa, é verdade, é assim que se faz". Mas eles não sabiam. Não tinham o nome, né?! Mas era 
legal, porque já são mais adultos, né?! Pra eles entenderem. Pra terem essa consciência maior. Sabe?! Queria estudar mais sobre a língua mesmo deles, né?! Como que surge... surge, é, fez a lei. Mas não é só por isso que eu tenho direito. Não. Eu tenho meus direitos, mas o que que é essa língua pra mim. $O$ que que eu... por que que o pessoal, por que as pessoas estudam, porque não adianta só eu estudar sobre isso, né?! Eu não sou Surda, mas também fui estudar sobre a língua, pra conhecer. Aí eles ficavam curiosos, eu comparava com eles, algum processo acontecia. Eu falava: “olha, isso não acontece?” "Ah! É verdade!" Aí eles começavam a pensar sobre essa questão da língua. Não era só passar a Libras por Libras, porque Libras por Libras, eles são, eles entendem...

A escola como um espaço onde adultos, que já se apropriaram das discussões teóricas e políticas, podem compor com os alunos um lugar público, como compreendido pelos gregos, para quem "o domínio público era reservado à individualidade; era o único lugar em que os homens podiam mostrar quem realmente eram e o quanto eram insubstituíveis" (ARENDT, 2010, p.50). Mais do que isso, a importância de estarem na escola professores, educadores, adultos suficientemente humildes para reconhecer que há tanto a aprender quanto a ensinar: “porque Libras por Libras, eles são, eles entendem”. E voltamos à questão do professor como alguém que, por já estar neste mundo há mais tempo, apresenta o mesmo para as crianças, sem deixar de estar aberto para "a renovação e a vinda dos novos e dos jovens" (ARENDT, 2011, p.247).

Rute também nos mostra como a sua chegada na EMEBS implicou em assumir o papel de aprendiz, de se ver frente a um cenário cultural novo, onde ela tinha muito a estudar. Principalmente no que diz respeito à Libras, pois mesmo tendo cursado a especialização em um contexto onde a Libras já era reconhecida como língua, esse curso, na área de surdez, realizado em parceria com a Prefeitura Municipal de São Paulo em 2011, ainda era "muito oralista, muitas questões técnicas”, segundo sua percepção atual. Já o outro curso de especialização realizado mais recentemente, em 2014, também em parceria com a Prefeitura, "teve uma outra linha. Já teve uma outra visão".

Não se trata de categorizar instituições ou afirmar que um modelo é mais "avançado" do que o outro, mas de compreender como os diferentes modelos, formas de atuação e até intervenção, seja na área da saúde como da educação, estão presentes, concomitantemente. Mudanças, transformações, adultos dispostos a aceitar a renovação e assim, voltarem a ser alunos. E as transformações, hoje, implicam em aceitar a pluralidade. 
Rute: É... dentro da escola em si, você tem, como em qualquer outra escola, né, em qualquer outro lugar, você tem uma mistura. Cê tem professores... é... que são bilíngues e se entendem enquanto bilíngues, e tem a prática bilíngue. Você tem professores que se dizem bilíngues, mas não tem a prática. Quando você vai pra prática, você vê que falta. É. E você tem alguns que ainda, você passa pelo corredor e você fala: "esse é oralista”. Fala, grita, né... e aí, você fica meio assim. Então, dentro da escola mesmo, você tem de tudo. Não dá pra falar que a escola segue uma linha.

E a questão: trata-se de um período de transição? Ou o que significa a presença de professores oralistas em uma escola bilíngue? Não será possível responder a estas questões, mas acreditamos que antes de qualquer aspecto, consideramos essencial que os adultos tenham clareza do próprio posicionamento político e teórico, com argumentos que não se restrinjam a "tendências" ou "modismos", para poder permitir que os novos e os jovens componham um corpo político. Um corpo político que tenha clareza dessa pluralidade e, assim, seja capaz de respeitar a diferença. Isso é tão relevante quanto ter consciência do direito à formação de uma identidade social. Esta deve, na grande maioria das vezes, ser conquistada e construída, e é algo singular. Identidade social não se refere apenas à classe, mas também ao como eu me vejo e como quero ser visto. Uma pessoa com perda auditiva? Uma pessoa Surda? E não apenas isso: uma mulher, negra, Surda, estudante universitária, paulistana, casada, sem filhos, que mora na Zona Norte, que gosta de dançar, que... que... É dessa construção identitária complexa e diversa, que estamos falando. Uma construção que deve superar os estigmas e a linguagem dos opressores $^{72}$. E isso só é possível em um espaço que respeite e compreenda tanto a diversidade como a pluralidade.

Essa reflexão deriva das discussões de Arendt sobre o agente no discurso e na ação:

A pluralidade humana, condição básica da ação e do discurso, tem o duplo aspecto da igualdade e da distinção. Se não fossem iguais, os homens não poderiam compreender uns aos outros e os que vieram antes deles, nem fazer planos para o futuro, nem prever as necessidades daqueles que virão depois deles. Se não fossem distintos, sendo cada

\footnotetext{
${ }^{72}$ Não podemos deixar de dar crédito a Diran e Janaína, colegas educadores com quem tive o privilégio de trabalhar durante a $32^{\mathrm{a}}$ Bienal de São Paulo, que em rodas de conversa, ao versarem sobre a questão de gênero e a questão racial, fizeram com que pudéssemos compreender todas as violências implícitas nas relações humanas mais cotidianas. Quando pensamos sobre identidade e violência, trazemos reflexões herdadas de suas palavras.

E sobre a necessidade de se libertar da linguagem do outro, é necessário ouvir Grada Kilomba em "Lidando com o racismo na Europa". Disponível em: https://www.youtube.com/watch?v=DdpUFybJddc. Acesso em: 10 jun. 2016.
} 
ser humano distinto de qualquer outro que é, foi ou será, não precisariam do discurso nem da ação para se fazerem compreender. [...] No homem, a alteridade, que ele partilha com tudo o que existe, e a distinção, que ele partilha com tudo o que vive, tornamse unicidade, e a pluralidade humana é a paradoxal pluralidade de seres únicos. (ARENDT, 2010, p.219-220)

Pluralidade de seres únicos em uma sociedade que deve ser marcada pela diversidade: ricos, pobres, bilíngues, oralizados, com traços orientais, negros, brancos, imigrantes, cisgêneros, transgêneros, bissexuais, heterossexuais, homossexuais, ouvintes que perderam a audição, Surdos congênitos, filhos de Surdos, filhos de ouvintes, filhos de ouvintes que não falam português, pessoas com deficiência múltipla, com surdocegueira, com cabelos loiros, com cabelos escuros, amantes de literatura, apaixonados por dança... todos devem ter assegurado o acesso à escola pública. E não estaremos sendo repetitivos ao lembrar: inclusão deve implicar em direito, acolhimento, respeito e responsabilidade coletiva.

Pensar a pluralidade, para nós, herdeiros desse grande monumento invisível, exige esforço, porque vai além da diversidade e das caracterizações, e traz a unicidade. E o questionamento e a reflexão tornam-se necessidades constantes para essa grande "unidade da coletividade manipulada" onde não há indivíduos e sim seres iguais, pois "consiste na negação de cada indivíduo" (ADORNO; HORKHEIMER, 1985, p.24). E é essa crença na igualdade que, possivelmente, nos leva a buscar receitas, modelos prévios e soluções prontas.

Rute: Então, isso, por exemplo, sempre foi uma grande briga minha, desde que eu entrei. Desde que eu comecei a estudar sobre surdocegueira, isso sempre foi uma briga. A gente recebeu uma aluna na sétima série, na antiga sétima série, que ela falava, ela ouvia com ajuda do aparelho, ela ouvia super bem, e ela teve glaucoma, então ela perdeu, sei lá, $80 \%$ da visão muito rápido. E ela tinha menos... ela tinha o quê, 11 anos. E aí, [...] ah! Usa aparelho, é surda. Perdeu a visão, é cega. Surdocega, manda pro [nome da EMEBS]. E aí, ficou naquela posição, né. Ela ouve, ela não sabe Libras, porque ela ouve, porque ela fala, se comunica através da fala. É... ela não enxerga o suficiente para ver a Libras na frente, né, então o professor sinalizando não é o suficiente, mas como ela ouve não era vista como surdocega. Aí ela ficou três, quatro anos na escola, sem apoio, sem um guia-intérprete, e a gente tendo que se virar enquanto professor, né. 
Mais uma vez, o coletivo de profissionais, professores adultos, buscaram uma solução possível para aquele momento:

Rute: Então a gente colocou ela junto com o Fábio e a Ester. Ela se formou junto com o Fábio, pra ver se a Ester conseguia auxiliar um pouco ela, mas, né, levando em consideração que a Ester era guia-intérprete do Fábio, ela tinha que dar muito mais atenção pro Fábio.

E a ação não deve se restringir apenas à escola. A necessidade da formação de redes de proteção para assegurar os direitos de todas as crianças e adolescentes é inquestionável. Afinal de contas, educação é processo contínuo e não se restringe a cinco horas diárias, de segunda a sexta, com direito a férias escolares. Escolarização, sim. Tem hora e lugar - ao menos em alguns modelos atuais.

Rute: É... o que a gente fez junto com o [nome de instituição], que ela frequentava, foi fortalecer o braile. Né, então, a gente, eu, pelo menos, insisti muito pra que ela treinasse braile, né, já que ela tava ali, a gente tinha máquina. A gente tinha tudo aquilo porque o Fábio também usava. Então a gente insistiu muito pra que ela usasse o braile.

E vale insistirmos na ideia da responsabilidade coletiva. E mesmo assim, apesar de todas as ações, a insatisfação e os questionamentos da professora perduram.

Rute: mas assim, é... o problema foi essa questão de entendimento de surdocego, né. Entendimento da surdocegueira e as diferentes variações, que não teve essa compreensão dentro da escola. E aí, eu falo dentro da escola, porque não chegou nem a ser um problema levado pra fora. Que dentro da escola resolveu-se que não... que não era necessário [um guia-intérprete].

Uma professora que percebia a pluralidade entre os alunos com surdocegueira e a singularidade dessa aluna dentro de uma escola bilíngue, e que compreendia que, antes de mais nada, deveria ser uma escola para pessoas. Dessa forma, Rute nos faz pensar como é importante formular políticas públicas que não ignorem a diversidade. Sem isso, o respeito à diferença corre riscos. Sem isso, a possibilidade de surgirem novas respostas corre riscos. Sem isso, a 
educação bilíngue corre riscos. Afinal de contas, quando perdura a escolha pela não diversidade e pela imposição de uma resposta única, há violência. E violência, ou brutalidade, como nos lembra Adorno (1995, p.166), é a perpetuação da barbárie.

Quando houve a mudança legal de EMEE para EMEBS, o direito à identidade Surda foi reconhecido, e uma violência sutil - mas não menos agressiva, apesar da sutileza - deixa de ser cometida: paramos de colocar esse outro em um lugar "especial".

Sara: E nesse meio todo teve também a transformação de EMEE em EMEBS, que era Escola Municipal de Educação Especial em Escola Municipal de Educação Bilíngue, que trouxe pro aluno também, ah... é incrível, sabe, Lia... receber o diploma de uma Escola Bilíngue, pra ele era diferente de receber um diploma de uma Escola Especial. Quando ele recebia o... ele, ele... gostava, sem dúvida, de ser formado pela EMEE e tal, mas a Escola Bilíngue, trouxe um status pro aluno, muito mais, assim, muito maior. Então ele, o orgulho, sabe, de ser aluno de uma escola bilíngue era diferente. Esse Escola Especial, talvez, trouxesse um pouco de... demérito, vamos dizer assim, pro aluno, sabe?!

É, “ele...gostava, sem dúvida, de ser formado pela EMEE e tal, mas a Escola Bilíngue”, mas a Escola Bilíngue, que deixa os estigmas, que não mais aponta para ele como "especial", que aceita sua singularidade.

E quando afirmamos que a educação bilíngue corre riscos, nos lembramos dos períodos pós I e II Grandes Guerras, quando o desenvolvimento científico fez com que as pessoas apostassem mais e mais na "cura", com os aparelhos auditivos e novas técnicas de oralização.

Os avanços biotecnológicos atuais, cada vez mais rápidos, superestimam as possibilidades da ciência e vão em direção a um discurso preso à ideia da adequação à norma. E quando a crença em uma resposta única prevalece, o respeito à diferença se perde, e em um cenário assim, a educação bilíngue corre riscos. Basta a chegada de mais uma invenção para que os pais passem a ser, outra vez, tentados a oferecer "o melhor" para seus filhos - um "melhor" que é norma, um “melhor” que é padrão, majoritário, ouvinte.

As discussões em torno do implante coclear dão uma pista sobre esse risco. E o mais difícil é enxergar a violência por trás de tanto amor. Como questionar ou criticar um adulto ouvinte que busca o "melhor", de acordo com as informações que possui, de acordo com a sua visão de mundo, para seu filho ou para sua filha com deficiência auditiva? 
Portanto, todos os pais ou responsáveis deveriam ser plenamente informados sobre as diversas possibilidades em termos de metodologias de ensino e terapêuticos, para serem capazes de compreender que elas não são necessariamente excludentes. E todas as crianças e adolescentes deveriam ter direito ao acesso a essas possibilidades. Talvez, se essa aluna de que nos falou Rute, e sua família, tivessem recebido mais informações, não optassem por uma EMEBS. Isso porque ela não tinha uma identidade surda, e sim ouvinte.

Quando a EMEBS foi indicada para essa aluna, o critério foi o da perda auditiva associada à perda visual. O critério para a indicação da EMEBS, por sua vez, deve ser cultural e linguístico. Isso mostra como, mesmo com a mudança do nome, e mesmo com a legislação, de alguma forma, algo da mentalidade da escola especial perdura.

A questão central, quando quebramos o discurso sobre uma suposta linearidade histórica dos métodos educacionais para Surdos, é a importância de se compreender a surdez como uma marca identitária que deve ser respeitada. Não se trata de buscar o melhor método de ensino, nem a abordagem mais eficaz. Há muitos Surdos, que se identificam como Surdos, que sabem Libras, que lutaram pelo reconhecimento da Libras, sujeitos adultos com forte atuação política, e que foram formados nas escolas Oralistas ou em instituições que seguiam a Comunicação Total. Uma prova de que esses métodos ou abordagens, nas mãos de professores comprometidos, podem dar certo. Mas não é esta a questão. A Escola Bilíngue para Surdos e a Libras são um direito cultural. Não se questiona se a terapia fonoaudiológica é boa ou ruim, porque não estamos falando de cura. Não se trata de método ou abordagem de ensino, porque não estamos falando de didática ou de formação de professores.

A EMEBS representa uma junção do direito político da igualdade, com o direito social da discriminação (ARENDT, 2004, p.274), tendo como alicerce os direitos humanos. E deve ficar clara a importância da identidade institucional: é Escola Municipal de Educação Bilíngue para Surdos, e não mais escola especial.

Lídia: Eu acho que essa escola municipal especial, ela era muito ampla, né. Não dizia muita coisa. Eu acho que ela, quando vai pra EMEBS, passa não só a questão do nome, mas de... fortalecer e de dar a devida importância a uma escola para o Surdo. Né?! Que eles são alunos bilíngues, né?! [...] E também, junto com isso, vem a questão do que a gente ganhou. Não só da troca do nome, mas em termos de instrutor, de guia-intérprete, da entrada dos múltiplos, acho que ganha em muitos aspectos. Acho que essa passagem foi muito importante, 
de valorização, de luta pela escola bilíngue, de luta pelo Surdo, que eu acho que é uma luta que vai ter que ser pra sempre [...]

Uma identidade que trouxe ganhos. Não só a troca do nome, mas a ampliação dos recursos humanos, com outros adultos que passaram a compor esse coletivo de profissionais da educação, esse coletivo de educadores: instrutores, guias-intérpretes, além dos já presentes AVE, "uma luta que vai ter que ser pra sempre”. E desse coletivo de educadores, é necessário destacar a importância dos instrutores Surdos, e a importância de sua presença ali, com diferentes histórias de vida, com percursos únicos, com sua singularidade.

Sara: Ah! E com a chegada do decreto que cria as EMEBS, ele é m... inovador. Inovador demais. E foi assim, feito um material também de apoio, naqueles cadernos de apoio em Libras, que foi super importante também para a escola. Apesar do aluno surdocego não se beneficiar desse material, ele, ah... foi um material que engrandeceu a Libras. E eu entendo que se a Libras está como primeira língua dentro da escola e com um status, naquele momento, superior ao da língua portuguesa oral, ele, o... de certa forma, a Libras tátil entra nesse meio, né?! Ela... Se você, se a Libras é elevada, a Libras tátil vai junto, né, não tem como ficar... e, as sessões pipoca que a gente fez junto com a Mariana, que trazia as lideranças [...], lá na escola. Os alunos, né, tinham a oportunidade de conhecer os surdocegos adultos e autônomos, então, foi assim, um momento, muito muito legal na escola.

Adultos com uma vida ativa e independente. De um lado, lideranças com surdocegueira apresentando formas de comunicação próprias, trazendo suas experiências e cumprindo todos os requisitos apontados por Arendt (2011): assumindo a responsabilidade por este mundo, introduzindo os jovens no mundo, e assim, adultos educadores. De outro, profissionais da educação, em SME, elaborando materiais de apoio em Libras. Formações específicas com especialistas em Libras, tanto para a equipe gestora, em SME, como para os professores que cumprem Jornada Especial Integral de Formação $(\mathrm{JEIF})^{73}$, em horário coletivo. Mas a complexidade da questão não se encerra aí. A luta não se encerra aí.

\footnotetext{
${ }^{73}$ Segundo $\$ 4^{\circ}$ do Artigo $2^{\circ}$ da Portaria 647 de 24 de janeiro de 2008, “A Jornada Especial Integral de Formação - JEIF corresponde a 40 (quarenta) horas-aula semanais, sendo 25 (vinte e cinco) horas-aula de regência e 15
} 


\subsubsection{A igualdade na pluralidade}

A luta não se encerra aí. Por mais que se pense em garantir direitos iguais, é difícil de aceitar efetiva e plenamente a pluralidade. Garantia de direitos e homogeneização, não raras vezes, acabam por se confundir. É como se a garantia de direitos implicasse em tornar todos os mais iguais possível. Quanto mais semelhantes, menos é necessário fazer - ou ao menos é essa a impressão que se tem. Isso funcionava muito bem quando os direitos eram privilégios de pessoas muito semelhantes. Atualmente, após inúmeras lutas de tantos coletivos para o reconhecimento de seus direitos a serem diferentes, essa homogeneização já não é mais possível. E é onde se estabelece uma das mais recentes lutas dos Surdos, que percebemos como nossos próprios pensamentos ainda estavam contaminados pela normatividade: a extensão do ensino bilíngue das EMEBS, que abrangem apenas o Ensino Fundamental I e II, para o Ensino Médio.

Lídia: [...] agora, uma outra luta que eles tão travando é a questão do... do Ensino Médio, mas que é muito difícil, porque hoje também... eu vejo assim, eu acho que eles poderiam, a escola bilíngue, acho que ela garante a... bacana, pra eles, né, essa questão da... do ensino formal. Só que acho que dá uma isolada. O ideal seria a gente ter uma escola dessa garantida, mas eles também estarem próximos dos ouvintes. Eu acho que... mas não é possível. Mas seria, vai, a Escola Pólo. Acho que a ideia da Escola Pólo [...]

E o que é a escola pólo? Uma escola regular, com uma maioria ouvinte, mas que concentra um número considerável de alunos Surdos. Essa escola assegura intérpretes de Libras em sala de aula, onde os professores ouvintes dão aulas em português oral. E conta também com instrutores de Libras, muitas vezes $\operatorname{Surdos}^{74}$.

(quinze) horas adicionais; destas, 11 (onze) a serem cumpridas obrigatoriamente na escola e 04 (quatro) em local de livre escolha." As formações aconteciam na escola, em parte dessas onze horas cumpridas na unidade.

${ }^{74}$ Segundo artigo publicado no portal da Prefeitura de São Paulo, sobre as Unidades Pólo, o atendimento ocorre nas classes bilíngues, denominadas Salas de Apoio e Acompanhamento à Inclusão - SAAI Bilíngue, com professores especializados.

Na Educação Infantil, no Ciclo de Alfabetização e no $4^{\circ}$ e $5^{\circ}$ ano do Ciclo Interdisciplinar o atendimento é exclusivo na SAAI Bilíngue I, sendo o trabalho com as áreas de conhecimento realizado em LIBRAS como primeira língua e o ensino de língua portuguesa, na modalidade escrita, como segunda língua.

No $6^{\circ}$ ano do Ciclo Interdisciplinar e no Ciclo Autoral, a SAAI Bilíngue II trabalha com os educandos surdos matriculados nas classes comuns e a disciplina de Língua Portuguesa é ministrada com metodologia de ensino de segunda língua. [grifo nosso] 
Ao iniciarmos este estudo, e mesmo quando as entrevistas foram realizadas, concordávamos com essa colocação que surgiu não apenas na fala da Lídia, mas que é frequente entre educadores ouvintes que atuam com surdos. Isso porque, como ouvintes, algumas questões nos vêm automaticamente à cabeça: Como eles vão se preparar para o mundo? Para o mercado de trabalho? Precisam aprender a se virar sozinhos.

Porém, ao final de um o percurso de três anos de pesquisa, a reflexão contínua sobre a questão da pluralidade, paralelamente à leitura de estudos teóricos, fez com que mudássemos nossa compreensão sobre o que é a Escola Bilíngue e por que ela poderia, sim, abarcar o ensino médio e, também, a universidade. Basta trazermos o exemplo da Gallaudet University, que já em 1864 passou a conferir diplomas de grau superior - college degrees - e recebe o status de universidade, pelo Congresso dos Estados Unidos, em $1986 .^{75}$

E o que nos fez mudar o posicionamento? Em Reflexões sobre Little Rock (ARENDT, 2004, p.226), há uma discussão que nos parece extremamente pertinente sobre a segregação. Ao analisar a famosa foto de uma aluna negra passando em meio a colegas brancos lançandolhe impropérios, a autora questiona: “o que eu faria, se fosse uma mãe negra?” E a sua resposta, é, no mínimo, provocativa:

[...] em nenhuma circunstância exporia meu filho a condições que dariam a impressão de querer forçar a sua entrada num grupo em que não era desejado. Psicologicamente, a situação de não ser desejado (uma situação embaraçosa tipicamente social) é mais difícil de suportar do que a franca perseguição (uma situação política embaraçosa) porque o orgulho pessoal está envolvido.

Não é difícil estabelecer um paralelo com a fala de muitos familiares de alunos com deficiência sendo incluídos na rede regular de ensino. Mas é necessário cuidado. O mais importante na sua reflexão são as pistas para uma ampliação da compreensão da importância das escolas bilíngues para Surdos e não da segregação de escolas especiais. Arendt (2004, p.272) caracteriza a igualdade como um direito nascido e válido na esfera política:

\begin{abstract}
A segregação é a discriminação imposta pela lei, e a dessegregação não pode fazer mais do que abolir a discriminação e forçar a igualdade sobre a sociedade, mas pode e na verdade deve impor a igualdade dentro do corpo político. Pois a igualdade não só tem sua origem no corpo político; a sua validade é claramente restrita à esfera política. Apenas nesse âmbito somos todos iguais. [grifo nosso]
\end{abstract}

Apenas no âmbito político somos todos iguais. Não se trata da crença em uma suposta verdade universal. Pelo contrário! Arendt defende a discriminação como um direito social e

Disponível em: <http://portalsme.prefeitura.sp.gov.br/Main/Page/PortalSMESP/Educacao-Bilingue-para-Surdos>. Último acesso em 15 dez. 2016. Uma avaliação detalhada dessas unidades também permite um rico objeto de estudo.

${ }^{75}$ Conforme histórico disponível em: <http://www.gallaudet.edu/history.html>. Último acesso em 08 dez. 2016. 
alerta para o perigo do conformismo quando este busca a mera similitude. Afinal de contas, para sermos aceitos em qualquer sociedade, conformar-se e ser como os outros é, ou pelo menos foi, por muito tempo, uma necessidade. O perigo reside em uma eventual transformação desse conformismo social em "um valor absoluto e um substituto para a homogeneidade nacional" (ARENDT, 2004, p.274).

Ao reunir a questão da igualdade e da discriminação, suas palavras são esclarecedoras:

[...] a discriminação é um direito social tão indispensável quanto a igualdade é um direito político. A questão não é como abolir a discriminação, mas como mantê-la confinada dentro da esfera social, quando é legítima, e impedir que passe para a esfera política e pessoal, quando é destrutiva. (Arendt, 2004, p.274)

E é importante lembrar que a autora já havia destacado previamente o fato dos direitos políticos serem secundários frente aos direitos humanos (ARENDT, 2004, p.271).

Podemos retomar, ainda, suas considerações sobre a pluralidade humana. Parece-nos claro que a igualdade política não pode deixar de considerar a pluralidade e o direito à distinção. Estes permitem que se respeite a unicidade de cada indivíduo e o valor do mesmo em sua singularidade, e não importa se esse respeito resulte em uma suposta redução da felicidade da comunidade ${ }^{76}$.

\begin{abstract}
A distinção humana não é idêntica à alteridade - à curiosa qualidade de alteritas, comum a tudo o que existe e que, por conseguinte, para a filosofia medieval, é uma das quatro características básicas e universais do Ser, transcendendo toda qualidade particular. A alteridade é, sem dúvida, aspecto importante da pluralidade, a razão pela qual todas as nossas definições são distinções, pela qual não podemos dizer o que uma coisa é sem distingui-la de outra. Em sua forma mais abstrata, a alteridade está presente somente na mera multiplicação de objetos inorgânicos, ao passo que toda vida orgânica já exibe variações e distinções, inclusive entre indivíduos da mesma espécie. Só o homem, porém, é capaz de exprimir essa distinção e distinguir-se, e só ele é capaz de comunicar a si próprio e não apenas comunicar alguma coisa - como sede, fome, afeto, hostilidade ou medo. (ARENDT, 2010, p.219-220)
\end{abstract}

Não apenas ser distinguido, ser apontado como ou definido como, mas distinguir-se. E essa distinção também está presente em Adorno e Horkheimer (1985, p.156), quando esses autores pensam sobre a diferenciação, possível apenas com o pensamento. Ser capaz de assumir e exprimir o lugar escolhido, sabendo que este é singular e não precisa, necessariamente, se assemelhar aos outros lugares. E quando chega um aluno com surdocegueira na EMEBS - por conta da questão linguística e do apoio constante e direto da instituição especializada de origem, conveniada à $\mathrm{RME}$-, é aí que ele encontra o direito de manter sua singularidade, estando entre

\footnotetext{
${ }^{76}$ O conto de Ursula le Guin, "The ones who walk away from Omelas" pode ser uma boa leitura introdutória para se pensar essa questão.
} 
outros. Vale informar que, mais do que o conhecimento especializado, a importância dessa parceria da instituição especializada estava no compartilhamento da responsabilidade. Isto porque, se era algo novo, ninguém sabia como fazer. Se cada aluno com surdocegueira tem especificidades únicas, não há possibilidade de se criar "receitas" de sucesso. Essa importância da escolha da EMEBS fica mais clara na fala de Sara:

Lia: A Mariana não cogitou nenhuma escola regular?

Sara: Não. Não. E a Mariana, acho que nem gostaria que fosse uma escola regular, porque o pré conhecimento do professor em Libras, iria fazer toda a diferença no acolhimento do aluno pra Libras tátil. Então, acho que, ele talvez ficasse isolado, numa escola. E o que, a surpresa também que a gente teve que foi assim... muito legal, quando o Fábio entrou, é que três, quatro alunos, da EMEE, na época, imediatamente, assim... instintivamente, começaram a conversar em Libras tátil com o Fábio.

Lia: Nossa.

Sara: Então, até... um dos meninos, funcionava até meio como um tradutor pro Fábio nos momentos de recreação, de lanche, etc. Ele ficava passando informações através da Libras tátil, mas nunca apren[deu]... ele viu a professora, né, e...

Lia: Naturalmente...

Sara: Naturalmente. E aí, o fato do Fábio conversar com outros alunos, em Libras tátil, eu acho que também foi muito bom pro desenvolvimento dele. Coisa que numa escola comum ele não iria ter. Porque na escola comum, os amiguinhos não sabem Libras. Ainda que ele tivesse um guia, numa escola comum, a comunicação com os amiguinhos seria bem mais complexa.

Lia: A questão dos pares, né?!

Sara: Na questão de... dos meninos não conhecerem Libras. Porque, por exemplo, a inclusão de um aluno Surdo, o menino começa, o coleguinha começa a aprender Libras, até junto com ele, mas Libras tátil, aprender com surdocego, acho que não dá, né?!

Lia: É... pular etapa, mesmo, né?!

Sara: É, ele precisa... estando numa escola onde todo mundo conhecia Libras, eu acho que a inclusão dele foi... teve mais sucesso, assim. Ele iria ficar um pouco isolado, se fosse numa escola comum. 
Lia: Então foi um ambiente mais saudável, até...

Sara: Propício, eu acho. Propício. Porque... um ambiente linguístico totalmente apropriado para que ele se integrasse. Eu acho que isso fez muita diferença.

Um espaço propício, onde a diversidade e a pluralidade encontraram um ponto comum. E é isso que faz com que o bilinguismo seja um modelo inclusivo, tanto para os Surdos, como para um aluno com surdocegueira que utiliza Libras tátil. Ester nos dá mais informações sobre a riqueza de um espaço que favorece a ligação entre os comuns (communis + actio).

Lia: E os amigos conversavam com ele?

Ester: Tooodos. Imagina, ele brincava... todo mundo. Nem era só da sala. Da escola toda. A turma puxava ele. Ele ia sozinho, mas... ele ia sozinho para tudo quanto é lugar. Banheiro, comer, eu nem levava. Ele já sabia. Ele se virava lá. E tinha os amigos. Os amigos puxavam ele, e outro ia, e ele já sabia o que tinha que falar assim. Todos sabiam que ele era surdocego, então, eles já se comunicavam naturalmente com ele, sem precisar nada. Ele escondia as coisas dos outros. Fazia tudo o que os outros faziam.

Lia: Ele aprontava.

Ester: Tudo. Aprontava. Ia no banheiro, gritava. Aí eu, porque, eles faziam isso, né... "Uuuhhhh”. Assim, gritar no banheiro. Só que, ele ia no banheiro com os amigos, e um ensinou pra ele. Um Surdo ensinou. Ele fez no banheiro lá. Porque eu ouvi. Eu tava na sala. Quando ele chegou, eu falei... ah... você... você gritou no banheiro! Aí ele deu risada. Aí ele falou assim. "Que mentira”. Aí: "verdade. Eu ouvi você gritar”. Aí eu fiz assim, “Uuuhhh”, junto com ele, pra ele. Aí ele riu. "Verdade! Né?!" Aí eu falei: "Como?!” E ele ria. Quer dizer. Como que eu descobri, né?! Mas é lógico. Se todo mundo, por que que ele não vai fazer? Ele ia fazer também. Os outros também fazem. Ah! É coisa natural, de adolescentes. Então eu deixei ele fazer, né?! Eu não ia dar bronca nem nada, mas eu brinquei com ele. Eu falei: “mas eu ouvi você é... gritar, né?!” Tal, e ele lá, riu, brincou. Aí ele pegava assim, o estojo do amigo que tava do lado. Amicíssimo dele, o Lucas, gostava demais dele... e escondia. E aí eu falava assim. "Eu vi. Eu vi você, pegou, do amigo, o estojo, né?!" O Lucas levantava e ele, ó. Tal.

Lia: Pegava. 
Ester: E eu: "eu vi que cê pegou”. "Não é pra falar nada”. E eu falei: "Ah! Tá certo. Tá bom, tá bom. Brincadeira. Tá bom. Não vou falar nada”. Aí... então, ele tinha essa tirada, ele tinha essa coisa de saber...

Lia: Ele era um adolescente...

Ester: ... ele sabia o momento que era brincadeira. Que era, sabe, que eu não tava falando sério. Ele sabia disso, né?!

O direito de ser um adolescente, como todos os outros. De estar com esses outros. De brincar e "aprontar". E voltamos às considerações de Arendt (2004, p.274): manter a discriminação dentro da esfera social, quando é legítima, é distinção. E não estamos sendo repetitivos ao afirmarmos que manter os alunos Surdos e os alunos com surdocegueira, que utilizam Libras, na EMEBS, é assegurar um direito legítimo, e isso é inclusão. É garantir o distinguir-se, garantir o acesso à sua língua natural, a uma identidade cultural, e a um discurso em sua própria linguagem, e não na linguagem do ouvinte.

Porém, também é necessário impedir que a discriminação passe para a esfera política e pessoal, quando é destrutiva. Isto é, quando a discriminação deixa de ser distinção, quando ela não é uma escolha identitária ativa e ativista, e quando não tem como base aspectos linguísticos, religiosos, enfim, culturais, mas sim, apenas o preconceito. Isso significaria uma contaminação destrutiva para a esfera pessoal. Faria com que voltássemos à segregação e à marginalização como formas de discriminação pessoal.

São as discussões e os modelos de outros movimentos sociais que podem nos dar luz frente a essa questão. $\mathrm{O}$ caso das Historically Black Colleges and Universities (HBCU), que são faculdades e universidades nos Estados Unidos, historicamente para e de negros, que somam cerca de uma centena de instituições. Em São Paulo, temos a Zumbi de Palmares. Ouvir essas pessoas e compreender a necessidade de se garantir o direito de distinguir-se, é essencial ${ }^{77}$. Afinal de contas, estar junto não significa romper com preconceitos. O casamento inter-racial, sabemos, não evidencia a ausência dessa discriminação pessoal. Pelo contrário, é perniciosa, porque torna qualquer ação mais difícil ao transferir a discriminação para a esfera privada, para os gestos simples e cotidianos, para as "piadas" de todo dia, para a violência sutil que vem acompanhada de um sorriso. Ao ler sobre o racismo no Brasil na obra de Jessé Souza (2009),

\footnotetext{
${ }^{77}$ Essas reflexões tiveram como base uma série de palestras realizadas na Escola do Parlamento, da Câmara Municipal de São Paulo, nos meses de julho e agosto de 2016, sob o título "Políticas de Promoção da Igualdade Racial e a Década Internacional dos Afrodescendentes". Também é necessário citar as reflexões derivadas da Formação de Mediadores da $32^{a}$ Bienal de São Paulo, que contou com palestras e conversas com artistas negros de diferentes países.
} 
inúmeras outras discussões e reflexões sobre diversidade, distinção, alteridade, pluralidade e singularidade deixaram claro que a luta continua. Pensar sobre todos esses aspectos, sobre os preconceitos que impregnam toda a sociedade, é necessário e é urgente.

Se, como afirma Grada Kilomba ${ }^{78}$, o racismo é uma questão do branco, que precisa pensar sobre como pode desconstruir o preconceito que lhe é inerente; da mesma forma, o preconceito contra os Surdos é uma questão do ouvinte, e o simples fato de ouvir, nesta sociedade, nos transforma em opressores.

Skliar (2015, p.7) resgata, na apresentação da coletânea de trabalhos de diferentes pesquisadores, o termo por ele pensado já na década de 1990: “ouvintismo”, com suas derivações 79 . Suas discussões são extremamente pertinentes e nos permitem perceber o caráter colonizador que perdura, mesmo com o reconhecimento da Libras.

Então, não podemos deixar de finalizar as reflexões sobre o bilinguismo trazendo de novo, e outra vez, e mais outra, a questão que deve ser feita por todos os ouvintes ${ }^{80}$, na primeira pessoa: como posso desconstruir esse preconceito que, por mais que eu combata e negue, é algo inerente à minha condição de ouvinte?

\footnotetext{
78 Também de Grada Kilomba em "Lidando com o racismo na Europa". Disponível em: < https://www.youtube.com/watch?v=DdpUFybJddc>. Acesso em: 10 jun. 2016. Ver também parte da entrevista transcrita em: http://www.geledes.org.br/grada-kilomba-lidando-com-o-racismo-na-europa/\#gs.VUB6IAE. Publicado em: 22/09/2014. Acesso em: 15 jun. 2016.

${ }^{79} \mathrm{E}$ não podemos deixar de dar crédito aos alunos do curso de especialização em Libras da UnYLeYa, que insistiram para que reconhecêssemos a validade deste conceito que não nos parecia correto, pois o sufixo "ismo", também presente em racismo, é usado para indicar práticas e doutrinas que associamos à perpetração de ações violentas. Assim como o racismo, isso abre margem para um lugar onde todos os ouvintes poderiam se esconder. Ruffato (2014) reuniu uma série de discussões em seu artigo, e uma delas é sobre a hipocrisia brasileira: "Aqui, o racista é sempre o outro. Pesquisas apontam que 97\% dos entrevistados afirmam não ter qualquer preconceito de cor, ao mesmo tempo em que admitem conhecer, na mesma proporção, alguém próximo (parente, namorado, amigo, colega de trabalho) que demonstra atitudes discriminatórias. É o chamado "racismo à brasileira" - fruto direto da cínica e equívoca "democracia racial", conceito que vem justificando, ao longo da história, a manutenção de um dissimulado apartheid, que segrega a população não-branca à base da pirâmide social."

$\mathrm{O}$ "ouvintismo" também é um preconceito que muitos ouvintes combatem e negam, mas que é inerente à condição de ouvinte. O "ouvintismo" permite uma não identificação, a possibilidade de ouvintes afirmarem que "eu não sou ouvintista". Mas frente aos surdos, somos maioria. Essa simples maioria numérica, como lembra Arendt (2011, p.230) "é sempre consideravelmente mais forte e tirânica do que a mais severa autoridade de um indivíduo isolado". Portanto, não utilizamos esse conceito com frequência porque compreendemos que todos os ouvintes devem perceber-se como "ouvintistas". E essas considerações também partem da fala de Grada Kilomba.

${ }^{80}$ Em uma "paráfrase" de Grada Kilomba que propõe a pergunta: "Como eu desconstruo meu próprio racismo?"
} 


\subsection{QUEM PODE... QUEM NÃO PODE...}

Como combater, como desconstruir esse preconceito que é inerente à nossa condição de ouvintes? As narrativas das colaboradoras e as considerações sobre a escola bilíngue, nos levaram a pensar, pois, sobre a questão da normalidade. E é sobre esse ponto que nos debruçamos para buscar caminhos que possibilitem a libertação dos preconceitos.

Nesse sentido, pensar sobre essa crença no "quem pode... quem não pode...", leva à reflexão sobre perguntas como: Quem pode estudar aí? Quem pode trabalhar aí? E por quê?

\subsubsection{A contradição da especialização}

Se a EMEBS é uma escola bilíngue, e o aspecto cultural é o mais importante, a antiga ideia da especialização em deficiência auditiva está sendo suplantada. E essa reflexão sobre a especialização pode ser ampliada para toda a rede de ensino. Uma ideia que nos é recente e que remete a algo que aconteceu no início de um evento organizado pelo CEFAI/DOT-P da DRE Ipiranga, em 2012. Sobre o palco, todas as PAAI começaram a apresentar-se. O ser PAAI também requer uma especialização para que ocorra a designação. Em meio às falas, cada PAAI dizia o próprio nome e a sua "especialidade": Deficiência Visual, Deficiência Auditiva, Deficiência Múltipla... até que uma colega afirmou sem titubear e com extrema clareza "meu nome é Renata Garcia e eu sou especialista em educação".

Essa saída do roteiro nos causou um rompimento de imediato. Era como se a resposta a várias questões antigas e essenciais que causavam incômodo se colocasse ali, em cerca de dez palavras. Uma síntese exata do que vinha sendo afirmado para os professores e demais educadores das unidades onde o CEFAI dava apoio: "Sim, você, professor, pode e deve receber todo e qualquer aluno". Mas isso parecia ser paradoxalmente contestado ao se exigir a especialização para a assunção do papel de PAAI. Enfim, a resposta que buscava para as formações que acompanhava: todos esses alunos com e sem deficiência, estão na escola, local onde todas as crianças e adolescentes devem estar, porque é onde eles podem estar sob a orientação de especialistas da educação.

Independentemente do fato de uma criança com deficiência física, por exemplo, necessitar de fisioterapia - o que certamente deve ser assegurado em instituições de saúde -, ou de uma criança com Síndrome de Down, que precisa de terapia fonoaudiológica - que também deve ser assegurada em clínicas ou instituições próprias para isso -, no espaço escolar, essas 
crianças, adolescentes e jovens devem ter assegurado seu direito e acesso à educação ${ }^{81}$. E são especialistas em educação que não podem faltar nas escolas!

Sim, o conhecimento sobre as síndromes ou causas de deficiência é positivo, se liberto da tendência à lógica da medicalização e da institucionalização. Sim, o acesso a essas informações também é relevante, principalmente em cursos complementares, mas não deve ser nem o único foco, nem o principal, para o professor que está na sala de aula regular. Como proposto por Maia (2011, p.127), no tema que nos interessa mais diretamente, as Secretarias Municipais e Estaduais de Educação devem realizar cursos de formação continuada e implantar serviços complementares ao atendimento educacional de pessoas com surdocegueira em qualquer rede regular de ensino. Por isso, pensando no cenário da RME de São Paulo, destacamos a importância e a necessidade da manutenção e ampliação de parcerias com educadores que atuam nas SAAI e em instituições especializadas conveniadas que realizem, no contra turno e em caráter complementar, atividades em modalidades como o Atendimento Educacional Especializado (AEE), Atividades de Enriquecimento Curricular (AEC), de Iniciação ao Mundo do Trabalho (IMT), sob o apoio e coordenação atenta das PAAI - para se evitar, também, uma sobrecarga que pode vir a ser um desrespeito à criança ou ao adolescente.

Na rede municipal de São Paulo, várias instituições vêm realizando as formações dos professores da sala de aula regular, dando-lhes subsídios para que saibam adequar os conteúdos de forma concreta e contextualizada. Isso acaba propiciando o aprendizado de todos os demais alunos da sala, pois quando o olhar para a diferença passa a ser considerado, há a possibilidade de libertação desse delírio paranoico que marca a sociedade administrada, pois como bem nos alertaram Adorno e Horkheimer (1985), a patologia está na ausência de reflexão. Porém, perdura o risco: em espaços marcados pela semicultura, pode-se recorrer "estereotipadamente à fórmula que lhe convém melhor em cada caso, ora para justificar a desgraça acontecida, ora para profetizar a catástrofe disfarçada, às vezes, de regeneração" (ADORNO; HORKHEIMER, 1985, p.161).

Portanto, no cenário atual - que enxergamos como um momento de transição -, os professores das SAAI e das instituições especializadas exercem, ainda, um importante papel de conexão com uma rede que deve envolver os profissionais da saúde que atendem os alunos, que dialogam com os familiares, que mantêm contato com os CEFAI, entre outros. Porém, no espaço da sala de aula, com os professores, especialistas em educação, da sala regular, recorremos

\footnotetext{
${ }^{81}$ Souza $(1998$, p.147) já apontava para a questão ao lembrar que "o problema não resulta dos exercícios em si, [...] mas do fato de acabarem por ocupar, nas escolas, papel privilegiado, em detrimento do ensino propriamente dito. E por serem fundamentados numa concepção de ensino de língua que leva à produção de uma fala morta."
} 
novamente a Arendt (2011, p.239) para afirmar que as crianças estão presentes nesse lugar para serem apresentadas ao mundo, em seu papel de aluno ou aluna, tendo acesso a diferentes conteúdos culturais.

Manzini (2007) nos mune com outras informações sobre essa questão da especialização docente ao resgatar um histórico da legislação específica à educação e aos direitos das pessoas com deficiência ${ }^{82}$. Segundo esse autor,

Já é possível vislumbrar, em vários currículos de cursos de pedagogia, a inserção de
disciplinas que objetivam promover a formação do futuro professor no atendimento a
alunos com deficiência em situações de ensino comum. Isso tem ocorrido mais rapi-
damente em faculdades particulares que estão modificando o perfil dos cursos na di-
reção da inclusão.
Assim, atualmente, ao optar pela carreira docente, implicitamente, ofuturo professor
já está obrigado - segundo Lei no 7.853 de $24 / 10 / 1989$ [...], que dispõe sobre discri-
minação e crime - a atender alunos com ou sem deficiência, não sendo mais a popu-
lação de alunos com deficiência somente da alçada do professor especializado. [grifo
nosso]

E é esse cenário que podemos vislumbrar para um futuro próximo: todos os professores e todas as professoras especialistas em educação, para todas as crianças e adolescentes. Da mesma forma, todos os educadores das Diretorias de Ensino, tanto na Diretoria de Orientação Técnico-Pedagógica como na Supervisão, capazes de falar e orientar sobre os aspectos relacionados à educação de todas as crianças, sem setores ou profissionais especializados na educação de pessoas com deficiência, porque isso deverá ser um conhecimento universal. O mesmo se aplica à questão racial, pois as formações sobre as questões étnico-raciais devem ser compreendidas como prioritárias se queremos superar as antigas respostas.

Ressalve-se que no caso dos Surdos é necessária muita atenção, porque a Libras é um elemento chave para a educação. Assim, nas EMEBS, devemos lembrar que são necessários professores e professoras especialistas em educação, fluentes em Libras e que conheçam a Cultura Surda. E pensando em termos ideais: professores Surdos e professoras Surdas. Neste aspecto, deve-se compreender que a criação das atuais EMEBS pelo Decreto $n^{\circ}$ 52.785, de 10 de novembro de 2011, é pioneira. No parágrafo primeiro de seu quinto artigo, ao especificar quais profissionais podem atuar nas EMEBS, determina:

$\S 1^{\circ}$. Para atuar na regência das classes/aulas, o profissional de educação, além da habilitação na área de atuação, deverá apresentar habilitação específica na área de surdez, em nível de graduação ou especialização, na forma da pertinente legislação em vigor, e domínio de LIBRAS.

\footnotetext{
${ }^{82}$ E deixamos os agradecimentos à Rosiane, que nos apresentou este texto de Manzini.
} 
A exigência de uma "habilitação específica na área de surdez" para a possibilidade de escolha dessas unidades como unidade de lotação e exercício pelos professores, pode parecer uma incoerência. Porém, ao referenciar Surdez - apesar da legislação não utilizar a inicial maiúscula - e não deficiência auditiva, indica um uma mudança radical da legislação que anteriormente previa especialização em deficiência auditiva. E apesar da inicial minúscula, Surdez, como desde a legislação federal de 2002 vem sendo esclarecido, diz respeito a usuários de Libras e à Cultura Surda.

Certamente, ainda há muito a se pensar. Por exemplo, em uma situação onde uma pessoa adulta ouvinte, que faz parte da Comunidade Surda, filha ou filho de Surdos, fluente em Libras, professora ou professor da RME, deveria ter prioridade para indicar a EMEBS na escolha de vagas. Ou ainda, acreditando efetivamente em respostas "novas" ${ }^{\prime 3}$, há a necessidade de concursos específicos voltados para professores Surdos e professoras Surdas, fluentes em Libras, para atuarem nas EMEBS. Isso porque, não pecamos ao reforçar, a partir do momento em que a própria legislação reconhece a diferenciação entre pessoas com deficiência auditiva e pessoas da Comunidade Surda, evidencia-se a compreensão da Surdez como uma característica cultural e as EMEBS deveriam ser Escolas Municipais de Educação Bilíngue para todas as pessoas da Comunidade Surda, incluindo a possibilidade de matrícula, por exemplo, de crianças ouvintes, filhas de pais Surdos, cuja língua materna é a Libras.

Porém, se inicialmente a lógica da especialização em educação especial perdurou, isso vem sendo desconstruído pouco a pouco. Isto porque nas EMEE eram as professoras de Ensino Fundamental I que assumiam as aulas do Ensino Fundamental II, porque não haviam os especialistas habilitados para assumir as aulas - e neste caso, referimo-nos aos especialistas em disciplinas como matemática, português, história, ciências, entre outros. Assim, com a transformação para EMEBS, houve uma movimentação importante e interessante para formar professores da RME que se comprometessem a ir para as EMEBS que, vinha, de certa forma, contaminada pelo antigo modelo e ao mesmo tempo, buscava desconstruí-lo.

Ester: Foi isso que a gente até na época, a gente ficou meio assim. Porque a gente dava, eu sei, eu acho que o aluno tem direito, com a especialista, sim, porque ele estudou praquilo. Só que muitos anos, ficou a gente dando essas aulas. Lógico, e se esmerando, indo atrás, conhecendo, não é a mesma coisa que

\footnotetext{
${ }^{83}$ Utilizamos as aspas porque, apesar de considerarmos novas, são ideias antigas quando vemos o exemplo da California School for the Deaf (Escola para Surdos da Califórnia), em Fremont (SACKS, 1998, p.71) que evidencia a importância de Surdos adultos.
} 
um especialista. Lógico que não, né. Não na mesma profundidade. Mas não existia, por que? Porque as pessoas não vinham. Então, por si, elas não vinham fazer o curso como a gente fez no EDAC, mais um ano pra depois estar aqui. E aí, é lógico, a pós, a gente até ficou meio que questionando, não questionando. Questionando assim, eles vieram, é ótimo, eles têm direito, os alunos têm direito a aulas com professor de Fund II, mas então por que que não fazer o inverso também. A gente que tava aí, que se me desse para fazer, eu gosto muito de biologia. Se tivessem me dado a oportunidade, na Prefeitura, de eu fazer biologia, pra que eu depois fizesse, eu faria. [...] Mas se a oportunidade foi dada para os de Fund II, desse para os de Fund I, porque a gente já estava aqui, já.

Muitos professores que não conheciam a Comunidade Surda, que não sabiam a Libras, mas houve uma seleção seguida de uma formação - em nível de especialização - para que eles pudessem assumir as aulas nessas unidades, "mas então por que que não fazer o inverso também”? Por que as políticas públicas compreendem a especialização em Surdez como sendo muito mais simples do que uma segunda graduação, como muitas instituições de ensino superior proporcionam? E se é de ensino de idioma que estamos falando, como se pode conhecer e dominar uma nova língua em um ano e meio?

Sim! Os avanços são inquestionáveis. As ações realizadas na RME foram importantes e eram necessárias, e estão muito à frente da grande maioria das cidades que têm mantido a compreensão do conceito de inclusão presa à sua origem etimológica, fechando as portas das escolas para Surdos. Porém, a questão permanece: como desconstruir esse preconceito que é inerente à nossa condição de ouvintes? Como deixar de pensar seguindo a mentalidade da educação especial? Por que voltamos sempre à questão da "adaptação" ao mundo ouvinte quando falamos sobre a Educação Bilíngue para Surdos? Isso não evidencia nossa prisão ao modelo de educação especial que segue a lógica da integração, e não da inclusão?

Rute, uma professora que foi formada nesses programas para professores de Ensino Fundamental II assumirem as aulas nas EMEBS, apresenta a questão do choque cultural.

Rute: No começo foi bem difícil, de entrar na sala, eles virarem as costas pra gente, saírem da sala, não aceitarem. [...] Aconteceram algumas vezes, porque era, né, você não conseguia. No começo, era muito difícil, porque você não conseguia acessar eles, né. É... e não explicavam isso na pós-graduação. Ninguém explicou isso. 
"Ninguém explicou isso". Ninguém avisou que encontrariam uma Comunidade Surda, com um repertório cultural próprio, e que um dos elementos mais importantes era o domínio da Libras e não conhecer a anatomia da orelha interna, média e externa. Mas, como já foi indicado anteriormente, mesmo as formações na área de Surdez vêm sofrendo transformações nesse sentido.

Ao mesmo tempo, é necessário ressalvarmos o fato de que devem ser mantidas as formações que abrangem as discussões legais sobre as pessoas com deficiência para que se assegure a diversidade nos tipos de atendimento. Por exemplo: se um adolescente perde a audição no segundo ano do ensino médio, pode ser muito mais rápida uma reabilitação oral com o uso de prótese auditiva e treinamento fonoaudiológico, e sua permanência em uma escola regular com orientações específicas que facilitem a leitura labial e a manutenção da oralidade. Portanto, não se trata de extinguir os especialistas que atuam com terapias da fala. Um cenário diferente do tratado neste trabalho.

Aqui, estudamos as escolas bilíngues para Surdos, onde pessoas fluentes na Libras são essenciais para o sucesso do aprendizado.

Rute: É... na escola, eu acho que já a partir de 2012, com toda a legislação nova, a gente tinha instrutores Surdos, né. E aí, eles ajudavam, também, bastante. Tinha um horário, específico, onde ele dava aula pra gente.

Lia: Para os professores?

Rute: Eram instrutores Surdos. Larissa...

Lia: ... é, dando aulas para os professores da escola.

Rute: Isso. É, eles davam, na realidade, no contrato deles eles têm que atender os professores, os alunos e a comunidade. Então, eles têm horário com todos os alunos, têm horário com os professores, horário com os funcionários da escola, e tem horário aberto para a comunidade, também. Então em todas as EMEBS você tem aulas de Libras, para a comunidade... ou deveria ter. Mas em todos... todas... é... isso é o que consta no contrato. Então, de... e o contato, né. É aquilo que a gente fala de língua, né. Como se aprende língua.

Lia: Imersão, né?!

Rute: Imersão na língua.

Lia: Todos os dias na escola.

Rute: Exato. 
"Imersão na língua", com a presença de adultos Surdos ou adultos ouvintes fluentes em Libras - apesar de acreditarmos que somente adultos Surdos tem total fluência em Libras, ainda há poucos profissionais e isso faz com que ouvintes fluentes em Libras sejam importantes nesse cenário de transição -, porque é "como se aprende língua”. Sem a entrada massiva de pessoas da Comunidade Surda nessas unidades, a Libras não se solidifica como a língua efetivamente majoritária.

Sara: Porque quando a gente... olha... quando entrou a Larissa, pra dar aula ali no primeiro, segundo ano de... do ensino fundamental, que ela dava aula, primeiro de Libras, e entrava também... ela era acho que professora que substituía, cê precisa ver o crescimento que os alunos tiveram. Não, não te falo na língua, porque é muito comum professor de Surdos achar que o aluno bom é o aluno que sabe bem a língua portuguesa escrita. E na verdade ele precisa saber dos conteúdos, né?! Cê precisa ver como aquelas crianças avançaram nos conteúdos.

Lia: Pra discutir os assuntos...

Sara: Ciências, história, ... é, e geografia, e questões assim, pequenininhas, de bairro, de... ela ia com eles até a quitanda, ia com eles até o supermercado, $e$ falava sobre frutas, verduras, e...., cê precisa ver, era uma coisa bárbara! Mas era fluência, né?! Professora surda, né?! Eles respeitam mais, também.

Educadores adultos, Surdos, que vivem as experiências de forma visual. Que defendem a Libras como um direito que, muitas vezes, lhes foi negado quando crianças. Que compreendem a relação Surdo-ouvinte com todas as implicações presentes aí. Que podem, inclusive, pensar seguindo políticas afirmativas da Cultura Surda. Sim. Porque sem a entrada massiva de pessoas da Comunidade Surda nessas unidades, essa cultura não se solidifica como a cultura efetivamente majoritária.

Sara: Ou então, até em questões assim, bem do dia a dia mesmo, assim. Por exemplo: quebrava o sinal luminoso do intervalo, vai. E aí, funcionava só o sonoro. Por exemplo. Não tinha... era... ah... se a gente [da equipe gestora] não tivesse percebendo e chamado alguém pra ir lá consertar, não tinha assim, no coletivo de profissionais que trabalhavam "olha, como assim, tá quebrado. Tem 
que arrumar, e tal". Começou isso quando entrou um professor Surdo. Então, quer dizer, a gente não prestava tanta atenção naquilo que precisava pra... pra realmente a escola ter um ambiente visual, assim, apropriado.

Evidentemente, já se passaram cerca de cinco anos desde a criação da EMEBS e muito tem mudado. Porém, como podemos notar na entrevista de Lídia, nos primeiros anos, a questão da língua continuava não sendo priorizada como deveria ${ }^{84}$ :

Lídia: E também, tem que falar em Libras, tem que responder em Libras. Mas ficava tudo muito... porque é uma luta, também, na escola bilíngue e a gente não consegue fazer isso, né?! O Luís, que é um... que luta muito por isso. "Tem que fazer. Tem que... na sala dos professores, o tempo todo Libras." A gente fala muito. A gente não consegue sair disso, né?! Essa coisa do falante, aí, a gente vai, um pouquinho ali, mas isso precisaria mudar. A gente tentou fazer um ano, mas não deu muito certo. Só a JEIF... mas, ah! Tentamos, mas aí a gente não conseguiu entrar num acordo, se realmente era uma coisa viável ou não. Eu, tenho também, algumas dúvidas sobre isso, mas eu acho que era melhor você não entender totalmente o contexto, do que ficar... porque a gente sempre fala isso: "Ah, mas chega uma hora que eu não vou compreender." Então levanta e pergunta, era melhor que fosse assim, do que a gente nunca fazer isso, nunca esse exercício.

E Lídia complementa:

Lídia: Então. Isso falta. A gente não consegue. Aí você vai obrigar? Não sei se tem alguma escola que já consegue se policiar aí o tempo todo. Eu fico pensando assim... seria tão mais gostoso, e a gente aprenderia muito mais, porque...

Lia: Realmente como uma primeira língua mesmo, em todos os espaços, né. Lídia: Ai, mesmo, o tempo todo, com os ATEs, com o pessoal, a gente ia treinando. No começo ia ser uma coisa meio estranha, né?! Mas é isso. Imagina o quanto que a escola também ficaria mais interessante até em termos de som, né?! Porque a... gente, é muito barulhento, a escola. A nossa escola também é,

\footnotetext{
${ }^{84}$ E se Rute nos informa que ainda hoje há professores oralistas, essa reflexão se mostra urgente.
} 
né, a EMEBS, embora seja de Surdo, e a... é muita fala. Fala junto com a criança, faz sinal e fala junto, mas fala, às vezes grita, né. Eu acho que seria muito mais gostoso.

A EMEBS é recente e um conceito que ainda está em construção, que ainda exige muitas reflexões quando se pensa a compreensão do público-alvo. Uma compreensão que precisa manter-se imune à ideia da normalidade, conforme pensada por Goffman (2008, p.14), e de acordo com as discussões de Adorno e Horkheimer (1985, p.136-137) que combatem a "fórmula petrificada" e as "designações arbitrárias e manejáveis".

A EMEBS é uma escola para Surdos e não é a melhor opção, necessariamente, para todas as pessoas com deficiência auditiva. E, apesar do interesse de muitos Surdos adultos em acolher todas as pessoas com perda auditiva, a decisão final entre oralismo e bilinguismo, cabe à família. Por isso, acesso à informação para todas as pessoas. Possibilidade de contato direto com os Surdos adultos. Caso contrário, vemos a incoerência se repetindo:

Lia: Porque agora também tem muitos alunos chegando com... Ifiz o sinal de implante coclear]

Lídia: Ah! Com implante. Os pequenininhos da educação infantil, todos com implante, né.

Lia: E aí, como é essa conversa? Não sei se os pais querem que fale.

Lídia: Nós tivemos duas ou três palestras, sobre a... a Laura, que é a fono, fez uma vez. Chamaram uma outra pessoa, também, pra falar do implante coclear, no sentido assim, né, até o Surdo falando, dando a opinião... só que é assim, é complicado pra mãe. A mãe fica muito dividida, porque nasce a criança, se descobre, dependendo do médico que já orienta, elas ficam divididas. Eu acho que elas são... é uma geração que vai ficar assim, um pouco confusa. Eu não entendo como é que vai ser isso, porque eles têm o implante, muitos deles não fazem nem fono...

Lia: $A h !$

Lídia: Tem implante, mas não tem a fono garantida. Porque é isso, deveria ter isso associado. Ter o implante junto com a fono, né, mas muitos não tão fazendo fono. Só têm o implante. Essa informação, ou porque não conseguiu, ou porque está esperando, porque quem tem condições de pagar, paga. E quem não tem,... cê depende de uma série de coisas. Então, é uma coisa meio mal orientado e... 
mas é muito forte, essa coisa do implante porque acho que falam: "não, vai, porque vai falar..." então, e ao mesmo tempo, a criança tá lá, fazendo isso aqui, né [sinal de língua de sinais]. Não sei como é que vai ser, acho que as meninas que tão aí trabalhando é que tão vendo, mas o que é feito é isso: a professora acaba, muitas vezes, falando e fazendo Libras. Mas é uma outra discussão, né.

Alunos com implante coclear, sem acompanhamento fonoaudiológico, em uma escola bilíngue. Um cenário que evidencia a confusão. Novamente: não se está optando pela escola por conta da língua, mas porque são crianças com deficiência auditiva? Ou porque são crianças com deficiência auditiva cujo processo de oralização não se efetivou? Há algo a ser questionado e pensado nesse cenário; há a necessidade de acesso à informação para que não se fique preso à paranoia ${ }^{85}$.

E a paranoia nos cega, nos faz crer que sem uma formação, não somos capazes. E isso também se estende ao tema que aqui estudamos. Quando se dá o nome, ainda preso ao preconceito, o medo se instaura. Foi o que ocorreu quando se informou que chegaria um aluno com surdocegueira. Isso porque, como nos informa Sara:

Sara: Eu acho que eu tenho que ressaltar que a gente, já, na verdade, já atendia surdocegos, porque a gente tinha muitos Surdos com baixa visão, na escola. Então, eu não posso dizer que o Fábio foi o primeiro surdocego. Mas na verdade, ele foi o primeiro surdocego com essa, vamos dizer, denominação pro aluno, porque o outro com baixa visão, ele, dentro da escola, ele não era visto como um aluno com surdocegueira. Ele era um aluno Surdo que tinha baixa visão, como se isso não fosse uma deficiência única. Isso ainda não estava claro, sabe, pra nós, nem pros professores, e nem pra mim.

O fato do Fábio ser um surdocego que tem uma surdez severa e vai, uma... e... cegueira, isso... eu acho que, ele é um surdocego, assim, não sei se a gente pode dizer, “clássico”, sei lá, ele...

Lia: Como todo mundo imagina que todos são, né?!

\footnotetext{
${ }^{85}$ E aqui, fazemos referência a Adorno e acreditamos que, a partir da informação, há a abertura para o diálogo e a reflexão, e à formação de novos conceitos, de novos cenários, de novos repertórios. Isso pode engendrar um ciclo que faz com que a emancipação seja uma possibilidade que, evidentemente, requer muito mais do que a informação, mas que não pode prescindir dela.
} 
Sara: Isso! Então, quando eu fui ver... ah... fazer essa pesquisa na legislação, aí que eu me toquei que eu já atendia surdocegos. Né?! E aí, isso facilitou muito quando eu fui preparar os professores para receber esse aluno, porque, nesse momento, como ele era o primeiro aluno, a gente nem tinha pensado em guiaintérprete, nem a secretaria tinha pensado em como trazer alguém para auxiliar esse professor... então, tudo era novo, né?! Quando eu cheguei com esse desafio para os professores, a gente não tinha na verdade nada. Foi construído, lá.

A formação evidenciou que esse "primeiro" aluno com surdocegueira não era o primeiro. Outros já estavam matriculados nessa unidade, mas não havia uma efetiva compreensão desse público e de suas necessidades. Portanto, sim, a formação continuada é importante e valiosa. Sem esse conhecimento, sem o aprofundamento teórico, as justificativas para a criação de políticas públicas também seriam muito frágeis. Mas quando pensamos na diversidade humana, é impossível conceber uma formação prévia plena, capaz de fornecer respostas a todas as questões. E novamente, recorremos à ideia da rede, que aparece na fala de Ester com relação a outro aluno.

Ester: E eu crio também, a [nome de instituição conveniada à RME] é referência, então é lógico, dúvidas maiores, eu também vou lá, ai, me ajuda, como que faz isso aqui, ah! Pode fazer isso? Porque como ele tinha esse problema, também, físico, mas ele tinha uma marchinha, então se você pegava na mão, ele ficava de pé, ele vinha com a marchinha. Mas ele tinha um pezinho meio assim, e eu pensei, será que eu posso fazer isso ou não. Já entra em outro, outra...

Lia: Isso, aí são os especialistas na área de saúde...

Ester: Aí eu falo com a mãe ou com os especialistas.

Lia: ... para orientar, né.

Ester: Porque na [nome de instituição conveniada à RME] tinha a fisioterapeuta, então quando fui na [nome de instituição conveniada à RME], ela também me orientou. Não. Você pode fazer isso.

Lia: Legal.

Ester: O que acontece? Essa troca, ajudava muito. Porque, né, ah! Agora fico livre e fico descansada, porque eu não tô prejudicando o menino. 
“Essa troca, ajudava muito. ”E não ajudaria todos os professores e todas as professoras, em seu trabalho com todos os alunos e todas as alunas? Uma rede envolvendo profissionais de saúde, educação, instituições especializadas conveniadas, pais e toda a comunidade escolar. Isto é, a constituição de uma comunidade real. Delegar a responsabilidade aos professores de "se especializarem", não lhes forneceria subsídios para saber se a marchinha prejudica ou não o aluno. Orientações relacionadas à saúde das crianças e adolescentes devem ser dadas pelos profissionais da saúde e pelos nutricionistas.

\begin{abstract}
A ação e o discurso ocorrem entre os homens, uma vez que a eles são dirigidos, e conservam sua capacidade de revelar o agente [agente-revealing] mesmo quando o seu conteúdo é exclusivamente "objetivo", dizendo respeito a questões do mundo das coisas no qual os homens se movem, mundo este que se interpõe fisicamente entre eles e do qual procedem seus interesses específicos, objetivos e mundanos. Esses interesses constituem, na acepção mais literal da palavra, algo que inter-essa [inter-est], que se situa entre as pessoas e que, portanto, é capaz de relacioná-las e mantê-las juntas. (ARENDT, 2010, p.228)
\end{abstract}

Enquanto a educação das crianças, dos adolescentes e dos jovens não for assumido como sendo do interesse de todos os adultos, se a formação dessa rede, a educação tende à falência. É necessária a communis + actio entre os adultos, para que se garanta a apresentação do mundo para os novos, sendo-lhes garantida a segurança do ocultamento (ARENDT, 2011, p. 238).

\begin{abstract}
A maior parte da ação e do discurso diz respeito a esse espaço-entre [in-between], que varia de grupo para grupo de pessoas, de sorte que a maior parte das palavras e atos refere-se a alguma realidade objetiva mundana, além de ser um desvelamento do agente que atua e fala. [...] Esse segundo espaço-entre subjetivo não é tangível, pois não há objetos tangíveis nos quais ele possa se solidificar: o processo de agir e falar não pode deixar atrás de si tais resultados e produtos finais. Mas, a despeito de toda a sua intangibilidade, o espaço-entre é tão real quanto o mundo das coisas que visivelmente temos em comum. Damos a essa realidade o nome de "teia" de relações humanas, indicando pela metáfora sua qualidade de certo modo intangível. (ARENDT, 2010, p.228-229)
\end{abstract}

Uma rede composta por adultos, formando uma teia de relações e interesses a partir da comunicação. Isso é ação comum. Isso é estar entre. Isso é responsabilidade coletiva.

\title{
5.4.2 O abandono do monumento invisível
}

Propomos, pois, uma reflexão, a partir das discussões de "Elementos do Antissemitismo: Limites do Esclarecimento" (ADORNO; HORKHEIMER, 1985, p. 139-171) para apresentarmos o que compreendemos como sendo o direito a uma adaptação imperfeita, porque livre da falsa ordem social, da falsa ideia de normalidade, e consequentemente, capaz de permitir a superação dos limites do esclarecimento. 
Adorno e Horkheimer (1985, p.156), ao escreverem sobre a ausência de reflexão, característica do antissemitismo, afirmam: "Ele perde a reflexão nas duas direções: como não reflete mais o objeto, ele não reflete mais sobre si e perde assim a capacidade de diferenciar." E um pouco adiante, lembram: "Na medida em que o paranoico só percebe o mundo exterior da maneira como ele corresponde a seus fins cegos, ele só consegue repetir o seu eu alienado numa mania abstrata." (ADORNO; HORKHEIMER, 1985, p.157)

Manias abstratas: como preparar os Surdos para um mundo de maioria ouvinte? O delírio paranoico: como podemos deixar de nos preocupar com essa preparação? Percepção distorcida: como eles poderão ser felizes se não forem como nós? A repetição do eu alienado numa mania abstrata.

Então, sendo a EMEBS o resultado de uma luta empreendida pelos próprios Surdos, é nela que vemos a possibilidade de novas respostas, de pequenas mudanças que demonstram, ao menos, uma tentativa de deixar essas manias abstratas e que, pouco a pouco, devem permitir a saída voluntária e consciente desse monumento invisível.

Sara: Como eu discuto muito e tentei também conversar um pouco com os professores na época sobre a avaliação em português. Porque eu acho assim: se a língua de instrução é Libras, a gente teria que avaliar em Libras alguns conteúdos e avaliar em português, a segunda língua. Na minha opinião. Tanto que a gente tinha, então, uma filmadora para cada classe.

Lia: Tinha uma filmadora para cada?

Sara: Uma filmadora para cada classe. Porque eu gostaria que as avaliações fossem registradas em Libras. Por exemplo: conteúdo de ciências. Aprendeu hoje sobre células. Então você faria a pro... as perguntas, e o aluno responderia em Libras sobre a questão da célula. E depois, ele poderia ter o registro daquela avaliação em português. Mas, acredite, não deu certo. Não deu certo, apesar de ter tudo pra dar. Não deu certo, porque o professor, ele relutou muito em não ter avaliação em português, no papel, e... porque o registro do filme, ele pode ser arquivado, sem nenhum problema, né?! Não teria problema. E assim, olha, Lia, é o que eu falava pros professores, né. Imagina a gente, por exemplo, ir num lugar aprender alguma coisa em português, por exemplo, algum... assistir uma palestra em português, mas depois na hora de eu responder eu ter que responder em inglês. Se fosse para eu responder em português, eu ia acertar muito 
mais. Eu ia saber muito mais. Como é em inglês que eu tenho que fazer a avaliação, eи vou me restringir um pouco. Porque eu não tenho o domínio daquela língua, né?! Então, eu sempre pensei que tinha que ter a avaliação em Libras, coisa que a gente não tinha. Não deu certo.

Não deu certo... mas há aí uma semente. Uma reflexão sobre a realização da avaliação de forma condizente com a realidade cultural dos Surdos. E não cabe a ideia da adequação ou adaptação, porque já não estamos mais falando sobre educação especial nem sobre educação de pessoas com deficiência. Estamos falando sobre educação, e para ela ser inclusiva, exige respeito. Respeito à cultura, à diversidade e à pluralidade.

"Imagina a gente, por exemplo, ir num lugar aprender alguma coisa em português [...], mas depois na hora de eu responder eu ter que responder em inglês". Por que não? Afinal de contas, saber inglês para viver em um mundo globalizado é essencial. Mas por que não? Por que quando nos atinge, é uma proposta que soa absurda? Por que acreditamos que no caso dos Surdos não é violência? Talvez a solução dessa questão esteja na ideia da clausura, do retorno às mesmas respostas, à escolha do que é sempre a mesma coisa, a evidência de que somos, sim, limitados e não esclarecidos... porque não conseguimos aceitar plenamente o que está fora da norma e elaboramos explicações que voltam à crença em uma suposta igualdade para além da esfera política. E essa igualdade, nada mais é do que a falsa projeção de uma norma: se eu aprendi a ler e a escrever português, por que eles não conseguem? Como eles podem não que$r e r ?^{86}$

"Se o antissemitismo baseia-se numa falsa projeção", o ouvintismo também baseia-se numa falsa projeção, e "o sistema alucinatório torna-se a norma racional no mundo" (ADORNO; HORKHEIMER, 1985, p.154). Porém, esses autores lembram que o "patológico do antissemitismo não é o comportamento projetivo enquanto tal, mas a ausência de reflexão que o caracteriza" (ADORNO; HORKHEIMER, 1985, p.156). Paranóia: incapacidade de libertar-se de juízos consolidados, de normas estabelecidas (ADORNO; HORKHEIMER, 1985, p.160). Semicultura: não reflexão e a recorrência a fórmulas (ADORNO; HORKHEIMER, 1985, p.161).

Eis aí o segredo do embrutecimento que favorece o antissemitismo. Se, no interior da própria lógica, o conceito cai sobre o particular como algo de puramente exterior, com

\footnotetext{
${ }^{86}$ A esse respeito, o estudo realizado por Guarinello ( et al., 2009), sobre o letramento, amplia a reflexão sobre a alfabetização e é uma leitura necessária. Porém, peca ao não realizar essa análise com um grupo controle de ouvintes, pois a dificuldade em expressão escrita, assim como de compreensão na leitura de textos, não se restringe aos surdos - e essa informação consta no artigo, mas a pesquisa foi realizada apenas com surdos.
} 
muito mais razão, na sociedade, tudo o que representa a diferença tem de tremer. As etiquetas são coladas: ou se é amigo, ou inimigo. A falta de consideração pelo sujeito torna as coisas fáceis para a administração. Transferem-se grupos étnicos para outras latitudes, enviam-se indivíduos rotulados de judeus para as câmaras de gás. (ADORNO; HORKHEIMER, 1985, p.166)

E novamente, resgatando as discussões de Arendt (2004, p.274) com as reflexões de Adorno e Horkheimer, é essencial manter a diferença entre o distinguir-se e o ser rotulado. Quando uma pessoa Surda identifica-se culturalmente e exige a segregação, isso é muito diferente de quando os "normais" rotulam um conjunto de pessoas como "especiais" e os segrega. Assim como quando se cria uma escola judaica, isso é totalmente diferente de excluir crianças judias de um espaço escolar. Isto é, manter a discriminação "confinada dentro da esfera social, quando é legítima, e impedir que passe para a esfera política e pessoal, quando é destrutiva.” (ARENDT, 2004, p.274). E discriminação dentro da esfera social, para Arendt (2004, p.275), nada mais é do que o direito à livre-associação.

Então, como combater as normas e as fórmulas? Por que não começar com ações simples, como a organização espacial das salas de aula?

Sara: Antigamente, eles ficavam assim, em fila... mesmo sendo oito alunos, ficavam um na frente, um atrás, um na frente, um atrás, um na frente, um atrás. $E$ aí, a gente trocou por círculo, porque o aluno de trás perguntava, o da frente não sabia o que tava perguntando... porque o ouvinte, se o de trás fala, o da frente tá escutando, né?! E o Surdo não. Ele... ele se perdia um pouco na movimentação da comunicação dentro da própria sala. Então, quando a gente trouxe pro círculo, pras carteiras em círculo, achei que foi super bacana, pro aluno acompanhar as questões que os colegas faziam para o seu, pro professor, conseguia, assim, uma visualização melhor.

E a sala de aula em círculo não seria um ganho para todos? Por que não ampliar e adotar em todas as escolas? Por uma questão de economia? E a experiência que Sara teve em sua infância não foi importante para essa percepção? - Cabem menos alunos em uma sala com as mesas em círculos. Por uma necessidade de controle? - Com todos olhando para a frente, estabelece-se uma hierarquia espacial. Por que as fileiras foram convertidas em norma? - Porque todo mundo faz assim. Por que dependemos dessa falsa ordem social que não vive sem a perseguição? 
Como nos lembram Adorno e Horkheimer (1985, p.140), “a perseguição em geral, não se pode separar de semelhante ordem. Sua essência, por mais que se esconda às vezes, é a violência que hoje se manifesta". Sim, violência, porque mentira manifesta e persistente, pautada em uma "diferença abstrata em face da maioria". (ADORNO; HORKHEIMER, 1985, p.171).

Quando há o reconhecimento da cultura Surda, e quando há uma interferência dessa cultura sobre os educadores ouvintes que estão nas EMEBS, quebra-se a paranoia. "O próprio esclarecimento, em plena posse de si mesmo e transformando-se em violência, conseguiria romper os limites de esclarecimento.” (ADORNO; HORKHEIMER, 1985, p.171)

Violência: e o meu direito, como ouvinte, de falar? Como se sente aquele que se vê impedido de utilizar a sua forma de comunicação natural? E como essa sujeição à violência me transforma, ou não? Seria isso a "plena posse de si mesmo"? E como construir uma educação efetivamente livre de violência? Uma educação que não represente um monumento invisível e que não seja um fardo. Aceitando a diversidade - negros, brancos, pessoas de origem asiática ou indígena, pessoas com surdocegueira, entre outros - e também a pluralidade de seres únicos, que se identificam de forma complexa, que têm gostos pessoais e que trazem histórias, percursos e desejos individuais. E essa aceitação, face a uma sociedade que busca impossibilitar o pensamento e o deslocamento, que se impõe como "compulsão duradoura e organizada" (ADORNO; HORKHEIMER, 1985, p.150), não é pouca coisa.

Quando Adorno e Horkheimer pensam sobre a passagem da mimese refletora para a reflexão controlada, realizada a partir da constituição do ego que está presa a uma "pedagogia que desacostuma as crianças de serem infantis", e afirmam que a "educação social e individual reforça nos homens seu comportamento objetivamente enquanto trabalhadores e impede-os de se perderem nas flutuações da natureza ambiente" (ADORNO; HORKHEIMER, 1985, p.149), mostravam o que deveria ser combatido. Essa discussão é uma aposta na possibilidade da elaboração de uma educação emancipadora, que forma sujeitos capazes de lutar pelos seus direitos. Mais do que isso, é a proposição de uma reflexão para a mudança. Se assim não fosse, por que eles despenderiam tanto tempo para pensar sobre a sociedade moderna?

Ao analisarem a Juventude Hitlerista, Adorno e Horkheimer (1985, p.24) viram "a realização pelos iguais da igualdade do direito à injustiça". Com a chegada das pessoas com surdocegueira às escolas da RME, vemos a realização, pelos diferentes, da igualdade do direito à justiça. E a dominação pelos conceitos, materializados em uma sociedade injusta, pode ser minada quando a presença real rompe os preconceitos. 
A ciência é repetição, aprimorada como regularidade observada e conservada em estereótipos. A fórmula matemática é uma regressão conscientemente manipulada, como já o era o rito mágico, é a mais sublime modalidade do mimetismo. A técnica efetua a adaptação ao inanimado a serviço da autoconservação, não mais como magia, por meio da imitação corporal da natureza externa, mas através da automatização dos processos espirituais, isto é, através de sua transformação em processos cegos. Com seu triunfo, as manifestações humanas tornam-se ao mesmo tempo controláveis e compulsivas. Da assimilação à natureza resta apenas o enrijecimento contra ela. Hoje, a coloração destinada a proteger e a repelir é a dominação cega da natureza, que é idêntica à funcionalidade prognosticada. (ADORNO; HORKHEIMER, 1985, p.150)

Romper os preconceitos e criar novos conceitos, para fugir da repetição e quebrar os estereótipos. As antigas técnicas e as antigas metodologias, alicerçadas na norma, deixam de funcionar quando a diversidade e a pluralidade são acolhidas - e acolher não é simplesmente ocupar o mesmo espaço. Sem a automatização dos processos espirituais, sua transformação em processos cegos cessa. A imitação deixa de funcionar. E isso é violência, porque exige a posse de si mesmo e porque, após uma vida a serviço da autoconservação e da fuga da reflexão, traz à tona antigos medos.

Quando um aluno, ou uma aluna, exige o estabelecimento de vínculos para fruir o mundo, traz de volta "os gestos contagiosos dos contatos diretos reprimidos pela civilização: tocar, aconchegar-se, aplacar, induzir”. (ADORNO; HORKHEIMER, 1985, p.149) As manifestações humanas deixam de ser controláveis e compulsivas. A histeria orquestrada perde seu carisma (ADORNO; HORKHEIMER, 1985, p.152), porque a mentira manifesta perdeu a persistência; sinal de que o monumento começou a ruir: a escola como espaço de formação de mão de obra para o trabalho, não mais satisfaz. É neste ponto que vemos a importância da inclusão de alunos com surdocegueira: na possibilidade de transformação, de libertação da mentalidade do ticket.

Lia: Queria fazer só mais uma pergunta... é, com relação. Ok. Na verdade, então, não é o primeiro caso de inclusão. Como você falou, não foi o primeiro caso de inclusão, mas então, o que que a chegada do Fábio, a entrada dele na escola deu para a escola. Porque a gente pensa muito "ah, o aluno vai ganhar isso, vai fazer aquilo..." e o foco acaba sendo: "vai ser bom pra ele". Mas sempre tem algumas questões que a gente fala. É uma troca, né?! E a chegada dele, o que que marcou, o que que modificou ou não modificou, ou... não sei. O que que você pode pensar, assim, nesse sentido?

Sara: Olha. Eu posso te falar assim, com toda certeza e com toda convicção. A chegada dele, porque apesar dos outros alunos serem surdocegos, a gente ter desc... nossa, nós descobrimos que a gente já atendia surdocego. Mas não... eles 
tinham visão. Assim, uma... baixa visão, mas eles tinham visão, então não se usava braile, etc. etc. A chegada do Fábio, dentro da escola, ela trouxe, primeiro, a vontade, que despertou nos professores, de ir atrás de um conhecimento que eles não tinham... e isso estar disponível através da [nome da instituição], que foi bárbaro. Então, tá. Mas, despertou. Despertou: "Opa, a gente não sabe tudo. Lembra que a gente sabia tudo? Então, a gente não sabe não'”. Então, teve um grupo, que foi um grupo, vai, de dois, três, que foram os primeiros que foram atrás, e... como isso trouxe uma valorização muito grande pra eles, eles foram... eles tiveram seguidores, sabe?! Então tudo isso, assim, a busca do conhecimento, a visibilidade que a escola teve, em eventos, na televisão [...] Quer dizer, a valorização da escola como uma escola que tinha a possibilidade de ensinar um aluno surdocego. [...] Por exemplo, alguns eventos, assim, que tinha normalmente na escola, a chegada do Fábio trouxe adultos surdocegos, pra visita, por exemplo. A festa junina, coisas que só tinha surdo antes, passou a ter o surdocego que não era aluno. Que era de... assim... é, de associações, e lideranças, né?! E... então, trouxe pra escola essa liderança da surdocegueira, porque esse espaço também é um espaço do surdocego. Então acho que quando eles, a liderança das associações dos surdocegos entraram na escola, eu acho que trouxe um ganho muito grande pra escola. Eu acho também que, assim, o fato do Fábio ter correspondido também ao que os, todo o trabalho que os professores estavam fazendo com ele, tanto de materiais, quanto de aprendizagem de Libras tátil, ele correspondeu com muita... com muito entusiasmo, e eu acho que deu uma vida nova, assim, pra escola. "Nossa! É possível. É... não é... a gente... uma coisa que a gente achou que fosse muito difícil, na verdade não é tão difícil assim. A gente conseguiu." Sabe aquela sensação de... vitória, né, entre os professores, né, isso eu acho que foi muito bom. Mudou também a questão de todos os professores... todos não, mas aqueles que se identificaram com a surdocegueira até solicitarem: "não tem aluno surdocego pra matricular?” Sabe? [...] A grande mudança: o surdocego passou a ser bem vindo. Eu acho que essa é, essa é a resposta, assim. Essa foi a grande mudança. Ele, num primeiro momento, não se podia nem se pensar em atender. E, quando eu me aposentei, eu tive... assim, eu assisti isso. Eu vivi pra assistir isso: o surdocego passou a ser bem vindo na escola. Eu acho que isso foi, assim, uma vitória dos professores, da coordenação e da direção. 
Houve conflito, houve dificuldades, houve rechaço, houve discussão e insatisfação. Mas também houve a garantia de direitos, houve acolhimento, houve respeito e, principalmente, responsabilidade coletiva.

Quando pessoas adultas com surdocegueira também passam a ocupar a escola, a estar nos eventos, a responsabilidade coletiva se amplia. Quando pessoas adultas, profissionais da saúde, dialogam com a escola, a responsabilidade coletiva se amplia. Mas quando pessoas adultas assumem: "a gente não sabe tudo" e buscam estabelecer essa rede dialógica com outros adultos, formando uma teia de relações com o interesse comum de acolher todo e qualquer aluno, o monumento invisível mostra sua fragilidade. Vemos que ele pode ser abandonado, porque ele não é necessário. Mas ainda há muito a se fazer. Sobre a concepção de educação para Adorno, ela deve ser para a autonomia, para a emancipação, para a experiência e para a contradição:

A educação para a autonomia diz respeito a não 'entrar no jogo dos outros'; implica saber as intenções dos outros que nos convertem em objeto de seus desejos e de suas intenções reificantes. A educação para a emancipação se refere à consciência de que a estrutura da sociedade é anacrônica e que a identificação do opressor, que nos faz submissos e ao mesmo tempo desejosos de ocupar o seu lugar, seja superada. A educação para a experiência deve propiciar a superação da socialização burguesa, cuja realização significa alienação radical, isto é, apartamento extremo dos demais indivíduos A educação para a contradição deve mover a consciência em direção às necessárias contradições produzidas pela sociedade e para o entendimento de que elas não são falhas lógicas, mas têm real existência. [grifo nosso] (Crochík et al., 2013, p.19)

Então, como poderíamos deixar esse monumento? Como se daria um efetivo combate à violência? Pela consciência. Saber que os ouvintes desejam surdos ou pessoas com surdocegueira "falantes" - e aqui, cabe novamente o "s" minúsculo - e não entrar nesse "jogo". Saber que, ao perceber nos ouvintes um opressor, não cabe aos Surdos e às pessoas com surdocegueira impor, como uma reação, a identificação de todas as pessoas com deficiência auditiva como Surdos, nem a obrigatoriedade do aprendizado da Libras por toda a população brasileira. Saber que estar com ouvintes e videntes nos espaços públicos, ou mesmo nas escolas, sem nenhuma forma de intercâmbio cultural, não significa ter uma experiência inclusiva - isso seria apenas um local de permanência conjunta de pessoas apartadas, um outro exemplo de socialização burguesa. Saber que é necessário compreender onde as contradições da sociedade se objetivam, para combatê-las - a título de exemplo, poderíamos afirmar: saber que a escola pública deve ser um local de formação de e para todas as pessoas, inclusive para aqueles que almejam vagas em universidades, e que não, ela não é uma punição para os filhos de políticos - como foi possível notar que muitas pessoas a enxergam (EMI, 2014, s/p). 
Quando a educação mantém o respeito à diversidade e à pluralidade, dá-se um passo rumo à não violência. Quando ela é pública, dá-se um passo rumo à consolidação da democracia. Porém, não somos ingênuos e podemos trazer as palavras utilizadas por Adorno para encerrar sua conversa com Becker em "Educação e Emancipação":

[...] o fenômeno de que, justamente quando é grande a ânsia de transformar, a repressão se torna muito fácil; que as tentativas de transformar efetivamente o nosso mundo em um aspecto específico qualquer imediatamente são submetidas à potência avassaladora do existente e parecem condenadas à impotência. Aquele que quer transformar provavelmente só poderá fazê-lo na medida em que converter esta impotência, ela mesma, juntamente com a sua própria impotência, em um momento daquilo que ele pensa e talvez também daquilo que ele faz. (ADORNO, 1995, p.185)

Justamente quando a ânsia de transformar emerge, a mentalidade do ticket se revolta contra o risco de rompimento da (falsa) universalidade existente. E por isso, para que se estabeleça uma educação que busque a formação de sujeitos autônomos, únicos e livres, e um cenário efetivamente democrático, marcado pelo respeito à diversidade e à pluralidade, a luta continua. 


\section{CONSIDERAÇÕES FINAIS}

A presente dissertação propôs uma reflexão sobre a inclusão de alunos com surdocegueira na Rede Municipal de Ensino de São Paulo, tendo como foco as EMEBS e, como fonte, os relatos orais - histórias de vida - de profissionais que atuam ou atuaram nessas unidades. Os critérios para a escolha dos colaboradores foram: conhecimento de Libras, atuação direta ou indireta na inclusão de alunos com surdocegueira e o interesse em contribuir, voluntariamente, com o presente estudo. A partir desses relatos, foram desenvolvidas discussões que tiveram como base teórica as obras de Arendt, Adorno e Horkheimer.

Iniciamos o trabalho apresentando rapidamente o cenário da Rede Municipal de Ensino de São Paulo, com um posicionamento consonante com a perspectiva inclusiva. Realizamos um levantamento das teses e dissertações sobre a questão ou que, ao menos, fizessem menção a esse público. Parte desse levantamento - especificamente do Banco de Teses USP - foi tabulado e é apresentado ao final deste trabalho (Apêndice III).

A partir dessa introdução que buscou apresentar um panorama educacional mais geral, desenvolvemos o primeiro capítulo, A Educação de Pessoas com Surdocegueira, onde resgatamos informações históricas mais pontuais sobre a educação desse público em específico na cidade de São Paulo e municípios vizinhos. Sendo as EMEBS as unidades estudadas, trouxemos informações sobre a estruturação das mesmas e sobre a educação de Surdos, para que fosse possível pensarmos sobre o motivo dessas unidades terem sido escolhidas para acolher os alunos com surdocegueira.

O segundo capítulo, Educação em Tempos de Semiformação, apresentamos as referências teóricas que deram base para as discussões que foram aprofundadas no último capítulo. Buscamos dar ênfase à importância da comunicação e à sua relação com a rejeição à violência, pois quando comunicamos algo a alguém, ligamo-nos ao que temos em comum com esse alguém, e a forma como o fazemos, reflete e dá forma aos nossos pensamentos. Nesse sentido, o cuidado com as palavras e os termos utilizados não é puro modismo teórico. Indica uma reflexão necessária sobre os relacionamentos humanos, porque a comunicação somente se efetiva quando é uma ação comum.

No terceiro capítulo, abordamos O Método. Nele, já foi possível compreender a importância de um dos objetivos específicos propostos: trazer elementos das narrativas sobre as histórias de vida das colaboradoras que participaram da pesquisa e sobre a sua atuação profissional, 
principalmente na EMEBS. Por se tratar de um estudo qualitativo envolvendo pessoas, o cuidado com os procedimentos éticos e de análise foram valorizados no desenvolvimento deste trabalho.

Ainda sobre o método, devemos lembrar que, ao optarmos por realizar entrevistas em áudio, portanto gravações orais, não havíamos previsto que uma gravação em vídeo poderia ter sido muito mais rica - teríamos as falas e as imagens. Isto porque, apesar de todas as colaboradoras serem ouvintes, elas comunicavam algumas palavras ou expressavam pequenos detalhes em Libras, ou mesmo com gestos naturais e expressões faciais. Ester, pelo convívio mais próximo com a Comunidade Surda, parece utilizar uma Libras oralizada. Isto é, em diferentes momentos, ela fala, mas segue a estrutura gramatical da Libras. Para não perder os sinais que eram feitos, fizemos algumas intervenções orais durante as entrevistas, ou anotações por escrito, nas transcrições. Porém, não foi possível alterar a forma da coleta para que se mantivesse o mesmo padrão para todas as entrevistadas e devido às limitações técnicas desta pesquisa - equipamento disponível para a realização da mesma.

É interessante registrar, ainda, como essa influência da Libras perdura também nas profissionais que já não estão mais nas EMEBS. Em alguns momentos, elas não falavam e somente faziam o sinal, cabendo à entrevistadora "falar" o que estava vendo, para que a informação não se perdesse na gravação. Isto mostra como o aspecto cultural é potente. As influências são mútuas. Ouvintes no mundo dos Surdos também saem modificados. Este é um tema que merece ser aprofundado, mas que apenas pontuamos e deixamos como possibilidade para estudos futuros.

A discussão teórica e a análise das entrevistas foi realizada no quarto capítulo Um Monumento Invisível, que por ser mais extenso, foi dividido em três partes. Na primeira, apresentamos e destacamos elementos das narrativas sobre as histórias de vida das colaboradoras que participaram da pesquisa e sobre a sua atuação profissional, principalmente na EMEBS. Buscamos registrar desde as próprias experiências educacionais dessas educadoras na infância, com modelos positivos que elas trazem em seu repertório, até as experiências profissionais em um contexto de crise - porque de mudanças e de questionamento das antigas respostas. A própria transformação das EMEE em EMEBS, mostrou-se como a objetivação de uma resposta nova, livre das repetições e da perpetuação da história única, da versão do ouvinte - e devemos ressaltar o fato de ter sido uma conquista resultante das lutas da Comunidade Surda, com participação ativa de Surdos, o que reforça a importância da manutenção de um diálogo com essa comunidade, porque eles podem nos auxiliar na construção de novas respostas. 
Na segunda parte do capítulo Um Monumento Invisível, ao pensarmos sobre a emancipação e a inclusão a partir dos relatos de nossas colaboradoras, sintetizamos o olhar delas frente ao exercício de sua profissão em quatro eixos-palavras: direito, acolhimento, respeito e responsabilidade. Dessa forma, foi possível compreender qual o objetivo da educação para essas quatro profissionais e como essas concepções funcionaram de forma complementar.

Acreditamos que a própria decisão de atuar com alunos Surdos implica na capacidade de enxergar a educação para além da semiformação socializada. Portanto, a EMEBS foi um espaço propício para a inclusão de alunos com surdocegueira também por contar com educadores que, mesmo formados em uma sociedade que continua presa à ideia da normalidade, têm uma ação que supera esse discurso. Mais do que isso, podemos arriscar a seguinte afirmação: a escolha de pessoas que atuam ou atuaram no processo de inclusão de alunos com surdocegueira, levou-nos ao encontro de pessoas que valorizam princípios democráticos, seja por meio legal, social, teórico ou prático.

Durante a formação da rede de colaboradores, na busca de voluntários para esta pesquisa, pensamos em mudar esse critério - pessoas que atuam ou atuaram no processo de inclusão de alunos com surdocegueira. Procuramos, também, professores dessas unidades educacionais que não tivessem realizado as especializações em deficiência múltipla e surdocegueira, e que não tivessem atuado diretamente com esses alunos. Interessava-nos ouvir esses adultos que apenas tivessem visto e acompanhado esse processo, sem intervir diretamente no mesmo. No entanto, quando conversamos com algumas dessas pessoas, ao compreenderem meu projeto, automaticamente indicavam algum colega que já atuou ou que atua com alunos com surdocegueira ou deficiência múltipla. Por maior que fosse a insistência, era como se essas pessoas não se sentissem autorizadas a falar sobre essas experiências.

Por outro lado, as educadoras que buscaram essas formações como guias-intérpretes ou que atuaram, de alguma forma, nessa ação inclusiva, mostraram-se dispostas e com vontade de compartilhar e falar sobre essa temática. Das quatro pessoas entrevistadas, apenas não participou de toda a formação em surdocegueira - realizada na instituição conveniada à RME -, a coordenadora Lídia. Porém, tanto em JEIF como em ações da SME, ela também recebeu formação específica sobre surdocegueira.

O que importa pensarmos é que, mesmo sem a distância temporal e mesmo sem a distância espacial, o encontro com uma nova cultura e o novo parecem ser inspirações para o resgate da faculdade de intercambiar experiências - que Benjamin (1993, p.198) afirmava que parecia que já estávamos privados de, já no século passado. Preocupados com nossa autoconservação, raras vezes temos alguma história que consideramos relevante para ser compartilhada. 
As obrigações ocupam nosso tempo, junto com o consumo, incluindo o lazer e o entretenimento. Nada disso nos inspira a falar, mas condizem com a realidade de posts em redes sociais - e provavelmente é por isso que estas têm ganhado tanta importância.

Porém, acreditamos que a narrativa é um dom latente, inerente a todos os seres humanos, à espera de uma experiência para aflorar. Para exemplificarmos essa necessidade de narrar, contar ou mesmo denunciar, recuperamos um trecho de Euclides da Cunha.

E em toda a parte - a partir de Contendas - em cada parede branca de qualquer vivenda mais apresentável, aparecendo rara entre os casebres de taipa, se abria uma página de protestos infernais. Cada ferido, ao passar, nelas deixava, a riscos de carvão, um reflexo das agruras que o alanceavam, liberrimamente, acobertando-se no anonimato comum. A mão de ferro do exército ali se espalmara, traçando em caracteres enormes o entrecho do drama; fotografando, exata, naquelas grandes placas, o fácies tremendo da luta em inscrições lapidares, numa grafia bronca, onde se colhia em flagrante o sentir dos que o haviam gravado.

Sem a preocupação da forma, sem fantasias enganadoras, aqueles cronistas rudes deixavam por ali, indelével, o esboço real do maior escândalo da nossa história - mas brutalmente, ferozmente, em pasquinadas incríveis - libelos brutos, em que se casavam pornografias revoltantes e desesperanças fundas, sem uma frase varonil e digna. A onda escura de rancores que rolava na estrada chofrava aqueles muros, entrava pelas casas dentro, afogava as paredes até ao teto...

A comitiva, penetrando-as, repousava envolta num coro silencioso de impropérios e pragas. Versos cambeteantes, ricaços de rimas duras, enfeixando torpezas incríveis na moldura de desenhos pavorosos; imprecações revoluteando pelos cantos numa coréia fantástica de letras tumultuárias, em que caíam, violentamente, pontos de admiração rígidos como estocadas de sabre; vivas! morras! Saltando por toda a banda em cima de nomes ilustres, infamando-os, esbarrando-se discordes; trocadilhos ferinos; convícios desfibradores; alusões atrevidas; zombarias lôbregas de caserna...

E a empresa perdia repentinamente a feição heroica, sem brilho, sem altitude. Os narradores futuros tentariam em vão velá-la em descrições gloriosas. Teriam em cada página, indestrutíveis, aqueles palimpsestos ultrajantes. (CUNHA, 1982, p.373)

Trazemos esse republicano, colaborador do jornal Província de São Paulo, que foi enviado para cobrir a campanha contra os rebeldes, porque ele nos fala sobre esses registros que se tornaram necessários: em cada parede, a riscos de carvão, numa grafia bronca, em Canudos. Era o ano de 1897. Os tempos eram outros. Então, o incêndio num sótão não era mais importante que uma revolução. Ao menos neste caso, que encontrou, nessa testemunha, uma narrativa que foi publicada cerca de quatro anos depois, em Os Sertões. Segundo Caldeira (2015, p.203):

o editorialista Euclides da Cunha partira para Canudos defendendo a ação do Estado soberano contra rebeldes, o repórter vira outro mundo e agora o escritor descrevia Canudos como um atentado contra cidadãos que já não tinham voz, mas cujos cadáveres falavam por suas palavras.

Euclides evidencia um caminho inverso do anunciado por Benjamin: um jornalista acostumado com um estilo literário informativo, ainda em formação no Brasil, é atingido e transformado pela vivência de algo incomunicável, como no caso dos veteranos de guerra, mas que 
ele, como um espectador, sente a necessidade de narrar, resgatando os registros apagados daqueles palimpsestos ${ }^{87}$.

E se ele não o tivesse feito? Teríamos uma versão única. A que foi publicada nos jornais.

E se não tivéssemos escolhido escrever sobre a inclusão de alunos com surdocegueira? Afinal, conforme a apresentação desta pesquisa, o tema inicial era o processo de adoecimento e pedidos de exoneração de professores da rede pública municipal.

Quando pensamos na escola pública brasileira, vemos inúmeras narrativas e afirmações sobre o fracasso, sobre a má formação dos professores e sobre os problemas dessa instituição. Sim, os problemas são reais. Certamente, há pontos a melhorar e há aspectos objetivos e materiais que impedem o bom funcionamento de várias unidades educacionais. Mas há o predomínio de uma única versão: a do fracasso.

Neste trabalho, optamos por uma outra história, registrada em movimentos no ar, na mão sobre a mão, na atenção daquele que estende o braço e guia, no cuidado daquele que procura estabelecer uma comunicação, mesmo que essa não seja a sua forma de comunicação. Não há carvão. O material é tátil: barbante para dar volume às linhas, ou EVA. E estes registros são pessoais. É do aluno. Como afirma Ester: "os livros e os cadernos, foram com ele embora". Assim como todos os alunos fazem.

Durante nossa atuação na rede pública, testemunhamos muitas possibilidades que só podem ser encontradas nesse espaço: na educação gratuita, em uma escola para todos e para todas. Nesse sentido, o discurso sobre o fracasso nos parece tendencioso, principalmente no atual cenário de precarização das carreiras do magistério.

Em que medida isto não estaria relacionado ao interesse na preservação de privilégios e a uma segregação perigosa, porque invadindo as esferas política e pessoal? O discurso do fracasso faz com que as pessoas permaneçam presas em respostas privadas, como o pagamento de uma escola particular, porque "a escola pública não é boa”. E estas respostas privadas são respostas novas, mas são do tipo desastrosas, como Arendt (2011, p.223) previu: “Uma crise só se torna um desastre quando respondemos a ela com juízos pré-formados, isto é, com preconceitos”. E talvez, esse desastre se deva à forma como nossa sociedade vem se constituindo.

Em sua configuração atual - e provavelmente há milênios - a sociedade não repousa em atração, em simpatia, como se supôs ideologicamente desde Aristóteles, mas na

\footnotetext{
${ }^{87}$ Fazemos referência às reflexões de Benjamin (1993, p.114-5) em seu texto "Experiência e pobreza". Ao falar dos veteranos de guerra, e sobre a baixa nas ações da experiência, ele nos lembra que "já se podia notar que os combatentes tinham voltado silenciosos do campo de batalha. Mais pobres em experiências comunicáveis, e não mais ricos". Mas Euclides não foi para a guerra como um combatente. Sua experiência não se deu na luta física. Contudo, apesar da aparente passividade, ele supera o seu papel de mero espectador para enxergar os fatos, pensar sobre eles e assumir a responsabilidade por uma nova luta. Ao escrever, comunica o que havia testemunhado.
} 
persecução dos próprios interesses frente aos interesses dos demais. Isto se sedimentou do modo mais profundo no caráter das pessoas. (ADORNO, 1995, p.134)

Os próprios interesses frente aos interesses dos demais. Uma sociedade que valoriza o mérito e o talento como justificativas para a conformação de uma estrutura social que seleciona poucos, perpetuando os privilégios que nossa Constituição se propôs a derrubar - e não espanta o fato dessa mesma Constituição ter sofrido ataques, principalmente neste último ano.

Portanto, se Euclides escreve pela denúncia desses palimpsestos ultrajantes, este trabalho se constituiu como uma necessidade de registro de "um dia bom". Sem descrições gloriosas, mas contra o predomínio das versões sobre o fracasso, contra as críticas à formação dos profissionais, e com o registro de fatos e exemplos reais, que podem contribuir para a construção de outras narrativas.

E por isso, na terceira e última parte desse capítulo intitulado Um Monumento Invisível, ao analisarmos os relatos dessas profissionais especializadas sobre a reestruturação das EMEE em EMEBS, pudemos reforçar como essa escola bilíngue está de acordo com a perspectiva inclusiva, mas com a inclusão que supera a palavra e se torna um conceito - e vale lembrar novamente que, em meio à revisão do presente texto, foi publicado o Decreto $\mathrm{n}^{\circ} 57.379$, em 13 de outubro de 2016, que "Institui no Sistema Municipal de Ensino a Política Paulistana de Educação Especial, na Perspectiva da Educação Inclusiva", e a Portaria nº 8.764, em 23 de dezembro de 2016, que regulamenta o referido decreto. Estes documentos, assim como o Decreto ${ }^{\circ}$ 51.778, de 14 de setembro de 2010, que instituiu a Política de Atendimento de Educação Especial, por meio do Programa Inclui, no âmbito da Secretaria Municipal de Educação, compreendem a EMEBS como parte de uma política inclusiva.

Importa ressaltarmos o fato da redação desse último capítulo ter sofrido imensas alterações durante a pesquisa. De uma postura inicial que compreendia a escola bilíngue como um importante espaço de passagem, passamos a enxergá-la como um espaço de direito e permanência. Isto é, um modelo que poderia ser ampliado até o ensino superior universitário, proporcionando o fortalecimento da Comunidade Surda. Sob este aspecto, apesar de utilizarmos teóricos modernos em nossas discussões, sofremos uma contaminação direta das reflexões de artistas contemporâneos que participaram da $32^{\mathrm{a}}$ Bienal de São Paulo, principalmente de Grada Kilomba, Tracey Rose, Donna Kukama e Dalton Paula. Artistas que percebemos que têm uma aproximação com as discussões teóricas sobre a descolonização, mas que dão um passo para além da independência política: descolonização das palavras; descolonização dos monumentos; descolonização dos objetos; descolonização das histórias; descolonização das identidades; enfim, Descolonização - com a inicial maiúscula. E essa discussão apareceu neste trabalho apenas 
de forma introdutória, e merece um aprofundamento que poderá ser desenvolvido em estudos futuros.

Se estamos falando de culturas, de diversidade e de singularidades, são essas as reflexões que perduram e não se encerram nestas páginas. É a partir das obras desses artistas que compreendemos que continuávamos presos à lógica da normalização-integração, como se a escola bilíngue fosse um lugar de preparo para a melhor adequação ao mundo ouvinte. No caso dos alunos com surdocegueira, a melhor adequação ao mundo ouvinte e vidente.

Assim, finalizamos esse último capítulo discutindo a formação continuada de professores e quais os tipos de especialização necessários em um cenário inclusivo, superando as distinções impostas e valorizando o distinguir-se. Isto é, o critério tem que ser claro: a escola bilíngue é uma escola para pessoas Surdas. Surdas, com maiúscula, que já explicita o fato de serem fluentes em Libras e pertencentes à Comunidade Surda. É nesse ambiente linguístico que, alunos com surdocegueira que utilizam a Libras tátil, têm uma opção importante e rica para a inclusão.

A Escola Bilíngue não é uma escola especial. Porém, como qualquer unidade da RME, nessas unidades também estão sendo incluídos alunos com deficiência. A formação continuada de professores ouvintes nas EMEBS deve focar os aspectos linguísticos e culturais da Comunidade Surda e deve abranger temas relacionados à educação de pessoas com deficiência. Além disso, outro ponto que consideramos importante é que a RME deve realizar concursos em Libras para efetivar a contratação de professores Surdos e de professoras Surdas. Para estes, a formação continuada em suas áreas específicas deve ser assegurada com a presença de intérpretes e, assim como para todos os professores da RME, as formações relacionadas às pessoas com deficiência também devem ser ofertadas, incluindo a especialização em surdocegueira e deficiência múltipla sensorial. Isto porque, mesmo em uma sala de aula com um professor regente Surdo, a presença de um aluno com surdocegueira exige um guia-intérprete, que pode ser Surdo. Portanto, vislumbramos um cenário onde a primeira língua, a língua majoritária, utilizada em todos os espaços, é efetivamente a Libras.

Por fim, reforçamos a relevância da escola bilíngue pública, que além de considerar a diversidade cultural, também acolhe a diversidade social. Isto, em um país como o Brasil, onde o IDH-D (Índice de Desenvolvimento Humano ajustado à Desigualdade) evidencia o problema da distribuição de renda, é essencial.

Com essas palavras, encerramos nossas considerações, nossa contribuição com reflexões sobre a inclusão de alunos com surdocegueira na Rede Municipal de Ensino de São Paulo, 
a partir das narrativas inspiradoras de quatro educadoras, de quatro profissionais com várias especializações, mas principalmente, especializadas em Educação. 


\section{REFERÊNCIAS}

\section{Referências Bibliográficas}

ADORNO, T. W. Educação e Emancipação. Tradução de Wolfgang Leo Maar. Rio de Janeiro: Paz e Terra, 1995. 190 p. [Textos originais de 1960-1969]

. Teoria da Semicultura. Trad. de Newton Ramos de Oliveira, Bruno Pucci e Cláudia B. Moura Abreu, com colaboração de Paula Ramos de Oliveira. Educação e Sociedade: Revista Quadrimensal de Ciência da Educação, Campinas: Papirus, Ano XVIII, nº 56, dez. 1996. p.388-411. [Original publicado em 1959] Disponível em: <adorno.planetaclix.pt/tadorno.htm>. Acesso em: 15 jun. 2014. (Paginação irregular na versão digital consultada.)

ADORNO, T. W.; HORKHEIMER, M. Dialética do esclarecimento: fragmentos filosóficos. Tradução de Guido Antonio de Almeida. Rio de Janeiro: Zahar, 1985. 224 p. [Original publicado em 1947]

AMARAL, I. A educação de estudantes portadores de surdocegueira. In: MASINI, E. F. S. (org). Do sentido... pelos sentidos... para o sentido. Niterói: Intertexto/São Paulo, Vetor, 2002, p.121-144.

AMARAL, L. A. Sobre crocodilos e avestruzes: falando de diferenças físicas, preconceitos e sua superação. In: AQUINO, J. G. (coord.) Diferenças e preconceito na escola: alternativas teóricas e práticas. São Paulo: Summus, 1998, p.11-30.

AMIRALiAn, M. L. T. (et al.) Conceituando deficiência. Revista de Saúde Pública, 2000; 34 (1): 97103.

ARENDT, H. Responsabilidade e julgamento. Tradução de Rosaura Eichenberg. São Paulo: Companhia das Letras, 2004. 376 p. [Textos originais de 1959-1975]

. A condição humana. Tradução de Roberto Raposo. $11^{\text {a }}$ ed. Rio de Janeiro: Forense Universitária, 2010. 408 p. [Original publicado em 1958]

Entre o Passado e o Futuro. Tradução de Mauro W. Barbosa. $7^{\mathrm{a}}$ ed. São Paulo: Perspectiva, 2011. 350 p. [Original publicado em 1954]

BAZON, F. V. M. As mútuas influências, família-escola, na inclusão escolar de crianças com deficiência visual. 2009. Tese (Doutorado em Educação) - Faculdade de Educação, Universidade de São Paulo, São Paulo, 2009. Disponível em: <http://www.teses.usp.br/teses/disponiveis/48/48134/tde-14122009102937/pt-br.php $\geq$. Acesso em: 17 jul. 2014.

BENEVIDES, M. V. de M. O desafio da educação para a cidadania. In: AQUINO, J. G. (coord.) Diferenças e preconceito na escola: alternativas teóricas e práticas. São Paulo: Summus, 1998, p.153-169.

BENJAMIN, W. Magia e técnica, arte e política. Tradução de Sergio Paulo Rouanet. $6^{a}$ ed. São Paulo: Brasiliense, 1993. (Obras Escolhidas I)

. Charles Baudelaire: um lírico no auge do capitalismo. Tradução de José Carlos Martins Barbosa e Hemerson Alves Baptista. $3^{a}$ ed. São Paulo: Brasiliense, 1994. (Obras Escolhidas III) 
BERSCH, R. Introdução à Tecnologia Assistiva. Porto Alegre/RS: Assistiva, Tecnologia e Educação, 2013. Disponível em: <www.assistiva.com.br \. Acesso em: 15 mar. 2015.

BOSCO, I. C. M. G.; MESQUITA, S. R. S. H.; MAIA, S. R. A educação especial na perspectiva da inclusão escolar: surdocegueira e deficiência múltipla. Brasília: Ministério da Educação, Secretaria de Educação Especial/Fortaleza: Universidade Federal do Ceará, 2010. (Coleção: A educação especial na perspectiva da inclusão escolar; 5)

BOSI, E. A Pesquisa em Memória Social. Psicologia USP, São Paulo, 4 (1/2), 1993, p.277-284.

BOURDIEU, P.; PASSERON, J.-C. A reprodução: elementos para uma teoria do sistema de ensino. Tradução de Reynaldo Bairão. $3^{\text {a }}$ ed. Petrópolis, RJ: Vozes, 2010.

BRASIL. Ministério da Educação. Parâmetros Curriculares Nacionais: Adaptações Curriculares. Secretaria de Educação Fundamental. Secretaria de Educação Especial. Brasília: MEC/SEF/SEESP, 1998.

. Ministério da Educação. Saberes e práticas da inclusão: dificuldades acentuadas de aprendizagem: deficiência múltipla. Coordenação Geral: Francisca Roseneide Furtado do Monte, Idê Borges dos Santos. $4^{\mathrm{a}}$ ed. Brasília: MEC, SEESP, 2006a. (Educação Infantil; 4). Disponível em: <http://portal.mec.gov.br/seesp/arquivos/pdf/deficienciamultipla.pdf>. Último acesso em 21 ago. 2014.

. Ministério da Educação. Saberes e práticas da inclusão: dificuldades de comunicação e sinalização: surdocegueira/múltipla deficiência sensorial. Elaboração: Fátima Ali Abdalah Abdel Cader Nascimento, Shirley Rodrigues Maia. $4^{a}$ ed. Brasília: MEC, SEESP, 2006b. Disponível em: http://portal.mec.gov.br/seesp/arquivos/pdf/surdosegueira.pdf. Último acesso em: 21 ago. 2014.

. Ministério da Educação. Saberes e práticas da inclusão: dificuldades de comunicação e sinalização: surdez. Elaboração: Daisy Maria Collet de Araujo Lima. $4^{\mathrm{a}}$ ed. Brasília: MEC, SEESP, 2006c. (Educação Infantil). Disponível em: 〈http:// http://portal.mec.gov.br/seesp/arquivos/pdf/surdez.pdf〉. Último acesso em 21 ago. 2014.

. Ministério da Educação. Política Nacional de Educação Especial na Perspectiva da Educação Inclusiva. Documento elaborado pelo Grupo de Trabalho nomeado pela Portaria $\mathrm{n}^{\circ} 555 / 2007$, prorrogada pela Portaria n ${ }^{\circ}$ 948/2007, entregue ao Ministro da Educação em 07 de janeiro de 2008. Brasília: MEC, 2008. Disponível em: <http://portal.mec.gov.br/arquivos/pdf/politicaeducespecial.pdf>. Último acesso em 18 out. 2015.

BRITO, L. F. Por uma Gramática de Línguas de Sinais. Rio de Janeiro: Tempo Brasileiro/UFRJ, Departamento de Linguística e Filologia, 1995.

BRUM, E. Pela ampliação da maioridade moral. Revista Época, 22 abr. 2013. Disponível em: <revistaepoca.globo.com>. Acesso em: 24 abr. 2013.

BUENO, B. O. O método autobiográfico e os estudos com histórias de vida de professores: a questão da subjetividade. Educação e Pesquisa, São Paulo, v.28, n.1, p.11-30, jan/jun. 2002.

BUENO, B. O. (et al.). Docência, Memória e Gênero: Estudos Alternativos sobre a Formação de Professores. Psicologia USP, São Paulo, 4 (1/2), 1993, p.299-318.

CALDEIRA, J. Os sertões, democracia e cidadania. In: Júlio de Mesquita e seu tempo: O jornal de rotativa, dança e democracia. São Paulo: Mameluco, 2015, Vol.II, p.199-211.

CALDEIRA, T. P. do R. Cidade de muros: Crime, segregação e cidadania em São Paulo. São Paulo: Ed. 34/Edusp, 2000. 
CAPOVILLA, F. C. Filosofias Educacionais em Relação ao Surdo: do Oralismo à Comunicação Total, ao Bilingüismo. Revista Brasileira de Educação Especial, Vol. 6, nº 1, 2000, p.99-116.

CAPOVILLA, F. C.; RAPHAEL, W. D. (editores). Enciclopédia da Língua de Sinais Brasileira: O Mundo do Surdo em Libras. São Paulo: (Fundação) Vitae: Fapesp: Capes: Editora da Universidade de São Paulo, 2005. Volume 8.

CARMO, E. F. (et al.). Políticas públicas de democratização do acesso ao ensino superior e estrutura básica de formação no ensino médio regular. Ver. Bras. Estud. Pedagog. (online), Brasília, v.95, n.240, p.304-327, mai/ago. 2014. Disponível em: http://www.scielo.br/pdf/rbeped/v95n240/04.pdf >. Acesso em: $17 /$ out/2016.

CASTRO, A. M. de. A avaliação da aprendizagem no contexto da inclusão de alunos com necessidades educacionais especiais na escola pública. 2007. Tese (Doutorado em Educação) - Faculdade de Educação, Universidade de São Paulo, São Paulo, 2007. Disponível em: <http://www.teses.usp.br/teses/disponiveis/48/48134/tde-17122009-111437/pt-br.php>. Acesso em: 15/mai/2014.

CORMEDI, M. A. Alicerces de significados e sentidos: a aquisição de linguagem na surdocegueira congênita. 2011. Tese (Doutorado em Psicologia e Educação) - Faculdade de Educação, Universidade de São Paulo, São Paulo, 2011.

. Referencias de currículo de programas educacionais individualizados para surdocegos congênitos e deficientes múltiplos. MASINI, E. F. S. (org). Educação e alteridade: deficiências sensoriais, surdocegueira, deficiências múltiplas. São Paulo: Vetor, 2011, p.128-154.

COSTA, M. da P. R. Orientações para Ensinar o Deficiente Auditivo a se Comunicar. Revista Brasileira de Educação Especial, Vol. 1, nº 2, Piracicaba-SP, 1994, p.93-106.

CROCHÍK, J. L. Teoria Crítica da Sociedade e Psicologia: alguns ensaios. Araraquara, SP: Junqueira \& Marin; Brasília, DF: CNPq, 2011a.

Preconceito e Inclusão. Revista do Instituto Cultural Judaico Marc Chagall, v.3, n.1 (jan-jun), 2011b, p.32-42.

CROCHÍK, J. L. (et al.) Inclusão e discriminação na educação escolar. Campinas, SP: Editora Alínea, 2013.

CUNHA, E. Os sertões. São Paulo: Abril Cultural, 1982.

EMI, L. C. Y. Juan Pablo Bonet: A obra de um dos precursores da educação de Surdos. 2011. $43 \mathrm{f}$. Trabalho de Conclusão de Curso (Especialização em Educação da Pessoa com Deficiência da Audiocomunicação - EDAC) - Centro de Pesquisa e Pós-Gradução (CPPG), Faculdades Metropolitanas Unidas (FMU), São Paulo, 2011.

A escola pública em uma cidade regida pela lógica do privado: motes para discussões e reflexões. In: ANAIS do X Colóquio internacional do LEPSI “ Crianças públicas, adultos privados" e V Congresso da RUEPSY - Rede Universitária Internacional em Educação e Psicanálise e I Congresso Brasileiro da Rede INFEIES. São Paulo: Universidade de São Paulo, 2014. (Editor: Rinaldo Voltolini). Disponível em: <http://www3.fe.usp.br/secoes/inst/novo/eventos/detalhado.asp?num=1875\&cond $=12 \&$ some $=1>$. Último acesso em: 27 out. 2016.

FAGIN, J. M. Global Influences and Resistence Within: Inclusive Practices and South Africa's Apartheid Government. 2011. Dissertação (Master of Arts) - Program in Cultural and Educational Policy Studies, Loyola University Chicago, Illinois, 2011. 
FLOOD, T. 'Food' or 'Thought'? The social model and the majority world. In: BARNES, C.; MERCER, G. (ed.). The Social Model of Disability: Europe and the Majority World. Leeds: The Disability Press, 2005, p.180-192.

GIL, T. Víctor Grippo. In: PRATES, V.; VOLZ, J. Incerteza Viva: Processos Artisticos e Pedagogicos, Caderno Ecologia e Incerteza. São Paulo: Fundação Bienal, 2016.

GOFFMAN, E. Estigma: Notas sobre a Manipulação da Identidade Deteriorada. Tradução de Márcia Bandeira de Mello Leite Nunes. $4^{a}$ ed. Rio de Janeiro: LTC, 2008. [Original publicado em 1963.]

GONZALEZ, R. K. Educação especial e processos de encaminhamento para salas de recursos: relações de gênero e cor/raça. 2013. Tese (Doutorado em Educação) - Faculdade de Educação, Universidade de São Paulo, São Paulo, 2013.

GOODSON, I. F. Dar voz ao professor: as histórias de vida dos professores e o seu desenvolvimento professional. In: NÓVOA, A. (org.). Vidas de Professores. Porto, Portugal: Porto Editora, 2000, p.6378. (Coleção Ciências da Educação)

GRIN, E. J. Construção e desconstrução das Subprefeituras na cidade de São Paulo no governo Marta Suplicy. Rev. Sociol.Polit., Curitiba, v.23, n.55, p.119-145, Set. 2015. Disponível em: <http://www.scielo.br/scielo.php?script=sci_arttext\&pid=S0104-44782015000300119\&lng=en\&nrm=iso $>$ Acesso em: 09 out. 2016.

GUARINELLO, A. C. (et al.) Surdez e letramento: pesquisa com surdos universitários de Curitiba e Florianópolis. Revista Brasileira de Educação Especial, vol.15, n.1, Marília, jan./abr. 2009, p.99-120.

HOMANS, H. Leave No-One Behind: a necessary, but not suficient slogan. Revista Perspectivas do Desenvolvimento: um enfoque multidimensional. $2^{\mathrm{a}}$ ed., Vol. 2, $\mathrm{n}^{\mathrm{o}} 2$ 2, 2014, p.7-27.

IRMEN, F.; KOLLERT, A. M. C. Langenscheidts Taschenwörterbuch Portugiesisch. Berlim/Munique/Viena/Zurique/Nova Iorque: Langenscheidt, 1995.

KELLER, H. A história da minha vida: com suas cartas (1887-1901) e um relato suplementar sobre sua educação, incluindo trechos das narrativas e cartas da professora, Anne Mansfield Sullivan, por John Albert Macy. Rio de Janeiro: José Olympio, 2008.

KOHATSU, L. N. Do lado de fora da escola especial: histórias vividas no bairro e contadas por exalunos por meio do vídeo. 2005. Tese (Doutorado) - Instituto de Psicologia, Universidade de São Paulo, São Paulo, 2005, 291p.

KOLTAI, C. Violência e indiferença: duas formas de mal-estar na cultura. Violência e mal-estar na sociedade. São Paulo em Perspectiva. Revista da Fundação Seade, v. 13, no 3, jul./set. 1999, p.76-80. Disponível em: <http://www.seade.gov.br/produtos/spp/ index.php?men=rev\&cod=3140>. Acesso em: 16 mar. 2013.

LACERDA, Cristina B. F. de. Um pouco da história das diferentes abordagens na educação dos Surdos. Cad. CEDES, Campinas, vol.19, n.46, p. 68-80, set. 1998. Disponível em: <http://www.scielo.br/scielo.php?script=sci_arttext\&pid=S0101-32621998000300007\&lng=en\&nrm=iso $>$ Acesso em: 30 mar. 2016.

A prática pedagógica mediada (também) pela língua de sinais: trabalhando com sujeitos surdos. Cad. CEDES, Campinas, vol.20, n.50, p. 70-83, abr. 2000. Disponível em: < http://www.scielo.br/pdf/\%0D/ccedes/v20n50/a06v2050.pdf>. Acesso em: 30 mar. 2016. 
. A inclusão escolar de alunos surdos: o que dizem alunos, professores e intérpretes sobre esta experiência. Cad. Cedes, Campinas, vol.26, n.69, p. 163-184, mai./ago. 2006. Disponível em: <http://www.cedes.unicamp.br>. Acesso em: 24 out. 2016.

LÜDKE, M.; ANDRÉ, M. E. D. A. Pesquisa em educação: abordagens qualitativas. São Paulo: Editora Pedagógica e Universitária (EPU), 1986.

MACFARLAND, S. Z. C. Teachers' Understanding and Implementation of Van Dijk's Learning Theory for Students who are Deaf-Blind. 1993. Tese (Doutorado em Educação Especial e Reabilitação). Estados Unidos, Arizona, 1993.

MAIA, S. R. AHIMSA - os caminhos de uma instituição na área da surdocegueira. In: MASINI, E. F. S. (org). Do sentido... pelos sentidos... para o sentido. Niterói: Intertexto/São Paulo, Vetor, 2002, p.233246.

A educação do surdocego: diretrizes básicas para pessoas não especializadas. In: MASINI, E. F. S. (org). Educação e alteridade: deficiências sensoriais, surdocegueira, deficiências múltiplas. São Paulo: Vetor, 2011, p.108-128.

. Descobrindo crianças com surdocegueira e com deficiência múltipla sensorial no brincar. In: MASINI, E. F. S. (org). Educação e alteridade: deficiências sensoriais, surdocegueira, deficiências múltiplas. São Paulo: Vetor, 2011, p.300-334.

MANZINI, E. J. Formação continuada do professor para atender à Educação Inclusiva. In: Ensaios pedagógicos. Brasília: Ministério da Educação, Secretaria de Educação Especial, 2007, p.77-84.

MARTINS, M. G. Direito à educação e acessibilidade às tecnologias de informação e comunicação por alunos com deficiência. 2010. Dissertação (Mestrado em Educação) - Faculdade de Educação, Universidade de São Paulo, São Paulo, 2010.

MARX, K. O 18 Brumário de Luís Bonaparte. Rio de Janeiro: Editorial VITÓRIA Limitada, 1956. (Biblioteca da Nova Cultura - vol. XI)

MASINI, E. F. S. (org). Educação e alteridade: deficiências sensoriais, surdocegueira, deficiências múltiplas. São Paulo: Vetor, 2011.

Do sentido... pelos sentidos... para o sentido. Niterói: Intertexto/São Paulo, Vetor, 2002.

MAZZOTTA, M. J. da S. Reflexões sobre inclusão com responsabilidade. Revista @ mbienteeducação, São Paulo, v. 1, n. 2, p.165-168, 2008.

MAZZOTTA, M. J. da S.; D'ANTINO, M. E. F. Inclusão Social de Pessoas com Deficiências e Necessidades Especiais: cultura, educação e lazer. Saúde Soc. São Paulo, v. 20, p.377-389, 2011.

MAZZOTTA, M. J. da S.; SOUSA, S. M. Z. L. Inclusão Escolar e Educação Especial: Considerações sobre a Política Educacional Brasileira. Estilos da Clínica, v.5, n.9, p.96-108, 2000.

MCINNES, J. M. A guide to planning and support for individuals who are deafblind. Toronto: University of Toronto Press, 1999.

MEIHY, J. C. S. B. Manual de História Oral. São Paulo: Edições Loyola, 2000.

Prostituição à brasileira: cinco histórias. São Paulo: Contexto, 2015. 
MEIHY, J. C. S. B. M.; RIBEIRO, S. L. S. Guia prático de história oral: para empresas, universidades, comunidades, famílias. São Paulo: Contexto, 2011.

MENDES, C. E. Os sentidos de futuro para jovens negras: pelos caminhos do Capão Redondo e Jardim Ângela periferia paulistana. 2014. Dissertação (Mestrado em Psicologia Social e do Trabalho) - Instituto de Psicologia, Universidade de São Paulo, São Paulo, 2014.

MINAYO, M. C. e SANCHES, O. Quantitativo-Qualitativo: Oposição ou Complementaridade? Cad. Saúde Públ., Rio de Janeiro, 9 (3): 239-262, jul/set, 1993. Acesso em: 23 abr 2016. Disponível em: http://www.scielo.br/pdf/csp/v9n3/02.pdf.

MORENO, A. C.; FAJARDO, V. Inclusão de alunos com deficiência intelectual cresce e desafia escolas. G1, 02/03/2013. Disponível em: http://g1.globo.com/educacao/noticia/2013/03/inclusao-de-alunoscom-deficiencia-intelectual-cresce-e-desafia-escolas.html. Acesso em: 10 jun. 2016.

NÓVOA, A. (org.) Vidas de Professores. Porto, Portugal: Porto Editora, 2000. (Coleção Ciências da Educação)

PADDEN, C.; HUMPHRIES, T. Deaf in America: Voices from a culture. Cambridge, Massachusetts/London, England: Harvard University Press, 1999.

PAULA, D. Retrato Silenciado (Silenced Portrait). [Postado em 05 de out. de 2014]. Disponível em: <http://daltonpaula.blogspot.com.br/2014/10/retrato-silenciado-silenced-portrait.html>. Acesso em: 12 jun. 2016.

POLLACK, D. The Crucial Year: a time to listen. International Journal of Audiology, Vol. 6, Issue 2, 1967, p.243-247.

PORTELLI, A. Tentando aprender um pouquinho. Algumas reflexões sobre a ética na História Oral. Proj. História, São Paulo, (15), abr. 1997, p. 13-49. Disponível em: http://revistas.pucsp.br/index.php/revph/article/viewFile/11215/8223. Acesso em: 10 nov. 2016.

RAMALHO, R. Supremo mantém lei que obriga escolas privadas a receber deficientes. G1, 09/06/2016. Disponível em: <http://g1.globo.com/educacao/noticia/2016/06/supremo-mantem-lei-que-obriga-escolas-privadas-receber-deficientes.html>. Acesso em: 09 jun. 2016.

RIBEIRO, S. L. S. Tramas e traumas: identidades em marcha. 2007. Tese (Doutorado em História Social) - Departamento de História, Faculdade de Filosofia, Letras e Ciências Humanas, Universidade de São Paulo, São Paulo, 2007.

RIBEIRO, S. L. S.; LEAL, G. K. Educação inclusiva e história oral: narrativas de professores sobre a deficiência na infância. Revista Observatório, vol.2, n¹, Jan-Abr. 2016. Disponível em: <http://revista.uft.edu.br/index.php/observatorio/article/view/1812>. Acesso em: 11 nov. 2016.

ROWLAND, W. "Nothing About Us Without Us," Some Historical Reflections on the Disability Movement in South Africa. Disability World, $\mathrm{n}^{\circ}$ 11, Nov-Dec 2001. Disponível em: <http://www.disabilityworld.org/11-12_01/i1/southafrica.shtml.> Acesso em: 05 jun. 2015.

RUFFATO, L. O Brasil hipócrita: a questão do racismo. El País, Coluna Opinião, 16 set. 2014. Disponível em: <http://brasil.elpais.com/brasil/2014/09/16/opinion/1410894019_400615.html>. Acesso em: 28 abr. 2016.

SACKS, O. W. Vendo vozes: uma viagem ao mundo dos surdos. Companhia das Letras, 1998. 
SANTOS, N. J. M. dos. A consultoria colaborativa como estratégia na formação continuada de professores sobre o AEE à pessoa com surdocegueira. 2014. Dissertação (Mestrado em Educação) - Centro de Educação, Programa de Pós-Graduação em Educação, Universidade Federal de Alagoas, Maceió, 2014.

SCHLOCHAUER, C.; LEME, M. I. da S. Aprendizagem ao longo da vida: uma condição fundamental para a carreira. ReCaPe (Revista de Carreiras e Pessoas), São Paulo, v. 02 Mai/Jun/Jul/Ago 2012, p.6272.

SCHMIDT, M. L. S. Pesquisa participante e formação ética do pesquisador na área de saúde. Ciência \& Saúde Coletiva, 13(2): 391-398, 2008, p.391-398.

SILVA, A. M. de B. ADefAV - Associação para Deficientes da Áudio Visão." In: MASINI, E. F. S. (org). Do sentido... pelos sentidos... para o sentido. Niterói: Intertexto/São Paulo, Vetor, 2002, p.223232.

SILVEIRA BUENO, J. G. Educação Especial Brasileira: integração/segregação do aluno diferente. São Paulo: EDUC, 2011. [Reúne textos datados de 1993 a 2001.]

SKLIAR, C. (org.) Atualidade na Educação Bilíngue para Surdos: interfaces entre Pedagogia e Linguística. Porto Alegre: Mediação, 2015. 2v.

SOARES, R. de A. "A história da educação do surdocego no Brasil". Toque... Mãos que falam. Ano 1, nº 1, Primavera/Verão 1999. [Periódico do Grupo Brasil.]

SOUZA, J. (et al.) Ralé brasileira: quem é e como vive. Belo Horizonte: Editora UFMG, 2009.

SOUZA, R. M. de. Que palavra que te falta? Linguística, educação e surdez. São Paulo: Martins Fontes, 1998.

TORRINHA, F. Dicionário Latino Português. Porto: Gráficos Reunidos, LDA, 1994. [Original publicado em 1937.]

VIGOTSKI, L. S. A construção do pensamento e da linguagem. São Paulo: Editora WMF Martins Fontes, 2009. (Biblioteca pedagógica)

WHETNALL, E. Deafness. British Medical Journal, February 6, Vol. 1, 5431, 1965, p.362-365.

ZANATA, E. M. Práticas pedagógicas inclusivas para alunos surdos numa perspectiva colaborativa. 2005. Tese (Doutorado em Educação Especial) - Universidade Federal de São Carlos, São Carlos, 2005.

\section{Legislação de Referência}

BRASIL. Lei Federal n ${ }^{\circ} 9.394$, de 20 de dezembro de 1996. Estabelece as diretrizes e bases da educação nacional. Disponível em: <http://www.planalto.gov.br/ccivil_03/Leis/L9394.htm>. Acesso em: 20 jul. 2014.

Decreto Federal no 3.298, de 20 de dezembro de 1999. Regulamenta a Lei no 7.853, de 24 de outubro de 1989, dispõe sobre a Política Nacional para a Integração da Pessoa Portadora de Deficiência, consolida as normas de proteção, e dá outras providências. Disponível em: <http://www.planalto.gov.br/ccivil_03/decreto/d3298.htm>. Acesso em: 20 jul. 2014. 
Lei Federal $\mathrm{n}^{\circ}$ 10.436, de 24 de abril de 2002. Dispõe sobre a Língua Brasileira de Sinais Libras e dá outras providências. DOU 25.4.2002. Disponível em: <http://www.planalto.gov.br/ ccivil_03/leis/2002/110436.htm>. Acesso em: 20 jul. 2014.

. Decreto Federal $\mathrm{n}^{\circ}$ 5.296, de 2 de dezembro de 2004. Regulamenta as Leis nos 10.048, de 8 de novembro de 2000, que dá prioridade de atendimento às pessoas que especifica, e 10.098, de 19 de dezembro de 2000, que estabelece normas gerais e critérios básicos para a promoção da acessibilidade das pessoas portadoras de deficiência ou com mobilidade reduzida, e dá outras providências. DOU 23.12.2005. Disponível em: <http://www.planalto.gov.br/ccivil_03/_ato2004-2006/2004/decreto/d5296.htm>. Acesso em: 20 jul. 2014.

. Decreto Federal $n^{\circ} 5.626$, de 2005, que regulamenta a Lei Federal no $10.436 / 02$ e o art. 18 da Lei 10.098/00.

. Lei Federal $\mathrm{n}^{\circ} 12.319$, de 1 de setembro de 2010. Regulamenta a profissão de tradutor e intérprete da Língua Brasileira de Sinais - LIBRAS. DOU 2.9.2010. Disponível em: <http://www.planalto.gov.br/ccivil_03/_Ato2007-2010/2010/Lei/L12319.htm>. Acesso em: 20 jul. 2014.

Secretaria de Direitos Humanos (SEDH). Portaria $\mathrm{n}^{\circ}$ 2344, de 3 de novembro de 2010. Faz publicar a Resolução $n^{\circ}$ 01, de 15 de outubro de 2010, do Conselho Nacional dos Direitos da Pessoa Portadora de Deficiência - CONADE, que altera dispositivos da Resolução $n^{\circ} 35$, de 06 de julho de 2005, que dispõe sobre seu Regimento Interno. DOU 5.11.2010.

SÃO PAULO. Secretaria do Governo Municipal. Lei Municipal no 13.304, de 21 de janeiro de 2002. Reconhece, no âmbito do Município de São Paulo a Língua Brasileira de Sinais, LIBRAS, como língua de instrução e meio de comunicação objetiva e de uso corrente da comunidade surda, e dá outras providências. Disponível em: <

Secretaria Municipal de Educação. Decreto n ${ }^{\circ} 45.415$, de 18 de outubro de 2004. Estabelece diretrizes para a Política de Atendimento a Crianças, Adolescentes, Jovens e Adultos com Necessidades Educacionais Especiais no Sistema Municipal de Ensino. Disponível em: <http://www.portalsme.prefeitura.sp.gov.br/documentos/edesp/decreto45415.pdf.>. Acesso em: 22 mar. 2015.

Portaria Intersecretarial no 22, de 10 de dezembro de 2004 - Secretaria Municipal de Educação, Secretaria Municipal de Assistência Social, Secretaria das Subprefeituras e o Secretaria Municipal de Saúde. Institui um Grupo Intersecretarial de Apoio a Inclusão no âmbito de cada Subprefeitura do Município de São Paulo. Disponível em: <http://www.prefeitura.sp.gov.br/cidade/secretarias/pessoa_com_deficiencia/conselho/legislacao/index.php?p=505>. Acesso em: 22 mar. 2015.

Secretaria Municipal de Educação. Portaria $n^{\circ}$ 5718, de 17 de dezembro de 2004. Dispõe sobre a regulamentação do Decreto 45.415, de 18/10/04, que estabelece diretrizes para a Política de Atendimento a Crianças, Adolescentes, Jovens e Adultos com Necessidades Educacionais Especiais no Sistema Municipal de Ensino, e dá outras providências. Disponível em: <http://portalsme.prefeitura.sp.gov.br/Documentos/BibliPed/TextosLegais/LegislacaoEducacional/Portaria_5718.pdf.>. Acesso em: 22 mar. 2015.

Secretaria Municipal de Educação. Decreto $n^{\circ}$ 45652, de 23 de dezembro de 2004. Dá nova redação a o parágrafo único do artigo $7^{\circ}$ do Decreto $n^{\circ} 45415$, de 18 de outubro de 2004 , que estabelece diretrizes para a Política de Atendimento a Crianças, Adolescentes, Jovens e Adultos com Necessidades Educacionais Especiais no Sistema Municipal de Ensino. Disponível em: <http://www3.prefeitura.sp.gov.br/cadlem/secretarias/negocios_juridicos/cadlem/integra.asp?alt=24122004D\%20456520000>. Acesso em: 22 mar. 2015.

Secretaria Municipal de Educação. Portaria $\mathrm{n}^{\circ}$ 5883, de 27 de dezembro de 2004. Altera a redação do art. 16 da Portaria SME 5718, de 17/12/04, que dispõe sobre a regulamentação do Decreto 
45.415, de 18/10/04, que estabelece diretrizes para a Política de Atendimento a Crianças, Adolescentes, Jovens e Adultos com Necessidades Educacionais Especiais no Sistema Municipal de Ensino, e dá outras providências. Disponível em: <http://www3.prefeitura.sp.gov.br/ cadlem/secretarias/negocios_juridicos/cadlem/integra.asp?alt=28122004P\%20058832004SME>. Acesso em: 22 mar. 2015.

Secretaria Municipal de Educação. Decreto n ${ }^{\circ} 51778$, de 14 de setembro de 2010. Institui a Política de Atendimento de Educação Especial, por meio do Programa Inclui, no âmbito da Secretaria Municipal de Educação e dá outras providências. Disponível em: <http://www3.prefeitura.sp.gov.br/cadlem/secretarias/negocios_juridicos/cadlem/integra.asp?alt=15092010D\%2051778 0000>. Acesso em: 20 jul. 2014.

. Secretaria do Governo Municipal. Decreto no 52785, de 10 de novembro de 2011. Cria as Escolas Municipais de Educação Bilíngue para Surdos (EMEBS) na rede municipal de ensino. Disponível em: $\quad<$ https://normain.wordpress.com/legislacao-municipal-emebs-decreto-52785-de-10-11-11/>. Acesso em: 20 jul. 2014.

Secretaria Municipal de Educação. Portaria $\mathrm{n}^{\circ}$ 5707, de 12 de dezembro de 2011. Regulamenta o Decreto 52.785 de 10/10/2011 que criou as Escolas de Educação Bilíngue para Surdos EMEBS na Rede Municipal de Ensino e dá outras providências. Disponível em: <http://www3.prefeitura.sp.gov.br/cadlem/secretarias/negocios_juridicos/cadlem/integra. asp?alt=13122011P\%200570720 11SME>. Acesso em: 20 jul. 2014.

Secretaria Municipal de Educação. Portaria $\mathrm{n}^{\circ}$ 2496, de 02 de abril de 2012. Regulamenta as salas de apoio e acompanhamento à inclusão - SAAIS, integrantes do inciso II do artigo $2^{\circ}$ - PROJETO APOIAR que compõe o Decreto $n^{\circ} 51.778$, de 14/09/10, que institui a política de atendimento de Educação Especial do Programa INCLUI, no âmbito da Secretaria Municipal de Educação de São Paulo. Disponível em: <http://portalsme.prefeitura.sp.gov.br/Projetos/supervisao/Anonimo/DOC\%202012/ P2946SAAI.htm>. Acesso em: 20 jul. 2014.

Secretaria Municipal de Educação. Portaria no 2963, de 15 de maio de 2013. Organiza o quadro de Auxiliares de Vida Escolar - AVEs e de Estagiários de Pedagogia, em apoio a Educação Inclusiva, especifica suas funções e dá outras providências. Disponível em: <http://www.portalsme.prefeitura.sp.gov.br/Documentos/BibliPed/TextosLegais/coletanea_2014_Portarias_SME.pdf>. Acesso em: 20 jul. 2014.

Secretaria Municipal de Educação. Portaria no 6542, de 26 de novembro de 2013. Dispõe sobre diretrizes, normas e períodos para a realização de matrículas na Educação Infantil, Ensino Fundamental e Educação de Jovens e Adultos - EJA, na Rede Municipal de Ensino e nas instituições privadas de Educação Infantil da Rede Indireta e Conveniada e dá outras providências. Disponível em: $<$ http://www3.prefeitura.sp.gov.br/cadlem/secretarias/negocios_juridicos/cadlem/integra.asp?alt= 27112013P\%20065422013SME>. Acesso em: 22 mar. 2015.

Secretaria Municipal de Educação. PORTARIA 3560, de 27 de junho de 2014. Estabelece procedimentos para designação para a função de professor regente de classelaulas nas Escolas Municipais de Educação Bilíngue para Surdos - EMEBS e Unidades Polo da Rede Municipal de Ensino nos casos que especifica. Disponível em: <http://www.sinesp.org.br/index.php?option=com_content\& view=article\&id=11918:portaria-no-560-de-27-de-junho-de-2014-estabelece-procedimentospara-designacao-para-a-funcao-de-professor-regente-nas-emebs-e-unidades-polo-\&catid=58:portarias\&Itemid=202>. Acesso em: 10 jul. 2015.

\section{Fontes orais (acesso restrito)}


ESTER. Entrevista I. [3 mar. 2016]. Entrevistadora: Lia Cazumi Yokoyama Emi. São Paulo, 2015. 1 arquivo .mp3 ( 2 horas, 8 minutos e 12 segundos)

LÍDIA. Entrevista I. [4 ago. 2016]. Entrevistadora: Lia Cazumi Yokoyama Emi. São Paulo, 2015. 1 arquivo .mp3 (1 hora, 20 minutos e 52 segundos)

RUTE. Entrevista I. [13 jun. 2016]. Entrevistadora: Lia Cazumi Yokoyama Emi. São Paulo, 2015. 1 arquivo .mp3 (1 hora, 12 minutos e 31 segundos)

SARA. Entrevista I. [15 out. 2015]. Entrevistadora: Lia Cazumi Yokoyama Emi. São Paulo, 2015. 1 arquivo .mp3 (1 hora, 5 minutos e 36 segundos)

SARA. Entrevista II. [13 abr. 2016]. Entrevistadora: Lia Cazumi Yokoyama Emi. São Paulo, 2015. 1 arquivo .mp3 (1 hora e 59 segundos)

\section{Fontes audiovisuais}

ADICHIE, C. The danger of a single story (O perigo de uma única história). TedGlobal. Filmado em Jul. 2009. (18 minutos e 49 segundos). Disponível em: <https://www.ted.com/talks/chimamanda_adichie_the_danger_of_a_single_story?language=pt-br>. Acesso em: 7 out. 2016.

KILOMBA, G. Dealing with Racism (Lidando com o racismo na Europa). Callings. Editor: Tychicus Vasquez.Tradução para o português: Felipe Machado. Gravação e legendagem: Chris Mckee (5 minutos e 27 segundos). Disponível em: <https://www.youtube.com/watch?v=DdpUFybJddc>. Acesso em: 10 jun. 2016. 


\section{APÊNDICE I - Termo de Consentimento Livre e Esclarecido (TCLE)}

\section{TERMO DE CONSENTIMENTO LIVRE E ESCLARECIDO}

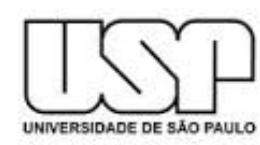

\section{Termo de Esclarecimento}

Você está sendo convidado para participar do projeto de pesquisa “A Inclusão de Alunos com Surdocegueira na Rede Municipal de Ensino de São Paulo: relatos de profissionais especializados", que será realizado através do Instituto de Psicologia (IP) da Universidade de São Paulo (USP), como parte da pesquisa de Mestrado em Psicologia Escolar e do Desenvolvimento Humano.

Estas informações estão sendo fornecidas para sua participação voluntária neste estudo, sem nenhum benefício financeiro previsto.

O objetivo geral da pesquisa é propiciar uma reflexão sobre as mudanças na educação a partir do olhar de profissionais especializados da Rede Municipal de Ensino de São Paulo. Por meio de suas Histórias de Vida, buscar-se-á compreender como os profissionais que atuam ou atuaram na Rede Municipal de Ensino passaram por essas transformações.

Sua participação acontecerá através de cerca de três encontros: duas entrevistas e um ou dois encontros para as devolutivas. A história oral de vida não tem um roteiro pré-estabelecido, mas as entrevistas serão guiadas por perguntas abertas, e o entrevistado terá total liberdade para abordar diferentes assuntos ou para interrompê-los. As entrevistas e devolutivas serão realizadas pela mestranda Lia Cazumi Yokoyama Emi, em local definido em comum acordo.

Para cada entrevista será necessário reservar um período de aproximadamente uma hora e meia, incluindo o tempo de montagem e desmontagem do equipamento de gravação. Esta será registrada em áudio e será utilizada para a transcrição em texto. Uma via da transcrição final será entregue ao voluntário, sendo a mesma rubricada e assinada. As gravações serão guardadas por um período de dois anos e estarão em posse da pesquisadora, com livre acesso por parte do voluntário.

Não há riscos diretos relacionados aos processos que serão realizados neste estudo, no entanto, de acordo com a resolução 466/12 e zelando por evitar ou minimizar qualquer situação de desconforto ou constrangimento para falar sobre qualquer parte do tema proposto, como cautela, será garantida a interrupção das entrevistas e da participação na pesquisa assim que solicitado pelo voluntário.

Não haverá identificação da(s) unidade(s) educacional(is), ficando apenas a caracterização genérica: EMEBS da cidade de São Paulo. Será garantido o anonimato, assim como o sigilo de todos os voluntários quando da divulgação dos dados em todas as fases da pesquisa. 


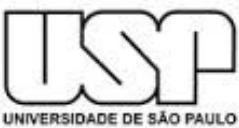

\section{Garantia de Acesso}

Os contatos para as entrevistas podem não esclarecer todas as questões e dúvidas do voluntário. Portanto, é assegurada a assistência durante toda pesquisa, bem como é garantido o livre acesso a todas as informações e esclarecimentos adicionais sobre o estudo e suas consequências antes, durante e depois da sua participação. $\mathrm{O}$ contato com a pesquisadora pode ser feito em qualquer tempo pelos dados abaixo:

Lia Cazumi Yokoyama Emi lia-emi@usp.brou liaprojs@yahoo.com.br

(55 11) 2129-6049 / (55 11) 9-9303-0499

Se você tiver alguma consideração ou dúvida sobre a ética da pesquisa, entre em contato com o Comitê de Ética em Pesquisa (CEP):

Comitê de Ética em Pesquisa com Seres Humanos do Instituto de Psicologia da USP Av. Prof. Mello Moraes, 1.721 - Bloco G, 20 andar, sala 27 CEP 05508-030 - Cidade Universitária - São Paulo/SP

E-mail: ceph.ip@usp.br Tel. (11) 3091-4182

Agendamento preferencialmente por e-mail, com a introdução do assunto. Atendimento: Das $8 \mathrm{~h} 30$ às $12 \mathrm{~h}$ e das $14 \mathrm{~h}$ às $16 \mathrm{~h}$.

É garantida a plena liberdade de não querer participar do projeto de pesquisa ou de retirar o consentimento a qualquer momento, no caso da aceitação, sem qualquer prejuízo ao voluntário. Fica assegurado que somente o pesquisador responsável e colaboradores da pesquisa terão acesso aos dados do participante e da entrevista, ficando garantidas, assim, a privacidade e a confidencialidade. 


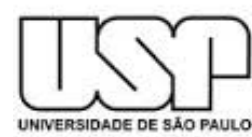

Fui suficientemente esclarecido(a) a respeito das informações sobre o estudo acima citado, que li ou que leram para mim. Ficaram claros para mim quais são os propósitos do estudo, os procedimentos a serem realizados, as garantias de confidencialidade e de esclarecimento permanentes. Ficou claro também que não há nenhum valor econômico, a receber ou a pagar, por minha participação. Concordo, voluntariamente, em participar deste estudo e poderei retirar o meu consentimento, a qualquer momento, sem penalidades ou prejuízos e sem a perda de qualquer benefício que eu possa ter adquirido. Eu receberei uma via deste Termo de Consentimento Livre e Esclarecido (TCLE) e a outra ficará com o pesquisador responsável por essa pesquisa. Além disso, estou ciente de que eu e o pesquisador responsável deveremos rubricar todas as folhas do TCLE e assinar na última folha. Assim, tendo sido orientado quanto ao teor de todo o aqui mencionado e compreendido a natureza e o objetivo do referido estudo, manifesto meu livre consentimento em participar da pesquisa.

Data: 1

Nome do voluntário da pesquisa:

Assinatura do voluntário da pesquisa:

Data:

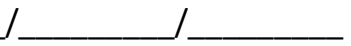

Nome do pesquisador responsável:

Assinatura do pesquisador responsável: 
APÊNDICE II - Termo de Compromisso de Utilização dos Dados (TCUD)
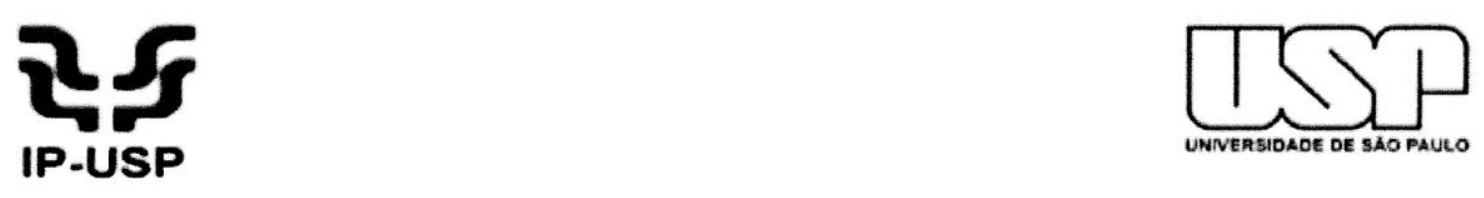

\section{TERMO DE COMPROMISSO DE UTILIZAÇÃO DE DADOS}

Nós, abaixo assinado(s), pesquisadores envolvidos no projeto de título "A Inclusão de Alunos Surdocegos na Rede Municipal de Ensino de São Paulo: relatos de profissionais especializados", nos comprometemos a:

- Garantir o respeito à dignidade humana;

- Garantir o sigilo relativo às propriedades intelectuais;

- Garantir que os benefícios resultantes do projeto retornem aos participantes da pesquisa;

- Dar início à pesquisa somente após a aprovação pelo Comitê de Ética em Pesquisa com Seres Humanos;

- Anexar todos os resultados da pesquisa na Plataforma Brasil.

São Paulo, 07 de agosto de 2015.
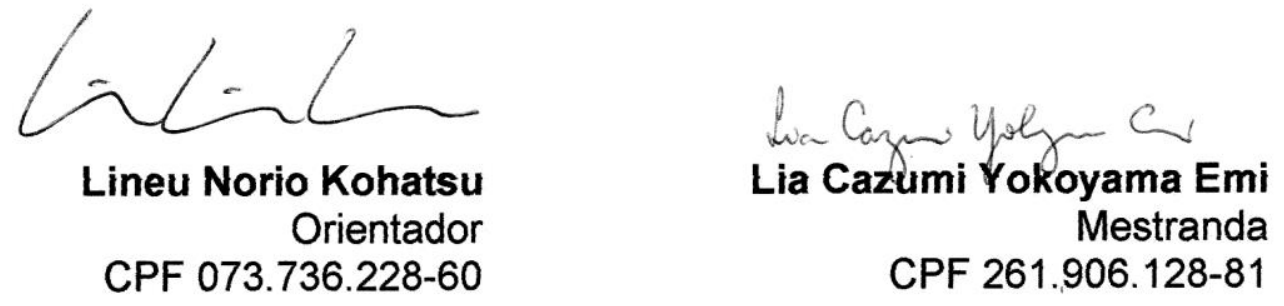
APÊNDICE III - Quadro-síntese do levantamento realizado no Banco de Teses USP 
